Historic, Archive Document

Do not assume content reflects current scientific knowledge, policies, or practices. 



\section{FOREST HABITAT}

\section{for MAMMALS}
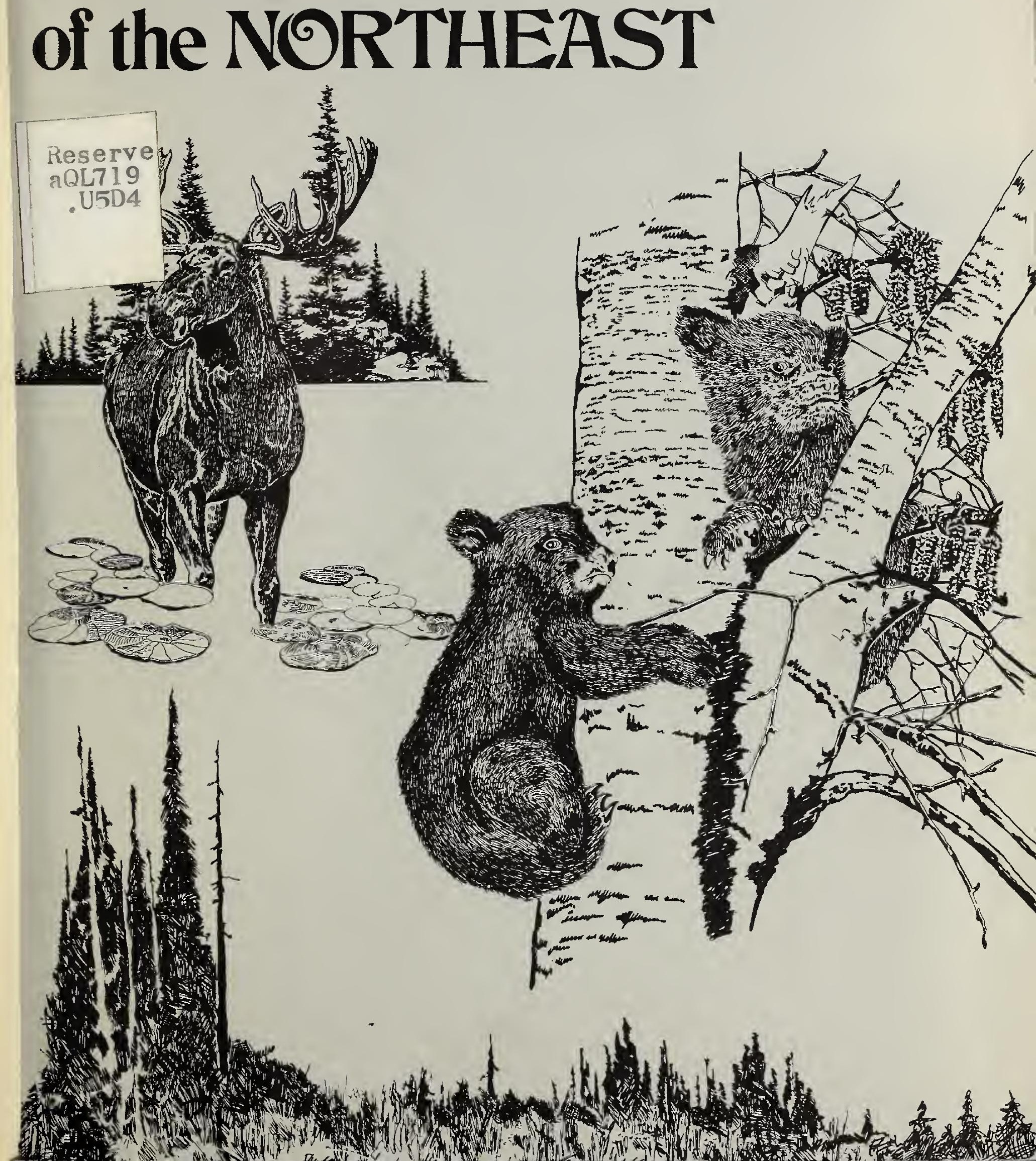
ISDA, Aationa! Agrioulural Librery

MAB E-to

to 1 asmore Blvd

Seitsula, MD $20705-2201$

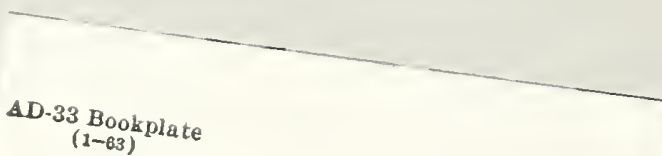

NATIONAL

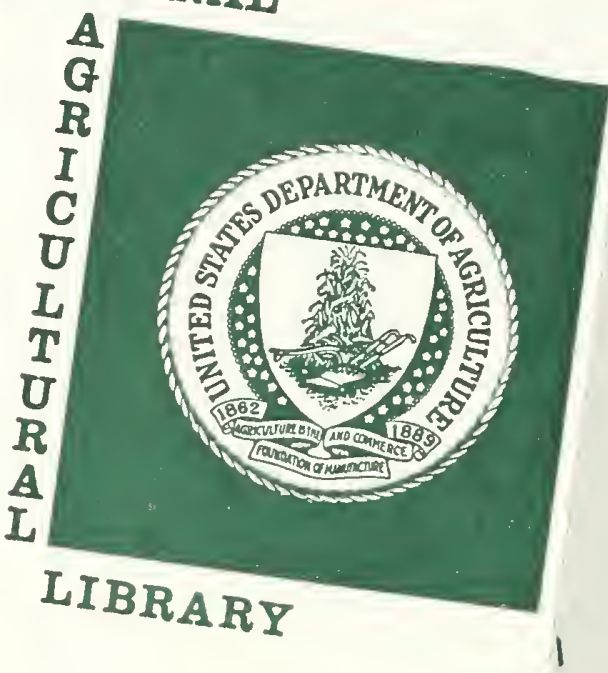




\section{FOREST HABITAT for \\ MAMMALS \\ of the \\ NORTHEAST}

by

Richard M. DeGraaf

Principal Research Wildlife Biologist Northeastern Forest Experiment Station

Amherst, Massachusetts

Gretchin M. Witman

Wildlife Tectinician

Northeastern Forest Experiment Station

Amherst, Massachusetts

\author{
Deborah D. ̊̈udis
Wildlife Technician \\ Deborah D. Rudis
Wildlife Technician
tern Forest Experimen \\ Northeastern Forest Experiment Station \\ Amherst, Massachusetts
}

U.S. DENT. OF AGRICULTURE

NATIONGL AGRICULTURAL LIBRARY

NOV -21981

CATALOGING = PREP.

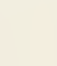




\section{ACKNOWLEDGMENTS}

We gratefully acknowledge those who helped in this work. The following willingly reviewed the manuscript draft and made many useful suggestions: Wendell E. Dodge, U. S. Fish and Wildlife Service, Edward N. Francq, University of New Hampshire, Gordon L. Kirkland, Jr., Shippensburg State College, Shippensburg, Pennsylvania, Thomas H. Kunz, Boston University, Harvey R. Smith, U. S. Forest Service, and Dana P. Snyder, University of Massachusetts. He thank Dottie McDougal and Freddie Morril1 for typing the manuscript.

Illustrations by Rosalyn A. Alexander are reprinted from MAMMALS OF ONTARIO by Anne Innis Dagg, copyright (c) 1974 by Anne Innis Dagg. Used with permission of the publisher, Otter Press, Haterloo, Ontario, Canada.

Cover art by Howard Hoffman, Forest Service, Eastern Region, Milwaukee, Wisconsin. 


\section{FOREWORD}

Sixty-five species of mammals inhabit the eight-state New England Planning Area of the Eastern Region, Forest Service, U.S. Department of Agriculture. They are distributed in characteristic groups in the various forest types of the Northeast.

The Forest Service is committed to the proper management of all wildlife resources. Mammals comprise a rich biological and recreational resource. Consideration of their habitat needs is essential for a balanced 1 and management program.

This publication provides habitat requirements for mammals associated with a forest environment. It is one of a series of four. Three oublications deal with the birds, mammals, and reptiles and amphibians of forested areas of the Northeast. The fourth provides recommendations for management. The information will assist Federal and State land management agencies, as well as orivate individuals, to plan for the habitat needs of all wildlife in the management of public and private forest lands.

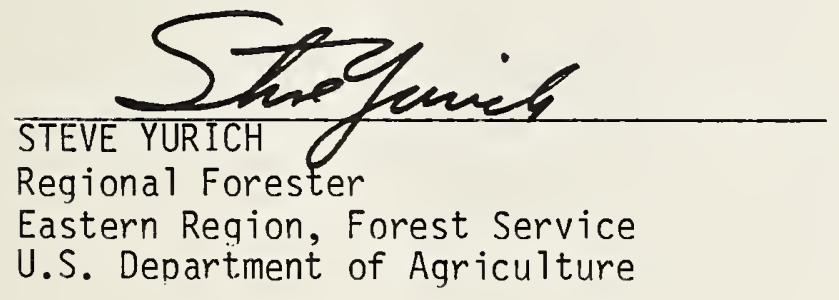




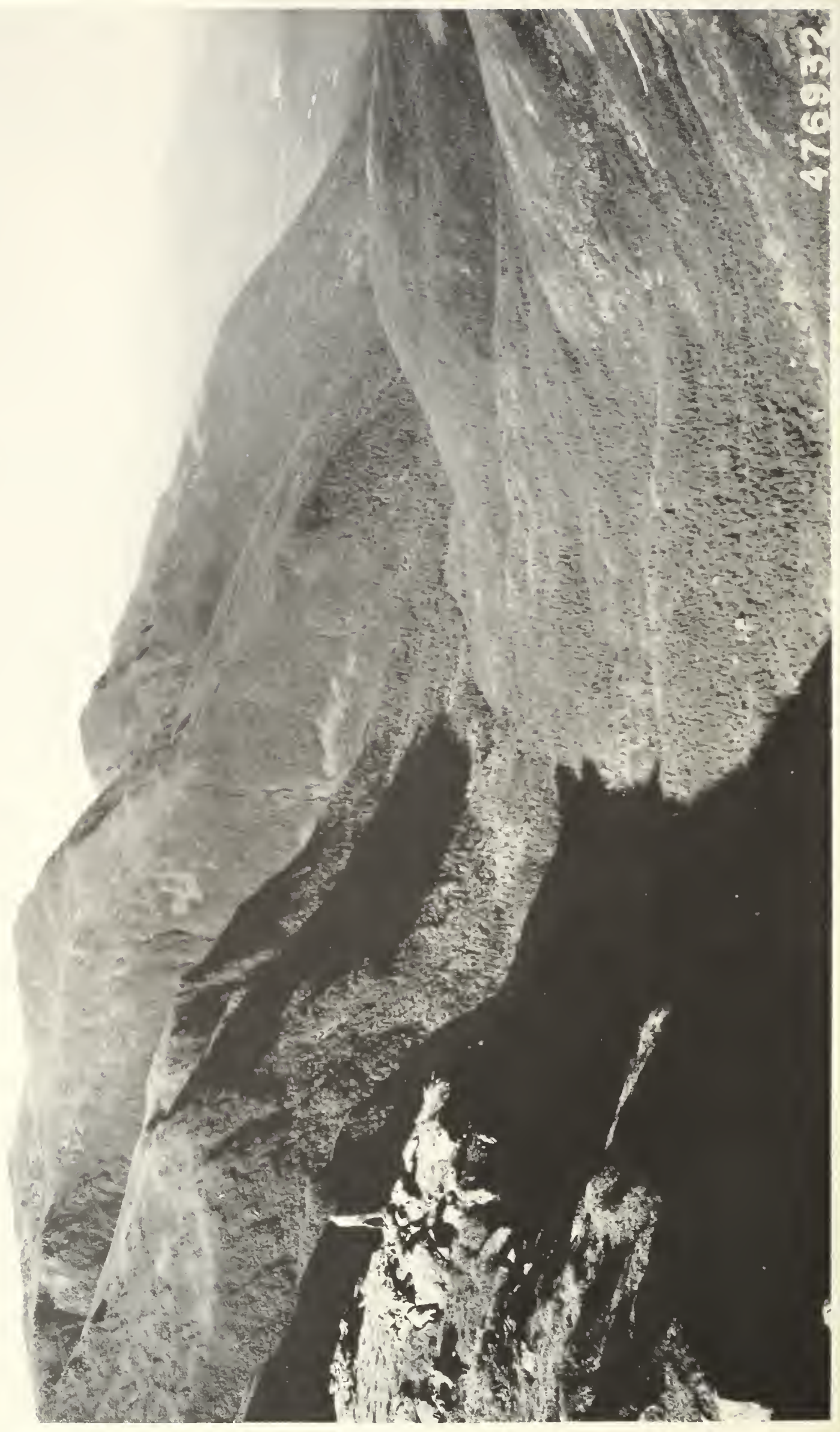




\section{TABLE OF CONTENTS}

Acknowledgments .................. . ii

Introduction .................... 1

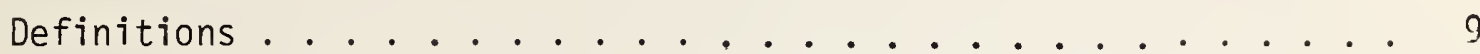

Descriptions of Community Types . . . . . . . . . . 13

Mammals of the New England Area - Species List . . . . . . . 15

Mammal Habitat Relationships Tables . . . . . . . . . . . 19

Natural History Profiles and Range Maps . . . . . . . . . . 25-154

Virginia opossum (Didelphis virginiana). . . . . . . . . 26

Masked shrew (Sorex cinereus) . . . . . . . . . . . . 28

Water shrew (Sorex palustris) . . . . . . . . . . . 30

Smoky shrew (Sorex fumeus) . . . . . . . . . . . . . . 32

Long-tailed shrew (Sorex dispar) . . . . . . . . . . . 34

Thompson's pygmy shrew (Microsorex thompsoni) . . . . . . . 36

Short-tailed shrew (Blarina brevicauda) . . . . . . . . . 38

Least shrew (Cryptotis parva) . . . . . . . . . . . . . . 40

Hairy-tailed mole (Parascalops breweri) . . . . . . . . . 42

Eastern mole (Scalopus aquaticus) ............. . 44

Star-nosed mole (Condyzura cristata) . . . . . . . . . 46

Little brown myotis (Myotis Zucifugus) . . . . . . . . . 48

Keen's myotis (Myotis keenii) .............. 50

Indiana myotis (Myotis sodalis) . . . . . . . . . . . . 52

Sma11-footed myotis (Myotis leibii) . . . . . . . . . . 54

Silver-haired bat (Lasionycteris noctivagans) . . . . . . . 55

Eastern pipistrelle (PipistrelZus subflavus) . . . . . . . 58

Big brown bat (Eptesicus fuscus) . . . . . . . . . . . . 60

Red bat (Lasiurus borealis) . . . . . . . . . . . . . 62

Hoary bat (Lasiurus cinereus) . . . . . . . . . . . . 64

Eastern cottontail (Sylvilagus floridanus) . . . . . . . . 66

New England cottontail (Sylvilagus transitionalis) . . . . . 68

Snowshoe hare (Lepus omericanus) . . . . . . . . . . . 70

Black-tailed jackrabbit (Lepus californicus) . . . . . . . . 72

European hare (Lepus europaeus) . . . . . . . . . . . . . . 74

Eastern chipmunk (Tomias striatus) . . . . . . . . . . 76

Woodchuck (Marmota monax) . . . . . . . . . . . . . . . . 78

Gray squirrel (Sciurus carolinensis) . . . . . . . . . . . 80

Red squirrel (Tomiasciurus hudsonicus) . . . . . . . . . . . 82

Southern flying squirrel (Glaucomys volans) . . . . . . . . 84

Northern flying squirrel (Glaucomys sabrinus) . . . . . . . 86

Beaver (Castor canadensis) . . . . . . . . . . . . 88 
Deer mouse (Peromyscus maniculatus) . . . . . . . . . . . . 90

White-footed mouse (Peromyscus leucopus). . . . . . . . . . . . . 92

Eastern woodrat (Neotoma floridana) . . . . . . . . . . . 94

Gapper's red-backed mouse (Clethrionomys gapperi) . . . . . . . 96

Meadow vole (Microtus pennsyzvanicus) . . . . . . . . . . . 9 98

Rock vole (Microtus chrotorrhinus). . . . . . . . . . . . 100

Pine vole (Microtus pinetorum) .. . . . . . . . . . . 102

Muskrat (Ondatra zibethicus) . . . . . . . . . . . . 104

Southern bog lemming (Synaptomys cooperi) . . . . . . . . 106

Northern bog lemming (Synaptomys borealis). . . . . . . . . 108

Black rat (Rattus rattus) . . . . . . . . . . . . . 110

Norway rat (Rattus norvegicus) . . . . . . . . . . . . 112

House mouse (Mus musculus) . . . . . . . . . . . . . . . 114

Meadow jumping mouse (Zapus hudsonius). . . . . . . . . . . 116

Woodland jumping mouse (Napaeozapus insignis) . . . . . . . . 118

Porcupine (Erethizon dorsatum) . . . . . . . . . . . . 120

Coyote (Canis Zatrans) . . . . . . . . . . . . . . . 122

Red fox (Vulpes vulpes) . . . . . . . . . . . . . . . . 124

Gray fox (Urocyon cinereoargenteus) . . . . . . . . . . . 126

Black bear (Ursus americanus) . . . . . . . . . . . . 128

Raccoon (Procyon Zotor) . . . . . . . . . . . . . . 130

Marten (Martes americana) . . . . . . . . . . . . . . . 132

Fisher (Martes pennanti) . . . . . . . . . . . . . . . 134

Ermine (Mustela erminea) . . . . . . . . . . . . . . 136

Long-tailed weasel (Mustela frenata) . . . . . . . . . . 138

Mink (Mustela vison) . . . . . . . . . . . . . . . . . 140

Striped skunk (Mephitis mephitis) . . . . . . . . . . . . . . 142

River otter (Lutra canadensis) . . . . . . . . . . . . . . . 144

Mountain Tion (Felis concolor). . . . . . . . . . . . . 146

$\operatorname{Lynx}(\operatorname{Lyn} x \operatorname{lyn} x)$. . . . . . . . . . . . . . . . . 148

Bobcat (Lynx rufus) . . . . . . . . . . . . . . . . . 150

White-tailed deer (odocoileus virginianus). . . . . . . . . 152

Moose (Alees alces)................. . 154

References . . . . . . . . . . . . . . . . 157 


\section{INTRODUCTION}

This is a guide to the habitats used by mammals in managed forests of the Northeast. Two centuries of use have greatly altered these woodlands, and forest management activities continue to be the dominant factor affecting wildlife habitats. Although no longer pristine, our northeastern forests can, with proper management, provide the full range of habitats needed by native wildlife species.

Although written specifically for the New England Planning Area of the Eastern Region of the Forest Service (Fig. 1), the information contained on the habitat associations of the included species should apply wherever the species' ranges overlap the various community (forest) types in the Northeast. Our purpose here is to assemble, from the available literature and expert review, natural history profiles and associations with forest type and age class or successional stage habitats.

These associations, presented for both timbered and non-timbered communities, will enable forest managers or wildlife biologists to describe the general mammalian fauna to be found in a given community or age class, and the species profiles can be used to find additional detailed habitat or natural history information.

Management of wildife on public land is a responsibility shared by the various States and Federal 1and management agencies. By agreement, States manage or regulate wildlife populations, and Federal agencies manage habitats. Naturally, close cooperation is required to meet wildlife management goals. This manual provides only habitat information-wildlife population goals must be developed through the coordination of activities of a11 involved agencies. 
The size, distribution, and variety of wildlife populations are functions of the amount, diversity and quality of available habitats. Wildlife management is therefore dependent upon the systematic accumulation and analysis of habitat data. Recent legislation has mandated that ecological consideration have an important part in forest management and related resource-use decisions:

1. Fish and Wi7d7ife Coordination Act (16 U.S.C. 667-666c, 1934 as amended). It seeks to protect fish and wildlife habitats by requiring the U.S. Fish and Wildlife Service and the National Marine Fisheries Service to review and report on proposed water and associated land development projects. Evaluations cover projects receiving Federal funds and those permitted under Sections 9 and 10 of the River and Harbor Act of 1899, Sections 402 and 404 of the Federal Water Pollution Control Act amendments of 1972, and other appropriate Acts.

2. Multiple Use and Sustained Yield Act of 1960 (P.L. 86517). It directs the U.S. Forest Service to consider a11 renewable resources in conjunction with one another.

3. Environmental Policy Act of 1969 (P.L. 91-190). It encourages productive harmony among man and his environment. It requires any Federalily financed project be evaluated and environmental impacts, including those on fish and wildife, and alternative opportunities be identified.

4. Endangered Species Act of 1973 (P.L. 93-205). It calls for conservation of endangered and threatened species, and of the ecosystems supporting them. Critical habitats required to assure survival and restoration of endangered species are identified, delineated, and maintained.

5. Sikes Act of 1974 (P.L. 93-452). It calls for new directions and cooperation with the States in planning and management of wildiife habitat on Federal lands.

6. Forest and Rangeland Renewable Resources Planning Act of 1974 (P.L. 93-378). It directs the U.S. Forest Service to inventory natural resources in the National Forest System and provide comprehensive plans for their management. 
7. Federal Land Policy and Management Act of 1976 (P.L. 94-579). It establishes national policy to retain rather than dispose of the National Resource Lands, and directs that those lands be inventoried, uses be planned on a multiple-use and sustained-yield basis, and that lands be managed on a sound ecological basis, with habitat provided for fish and wildlife. Land-use plans and regulations must include protection of public land areas of critical environmental concern. This means delineated areas of public lands where special management attention is required, among a broad spectrum of purposes, to protect and prevent irreparable damage to important fish and wildiife resources or other natural systems or processes. In resource inventories, priority shall be given to designation and protection of areas of critical environmental concern.

8. National Forest Management Act of 1976 (P.L. 94-588). It requires, among other things, that research be conducted to ensure that land management systems will not substantially impair land productivity.

All wildlife species are important in the functioning of communities. The key to planning the management for all species of wildlife is to know their habitat requirements and to provide them in a variety of combinations that meet the needs of as many species as possible. To be applied in managed forests, wildlife habitats need to be expressed in forest management terms.

Prescriptions are needed to modify existing standard silvicultural practices to accommodate the habitat needs of all wildlife species. This is an attempt to relate mammals to forest communities and age classes, and to provide detailed habitat information in the natural history profiles.

In addition to the few hunted species, many other mammals occur in New England forests. Although they are often less visible, they are of no less importance to ecosystem functioning -- thus biologically and legally -- they must receive equal consideration. 
The problem is that, due to a lack of research, surprisingly little is known about the distribution, habitat associations, and even the life histories of many of the smaller or uncommon manmals. Many are fossorial or nocturnal, and so are seldom encountered.

In this manual we have attempted, through extensive literature reviews and expert reviewers, to assemble the best information available on the habitat associations of northeastern mammals. We acknowledge that their uses of the several timber types and age classes vary -- species prefer some over others. Such preferences are not indicated in the tables that follow. Also, populations vary greatly -- in years of high population levels, individuals will occur in otherwise marginal or even poor habitats.

Many of these species' distributions have not been studied such that definitive statements about their relative uses of various forest types and successional stages can be made. We encourage the reader to make corrections, additions, or deletions when they have knowledge of species in their locality -- we have provided a column to check local occurrence in the summary tables.

The scientific names follow those used in Mammals of the Eastern United States by W. J. Hamilton, Jr. and J. 0. Whitaker, Jr. (1979. Corne11 University Press, I thaca, New York, 346 p.) except for the Thompson's pygmy shrew, which has been given full species status in accordance with C. A. Long's Taxonomic revision of the mammalian genus Microsorex Coues (1972. Trans. Kansas Acad. Sci. 74:181-196). 
The 65 species of mammals in this guide were selected because all or part of their range fell within the New England Planning Area of the Eastern Region, USDA Forest Service (Fig. 1).

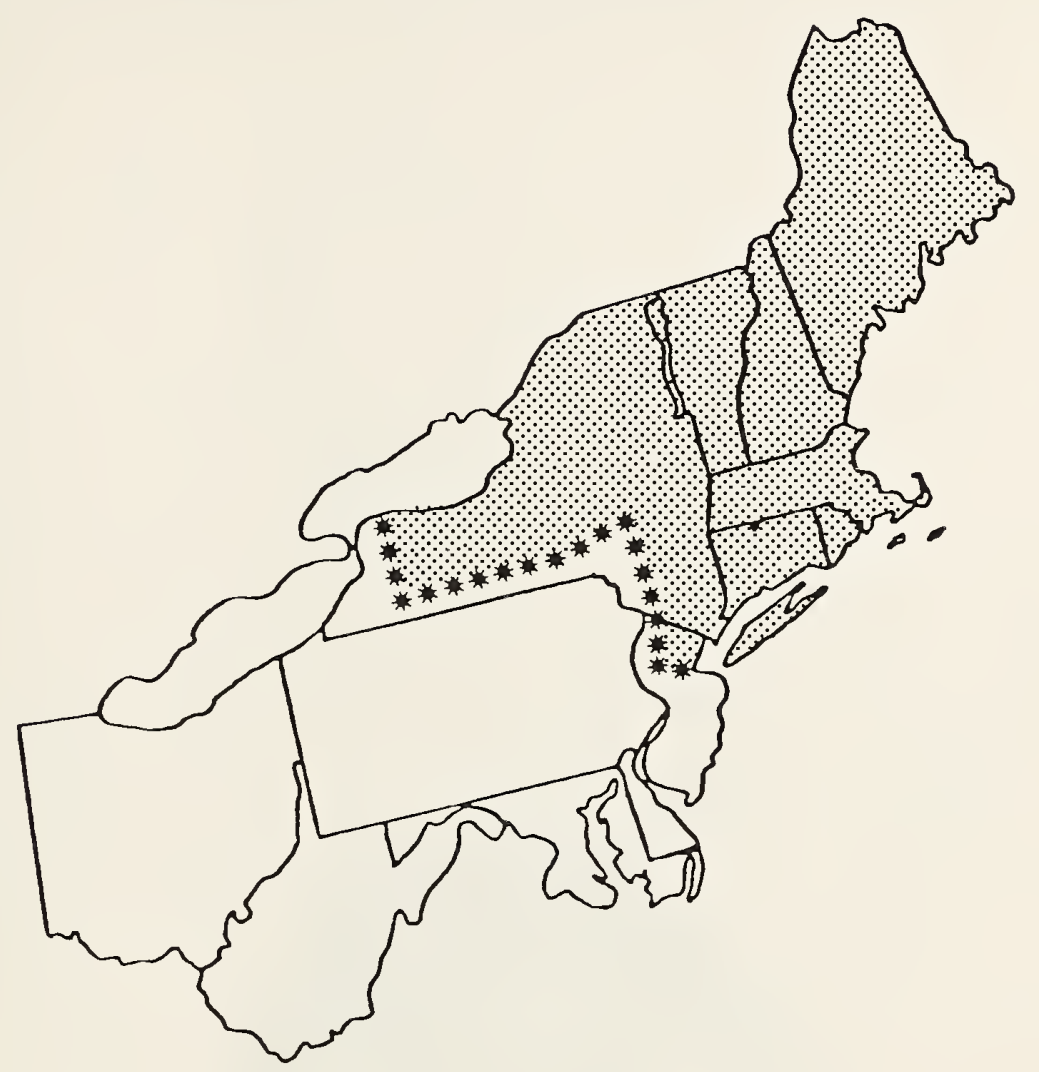

Fig. 1 - Map of the New England Planning Area, Eastern Region USDA Forest Service.

Although the guide is limited to mammals of the eight-state New England Planning Area, the natural history profiles and range maps have been expanded to cover thirteen northeastern states. This was done to make the guide useful to biologists and foresters in neighboring states where most of these forest (community) types and mammals are also found.

This management guide is the first such undertaking for the northeastern United States. We hope that the information it contains will help foresters 
and biologists to relate mammalian communities and habitats to land management practices. For relationships with other classifications of plant communities, Figure 2 presents the equivalent schemes.

The following section contains definitions of the terminology used.

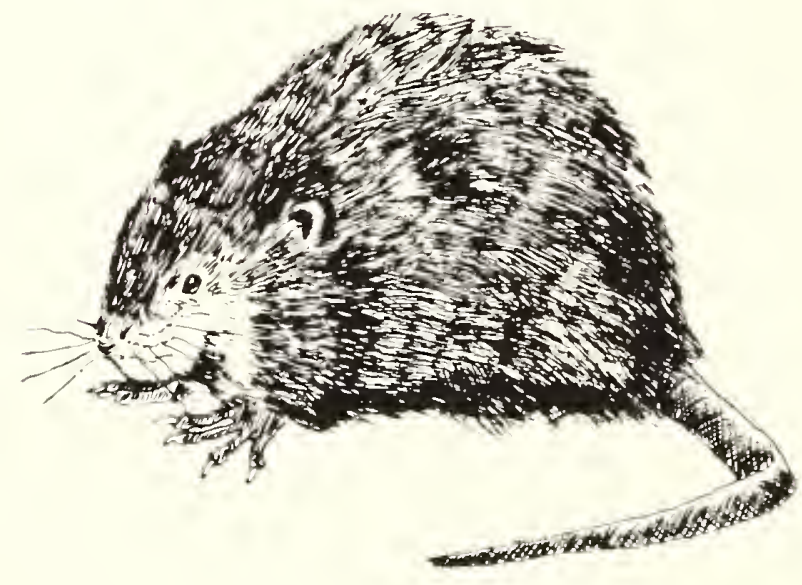




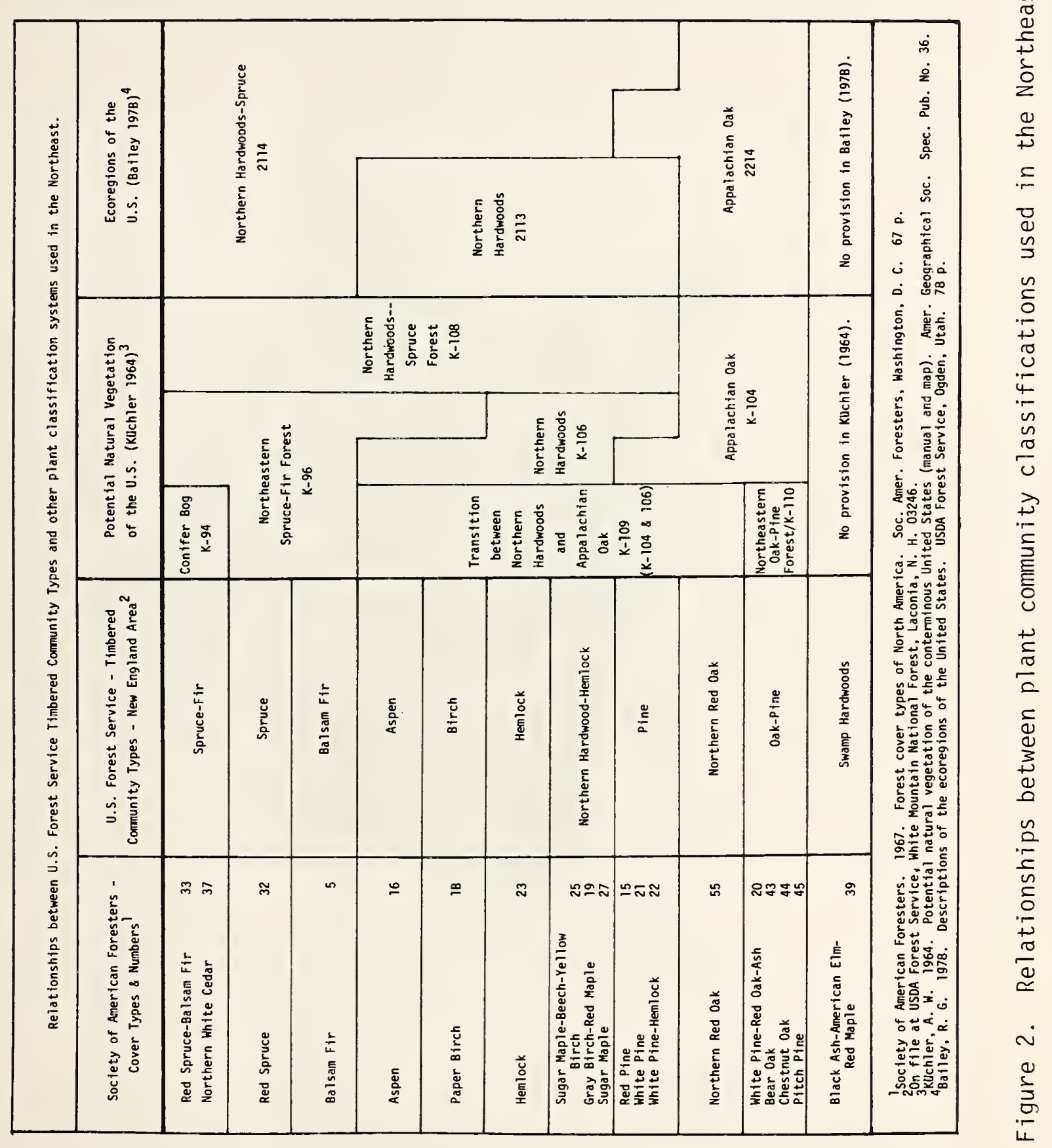




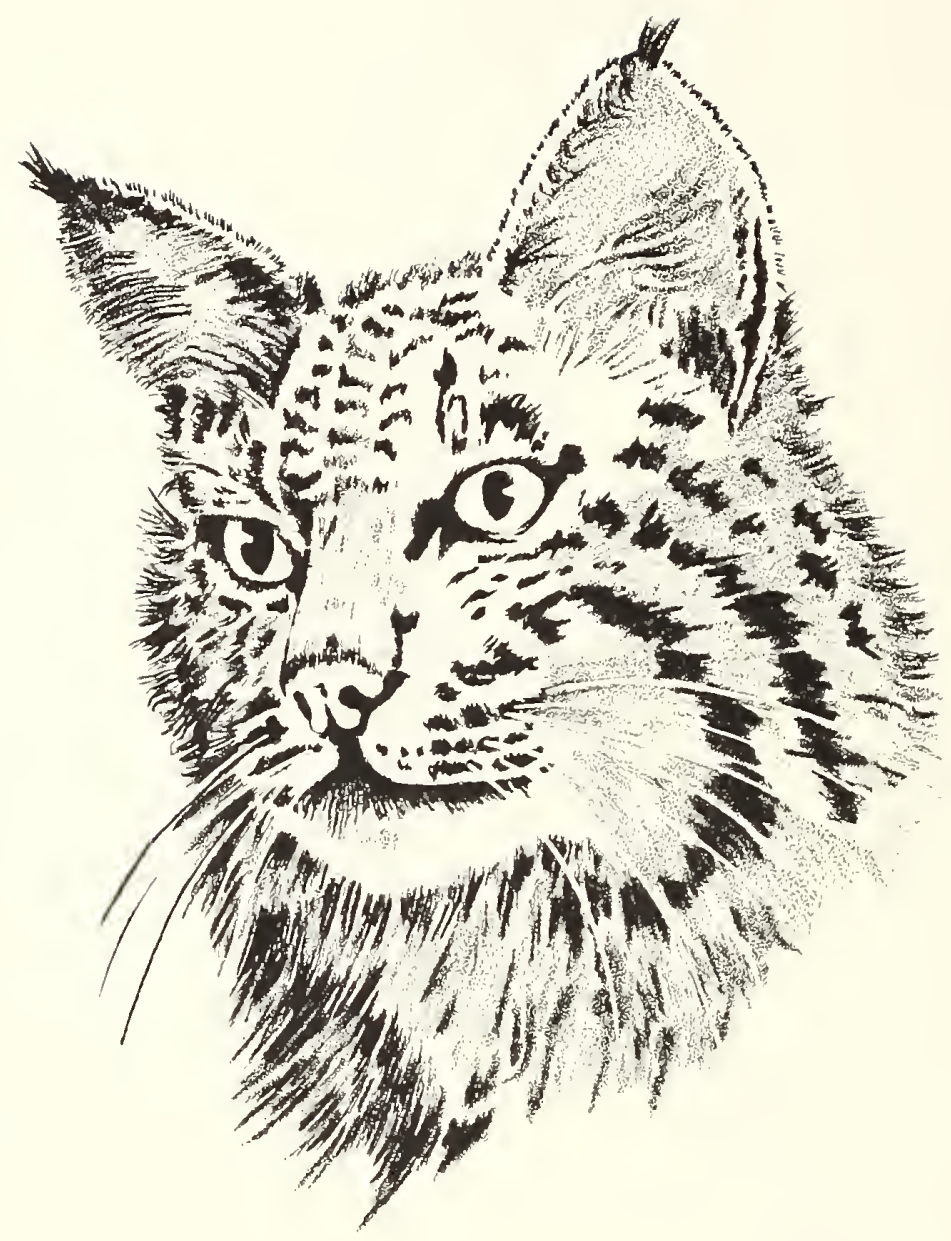




\section{DEFINITIONS}

Alpine Zone - Elevated slopes above timberline characterized by the presence of low, shrubby, slow-growing woody plants and a ground cover of boreal species of grasses, sedges and lichens.

Community - An association of many plants, animals, and micro-organisms living together interdependently. It occupies a specific area and has a sufficiently uniform condition as to be distinguishable from adjoining areas. A forest community would be a forest stand at a particular successional stage, such as a sapling birch stand.

Community Type - A distinctive group or assemblage of plants and animals. A community type may be a forest type, a wetland type, an opening type or other characteristic land surface type. A forest community type would include all successional stages from regeneration to old growth. For example, a birch community type includes a 11 birch stands in all successional stages.

Diversity - A measure of variety in ecosystems - expressed as the total number of different kinds of life in relation to their relative abundance. Kinds of life may refer either to species of plants or animals, or to groups of these.

Ecosystem - A varied, intricately interwoven assemblage of plants and animals, together with its abiotic components.

Forage - All vegetation, except mast and fruits of woody plants, that is available and acceptable to herbivorous animals.

Forb - Any herb other than grasses (Gramineae) and grasslike plants (Cyperaceae and Juncaceae).

Herb - A flowering plant with a stem that does not become woody or persistent. An herb dies annually after a season of growth or after flowering. The term includes forbs and grasses.

Home Range - The area in which an individual animal spends its normal 1ife. Individuals, pairs, or family groups of vertebrates and the higher invertebrates commonly restrict their activities to a definite home range.

Krummholz Zone - The transition zone from subalpine forest to alpine tundra characterized by dwarfed, deformed, wind-sheared trees.

Mast - Nuts and fruits of trees or shrubs that are eaten by wildlife.

Mature Stands - Areas covered by trees of smal1 sawtimber size - larger than nine inches D.B.H. if conifers and 11 inches D.B.H. if hardwoods. Competition between trees has eliminated some overtopped or diseased 
individuals. Shade tolerant species such as beech, hemlock and sugar maple are common in such stands. Very few large trees (14 inches or more D.B.H.) or snags are present in such stands, and dense shade prevents understory development, although some understory plants exist.

Nonvegetative, Rock, Sand, Mud, etc. - Land components which do not conform to the definitions for other nontimbered community types. Generally has a geologic origin, but may include man-made habitats such as gravel pits, quarries, buildings and other structures.

01d Growth - Areas covered by trees which are on the average larger than fourteen inches D.B.H. with diseased and damaged trees becoming noticeable as they approach pathological (natural) rotation. Snags for cavity nesters become abundant; mortality and windfall create small clearings that soon become pockets of regenerating growth.

Opening - Land on which grasses, herbs, and shrubs dominate the vegetation, including but not limited to "nonforest" and "unproductive forest." Openings may contain some trees.

Opening-Undifferentiated - A land area having high solar illumination at the ground level. An opening can be dominated by land features such as water or rock or by vegetation features such as grasses, forbs or shrubs.

Orchard - Areas one-half acre or larger where fruit trees - usually apple - are abundant. Groups of trees can be classified as "orchard" if they occur in clumps of five or more trees or where there are more than ten trees per acre. At this tree density, the fruits produced constitute a significant food source for many wildlife species.

Pasture - Grazing land under relatively intensive management, usually supporting introduced forage species, and receiving periodic cultural treatment such as tillage, fertilization, mowing, and irrigation.

Regenerating Stands - Areas in the process of being restocked with trees. Trees are of seedling and small sapling size - up to 5 inches in diameter at breast height (D.B.H.). Tree species present are very intolerant of shade such as aspen, cherry, paper birch, and sometimes pine. Stands in this size group are important in producing grasses, forbs, and shrubby growth in abundance for ground-nesting and feeding birds.

Relative Abundance (of mammal species): abundant - very plentiful common - readily found to be present uncommon - not readily found, but present rare - present in such low numbers that a finding is considered noteworthy. 
Savanna - Land areas dominated by grasses and sedges, with open stands of widely spaced trees. A savanna results from either soil-moisture regimes or disturbances such as fire or grazing.

Shrub - A plant that has persistent, woody stems and a relatively low growth habit, and generally produces several basal shoots instead of a single bole.

Territory - A home range or a part of a home range that is actively defended. Territoriality is the term used to describe the activity that spaces individuals or groups apart from one another.

Water

Lake greater than 10 acres - Water 3-10' or more deep, generally applies to lakes and ponds. Submergent and surface vegetation may be present in shallower portions.

Stream, River - Flowing water, usually has a well-defined channel to which water area is confined.

Wetland

Undifferentiated - Poorly drained land where water stands for several months of the year. These lands have characteristic vegetation including: sedges, rushes, cattails, reed canary grass, buttonbush, reeds, arrowarum, willow.

Sedge Meadow - Wetland dominated by vegetation such as: sedges, cattails, reed canary grass. May be covered with up to 6" of surface water during late fall, winter, and early spring. During the summer, the soil is exposed but saturated. Shallow depressions and drainage ditches will continue to have surface water.

Shallow Marsh - Wetland dominated by emergent vegetation, with an average water depth less than 6" during the growing season. Surface water can be present throughout the year or absent during late summer and abnormally dry periods. Surface and submergent vegetation normally present in open areas.

Deep Marsh - Wetland with average water depth between 6" and $3^{\prime}$ during the growing season. Emergent plants or wetland shrubs usually dominant. Surface and submergent vegetation is present in open water.

Open Water less than 10 acres - Water 3-10' deep, which can be associated with any wetland, but most commonly with deep and shallow marshes. Submergent and surface vegetation are dominant.

Shrub Swamp - Wetland dominated by shrubs; soil is seasonally or permanently flooded by water, 1 foot or less deep. Emergents such as sedges, or sensitive fern may occur between shrubs. Open areas may have more dense emergent cover. 
Bog - Wetlands with peat accumulations. Low oxygen levels and cool temperatures reduce decomposition and allow organic material to accumulate. Acidic conditions prevalent. A floating peat mat covering part of the water surface is common.

Submergent Vegetation - Plants which grow below the water surface. Flowering parts of some species may be above the water surface.

Emergent Vegetation - Rooted vegetation that is primarily above the water surface. Herbs growing out of water, but on saturated soils are included in this definition.

Surface Vegetation - Floating plants with most of plant occurring on the water surface.

Wildlife Habitat - The place where animals live. Also refers to the plant communities upon which they are dependent for their livelihood.

Young Stands - Areas in the process of becoming dominated by tree species rather than by shrubs, forbs, or grasses. Tree stems are of sapling size, averaging 5 to 9 inches D.B.H. in softwoods and 5 to 11 inches D.B.H. in hardwoods. More tolerant species such as red maple, and yellow birch, are commonly found in young stands. 
The forest community types in the New England Area are presented below with age groups as they exist under even age management. Only in Northern Hardwoods-Hemlock is an all-age group shown. These community types are the basic forest classification units upon which this guide is based.

AGE GROUPS OF TIMBERED COMMUNITY TYPES

NEW ENGLAND AREA

\begin{tabular}{|c|c|c|c|}
\hline Community Type & Age Classes $1 /$ & Age (yrs.) & $\begin{array}{l}\text { Timber Species } \\
\text { or Groups Included }\end{array}$ \\
\hline Aspen & $\begin{array}{l}R \\
Y \\
M \\
0\end{array}$ & $\begin{array}{c}0-9 \\
10-39 \\
40-59 \\
60+\end{array}$ & $\begin{array}{l}\text { Quaking aspen } \\
\text { Big-tooth aspen } \\
\text { Aspen-fir }\end{array}$ \\
\hline Birch & $\begin{array}{l}R \\
Y \\
M \\
0\end{array}$ & $\begin{array}{c}0-9 \\
10-49 \\
50-79 \\
80+\end{array}$ & Paper birch \\
\hline $\begin{array}{l}\text { Northern Hardwood- } \\
\text { Hemlock }\end{array}$ & $\begin{array}{l}R \\
Y \\
M \\
0 \\
A\end{array}$ & $\begin{array}{c}0-9 \\
10-59 \\
60-119 \\
120+ \\
\text { a11-aged }\end{array}$ & $\begin{array}{l}\text { Sugar maple-beech- } \\
\text { yellow birch } \\
\text { Red maple (dry) } \\
\text { Sugar maple } \\
\text { Beech }\end{array}$ \\
\hline Swamp Hardwoods & $\begin{array}{l}R \\
Y \\
M \\
0\end{array}$ & $\begin{array}{c}0-9 \\
10-59 \\
60-119 \\
120+\end{array}$ & $\begin{array}{l}\text { Black ash-American } \\
\text { elm-red maple } \\
\text { Red maple (wet) }\end{array}$ \\
\hline Northern Red Oak & $\begin{array}{l}R \\
Y \\
M \\
0\end{array}$ & $\begin{array}{c}0-9 \\
10-59 \\
60-99 \\
100+\end{array}$ & Northern red oak \\
\hline Oak-Pine & $\begin{array}{l}\mathrm{R} \\
\mathrm{Y} \\
\mathrm{M} \\
0\end{array}$ & $\begin{array}{c}0-9 \\
10-59 \\
60-99 \\
100+\end{array}$ & $\begin{array}{l}\text { Other oak-pine } \\
\text { White pine-red oak- } \\
\text { ash }\end{array}$ \\
\hline
\end{tabular}


AGE GROUPS OF TIMBERED COMMUNITY TYPES - NEW ENGLAND AREA (cont'd)

\begin{tabular}{|c|c|c|c|}
\hline Community Type & Age Classes $1 /$ & Age (yrs.) & $\begin{array}{l}\text { Timber Species } \\
\text { or Groups Included }\end{array}$ \\
\hline Balsam Fir & $\begin{array}{l}R \\
Y \\
M \\
0\end{array}$ & $\begin{array}{c}0-9 \\
10-39 \\
40-69 \\
70+\end{array}$ & $\begin{array}{l}\text { Balsam-aspen- } \\
\text { paper birch }\end{array}$ \\
\hline Pine & $\begin{array}{l}R \\
Y \\
M \\
0\end{array}$ & $\begin{array}{c}0-9 \\
10-69 \\
70-119 \\
120+\end{array}$ & $\begin{array}{l}\text { Red pine } \\
\text { White pine } \\
\text { White pine-hemlock }\end{array}$ \\
\hline Spruce-fir & $\begin{array}{l}R \\
Y \\
M \\
0\end{array}$ & $\begin{array}{c}0-9 \\
10-39 \\
40-89 \\
90+\end{array}$ & $\begin{array}{l}\text { Red spruce-balsam fir } \\
\text { Northern white cedar } \\
\text { Mixed swamp conifer } \\
\text { Cedar-aspen-paper birch }\end{array}$ \\
\hline Spruce & $\begin{array}{l}R \\
Y \\
M \\
0\end{array}$ & $\begin{array}{c}0-9 \\
10-39 \\
40-99 \\
100+\end{array}$ & Red spruce \\
\hline Hemlock & $\begin{array}{l}R \\
Y \\
M \\
0\end{array}$ & $\begin{array}{l}0-9 \\
10-69 \\
70-119 \\
120+\end{array}$ & Hemlock \\
\hline $\begin{array}{l}\text { 1/ R - Regener } \\
Y \text { - Young, } \\
M \text { - Mature } \\
0 \text { - 01d-gro } \\
\text { A - Al1-age }\end{array}$ & athological & on age & \\
\hline
\end{tabular}




\section{MAMMALS OF THE NEW ENGLAND AREA.}

Marsupialia

Didelphidae

Virginia opossum (Didelphis virginiana)

Insectivora

Soricidae

Masked shrew (Sorex cinereus)

Water shrew (Sorex palustris)

Smoky shrew (Sorex fumeus)

Long-tailed shrew (Sorex dispar)

Thompson's pygmy shrew (Microsorex thompsoni)

Short-tailed shrew (BLarina brevicauda)

Least shrew (Cryptotis parva)

Talpidae

Hairy-tailed mole (Parascalops breweri)

Eastern mole (Scalopus aquaticus)

Star-nosed mole (Condylura cristata)

\section{Chiroptera}

Vespertilionidae

Little brown myotis (Myotis Zucifugus)

Keen's myotis (Myotis keenii)

Indiana myotis (Myotis sodalis)

Smal1-footed myotis (Myotis leibii)

Silver-haired bat (Lasionycteris noctivagans)

Eastern pipistrelle (Pipistrellus subflavus)

Big brown bat (Eptesicus fuscus)

Red bat (Lasiums borealis)

Hoary bat (Lasiurus cinereus)

Lagomorpha

Leporidae

Eastern cottontail (SyZvizagus floridanus)

New England cottontail (Sylvizagus transitionalis)

Snowshoe hare (Lepus comericanus)

Black-tailed jackrabbit (Lepus califomicus)

European hare (Lepus europaeus) 


\section{Rodentia}

Sciuromorpha

Sciuridae

Eastern chipmunk (Tamias striatus)

Woodchuck (Marmota monax)

Gray squirrel (Sciums carolinensis)

Red squirrel (Tamiasciums hudsonicus)

Southern flying squirrel (Glaucomys volans)

Northern flying squirrel (Glaucomys sabrinus)

Castoridae

Beaver (Castor canadensis)

Myomorpha

Cricetidae

Deer mouse (Peromyscus maniculatus)

White-footed mouse (Peromyscus leucopus)

Eastern woodrat (Neotoma floridana)

Gapper's red-backed mouse (Clethrionomys gapperi)

Meadow vole (Microtus pennsyzvanicus)

Rock vole (Microtus chrotorrhinus)

Pine vole (Microtus pinetomu)

Muskrat (Ondatra zibethicus)

Southern bog lemming (Synaptomys cooperi)

Northern bog lemming (Synaptomys borealis)

Muridae

Black rat (Rattus rattus)

Norway rat (Rattus norvegicus)

House mouse (Mus musculus)

Zapodidae

Meadow jumping mouse (Zapus hudsonius)

Woodland jumping mouse (Napaeozapus insignis)

Hystricomorpha

Erethizontidae

Porcupine (Erethizon dorsatum)

\section{Carnivora}

Canidae

Coyote (Canis Latrans)

Red fox (Vulpes vulpes)

Gray fox (Urocyon cinereoargenteus) 


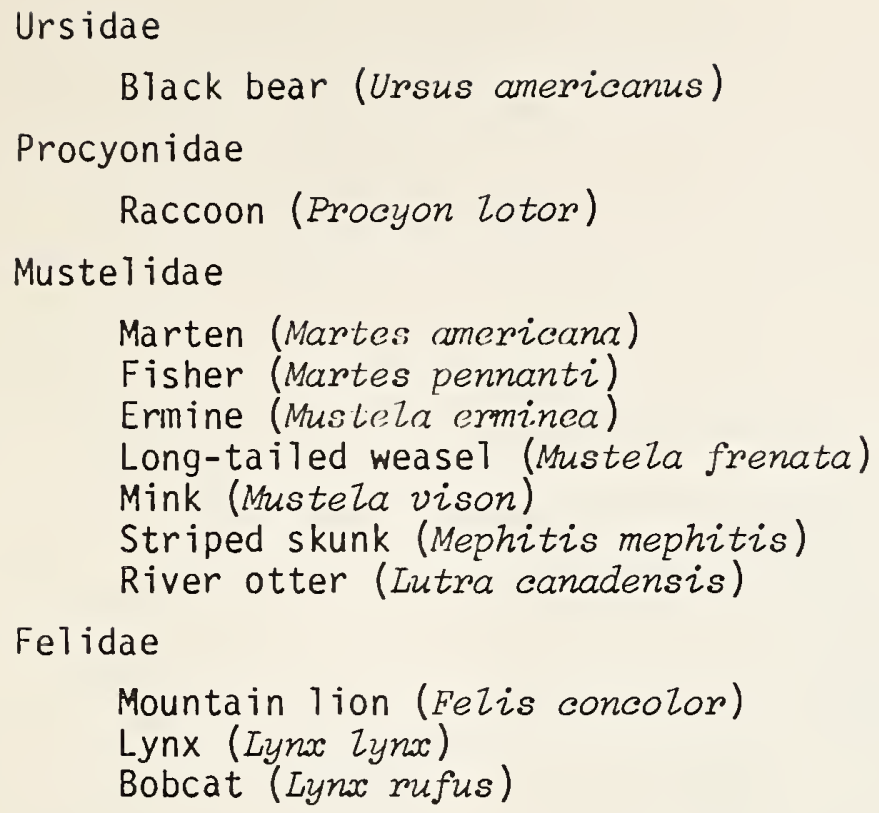

Artiodactyla

Cervidae

White-tailed deer (Odocoileus virginiarus)

Moose (Alces alces) 


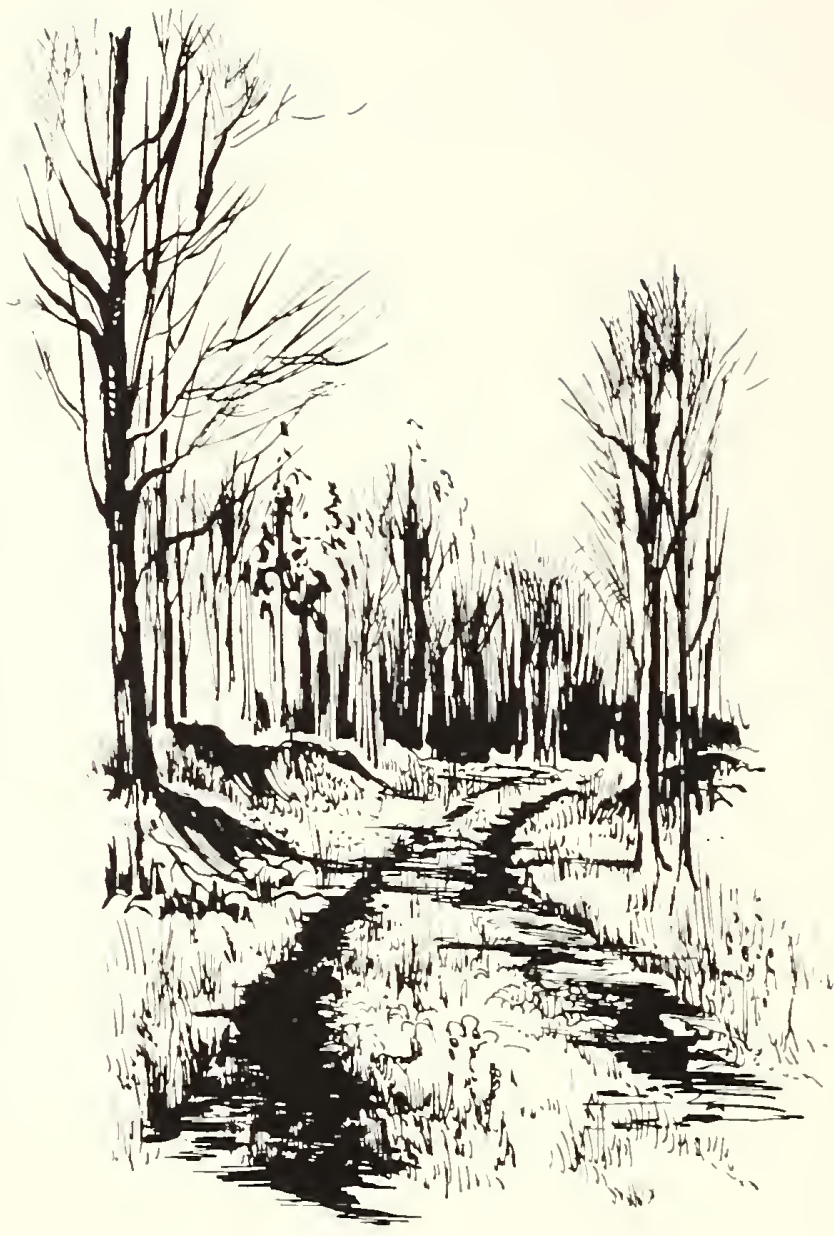


The following tables present habitat associations for mammals whose ranges occur in the New England Planning Area. Associations are presented for timbered communities and age classes, and for nontimbered communities, including wetland types. The tables summarize use of the habitats for feeding and reproduction, and indicate primary habitats. For convenience, use of habitats for resting and hibernation are shown on line $\mathrm{R}$ (reproduction) for the relatively few species to which they apply.

Numerical versatility indices are given at the right margins of the tables to facilitate species/habitat comparisons. When read vertically, for example, one may quickly separate species with specialized (stenoecious) habitat associations from those with more versatile (euryecious) associations. These indices are intended for approximate comparisons only and are defined as follows:

Community type versatility - Number of community types used for reproducing or feeding divided by the total number of types (11) and expressed as a percent. Age class versatility - Average of the percents of age classes used within community types.

Overa11 versatility (timbered community types) - Number of age/ type classes used for reproducing or feeding divided by the total number of age/type classes (4.5) and expressed as a percent. Versatility - Nontimbered--number of community types used divided by total number of types (31) and expressed as a percent.

Note that the tabular material or use of communities should be used in conjunction with the habitat descriptions provided in the natural history profiles. 


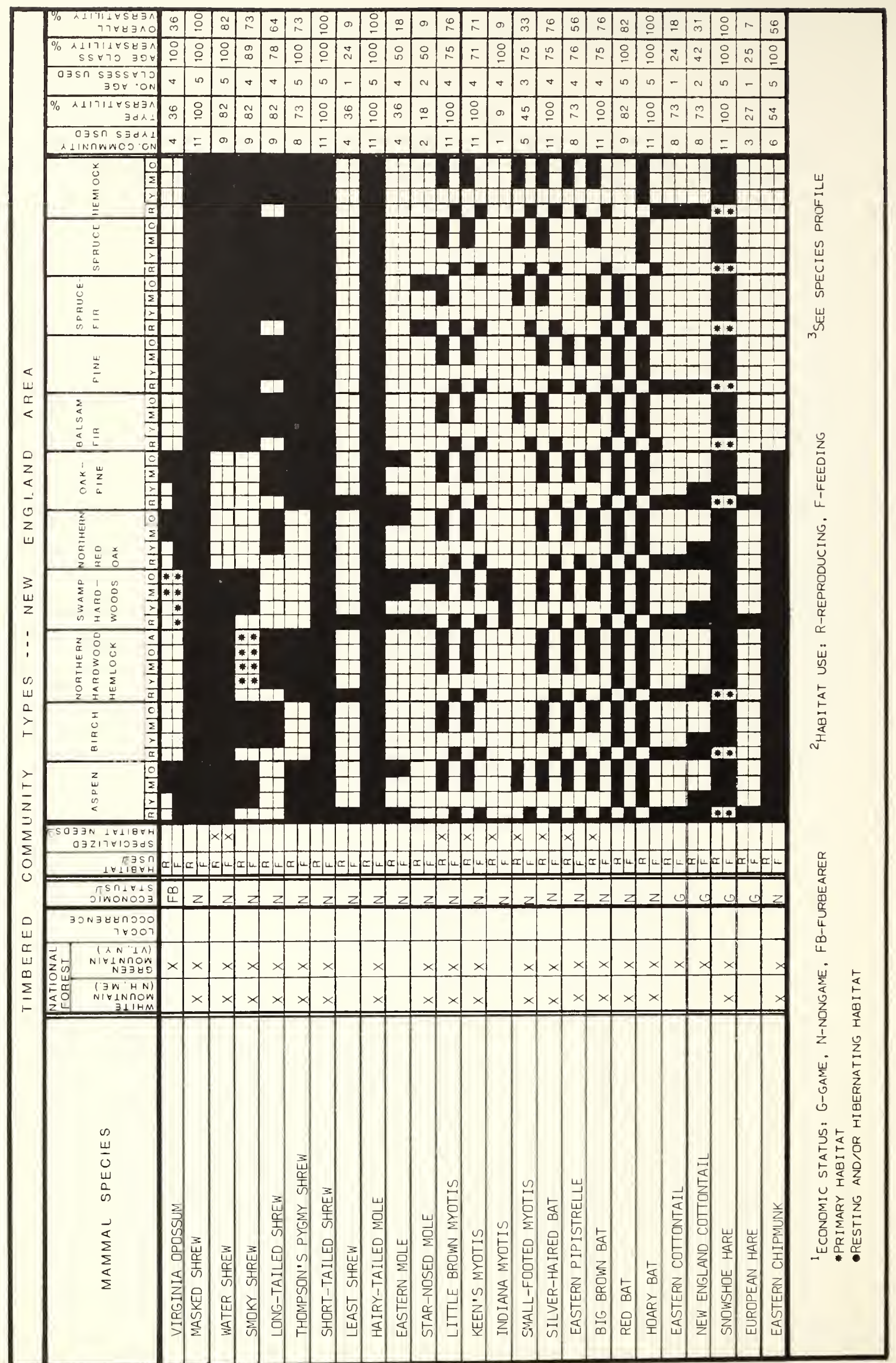




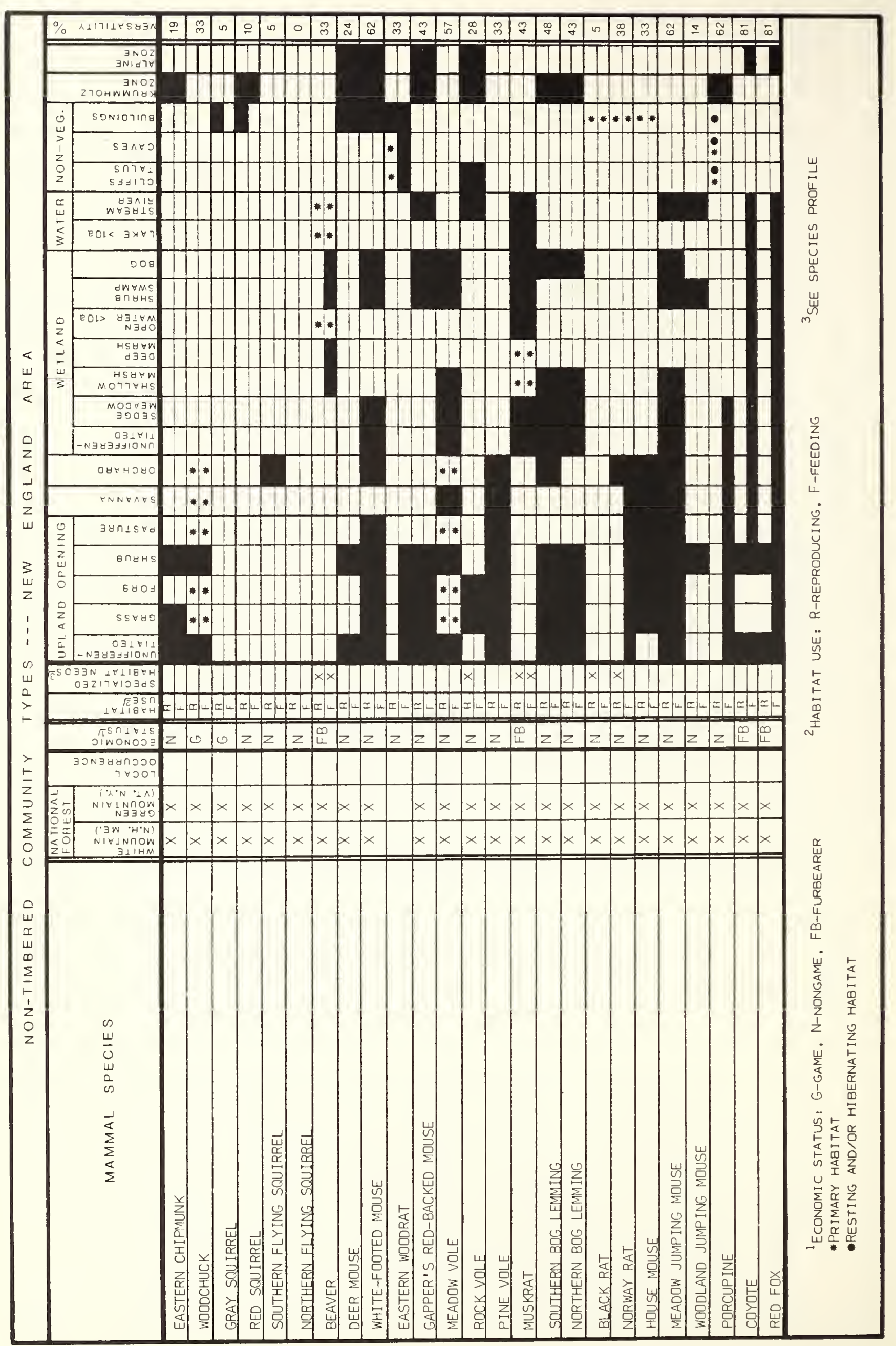




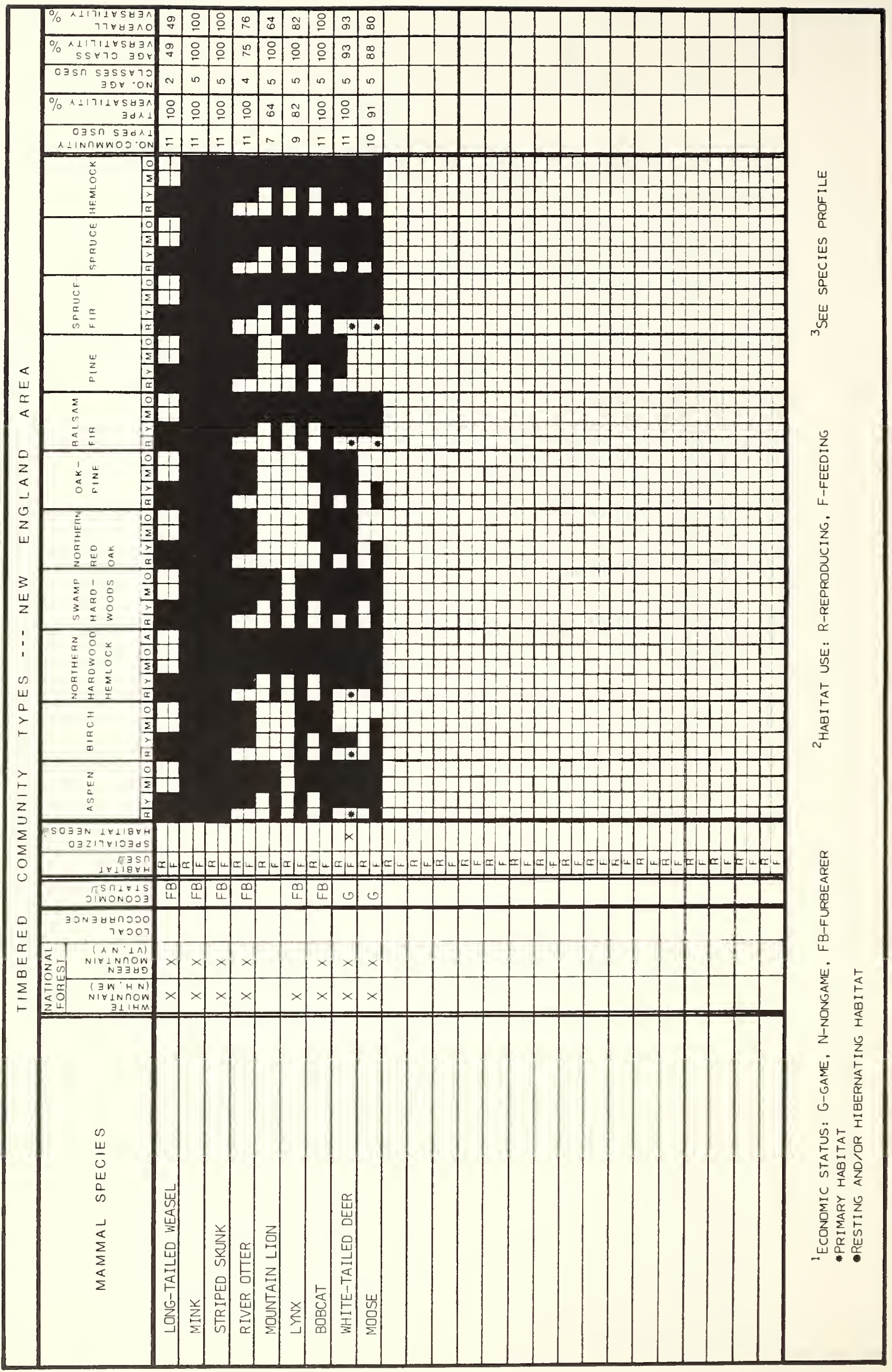




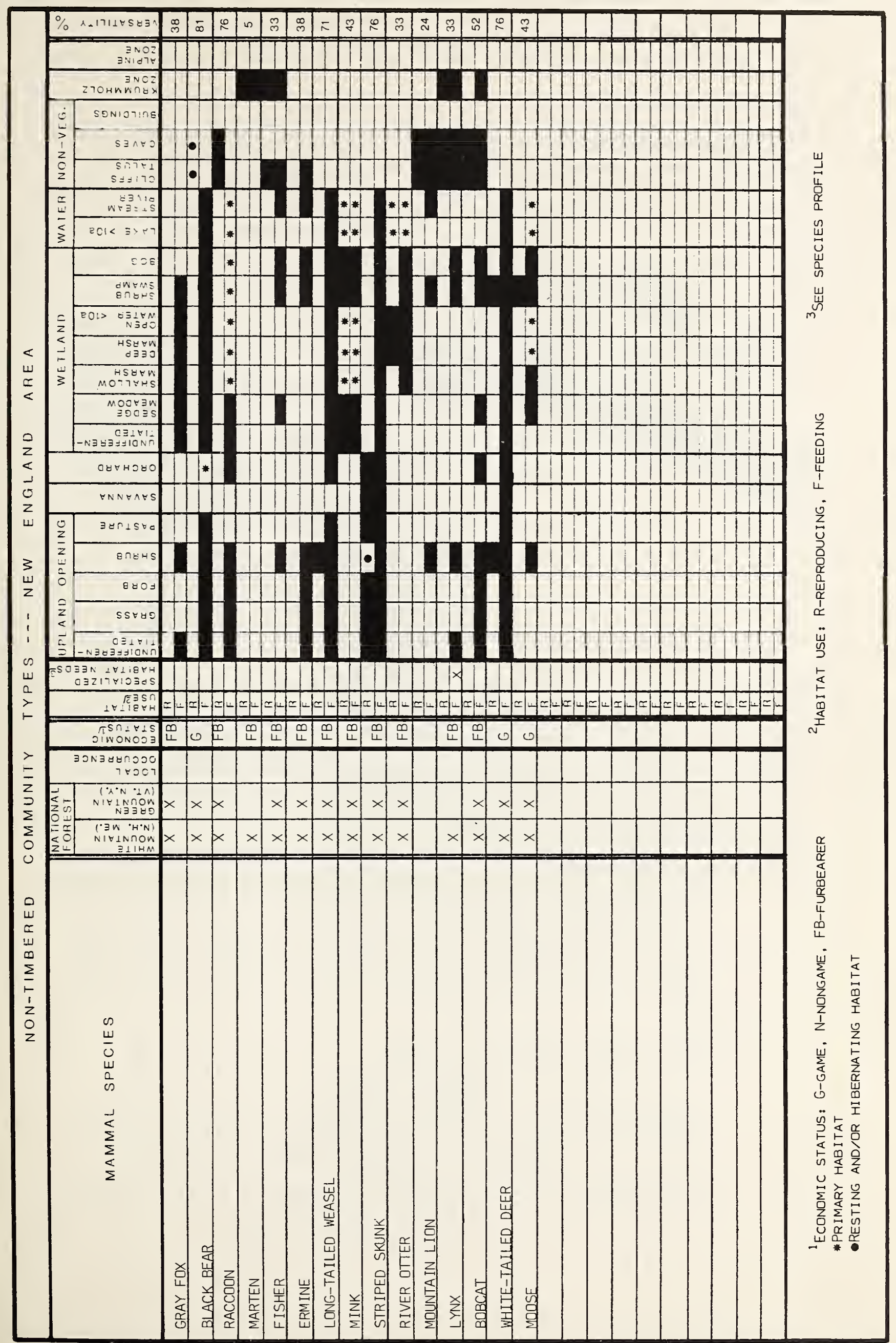




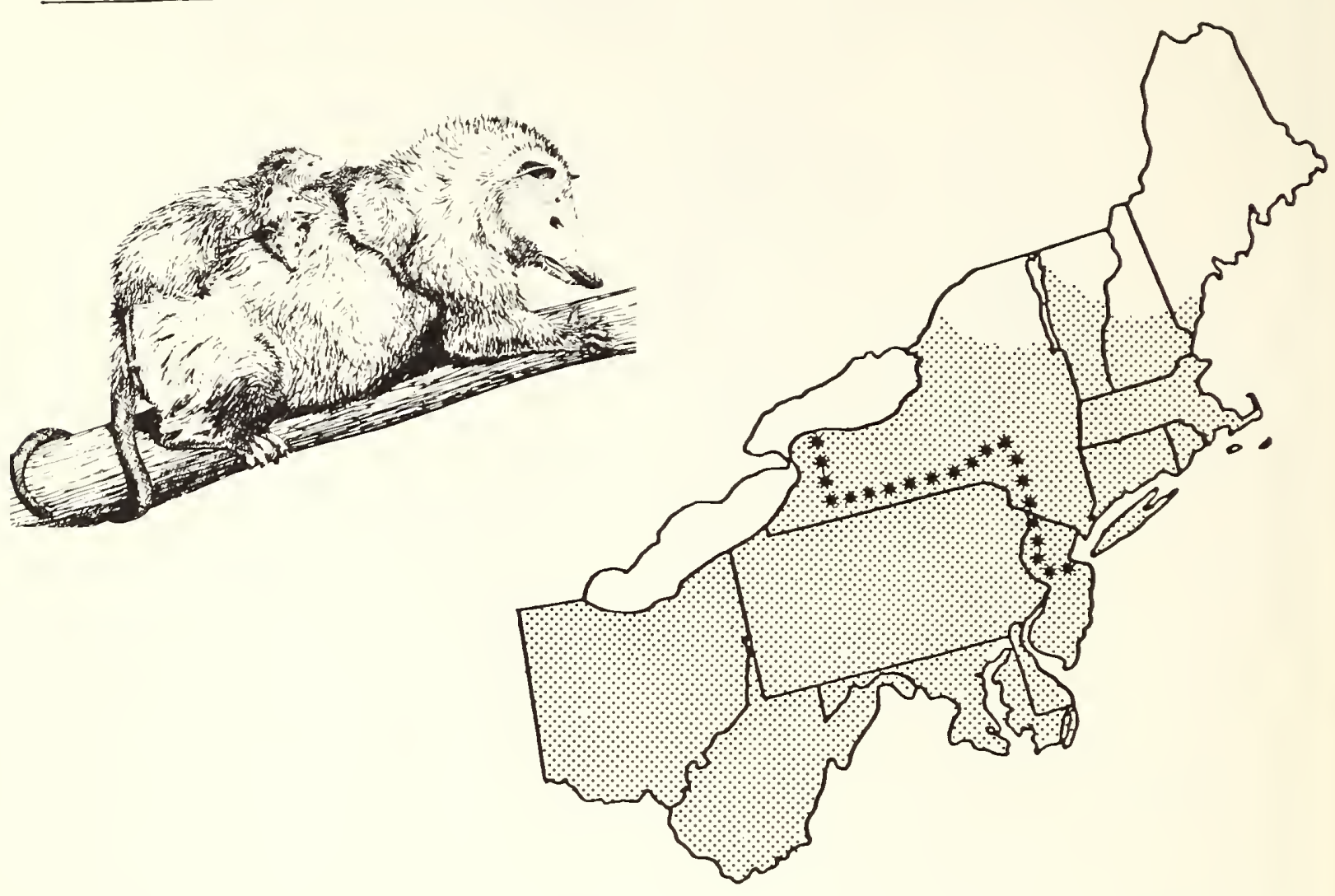

Range: Throughout the eastern U.S. except northern New England. Also occurs along the West Coast and in parts of Central America.

Relative abundance in the Northeast: Common to uncommon

Habitat in the Northeast: Dry to wet wooded areas; commonly found in wet woods near rivers and swamps, less often in wooded uplands or cultivated fields. Common near human habitation where they are attracted to garbage.

Special habitat requirements: Den (usually in abandoned burrow, tree cavity, hollow log or brush pile); water (Llewellyn and Dale 1964).

Reproduction

Age at sexual maturity: 1 year

Breeding periods: Late January to early July, New York

(Hami1ton 1958)

Gestation period: 13 days (Lay 1942)

Young born: February to July in extremely undeveloped stage and remain in females' pouch for 60 days

Litter size: 5 to 13 , average 8

No. 1itters/year: 1 1itter/year in north, 2 or 3 1itters/year in south (Walker 1975:24) 
Home range: Average minimum range was 11.5 acres ( 4.7 ha). Range 0.33 to 58 acres ( 0.1 to $23.5 \mathrm{ha}$ ) for 29 opossums in East Texas (Lay 1942). 15 to 40 acres ( 6 to 16 ha) (Burt and Grossenheider 1976:1). Average minimum length of 25 elongate ranges in several habitats in Maryland was 0.6 mile $(1 \mathrm{~km})$ (Llewellyn and Dale 1964).

Food habits: Insects, worms, fruits, nuts, carrion and garbage; almost any vegetable or animal food (Lay 1942).

Economic status: Furbearer

Comments: In winter, opossums become less active but do not hibernate (McManus 1971). Individuals in the north are often lacking ears and tails due to frostbite. Avoids predators by feining death and voiding noxious odors (Francq 1969).

Key natural history references: Lay 1942, Wiseman and Hendrickson 1950. Hartman 1953, Hamilton 1958, Llewellyn and Dale 1964, McManus 1974. 


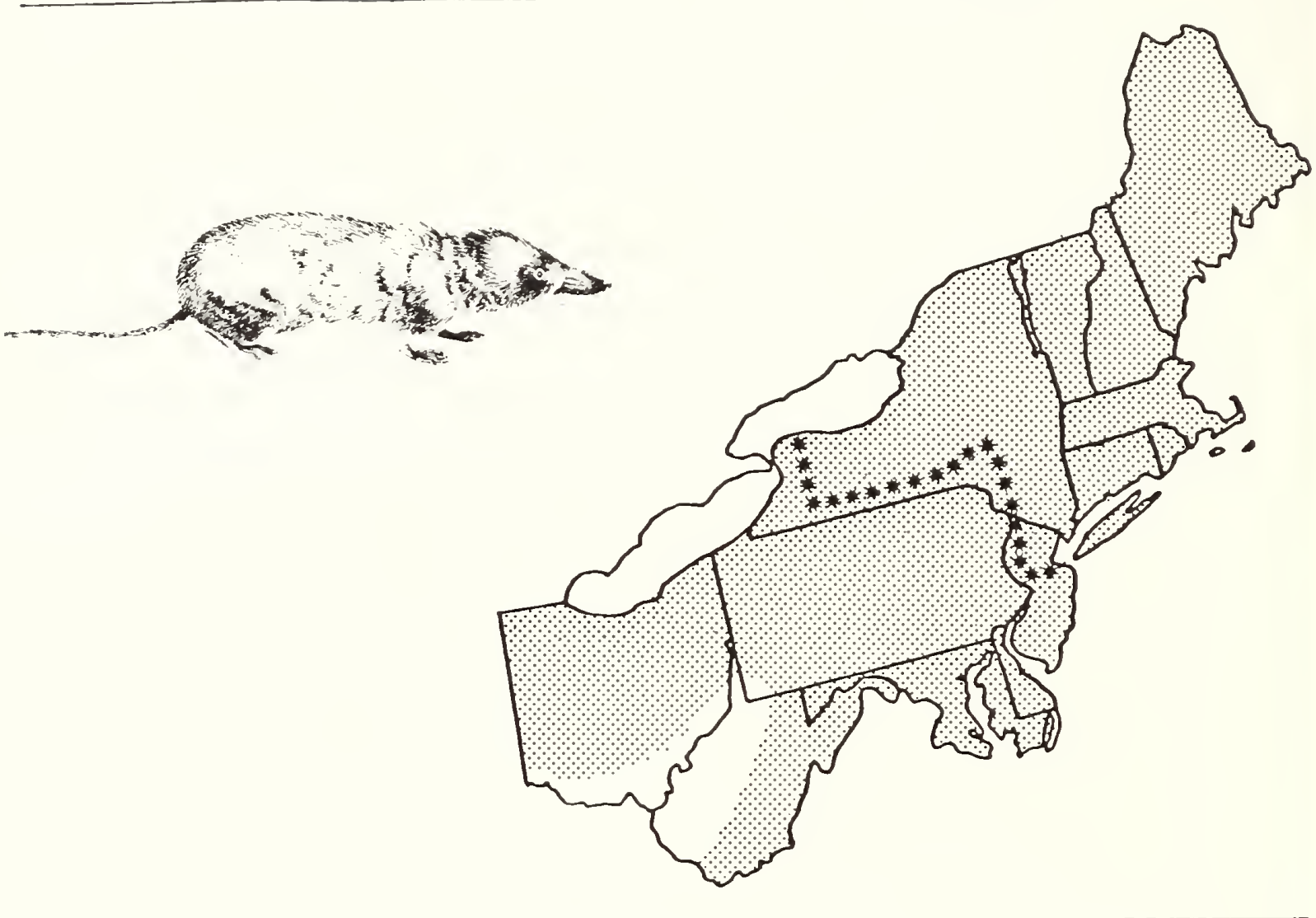

Range: Throughout Canada and Alaska south to North Carolina, New Mexico (mountains), and central Washington.

Relative abundance in the Northeast: Common to uncommon

Habitat in the Northeast: Damp deciduous and coniferous woodlands with grasses, rocks, logs or stumps for cover; bogs and other moist areas. Less often in open country with abundant moisture or in dry woods. Kirkland (1977b) found them in clearcuts in West Virginia.

Special habitat requirements: High humidity (moist sites) (Banfield 1974:9), ground cover (especially leaves, rotten logs, herbaceous vegetation).

Reproduction

Age at sexual maturity: 20 to 26 weeks (Short 1961)

Breeding period: Late April to late September or October (Banfield 1974:9)

Gestation period: Probably 18 days (Peterson 1966:36, Godin $1977: 24)$

Young born: Late April to late September or October. Litter size: 2 to 10, average 4.4 (Banfield 1974:9)

No. litters/year: Up to 3 litters may be produced in a single season 
Home range: About 0.10 acre (0.04 ha) (Banfield 1974:9).

Sample density: Densities of up to 9 individuals/acre (22/ha) have been reported in favorable habitats (Banfield 1974:9).

Food habits: Mainly insectivorous and carnivorous. Also consumes worms, spiders, snails, slugs and small amounts of vegetable matter. Feeds among litter on forest floor.

Economic status: Non-game

Comments: Young are independent when about 1 month old (Godin 1977:24). Nests in grass, or under logs, rocks or brush. Active throughout winter.

Key natural history references: Banfield 1974, Walker 1975, Wrigley et a1 1979. 


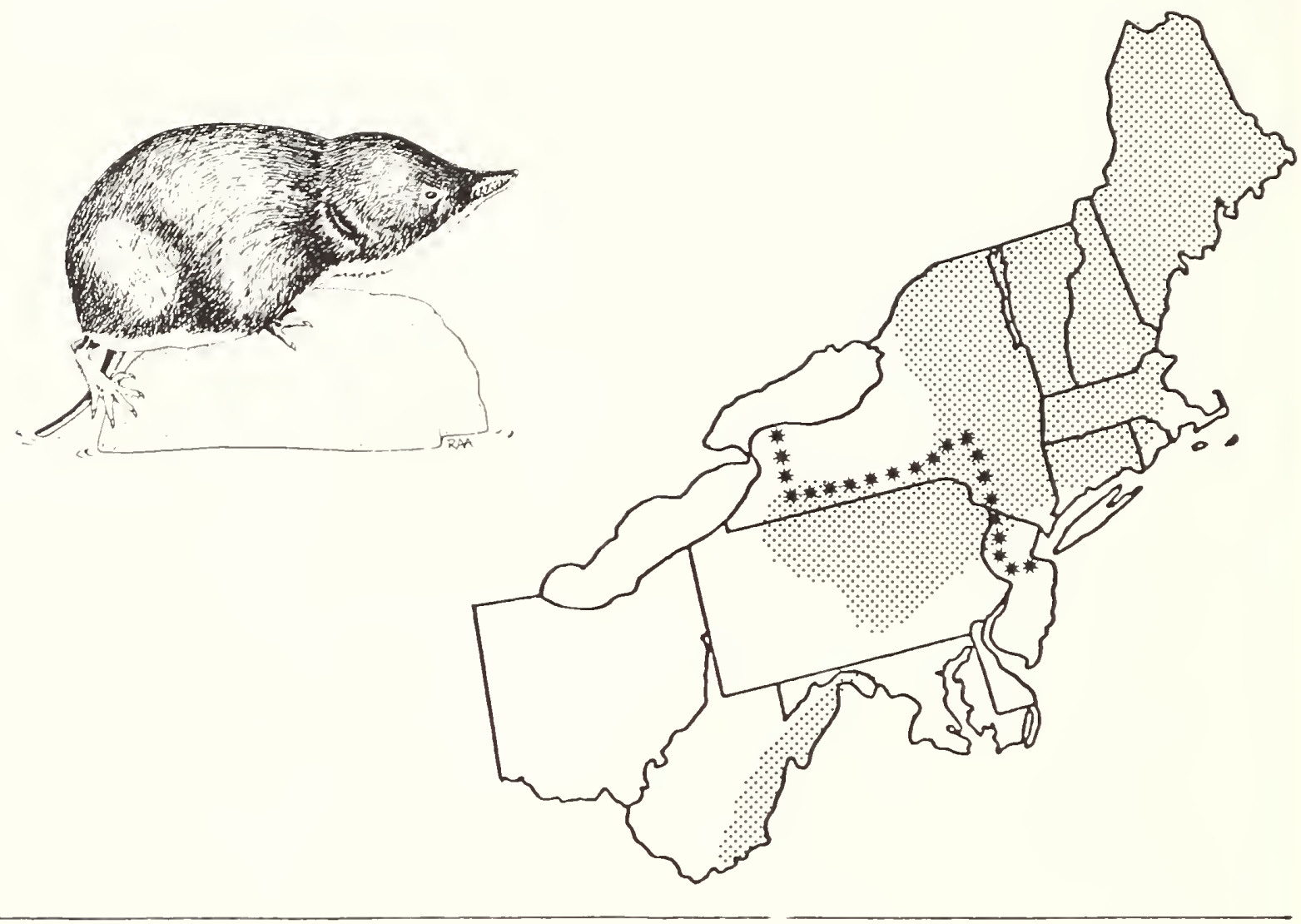

Range: Nova Scotia and southern Quebec west to British Columbia, south through New England, much of New York, Pennsylvania, and the southern Appalachians. Also occurs in the mountains of the West.

Relative abundance in the Northeast: Uncommon

Habitat in the Northeast: Wet areas especially grass-sedge marsh or shrub zones along ponds and streams in coniferous forest (Wrigley et al 1979). Also at wooded shores with favorable cover in the form of crevices beneath boulders, tree roots or overhanging banks.

Special habitat requirements: Herbaceous cover, body of cold water (bog, stream, lake, etc.).

Reproduction

Age at sexual maturity: Possibly 9 months

Breeding period: Possibly February to August

Peak: Possibly March to July

Gestation period: Probably about 21 days (Conaway 1952)

Young born: Probably March to August

Litter size: 4 to 8 , average 6

No. 1itters/year: Possibly 2 to 3 litters are produced each year by mature females (Banfield 1974:14) 
Home range: 0.5 and 0.8 acres ( 0.2 and $0.3 \mathrm{ha})$ for two individuals live-trapped in Manitoba (Buckner and Ray 1968).

Food habits: Insectivorous - mainly eats larvae of aquatic insects.

Also takes snails, flatworms, and small fish (Banfield 1974:14).

Economic status: Non-game

Comments: Little is known about the habits of this species.

Key natural history references: Conaway 1952, Banfield 1974, Wrigley et al 1979 . 


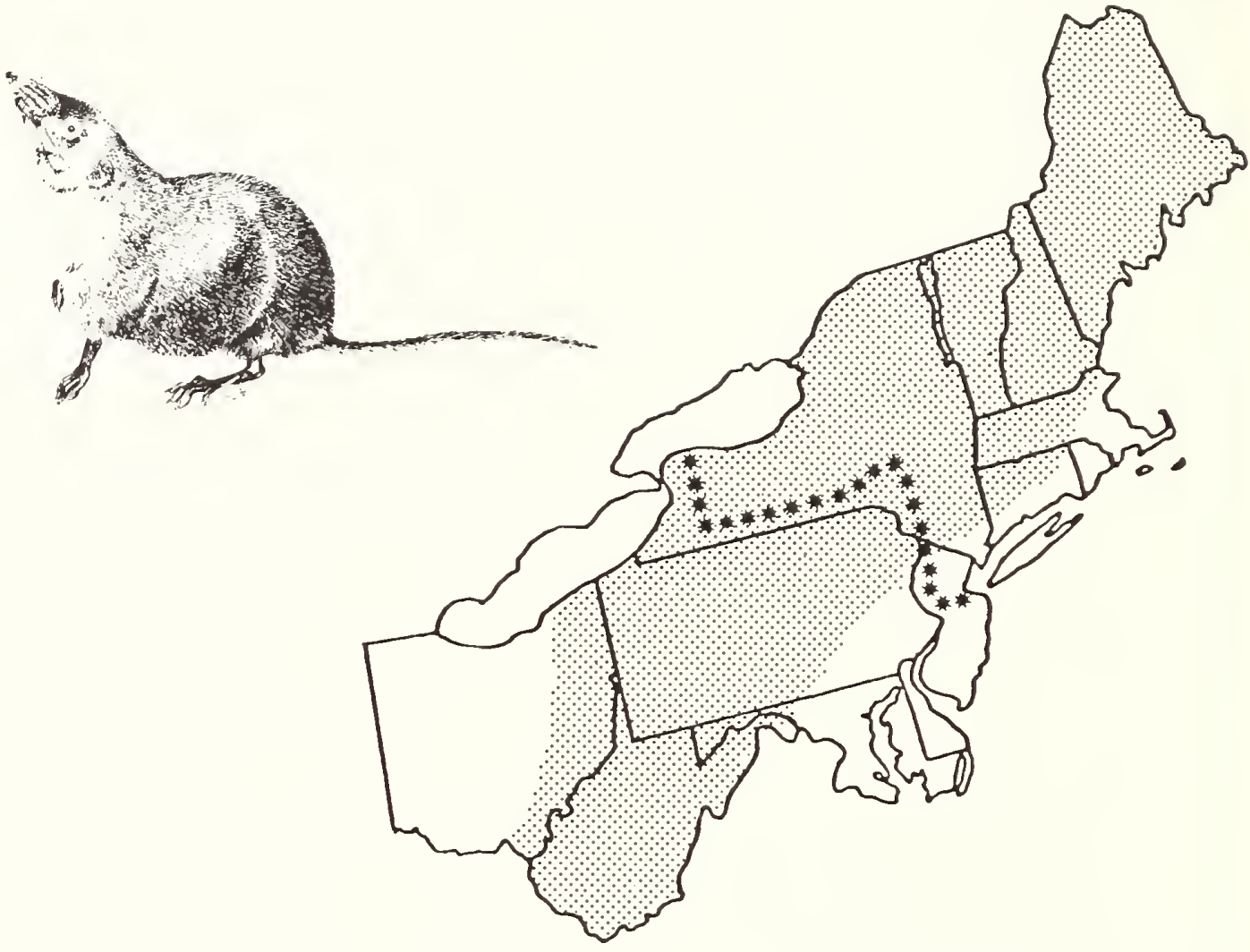

Range: Maritime Provinces, southern Quebec and Ontario west to Lake Superior. Southern Maine south through parts of southern New England, Ohio, Kentucky and Georgia.

Relative abundance in the Northeast: Locally common to uncommon

Habitat in the Northeast: Damp, boulder-strewn, upland woods (often beech or maple, birch and hemlock) with thick leafmold. Typically near streams with moss-covered banks (Burt and Grossenheider 1976:5, Godin 1977:27). Also uses early clearcuts in coniferous woodlands (Kirkland 1977b).

Special habitat requirements: Loose damp leaf litter--does not burrow, uses runways of other small mammals (Banfield 1974:16) in shady wooded areas (Peterson 1966:38).

Reproduction

Age at sexual maturity: Spring following first winter Breeding period: Late March to early August (New York) (God in $1977: 27$ )

Gestation period: About 20 days (Hamilton 1940)

Young born: Mid-April through August (New York) (Hamilton 1940) Litter size: 2 to 8 , average 5 to 6 (Hamilton 1940) No. litters/year: Up to 3 (Hamilton 1940) 
Sample density: Ranged from 5 to 50 individuals per acre ( 12 to $123 /$ ha) in late summer (Hamilton 1940).

Food habits: Mainly insectivorous (80\%) but also eats earthworms, spiders, snails, salamanders, small mammals and birds (Hamilton 1940:480).

Economic status: Non-game.

Comments: Usually nests beneath stump, rotten log or in tunnels dug by larger mammals (Banfield 1974:16, Godin 1977:27). Active throughout winter (Banfield 1974:16).

Key natural history references: Hamilton 1940, Banfield 1974, Godin 1977. 


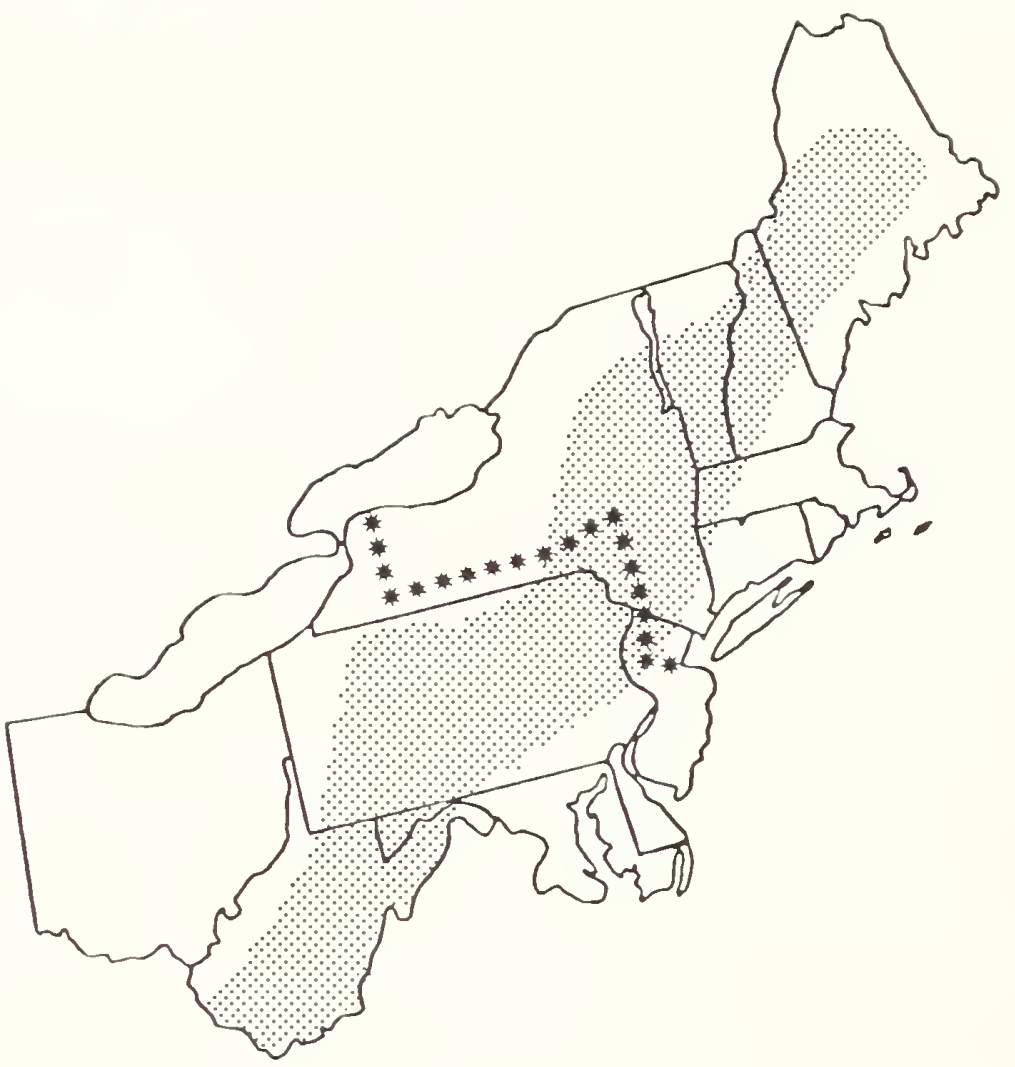

Range: Central and western Maine south in the Appalachians to North Carolina.

Relative abundance in the Northeast: Undetermined - possibly rare

Habitat in the Northeast: Cold, damp coniferous forests, typically near moss-covered rocks and logs which provide shady protective crevices or wooded talus slopes (Richmond and Grimm 1950, Conner 1960). Also found in deciduous and mixed forests (Burt and Grossenheider 1976:6). Five individuals were found in a one year old red spruce clearcut in West Virginia (Kirkland et a). 1976). Others have been taken in road construction rubble (Conaway and Pfitzer 1952).

Special habitat requirements: Rocky, wooded sites.

\section{Reproduction}

Age at sexual maturity: Less than 1 year

Breeding period: Possibly late April to August (Kirkland and Van Deusen 1979)

Gestation period: Unknown

Young born: Probably May to August

Litter size: 5 reported (total of 4 records for litter size) 
Home range: Unknown

Sample density: 7 individuals were trapped on 1 acre $(0.4 /$ ha $)$ of talus in Pennsylvania (Richmond and Grimm 1950).

Food habits: Mainly insectivorous. Also eats centipedes and spiders (Richmond and Grimm 1950, Connor 1960).

Economic status: Non-game

Comments: Little is known about this shrew. Occasionally it is found in moderate numbers in favorable habitat and is known to be partly subterranean.

Key natural history references: Richmond and Grimm 1950, Conner 1960, Godin 1977, Kirkland and Van Deusen 1979. 


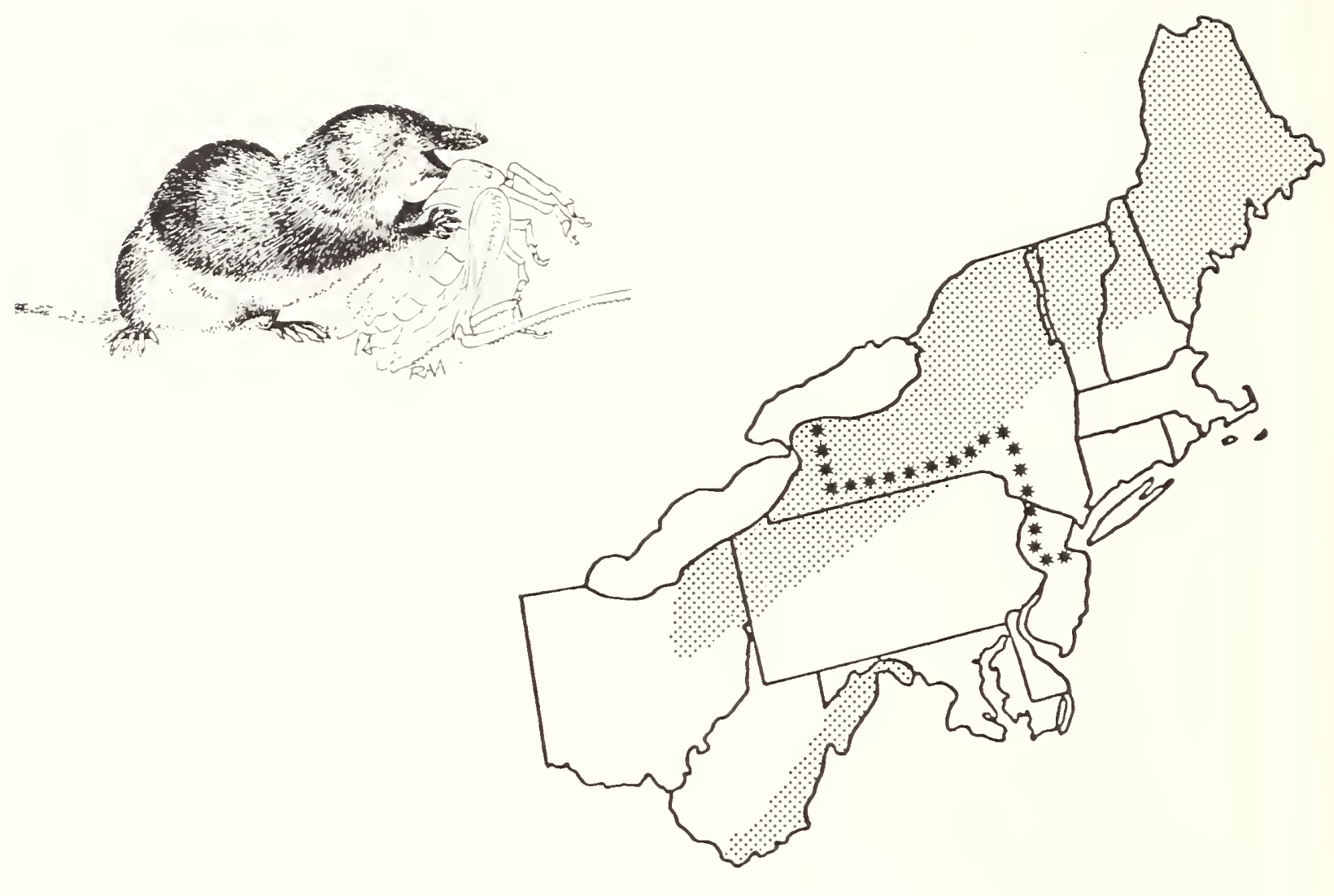

Range: Gaspe Peninsula west to southern Wisconsin, south in the Appalachians to northern Georgia.

Relative abundance in the Northeast: Rare

Habitat in the Northeast: Wet or mixed (wet-dry) habitat or less often in dry areas close to water. Found in damp litter especially near rotten stumps and logs in wooded areas. Prefers grassy openings in coniferous forests (Godin $1977: 20)$, but tolerates a variety of habitat conditions (Wrigley et al 1979).

Special habitat requirements: Moist leafmold near water.

Reproduction

Age at sexual maturity: Unknown

Breeding period: Unknown

Gestation period: Unknown

Young born: Unknown

Litter size: Unknown

No. Titters/year: May bear only 1

Home range: Unknown 
Food habits: Observed eating insects and flesh of small animals in captivity.

Economic status: Non-game

Comments: Life history is little-known.

Key natural history references: Prince 1941, Spencer and Pettus 1966, Long 1972 and 1974, Godin 1977, Wrigley et al 1979. 


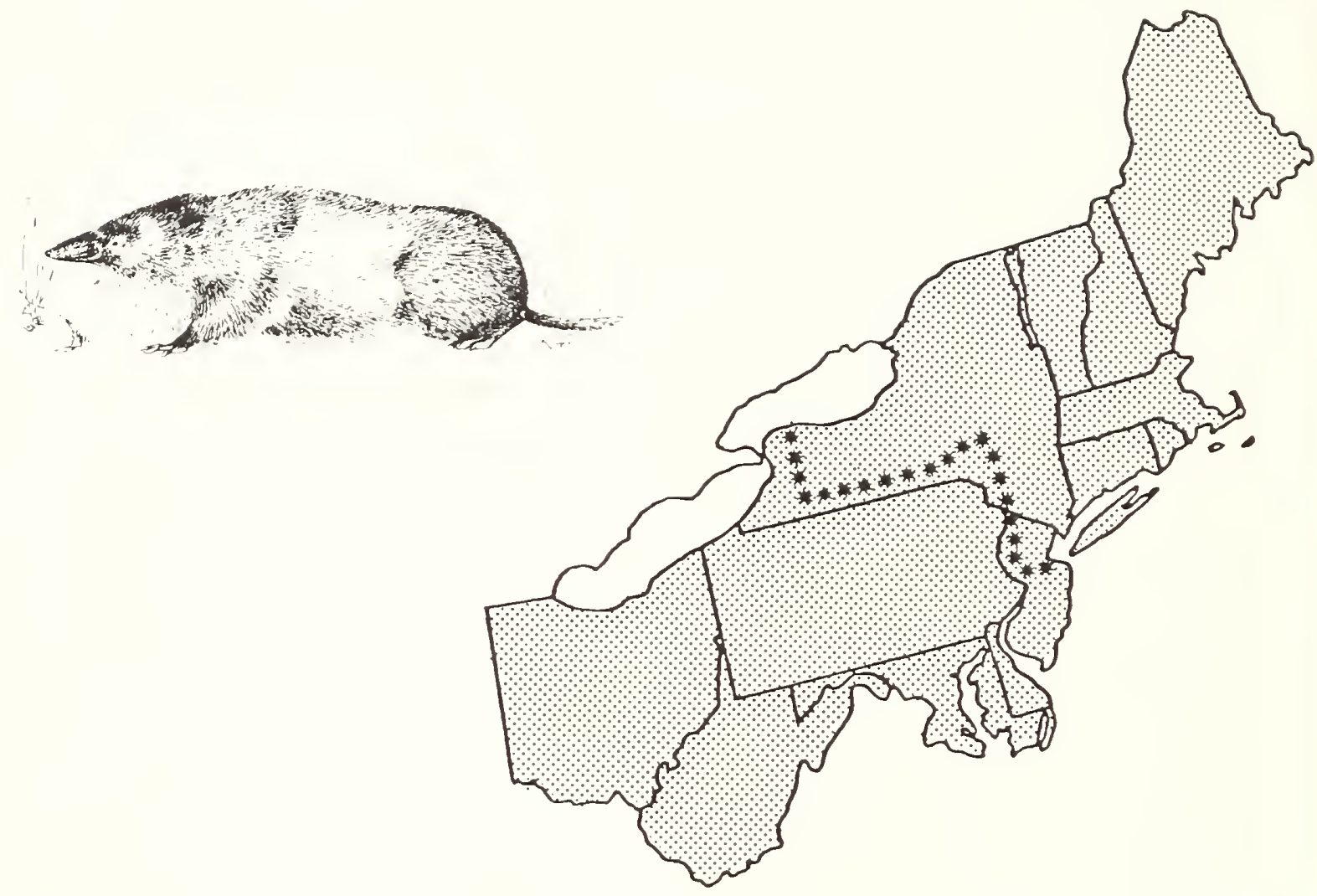

Range: Nova Scotia west to Saskatchewan, south to East Texas and southern Florida.

Relative abundance in the Northeast: Common

Habitat in the Northeast: Both timbered and non-timbered habitats: deciduous, mixed and less often coniferous forests with moist loose humus; especially common along banks of streams and in meadows with tall rank grasses or sedges, brush piles and stone wal1s. Avoids dry, warm sites (Pruitt 1959, Getz 1961a). Favored grass-sedge marsh and willow-alder shrub zone in Manitoba (Wrigley et a 1 1979).

Special habitat requirements: Low vegetation, loose leaf litter, high humidity.

Reproduction

Age at sexual maturity: Early females may mature in 6 weeks, but probably do not breed until year after their birth.

Breeding period: March to September Gestation period: 21 to 22 days Young born: Apri1 to September Litter size: 3 to 10, average 4.5 (Banfield 1974:23) No. Titters/year: 2 to 3 
Home range: 1.0 to 1.25 acres ( 0.40 to 0.51 ha) (Banfield $1974: 22$ ), 0.5 to 1.0 acre (0.2 to 0.4 ha) (Burt and Grossheider 1976:16).

Sample density: Densities of up to 48 individuals/acre (119/ha) have been reported in good habitats (Banfield 1974:22).

Food habits: Mainly insects, plants, worms, sowbugs, snails, small vertebrates, centipedes and millipedes, spiders (Banfield 1974:23).

Economic status: Non-game

Comments: Active day and night throughout the year. More fossorial than other shrews; digs own tunnels and uses burrows of other vertebrate species, especially voles.

Key natural history references: Hamilton 1931a, B1air 1940a and 1941, Burt 1940, Banfield 1974, Wrigley et al 1979. 


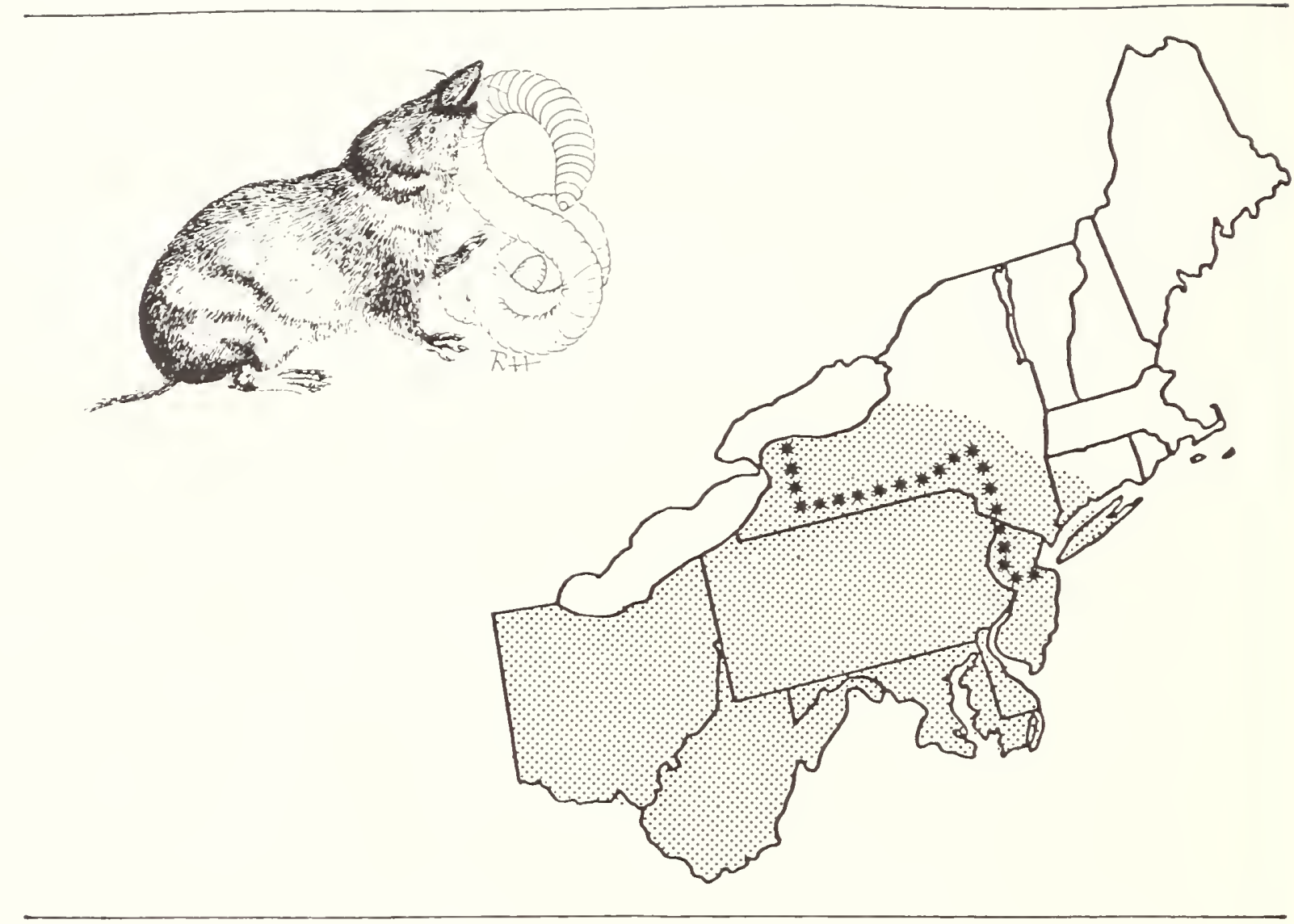

Range: Southwestern Connecticut west through central New York to South Dakota, south through East Texas and Florida.

Relative abundance in the Northeast: Undetermined - may be fairly common. Seldom caught in traps but remains often found in ow 1 pellets
(Banfield $9974: 25$ ).

Habitat in the Northeast: Open grassy areas with or without scattered brush, salt marshes, woodland edges (Banfield 1974:25, Godin $1977: 34$ ).

Special habitat requirements: Loose soils for tunnels (often uses runways of larger mice and shrews).

Reproduction

Age at sexual maturity: About 40 days (Godin 1977:35)

Breeding period: Early March to early November (at northern edge of range) (Hamilton 1944)

Gestation period: About 15 days (Godin 1977:35)

Young born: Late March to late November

Litter size: 3 to 6, average 4 or 5 (Godin 1977:35)

No. litters/year: Probably 2 to 3 
Home range: Unknown

Food habits: Insects, mollusks, amphibians, lizards, worms, mammals, and vegetable matter (Hamilton 1944).

Economic status: Non-game

Comments: Rarely nests in burrows. More often uses hollows under stones, logs or stumps. Highly social - 31 individuals were found in one winter nest (Burt and Grossenheider 1976:15).

Key natural history references: Hamilton 1944, Conaway 1952, Mock 1970. 


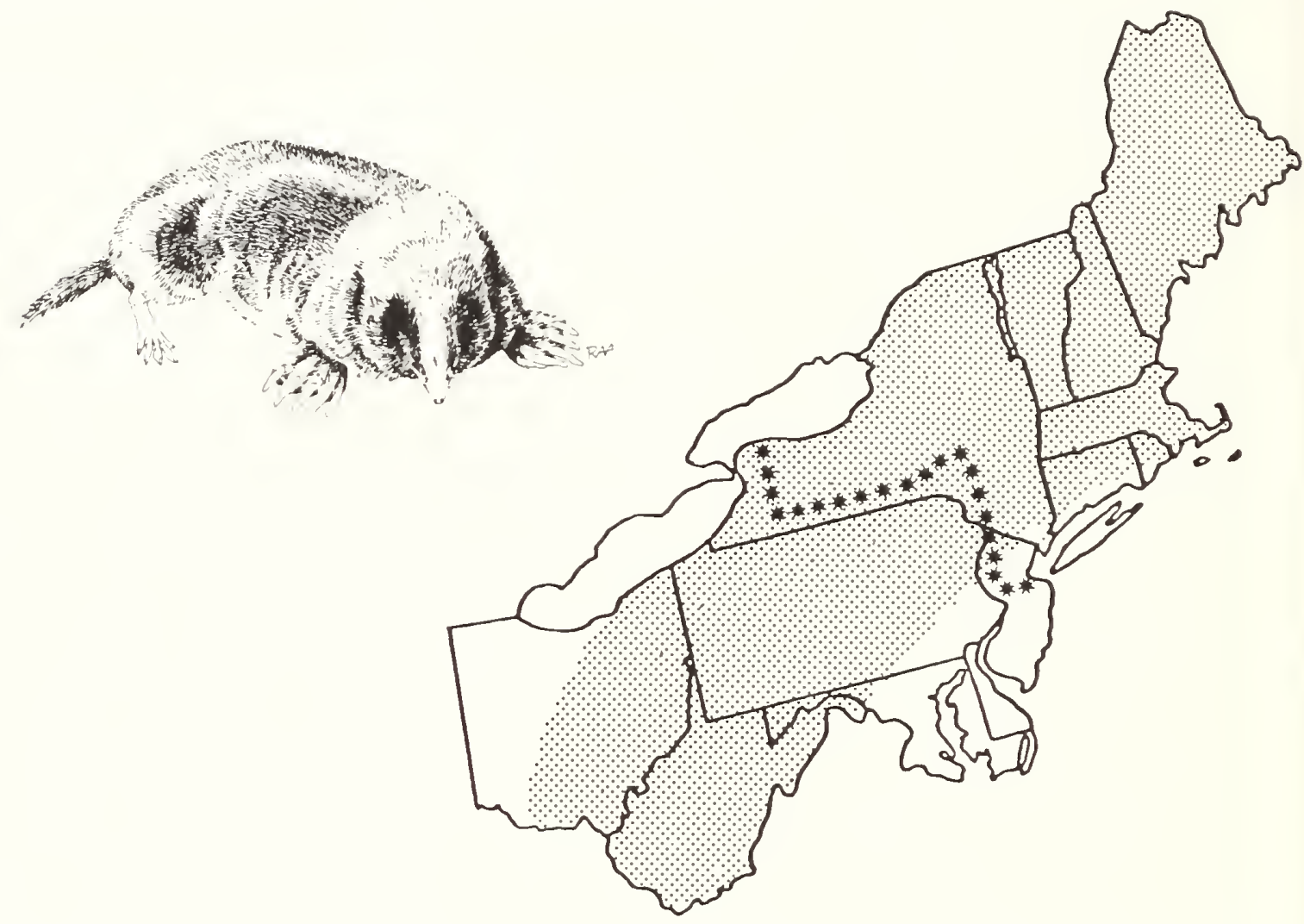

Range: New Brunswick and southeastern Quebec west to southeastern Ontario south through eastern Ohio to western North Carolina (Appalachian Mountains).

Relative abundance in the Northeast: Localiy common

Habitat in the Northeast: Open woods and meadows with light, sandy loam.

Prefers areas with vegetative cover and sufficient moisture.

Avoids heavy wet soils.

Special habitat requirements: Loose moist well-drained soil.

Reproduction

Age at sexual maturity: 10 months (Eadie 1939)

Breeding period: March and April (New Hampshire, Eadie 1939)

Gestation period: About 30 days

Young born: April and May

Litter size: 4 or 5 , average 4

No. 1itters/year: 1 (possibly 2)

Home range: About 0.2 acre (0.1 ha) (Eadie 1939). 
Sample density: An average density of 1.2 moles/acre ( $3 /$ ha $)$ on 27 acres (11 ha) and a maximum density of 11 individuals/acre (27/ha) has been reported in various habitats in New Hampshire (Eadie 1939). 10 to 12 moles/acre (25 to 30/ha) have been reported in maplebeech-hemlock woods in New York (Hamilton 1939a).

Food habits: Earthworms, insects (adults, larvae, pupae), millipedes, centipedes, snails, slugs, sowbugs (Godin 1977:37); forages on forest floor at night.

Economic status: Non-game

Comments: Constructs two tunnel systems - one shallow (just below surface), the other deep (10 to 18 inches, 25 to $46 \mathrm{~cm}$ ).

Permanent deep tunnels are sites of breeding and winter nests (Eadie 1939) and may be used for several years.

Key natural history references: Eadie 1939, Godin 1977, Hallett 1978. 


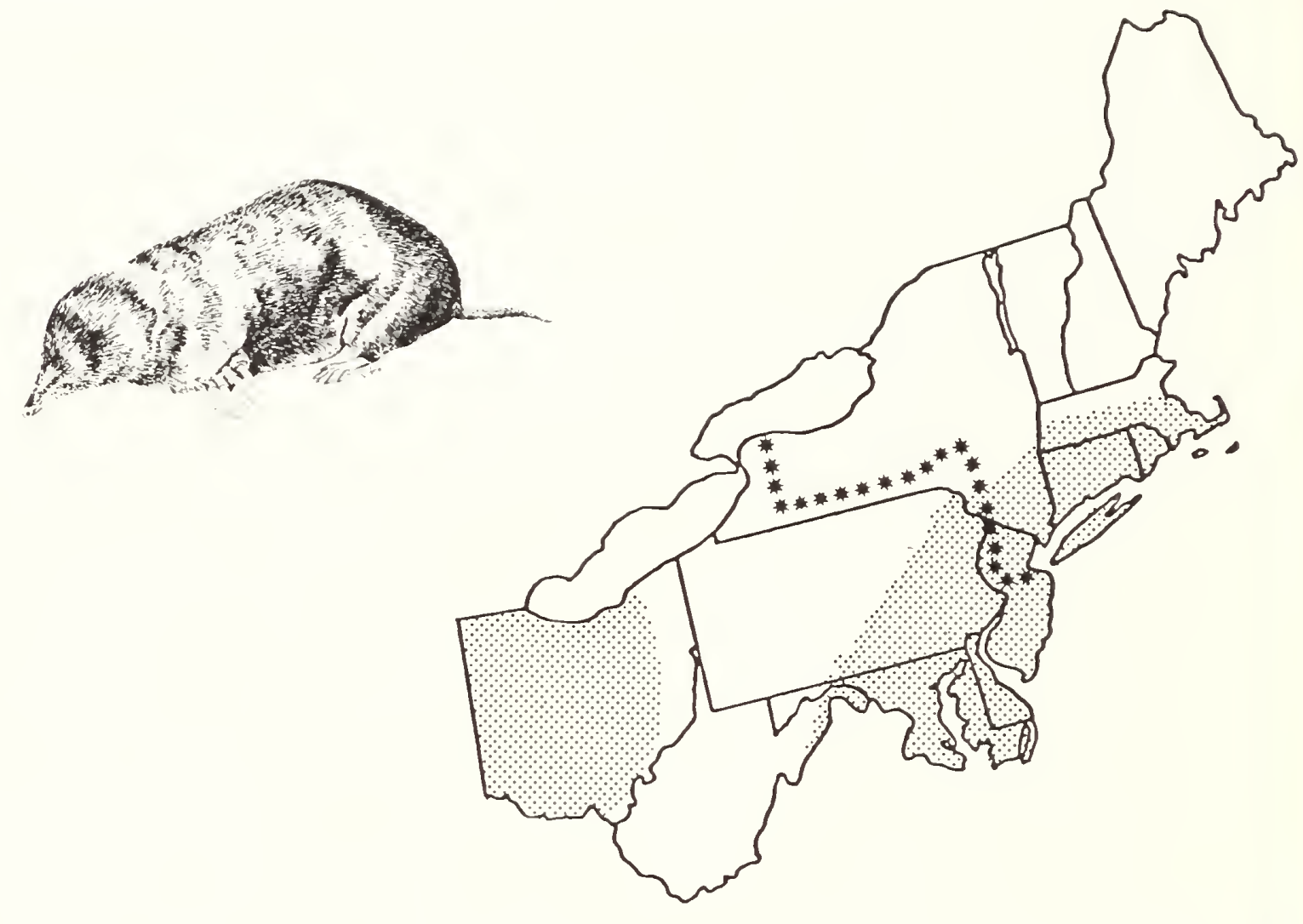

Range: Massachusetts west to Wyoming south to central Texas and the Gulf of Mexico.

Relative abundance in the Northeast: Locally common

Habitat in the Northeast: Pastures, meadows, lawns, and less often in open woodland, in loamy or sandy soils that permit easy digging. often in moist (not wet) bottomlands where earthworms are plentiful.

Special habitat requirements: Soft moist soils containing earthworms.

Reproduction

Age at sexual maturity: 1 year

Breeding period: March and April

Gestation period: 42 to 45 days

Young born: Late April or May

Litter size: 2 to 5

No. 1itters/year: 1

Home range: Average area $7,433 \mathrm{~m}^{2}(0.74 \mathrm{ha})$ for seven moles in Kentucky [four males averaged $10,898 \mathrm{~m}^{2}(1.09 \mathrm{ha})$; three females averaged $\left.2,812 \mathrm{~m}^{2}(0.28 \mathrm{ha})\right]$ (Harvey 1967). 
Sample density: Density of 3 moles/acre (7.4/ha) in large areas during summer. Other times of the year 1 mole/acre $(2.5 / \mathrm{ha})$ in Missouri (Leftwich 1972).

Food habits: Mainly eats earthworms, beetles, grubs, ants, centipedes, millipedes, spiders, slugs. Occasionally eats small quantities of vegetable material (Godin 1977:38, Yates and Schmidly 1978).

Economic status: Non-game

Comments: Active throughout the year during a 11 hours of day and night except early morning and early evening (Harvey 1967). Digs tunnels just below surface or in dry or cold weather excavates deeper burrows 10 inches or more deep. Spends most of life below ground. Young are independent when about 1 month old (God in 1977:38).

Key natural history references: Arlton 1936, Harvey 1967, Yates and Schmidly 1978. 


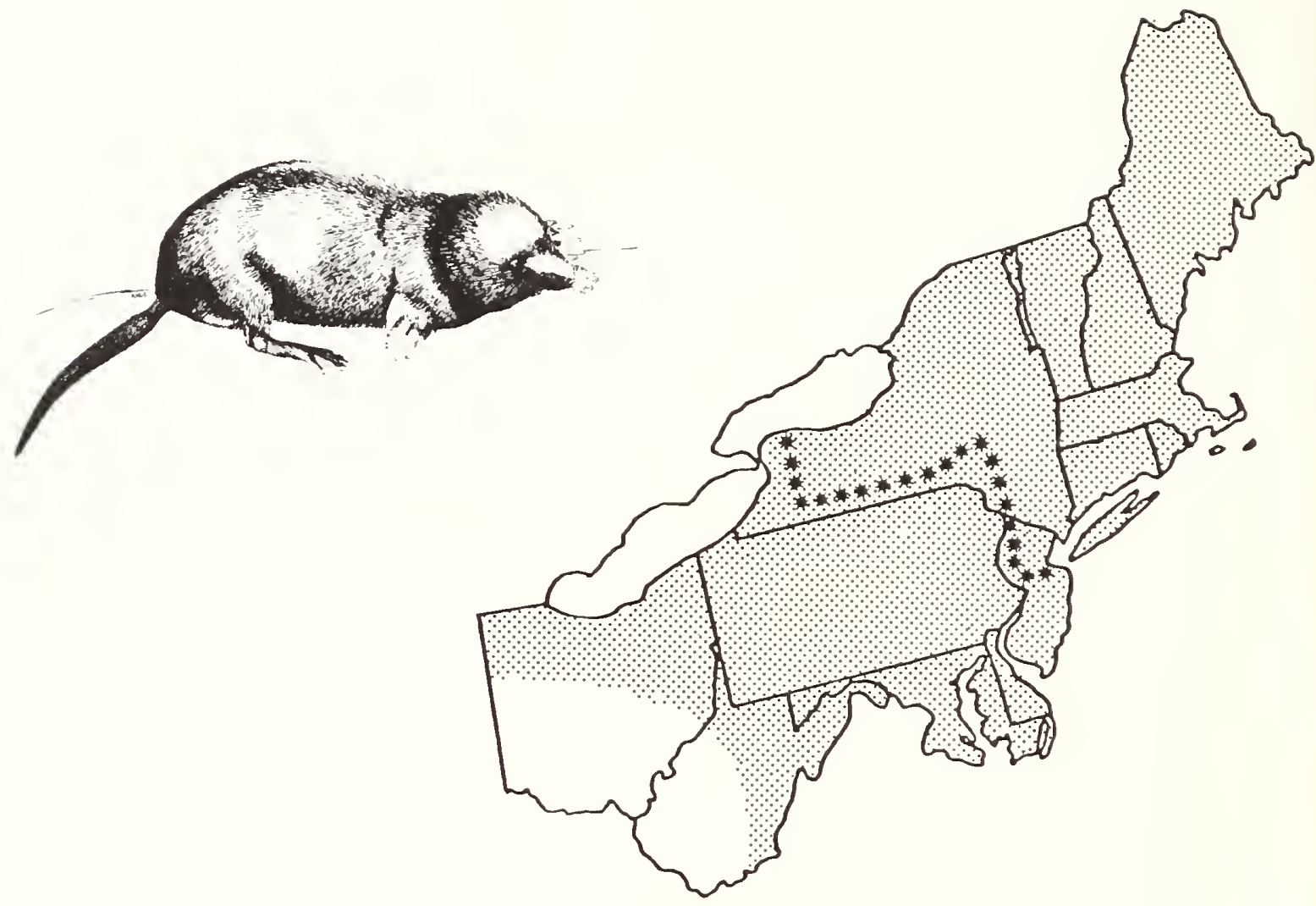

Range: Southern Labrador west to southwestern Manitoba, southeast through northern Ohio, south in the Appalachians through western North Carolina and along the coast to the northeastern corner of North Carolina.

Relative abundance in the Northeast: Common to uncommon

Habitat in the Northeast: Prefers low wet ground near bodies of water, wet meadows, occasionally wet spots in fields or low-lying woods. Has been found in mixed hardwood stands with dry soils near water.

Special habitat requirements: Wet, mucky humus.

\section{Reproduction}

Age at sexual maturity: 10 months

Breeding period: April and May

Gestation period: About 45 days

Young born: May and June

Litter size: 3 to 7 , average 5.4

No. litters/year:

Home range: Probably about 1 acre (0.4 ha) (Banfield 1974:36).

Sample density: 10 individuals/acre (24.7/ha) have been reported in late winter in New York (Eadie and Hamilton 1956). 
Food habits: Aquatic insects, earthworms, crustaceans, slugs, snails, isopods, small fish (occasionally), and small amounts of vegetable material. Forages above ground at night.

Economic status: Non-game

Comments: Excellent swimmer, spending much time in water. Usually lives in sma11 colonies (Eadie and Hamilton 1956). Active day and night throughout the year. Not uncommon on ground surface.

Key natural history references: Hamilton 1931b, Eadie and Hamilton 1956. 


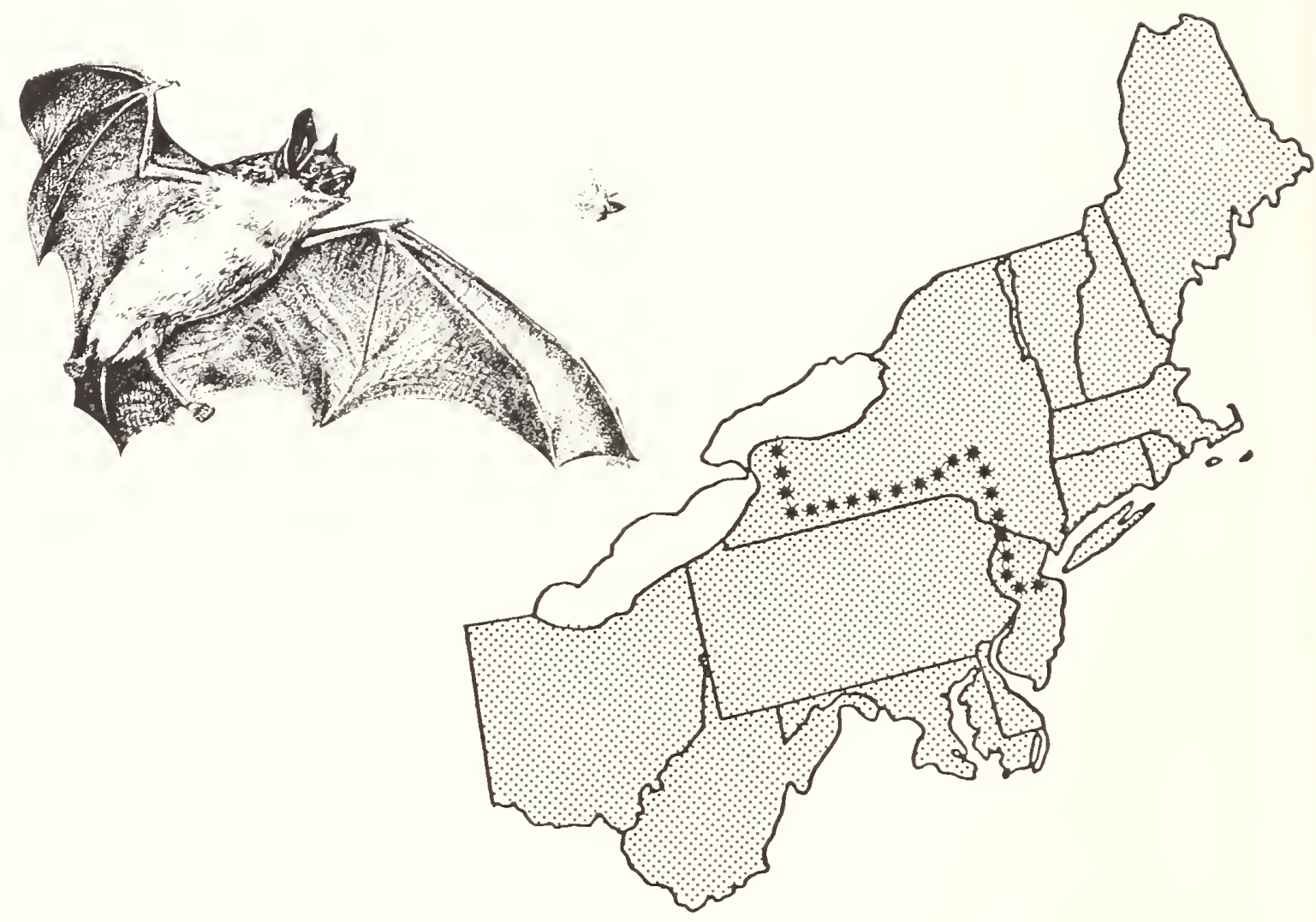

Range: Labrador west to southern Alaska south to Georgia (in the Appalachians) Arkansas and southern California.

Relative abundance in the Northeast: Common

Habitat in the Northeast: Breeds in caves in fall. Females seek attics and barns in spring for maternity colonies. Roosting habitat: caves, quarries, mine tunnels, hollow trees, buildings. Winter habitat: caves with constant $40^{\circ} \mathrm{F}$. temperatures and $80 \%$ relative humidity (Banfield 1974:42).

Special habitat requirements: Females seek dark, warm sites for maternity colonies. Males seek cooler daytime roosts, frequently in valleys near streams and marshes.

Reproduction

Age at sexual maturity: About 6 to 9 months for females, 1 year for males

Breeding period: Usually from September to October with fertilization delayed until spring Gestation period: 50 to 60 days (estimate) (Wimsatt 1945) Young born: Mid-June to early July

Litter size: 1

No. litters/year: 1 
Home range: Unknown

Sample densities: Summer density: average 26 bats $/ \mathrm{mi}^{2}\left(10 / \mathrm{km}^{2}\right)$ over an $8600 \mathrm{mi}^{2}\left(22,274 \mathrm{~km}^{2}\right)$ area served by a cave in southern Vermont. Winter density: In caves in southern Vermont - 300,000 \pm 30,000 (Davis and Hitchcock 1965).

Food habits: Congregate over water to drink and hawk for flying insects especially midges and mosquitos, but also beetles, moths and caddisflies (Anthony and Kunz 1977).

Economic status: Non-game

Comments: Breeding colonies of 12 to 1200 have been reported in Vermont. Females seek nursery sites in late April and disperse July to mid-September (Davis and Hitchcock 1965).

Key natural history references: Griffin 1940a, 1940b and 1945, Cagle and Cockrum 1943, Wimsatt 1945, Davis and Hitchcock 1965, Barbour and Davis 1969, Humphrey and Cope 1976. 


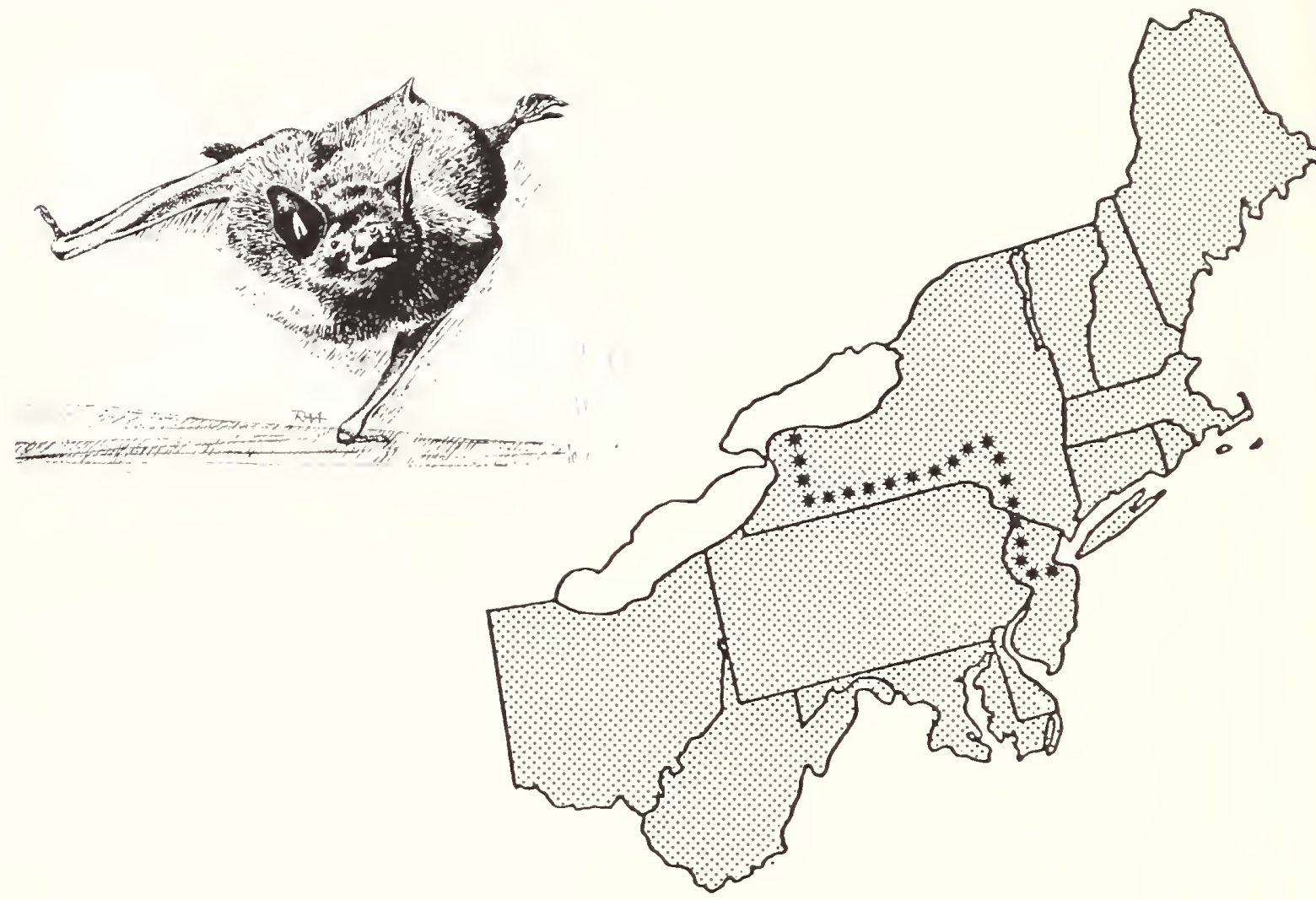

Range: Newfoundland and Nova Scotia west to Saskatchewan, south to Wyoming and northern Florida.

Relative abundance in the Northeast: Common to uncommon

Habitat in the Northeast: Females seek attics, barns and tree cavities for small nursery colonies. Both sexes roost singly or in small colonies in crevices under loose tree bark, in cliff walls, or in caves.

Special habitat requirements: For hibernation, Keen's myotis seeks caves or mine shafts with temperatures near $40^{\circ} \mathrm{F} .\left(4.5^{\circ} \mathrm{C}\right)$, high relative humidity (Banfield 1974:46) and calm air (Fitch and Shump 1979).

Reproduction

Age at sexual maturity: About 6 to 9 months for females, 1 year for males

Breeding period: September to October with fertilization delayed until spring

Gestation period: 50 to 60 days

Young born: Mid-June to early July

Litter size: 1

No. 1 itters/year: 1 
Home range: Unknown

Food habits: Little is known - probably similar to little brown myot is (Godin 1977:49). Forages over ponds and clearings and high along the forest edge (Cowan and Guiquet 1965). Stomachs of three individuals in Indiana contained assassin bugs, moths, butterflys, flys, leaf hoppers and other unidentified insects (Whitaker 1972).

Economic status: Non-game

Comments: Locally and irregularly distributed within its range. Several hundred individuals were observed hibernating in caves in Canada (Hitchcock 1949). Frequently found mixed with Myotis Zucifugus during hibernation.

Key natural history references: Barbour and Davis 1969, Banfield 1974, Godin 1977, Fitch and Shump 1979. 


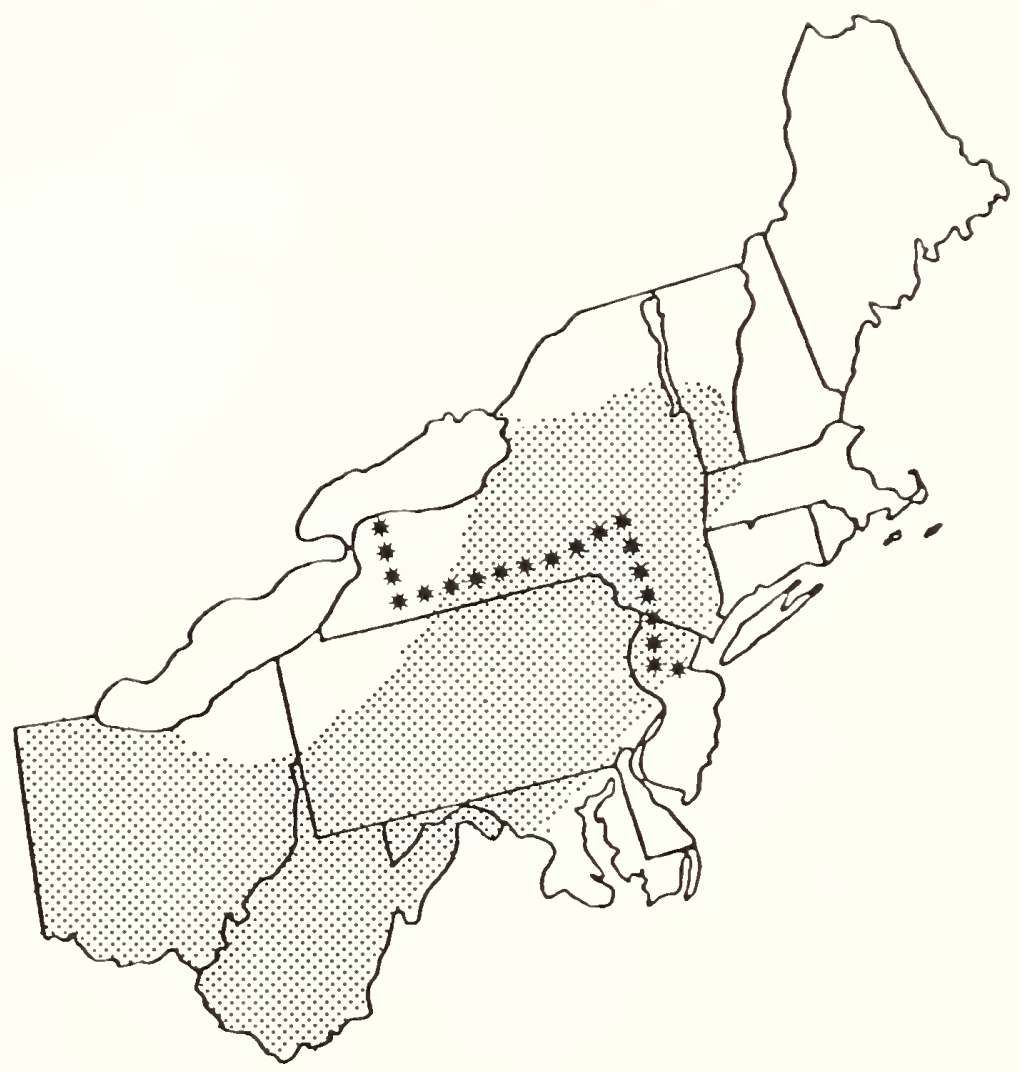

Range: Eastern New York and probably southern Vermont and western Massachusetts.

Relative abundance in the Northeast: Rare and endangered

Habitat in the Northeast: Favors limestone caves with pools of water.

Solitary females or small maternity colonies bear young in hollow trees or under loose bark. They cannot tolerate high temperatures of attics.

Special habitat requirements: Caves for hibernation that have cool, stable temperatures of $40^{\circ}$ to $46^{\circ} \mathrm{F}$. ( $4^{\circ}$ to $8^{\circ} \mathrm{C}$ ) throughout the winter (Humphrey 1978). Trees for nursery colonies.

Reproduction

Age of sexual maturity: About 6 months

Breeding period: Early October (Kentucky)

Gestation period: Unknown

Young born: Late June

Litter size: 1

Home range: Unknown 
Food habits: Forages in the foliage of crowns of trees 7 to $98 \mathrm{ft}$. (2 to $30 \mathrm{~m})$ tall along the shores of rivers and lakes and over floodplains (Humphrey et al 1977). Four stomachs examined in Indiana contained ichneumons, leaf hoppers, beetles and unidentified wasps (Whitaker 1972a).

Economic status: Non-game

Comments: Band recoveries revealed seasonal movement of up to 320 miles $(512 \mathrm{~km})$ (Hal1 1960). Hibernation period may last from mid-September to early June (averages mid-October to mid-Aprii). $97 \%$ of total population of Indiana myotis hibernates in four large caves in southern Indiana, I17inois, Missouri and Kentucky (Hal1 1962). Population has decreased by $28 \%$ in 15 years (Humphrey 1978). It may now be extinct in New England.

Key natura 1 history references: Hal1 1960 and 1962, Barbour and Davis 1969, Godin 1977. 


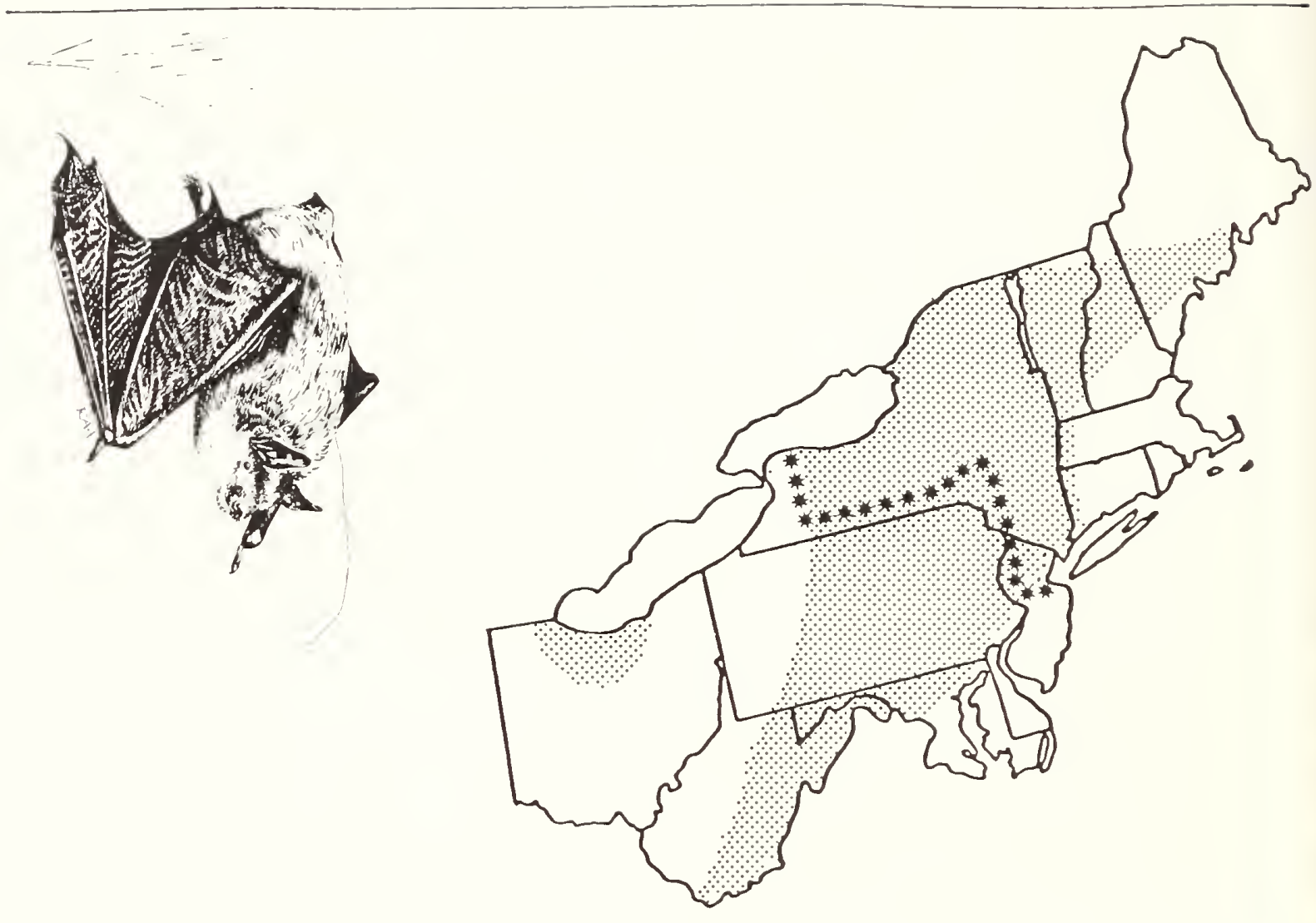

Range: Southeastern Canada west through the midwestern United States to eastern Washington south to Mexico, western Texas and northern Georgia.

Relative abundance in the Northeast: Uncommon

Habitat in the Northeast: In or near woodland in caves, mine tunnels, buildings, crevices in rocks. Maternity colonies have been observed in buildings (Hitchcock 1955).

Special habitat requirements: Tolerates cold, dry places for hibernation from mid-November to March (Barbour and Davis 1969:104).

Reproduction

Age at sexual maturity: Unknown

Breeding period: Unknown

Gestation period: Unknown

Young born: Single young found at the end of May in California; a pregnant female found in mid-July in Nebraska (Quay 1948)

Litter size: Probably 1

Home range: Unknown 
Food habits: Unknown. Probably similar to other myotids. Flies, bugs, beetles and ants found in stomachs of two specimens (Cockrum 1952:62).

Economic status: Non-game

Comments: Hibernates in cold, dry caves or mines from November to April (Pennsylvania). Associated with caves in the foothills of mountains up to 2000 feet $(610 \mathrm{~m})$ in coniferous woodlands (hemlock, spruce, white cedar) (Hitchcock 1949).

Key natural history references: Mohr 1936, Hitchcock 1949, Barbour and Davis 1969, Banfield 1974, Godin 1977. 
Silver-haired bat

Chiroptera

Lasionycteris noctivagans

Vespertilionidae
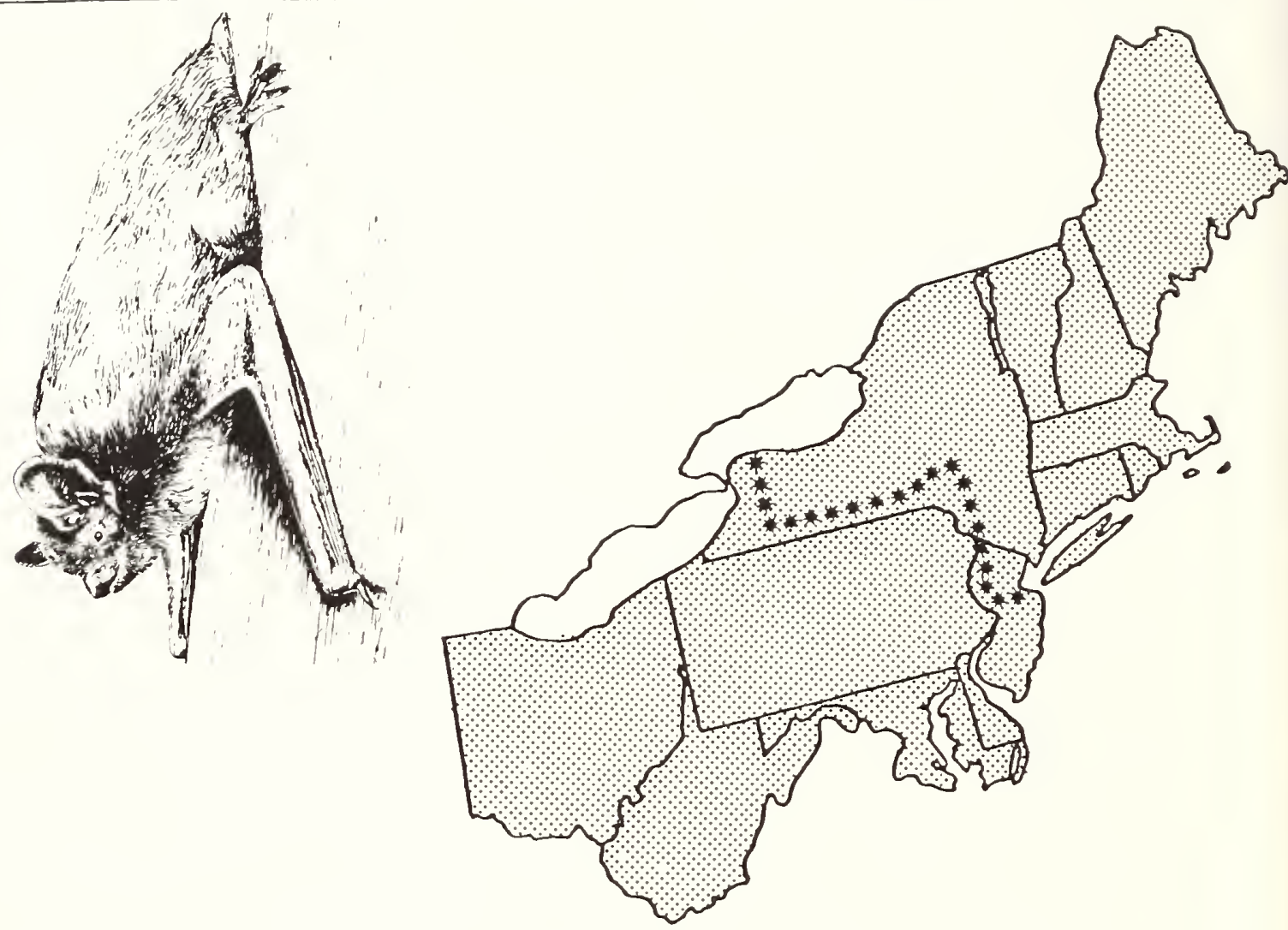

Range: Southern Canada west to southern Alaska south to central California central Texas and South Carolina.

Relative abundance in the Northeast: Uncommon to rare

Habitat in the Northeast: Forested areas near lakes or streams. Roosts in foliage of trees, in tree cavities and under loose bark as well as in buildings or caves. Frequently found in coniferous forests of mountains.

Special habitat requirements: Dead trees with loose bark or cavities for summer roosting sites, water courses.

Reproduction

Age at sexual maturity: First summer

Breeding period: Late September with delayed fertilization Gestation period: 50 to 60 days (Druecker 1972)

Young born: June or July

Litter size: 2 (occasionally 1)

No. litters/year: I

Home range: Unknown 
Food habits: Feeds among trees and over ponds and streams of ten Tess than 20 feet above surface; may prefer emerging aquatic insects (Banfield 1974:54).

Economic status: Non-game

Comments: Solitary in summer. Sexes remain separated except during breeding period. Migrates to southern parts of range, generally hibernates under loose bark or in tree cavities or buildings. Erratic in abundance throughout its wide range.

Key natural history references: Barbour and Davis 1969, Banfield 1974, Godin 1977. 

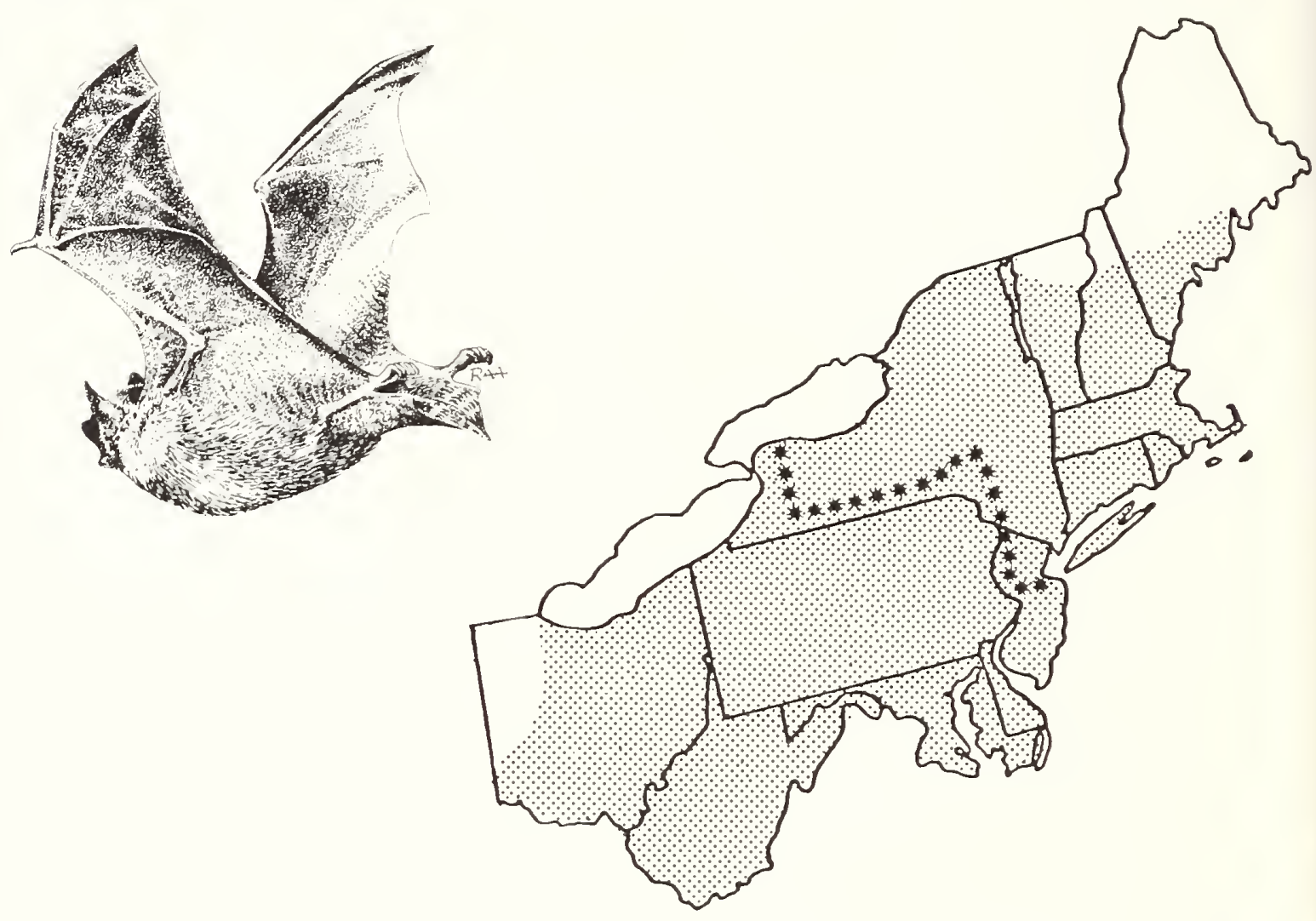

Range: Southeastern Canada west to Minnesota, south to eastern Mexico and Central America. Absent from northern New England, Michigan and southern Florida.

Relative abundance in the Northeast: Uncommon to rare

Habitat in the Northeast: Open woods near water, crevices in cliffs, buildings, caves. Avoids deep woods. Commonly roosts in trees during summer days.

Special habitat requirements: Warm, draft free, damp sites for hibernation (Banfield 1974:57), open woods (Godin 1977:54).

Reproduction

Age at sexual maturity: Probably first summer

Breeding period: October to November and frequently in early spring

Gestation period: About 45 days (Ha11 1956:3)

Young born: Late June to mid-JuTy

Litter size: Usually 2

Home range: Believed to feed within a radius extending at least 5 miles $(8 \mathrm{~km})$ from roosting site. 
Food habits: Usually solitary feeder. Prefers to feed over rivers, pastures (if large trees are nearby) and high in bordering trees in search of flies, beetles, ants, bugs, moths, wasps (Banfield 1974:57, Godin 1977:54). Leaf hoppers are important food (Whitaker 1972a).

Economic status: Non-game

Comments: Selects warm draftless spots for hibernation (mid-October to May) (Banfield 1974:57) in caves, mines and rock crevices (Godin 1977:54). Usually hangs singly or in pairs.

Key natural history references: Hal1 1956, Davis and Mumford 1962, Barbour and Davis 1969, Banfield 1974. 

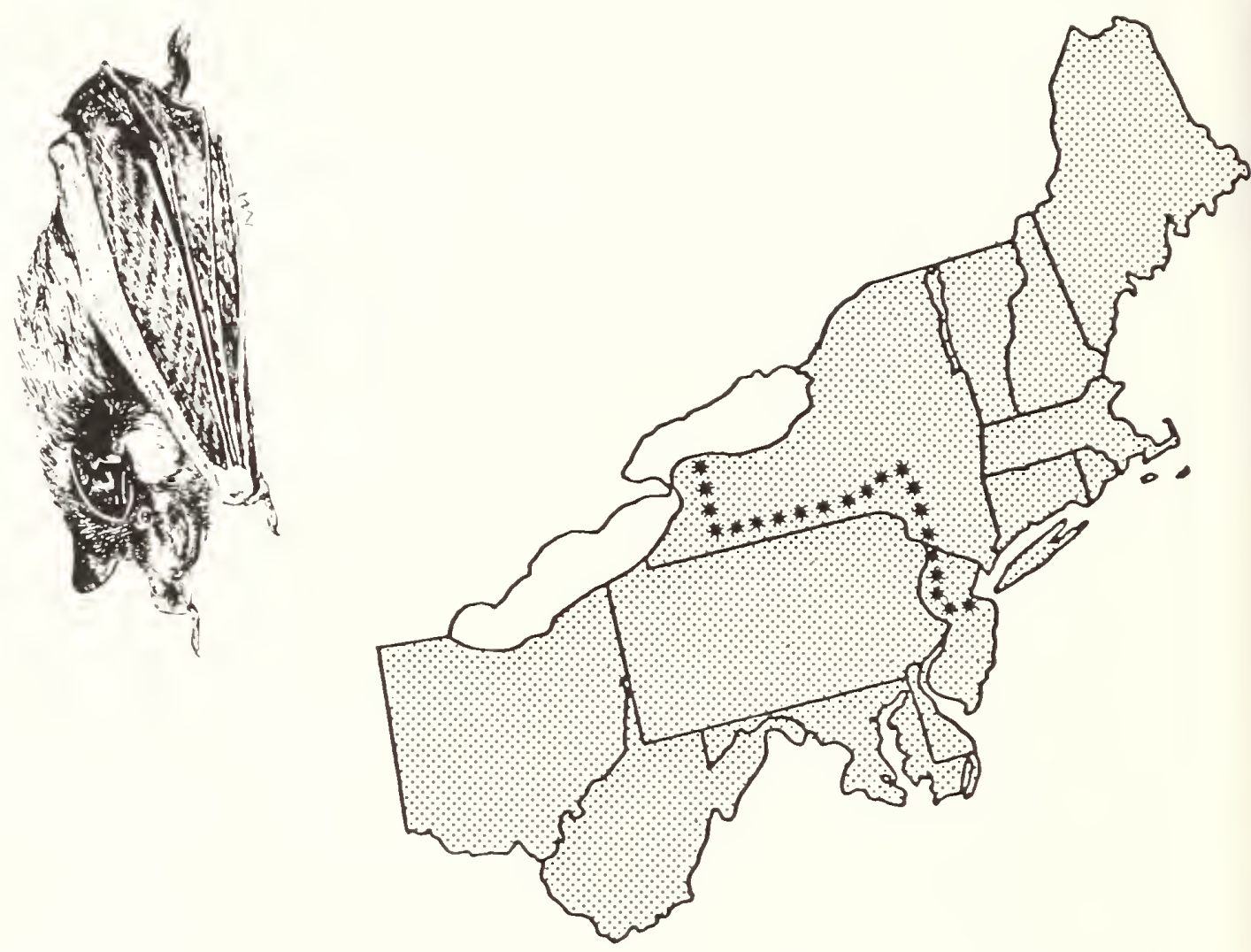

Range: Southern Canada west to Alaska south to northern Florida and South America.

Relative abundance in the Northeast: Common

Habitat in the Northeast: Buildings, bridges, tunnels, hollow trees, wooded areas; seldom roosts in caves in summer and avoids hot attics. Common around coastal areas.

Special habitat requirements: Appears to require cold, dry areas of caves or buildings for hibernation (Hitchcock 1949).

Reproduction

Age at sexual maturity: Females: first autumn

Males: 1 year

Breeding period: September through March. Peak: September.

Fertilization occurs in April.

Gestation period: About 2 months

Young born: June

Litter size: Usually 2 in the East, 1 in the West

No. 1itters/year: 1

Home range: Probably travels less than 30 miles $(48 \mathrm{~km}$ ) from birthplace (Barbour and Davis 1969:127) and often uses same site for summer roosting and hibernation. 
Food habits: Beetles, wasps, flies, bugs and other flying insects (Hamilton 1933a). Beetles comprised the highest percentage of diet in Indiana (Whitaker 1972a). Individuals may use the same feeding ground each night (Barbour and Davis 1969:121).

Economic status: Non-game

Comments: Hibernation begins in November. Nursery colonies are relatively small, usually with a maximum of 700 individuals (Mills et al 1975). In New England nursery colonies seldom exceed 200 individuals.

Key natural history references: Phillips 1966, Barbour and Davis 1969, Mil1s et al 1975, Godin 1977. 


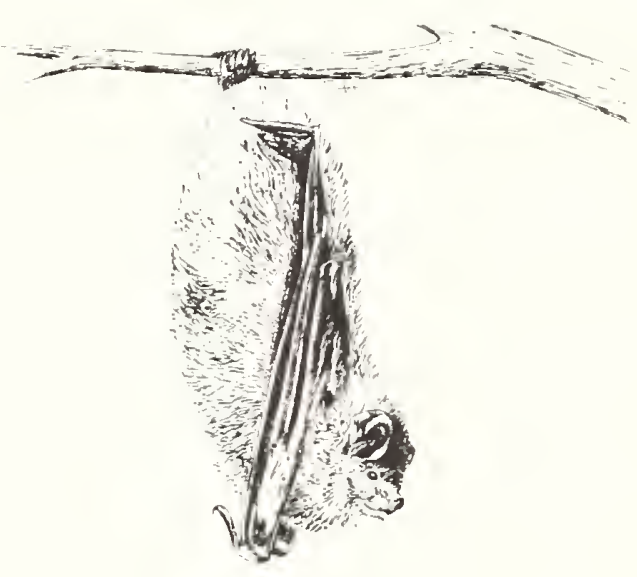

Range: Southern Canada from Nova Scotia west to British Columbia south to Texas and northern Florida, also northern California south.

Relative abundance in the Northeast: Uncommon to rare

Habitat in the Northeast: Wooded areas where it roosts in trees 5 to 40 feet $(1.5$ to $12.2 \mathrm{~m}$ ) above ground (McClure 1942). Solitary except females with young. Rarely found in buildings or caves except during migration. In Maryland, bats favored deciduous woodlands (Paradiso 1969:54). Greatest numbers were found along fence rows and forest edges, in roosting areas open only from below (Constantine 1966). Most active over water early in evening (Kunz 1973).

Special habitat requirements: Possibly trees for roosting.

Reproduction

Age at sexual maturity: Second summer

Breeding period: August to October, fertilization occurs in spring

Gestation period: 60 to 70 days

Young born: Late May to early July, mid-June in Indiana

(Whitaker and Mumford 1972) and Iowa (Kunz 1971)

Litter size: 1 to 5 , average 2.3

No. 1 itters/year: 1 
Home range: Unknown, however known to forage 600 to 1,000 yards

$(546$ to $910 \mathrm{~m})$ from day roosts (Jackson 1961:95).

Sample density: 1 individual/acre $(2.5 / \mathrm{ha})(n=150)$ in Iowa

(McCTure 1942).

Food habits: Feeds at height of tree foliage to ground, sometimes in pairs and often repeatedly follows the same route about

100 yards (91 m) in length (Burt and Grossenheider 1976:37).

Eats moths, beetles, bugs, flies, crickets and other insects.

Economic status: Non-game

Comments: Migrates south in autumn wintering from Maryland and Washington, D.C. to the Gulf States (Paradiso 1969:55, Banfield 1974:62).

Key natural history references: McClure 1942, Layne 1958, Barbour and Davis 1969, Godin 1977. 

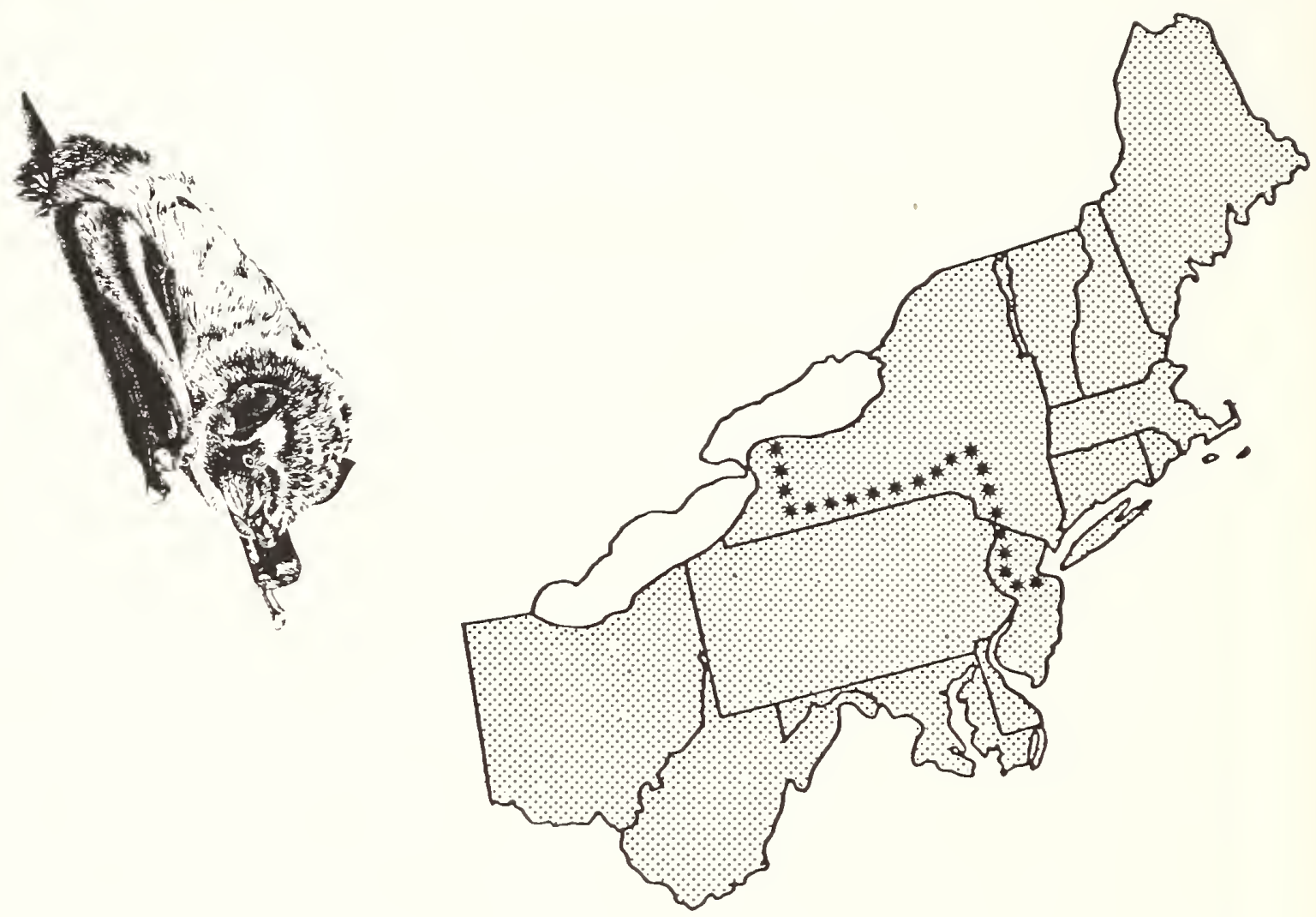

Range: Southern Canada south to central Florida and South America.

Relative abundance in the Northeast: Rare

Habitat in the Northeast: Wooded areas where it roosts 10 to 15 feet (3 to $4.5 \mathrm{~m}$ ) above ground in trees (Constantine 1966). Prefers coniferous forests but also uses deciduous woods and woodland edges, hedgerows and trees in city parks (Godin 1977:60).

Special habitat requirements: Forest edge.

Reproduction

Age at sexua 1 maturity: Most become mature during first summer (Druecker 1972).

Breeding period: September to November. Peak: Early September. Gestation period: Believed to be about 90 days (Jackson 1961)

Young born: Mid-May to early July

Litter size: 1 to 4 , average 2

No. 1itters/year: 1

Home range: Feeding range may extend a mile $(1.6 \mathrm{~km})$ or more from roosting site (Paradiso 1969:58). 
Food habits: Forages for insects over lakes and forest clearings (Banfield 1974:64). Out of 139 hoary bats examined in New Mexico, 136 contained moths, up to 25 individuals per bat (Ross 1967). Has been seen attacking pipistrelles in New York (Bishop 1947) and in California (Orr 1950).

Economic status: Non-game

Comments: Largest of eastern bats. Females do not form maternity colonies. Sexes separate when young are born and remain segregated most of summer (Godin 1977:61). Migrates in waves to southern United States and Central America. Individuals have been found in the North during the winter months (Whitaker 1967).

Key natural history references: Seton 1909, Barbour and Davis 1969, Bogan 1972, Godin 1977. 


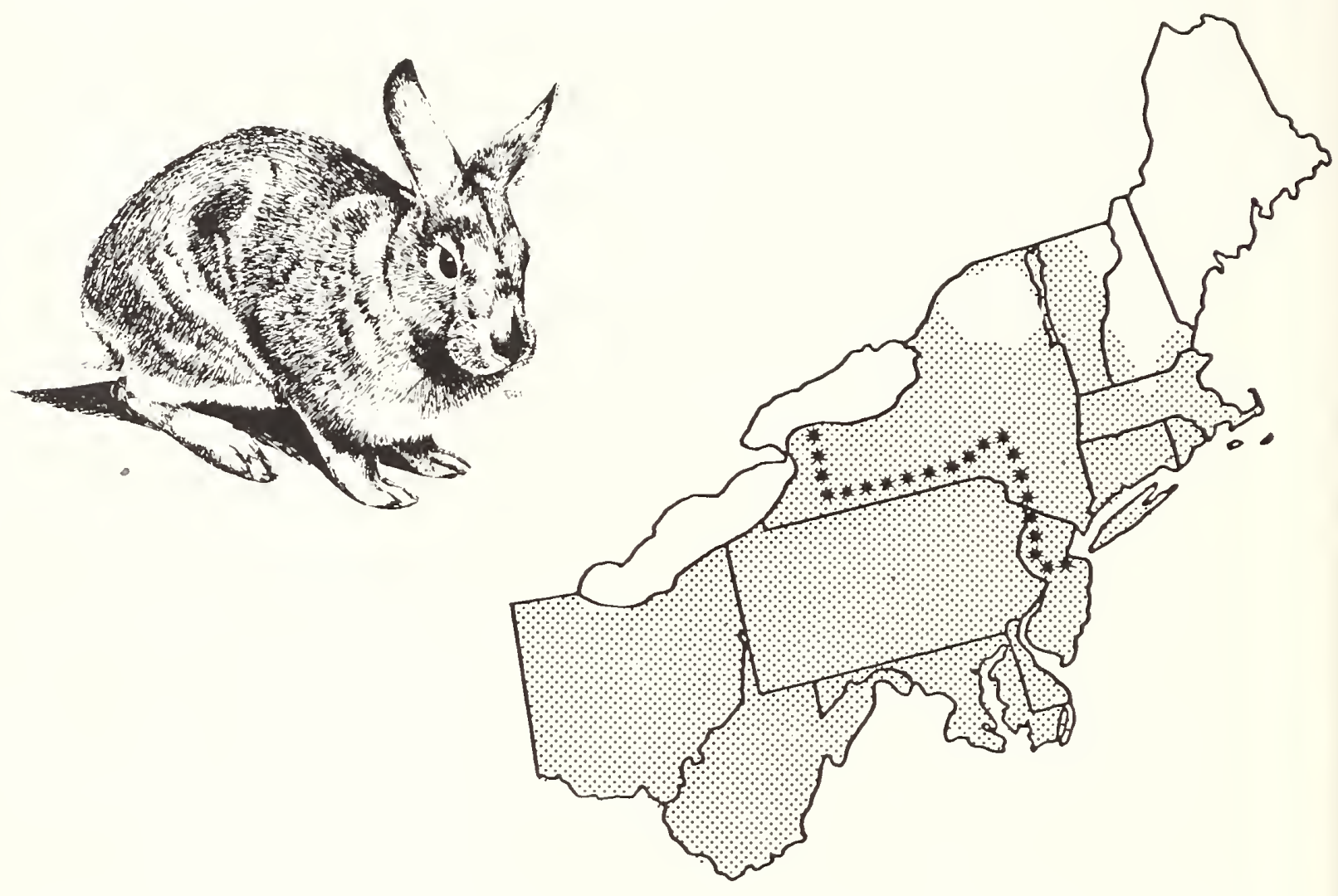

Range: Eastern U.S. including extreme southern Canada south through eastern Mexico and parts of Central America. Is spreading into New Hampshire at the expense of the New England cottontail (E. Francq, pers. comm. 12/79).

Relative abundance in the Northeast: Abundant

Habitat in the Northeast: Farmlands, pastures, fallow fields, open woodlands, thickets along fence rows and stone walls, edges of forests, swamps and marshes, suburban areas with adequate food and cover. Avoids dense woods.

Special habitat requirements: Brush piles, stone walls, dens or burrows for year-round protection from storms and cold weather. Herbaceous and shrubby cover.

Reproduction

Age at sexual maturity: 2 to 3 months. Most females breed the first spring following birth.

Breeding period: March to September. Peak: Apri1 to August. Gestation period: 26 to 32 days

Young born: March to September. Young disperse at about 7 weeks.

Litter size: 3 to 8 , typically 5 or 6

No. litters/year: 3 to 4 
Home range: Sizes range from about a half-acre to 40 acres $(0.2$ to 16.2 ha) or more (Godin 1977:68). Average 1.4 acres (0.57 ha) for adult males and 1.2 acres (0.48 ha) for adult females in Massachusetts (McDonough 1960). Approximately 8 acres (3.2 ha) (Banfield 1974:77).

Sample densities: 0.46 animal/acre $(1.1 / \mathrm{ha})$ on 75 acre $(30.4 \mathrm{ha})$ plot in Iowa during month of June, increasing to $1.65 /$ acre $(4 / \mathrm{ha})$ in August, followed by a drop to $0.89 /$ acre $(2.2 / \mathrm{ha})$ in October (Banfield 1974:77).

Food habits: Crepuscular and nocturnal feeder. Most feeding takes place 2 to 3 hours after sunrise and within the hour following sunset. Summer foods: tender parts of grasses and herbs. Winter foods: bark, twigs and buds of shrubs and young trees such as maple, birch and oak. Reingests fecal pellets.

Economic status: Game

Comments: The eastern cottontail was introduced into New England in the late $1800^{\prime} s$. Female does not dig a burrow - uses abandoned woodchuck hole or digs a shallow nest in soft earth that is well-concealed by surrounding vegetation. Active throughout the year.

Key natural history references: Dalke and Sime 1938, Beule and Studholme 1942, Haugen 1942, Chapman et al 1977. 


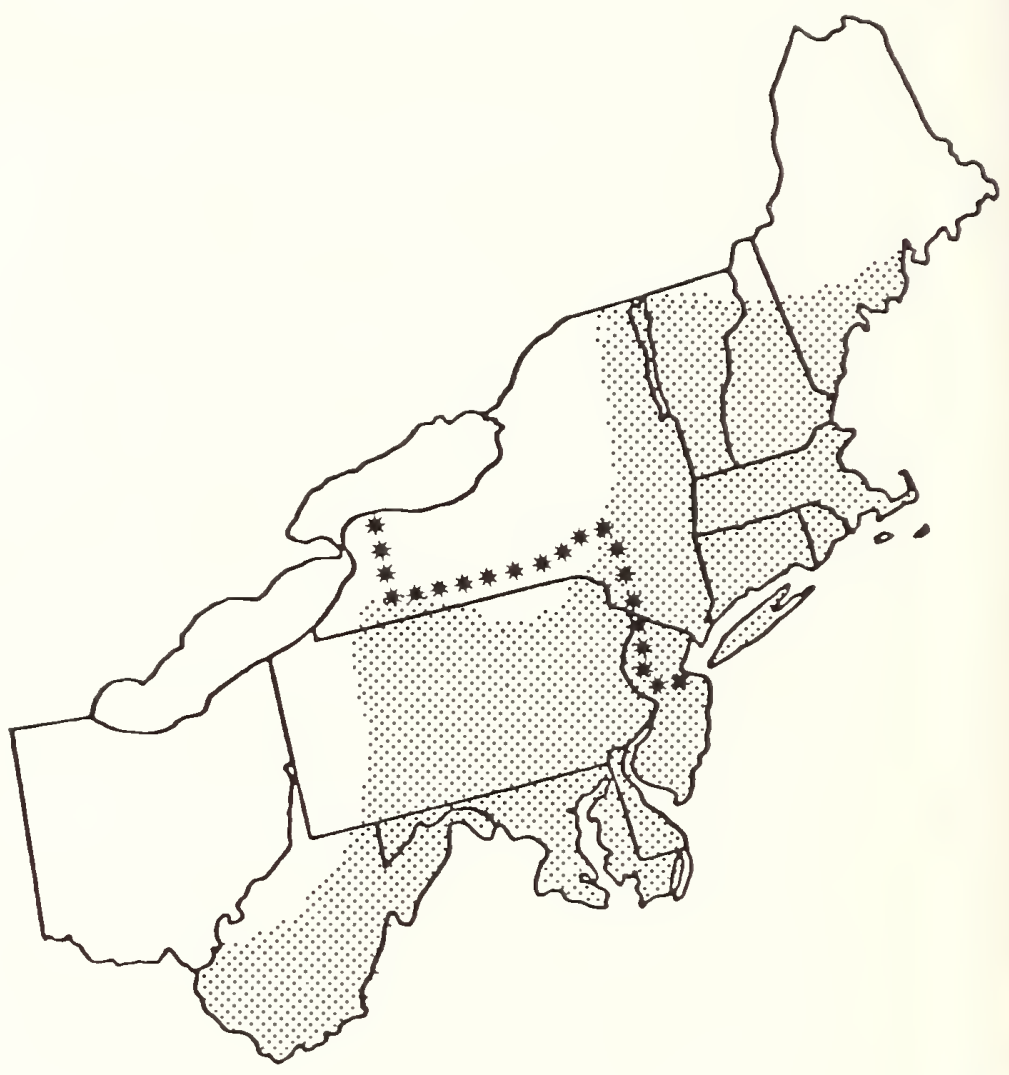

Range: Central and southern New England south through eastern New York, Pennsylvania, northern New Jersey and the Appalachian Mountains (to slightly above 4000 feet, $1220 \mathrm{~m}$ ) to Alabama.

Relative abundance in the Northeast: Uncommon (southern New England) to rare (New Hampshire and Vermont).

Habitat in the Northeast: Brushy areas, open woodlands, swamps, mountains (Fay and Chandler 1955). Reported at beaches, saltmarshes and open land (Johnston 1972). Also in young woods associated with clearcuts and in hay fields or other grasslands.

Special habitat requirements: Young woodlands with thick cover. Seldom ventures far from dense cover (Pringle 1960).

Reproduction

Age at sexual maturity: Probably during second year (Dalke 1942:73)

Breeding period: March to September. Peak: March to July (Chapman et al 1977)

Gestation period: 28 days (Dalke 1942:70)

Young born: End of March to early April extending through July (Pringle 1960:14)

Litter size: 3 to 8 , average 5

No. 1itters/year: 2 or 3 
Home range: 0.5 to 1.8 acres (0.2 to $0.7 \mathrm{ha}$ ) (McDonough 1960).

Average 3 acres ( $1.2 \mathrm{ha}$ ) for 17 females and 8.3 acres $(3.4$

ha) for 10 males in swamp and upland woods (Dalke 1942:42).

Food habits: Summer: grasses and herbs. Winter: seedlings, bark, twigs, buds (prefers maple and oak). Reingests fecal pellets.

Food preference related to availability.

Economic status: Game

Comments: Crepuscular and nocturnal feeder.

Key natural history references: Dalke 1942, Fay and Chandler 1955, McDonough 1960, Pringle 1960, Chapman et a) 1977.

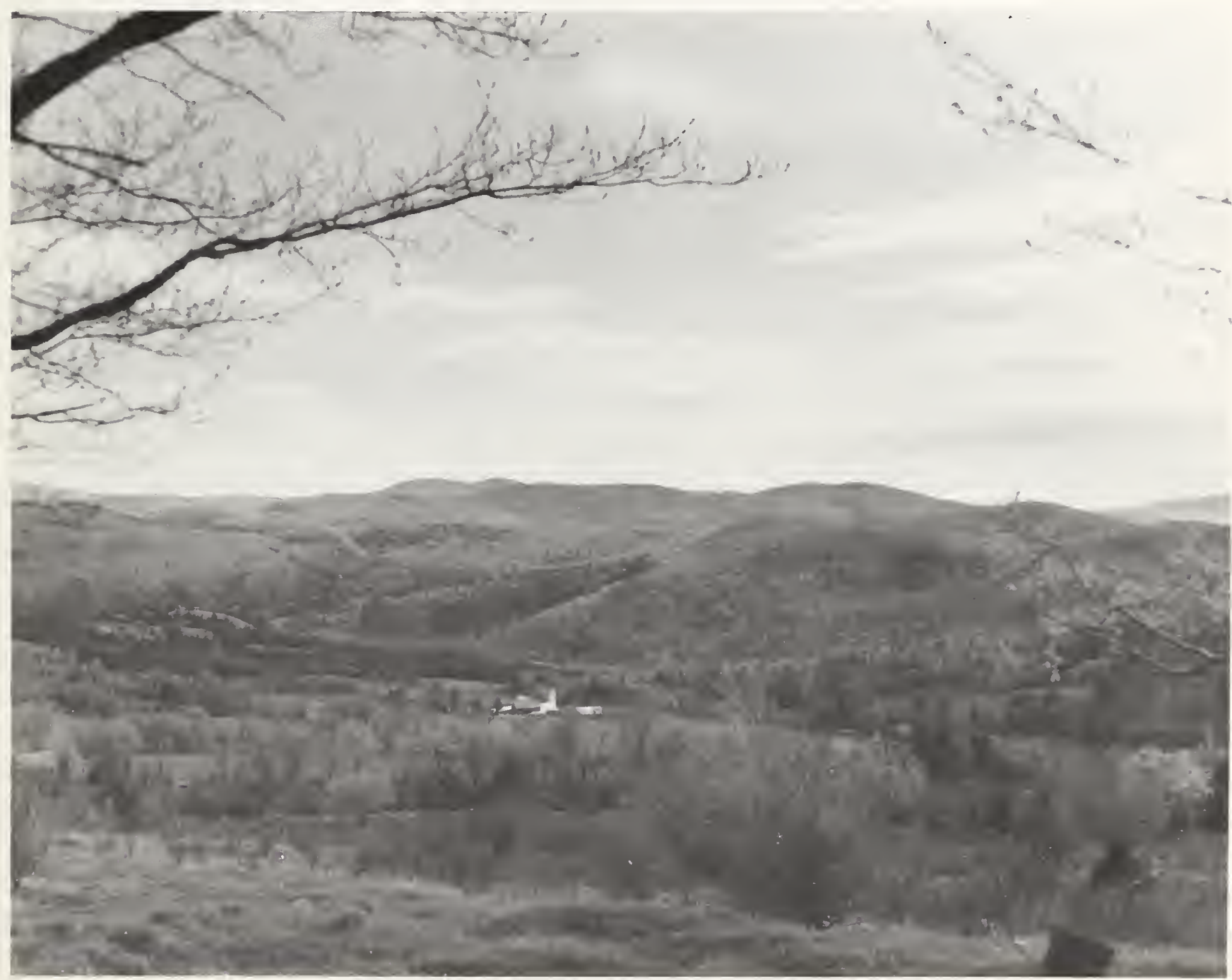




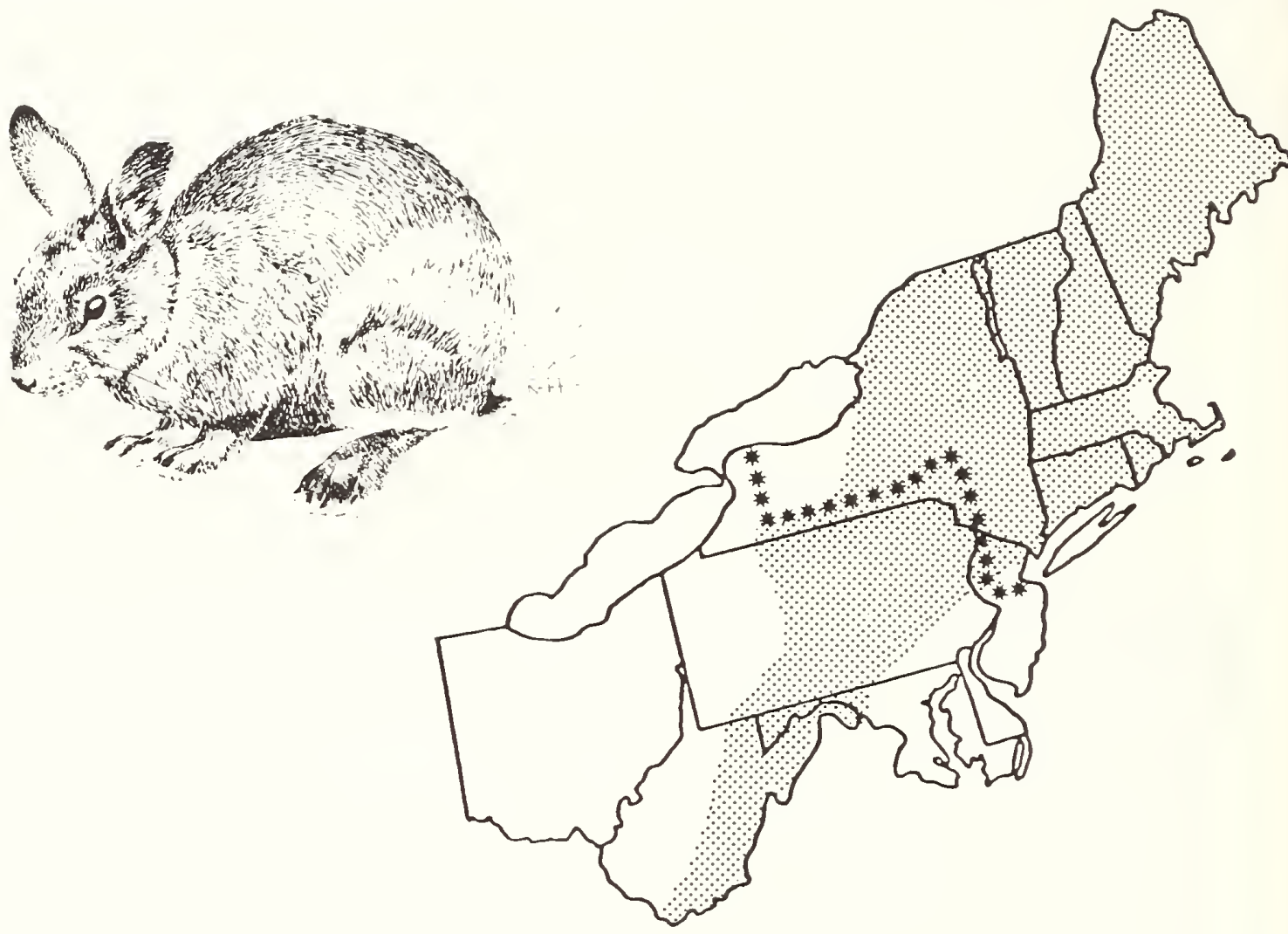

Range: Newfoundland west to Alaska south along the northern U.S. border, and south in the Sierras, Rockies and Appalachians.

Relative abundance in the Northeast: Common in suitable habitat.

Habitat in the Northeast: Deciduous, coniferous and mixed woodlands (1ess often deciduous) with dense brushy understory, coniferous swamps, cut-over areas, burns, nearly all types of forests, but favors second growth poplar-birch in vicinity of conifers.

Special habitat requirements: Dense brushy cover.

Reproduction

Age at sexual maturity: Young mature during the spring

Breeding period: March to July

$$
\text { following birth }
$$

Gestation period: About 37 days

Young born: May to August

Litter size: 1 to 6 , average 3

No. 1itters/year: 1 or 2, occasionally 3

Home range: Probably about 10 acres (4 ha) (Burt 1957). About 25 acres

(10.1 ha) for adult males and 19 acres ( 7.7 ha) for adult females

on an island in northwestern Montana (Adams 1959). Daily ranges

for both sexes were about 4 acres ( $1.6 \mathrm{ha}$ ) in mixed woodland -

old field habitat in Canada (Bider 1961). 
Sample density: Populations follow 10 or 11 year cycles with densities known to vary from $1 / \mathrm{mi}^{2}\left(0.4 / \mathrm{km}^{2}\right)$ to several hundred/square mile.

Food habits: Mainly crepuscular and nocturnal. Summer: succulent vegetation such as clover, grasses and ferns. Winter: twigs, buds and bark of small trees and seedlings such as alder and balsam. Reingests fecal pellets.

\section{Economic status: Game}

Comments: Pelage turns white in winter following fall molt and returns to brown after spring molt. Young are precocious at birth (born with dense fur and open eyes).

Key natural history references: Aldous 1937, Bider 1961, Dodds 1965, Godin 1977. 


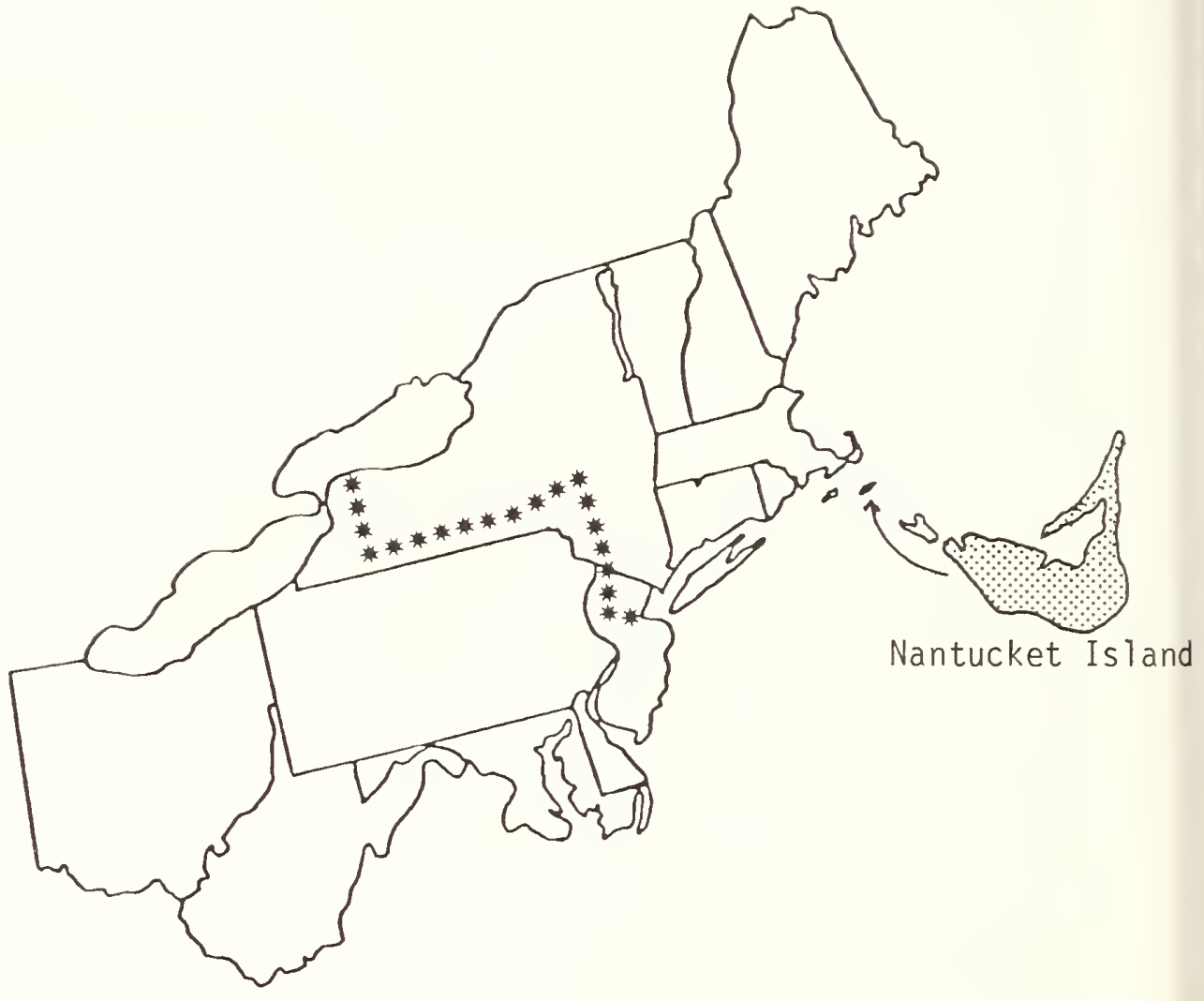

Range: Western United States. Introduced on Nantucket Island in Mass.

Relative abundance in the Northeast: Common on Nantucket Island.

Habitat on Nantucket Island: Sparsely vegetated areas, dunes, cultivated and fallow fields. Scratches out a shallow depression under protective vegetation for nesting.

Special habitat requirements: Open land with sparse low vegetation.

Reproduction

Age at sexual maturity: Females mature during second season (Haske11 and Reynolds 1947)(California). Males at 6 to 7 months (Bronson and Tiemeier 1958) (Kansas).

Breeding period: January to July (southeast Idaho). Shorter breeding seasons in regions with more severe winter climates.

Gestation period: 43 days (Haskell and Reynolds 1947). About 30 days in Kansas (Bronson and Tiemeier 1958).

Young born: Unknown in East

Litter size: 1 to 6 , typically 2 to 4

No. 1itters/year: Average 4 litters/year in the Midwest and Idaho. In California as population density increases, the length of the breeding period, the number of females pregnant, and the number of young produced decreases (French 1964). 
Home range: Most marked rabbits were found no further than 0.25 miles $(0.4 \mathrm{~km})$ from capture point (French et al 1965). Home range less than 40 acres (16.2 ha) (French et al 1965).

Sample density: Average 1.6 hares/linear mile $(1 / \mathrm{km})$ in southeastern Idaho (French et al 1965).

Food habits: Mainly crepuscular and nocturnal feeders. Food habits on Nantucket Island not known.

Economic status: Game

Comments: Little is known about the animal's life history on Nantucket Is land.

Key natural history references: Haskel1 and Reynolds 1947, Godin 1977. 


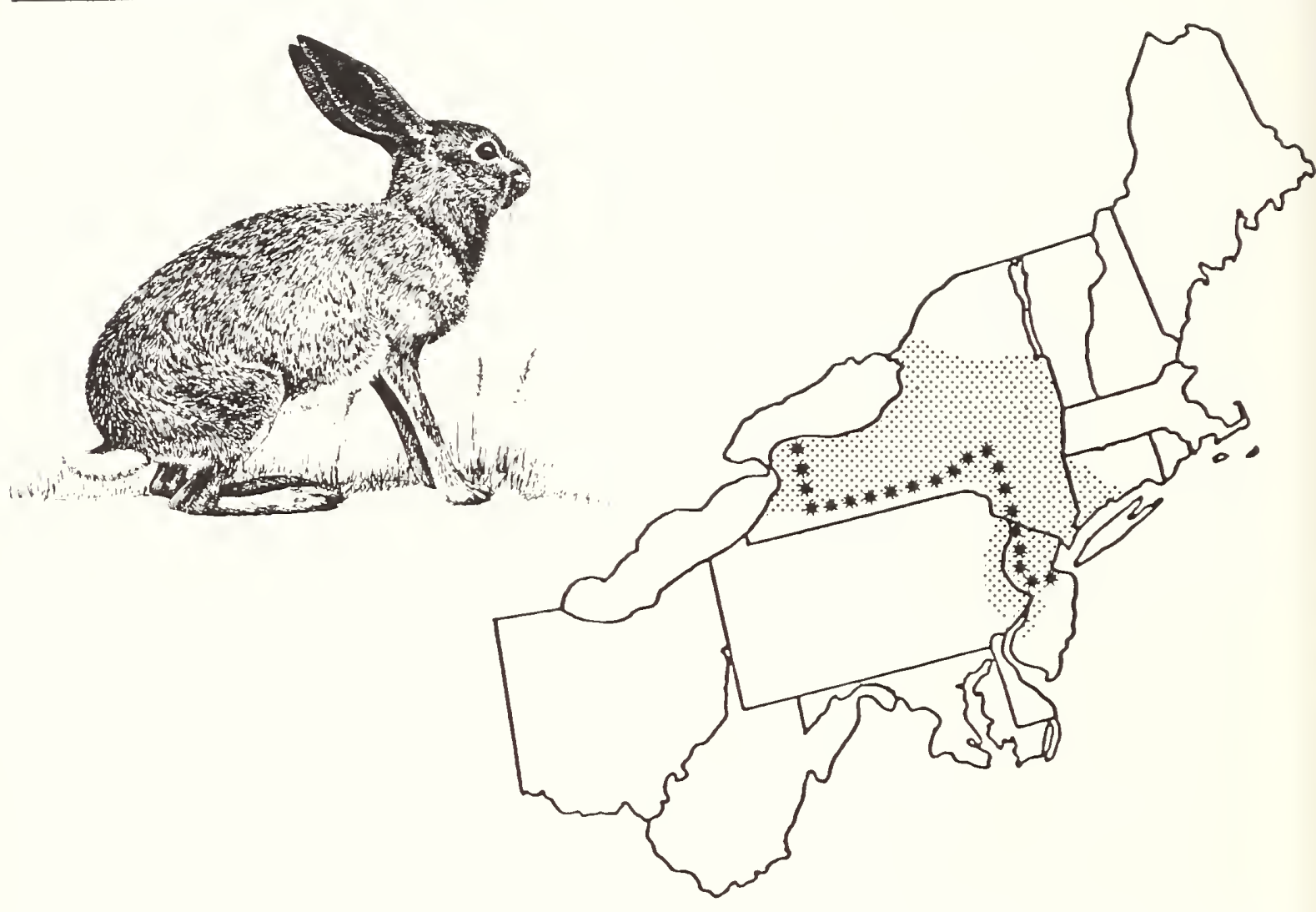

Range: Western Connecticut, eastern New York, eastern Pennsylvania and western New Jersey. Introduced to New York from Europe between 1890 and 1910.

Relative abundance in the Northeast: Probably not common

Habitat in the Northeast: Open country (mainly agricultural land) with low vegetation and rolling hills. Occasionally uses open woodlands with little ground vegetation.

Special habitat requirements: Open land.

Reproduction

Age at sexual maturity: Probably first spring following birth. Breeding period: January

Gestation period: About 42 days

Young born: March

Litter size: 1 to 3

No. litters/year: Unknown

Home range: $11 \mathrm{mi}^{2}\left(28.5 \mathrm{~km}^{2}\right)$ (Eabry 1970). About 12 acres (4.9 ha) (Banfield 1974).

Sample density: Average population density was about 25 hares/square mile $(10 / \mathrm{sq} . \mathrm{km})$ in Ontario with a potential density of 100 hares/ square mile (39/sq. km) under ideal conditions (Banfield 1974). 
Food habits: Summer: grass, clover, corn, fruits such as raspberries, apples, etc. Winter: buds, bark and twigs of young trees and seedlings. Reingests fecal pellets.

Economic status: Game

Comments: Builds no nest. Scrapes a hollow in ground near protective vegetation, rocks, etc.

Key natural history references: Dean and deVos 1965, Banfield 1974, Godin 1977. 


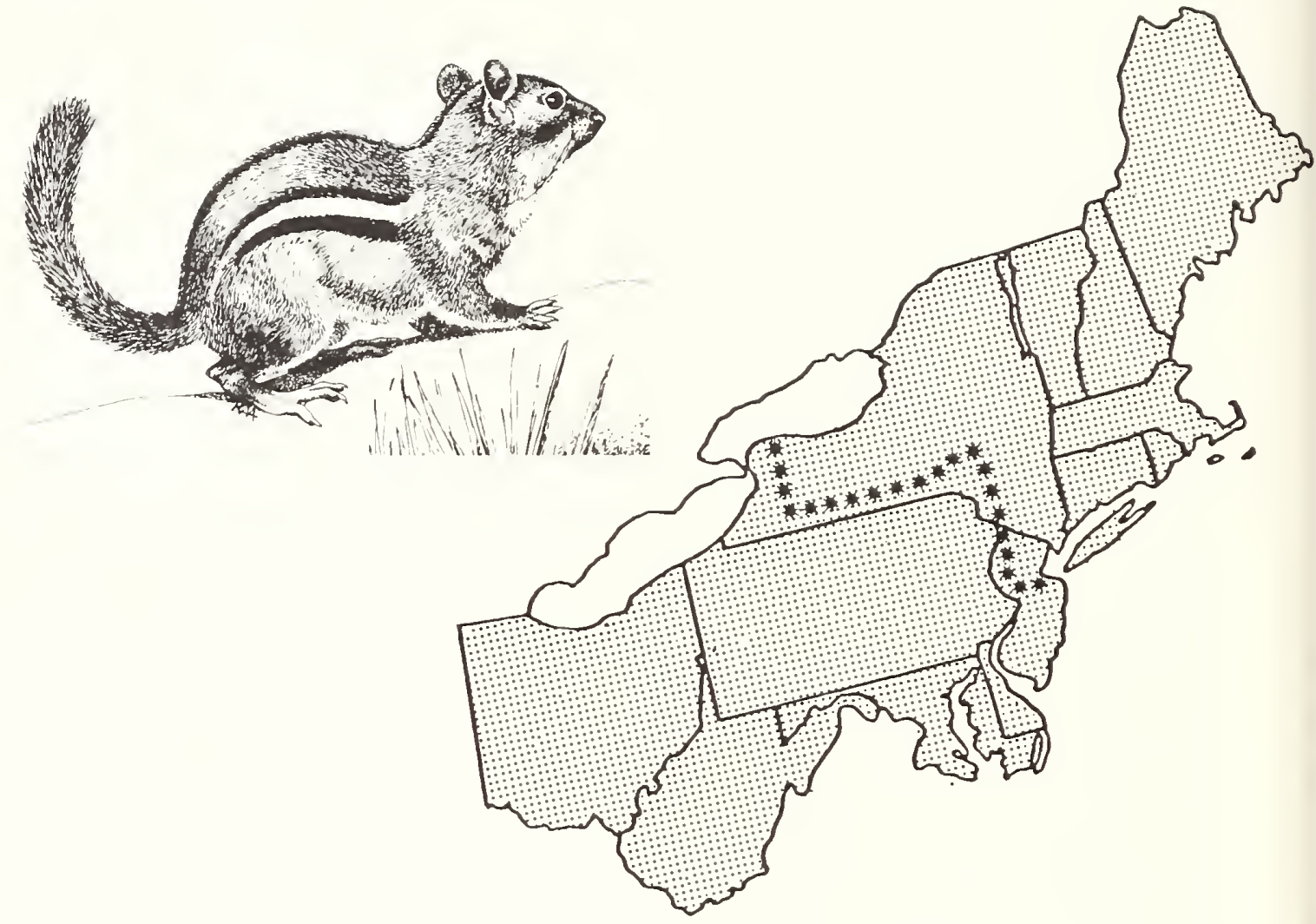

Range: Quebec west to Manitoba south through most of eastern U.S. to Louisiana and northwestern Florida. Absent from most of coastal plain.

Relative abundance in the Northeast: Common

Habitat in the Northeast: Edges or interiors of deciduous woodlands with abundant cover of undergrowth, old logs, stone walls. Semi-open brushlands with ample cover; rubbish heaps.

Special habitat requirements: Tree or shrub cover, elevated perches.

Reproduction

Age at sexual maturity: Females: 3 months (rarely) to 1 year Males: 7 months to 1 year

Breeding period: Two. Mid-March to early April and early July to early August

Gestation period: About 31 days

Young born: Mid-Apri1 to mid-May and mid-July to mid-August Litter size: 1 to 8 , average 4 or 5

No. 1itters/year: 1 or 2

Territory: A female defended a 50 yard $(45.5 \mathrm{~m})$ radius surrounding the living quarters in oak-hickory woodland in Michigan (Burt 1940). Individuals maintain dominance in a core area that covers about $20 \%$ of home range (Ickes 1974). 
Home range: Less than 100 yards $(91 \mathrm{~m}$ ) in diameter (Burt 1957).

0.5 to 1.0 acre ( 0.2 to 0.4 ha) in northern hardwoods in the Adirondacks of New York (E1) iott 1978:9).

Sample densities: 2 individuals/acre (5/ha) at onset of breeding season increasing to 4 individuals or more/acre $(10+/ \mathrm{ha})$

at end of breeding season (Burt 1957). Up to 30 individuals/ acre (74/ha) in good habitats (Seton 1929). Varies geographically and temporally from 0.1 to 15.2 /acre $(0.3$ to $37.6 /$ ha) (Yerger 1953).

Food habits: Many kinds of seeds, fruits, nuts, bulbs, insects, meat and eggs. Feeds during daylight hours.

Economic status: Non-game

Comments: Hibernates but may become active for short periods in winter. Largely terrestrial. Den is located in underground tunnel system.

Key natural history references: Allen 1938, Burt 1940 and 1957 , Yerger 1953 and 1955, Forbes 1966, Elliott 1978, Yahner 1978. 
Woodchuck

Rodentia

Sciuromorpha

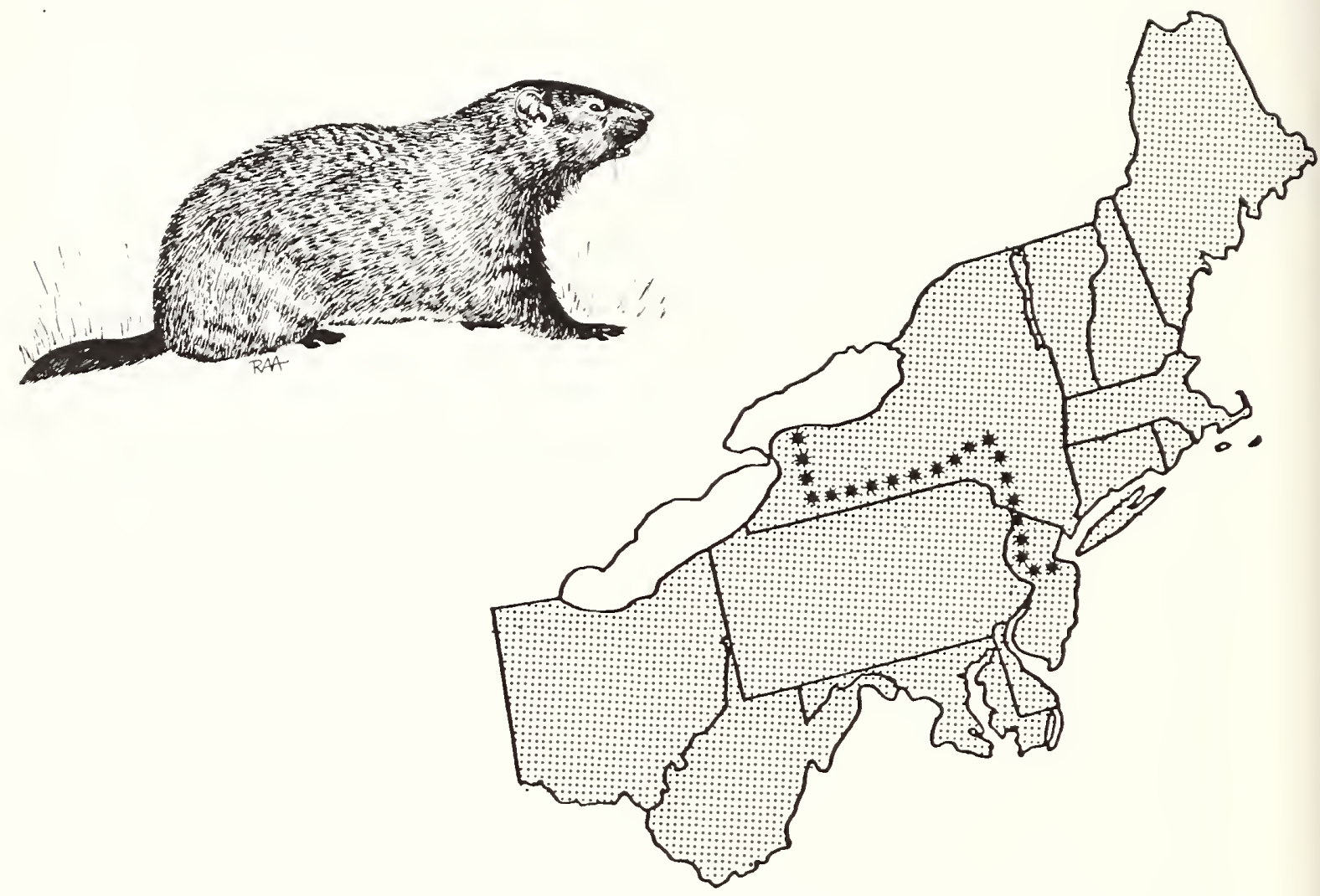

Range: Newfoundland west across the southern Canandian provinces to Alaska south in the eastern United States to Arkansas and Alabama.

Relative abundance in the Northeast: Common

Habitat in the Northeast: Edges of woodlands (seldom in interior), open cultivated land, pastures, meadows, open brushy hillsides.

Special habitat requirements: Open land

\section{Reproduction}

Age at sexual maturity: 1 year, but commonly breeds during second year

Breeding period: Early March to mid-April

Gestation period: 31 to 32 days

Young born: Early April to mid-May

Litter size: 2 to 6 , average 4

No. litters/year: 1

Home range: 0.25 to $0.50 \mathrm{mile}(0.4$ to $0.8 \mathrm{~km}$ ) in diameter (Burt 1957).

In alfalfa and clover the home range boundaries are often within 20 yards (18.2 m) of den (Godin 1977:89). 
Food habits: Succulent green vegetation such as alfalfa, clover, grasses and herbs. Occasionally eats small amounts of insects. Diurnal feeder.

Economic status: Game

Comments: Fossorial except when feeding. Digs extensive system of burrows including a hibernation and nest chamber. Sometimes has separate summer and winter dens.

Key natural history references: Grizzel1 1955, Snyder and Christian 1960, Fa11 1971. 


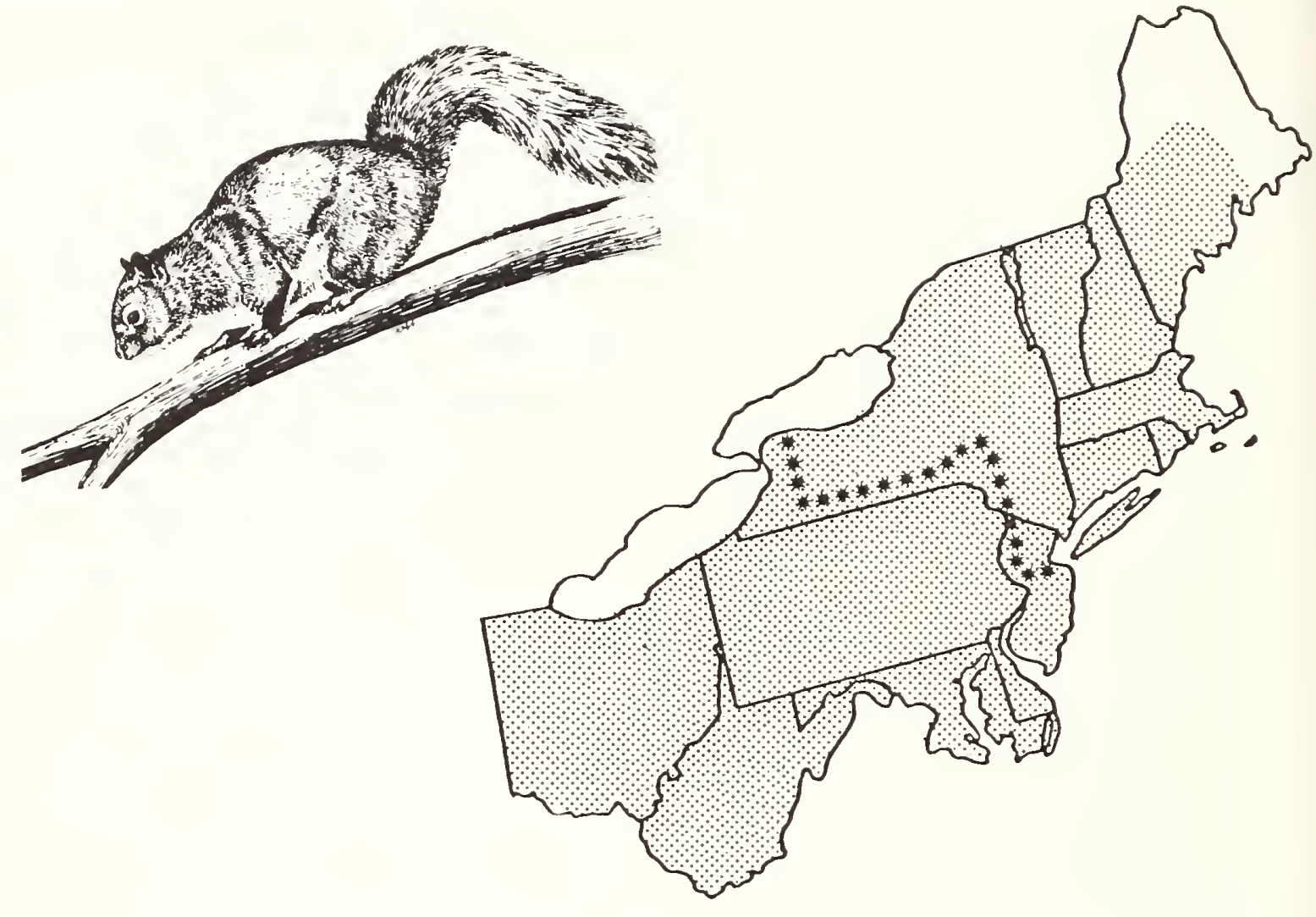

Range: Southern Quebec to Manitoba south to Texas and Florida.

Relative abundance in the Northeast: Common to abundant

Habitat in the Northeast: Deciduous and mixed forests, especially those with trees that produce mast. River bottomland, woodlots in towns, city parks.

Special habitat requirements: Tall trees for dens or leaf nests [nests are usually 25 feet $(7.6 \mathrm{~m})$ or more above ground].

Reproduction

Age at sexual maturity: About 3 months (Smith and Barkalow 1967) to 1 year (Allen 1954)

Breeding period: January to February, occasionally May and June (second litter)

Gestation period: 44 days

Young born: March to Apri1, August

Litter size: 3 to 5 , typically 2 or 3

No. 1itters/year: 1 or 2 
Home range: 2 to 7 acres (0.8 to 2.8 ha) (Burt and Grossenheider 1976:118). The average minimum home range of 43 individuals in mature oakhickory woods in West Virginia was 1.24 acres ( 0.50 ha) (Pack et a 1 1967). 1.20 acres $(0.49 \mathrm{ha})$ was the average range of 55 squirrels in mature to over-mature oak-hickory stand in West Virginia (Doebel and McGinnes 1974). 1.40 acres (0.57 ha) in mature oak-hickory, beech and poplar woodlots in Maryland (Flyger 1960).

Food habits: Diurnal feeder. Consumes nuts, buds, seeds and grains, fungi, fruits, birds' eggs, inner bark of trees. Commonly caches food for their use. Will eat insects and then pupae in spring and summer when preferred foods are scarce (Harvey Smith, pers. comm.).

Economic status: Game

Comments: Arboreal, seldom wandering far from trees. In autumn squirrels often move home ranges short distances to areas with greater food supplies (Sharp 1960) and may occasionally migrate in large numbers over many miles (Larson 1962).

Key natural history references: Uhlig 1955, Pack et al 1967, Godin 1977. 


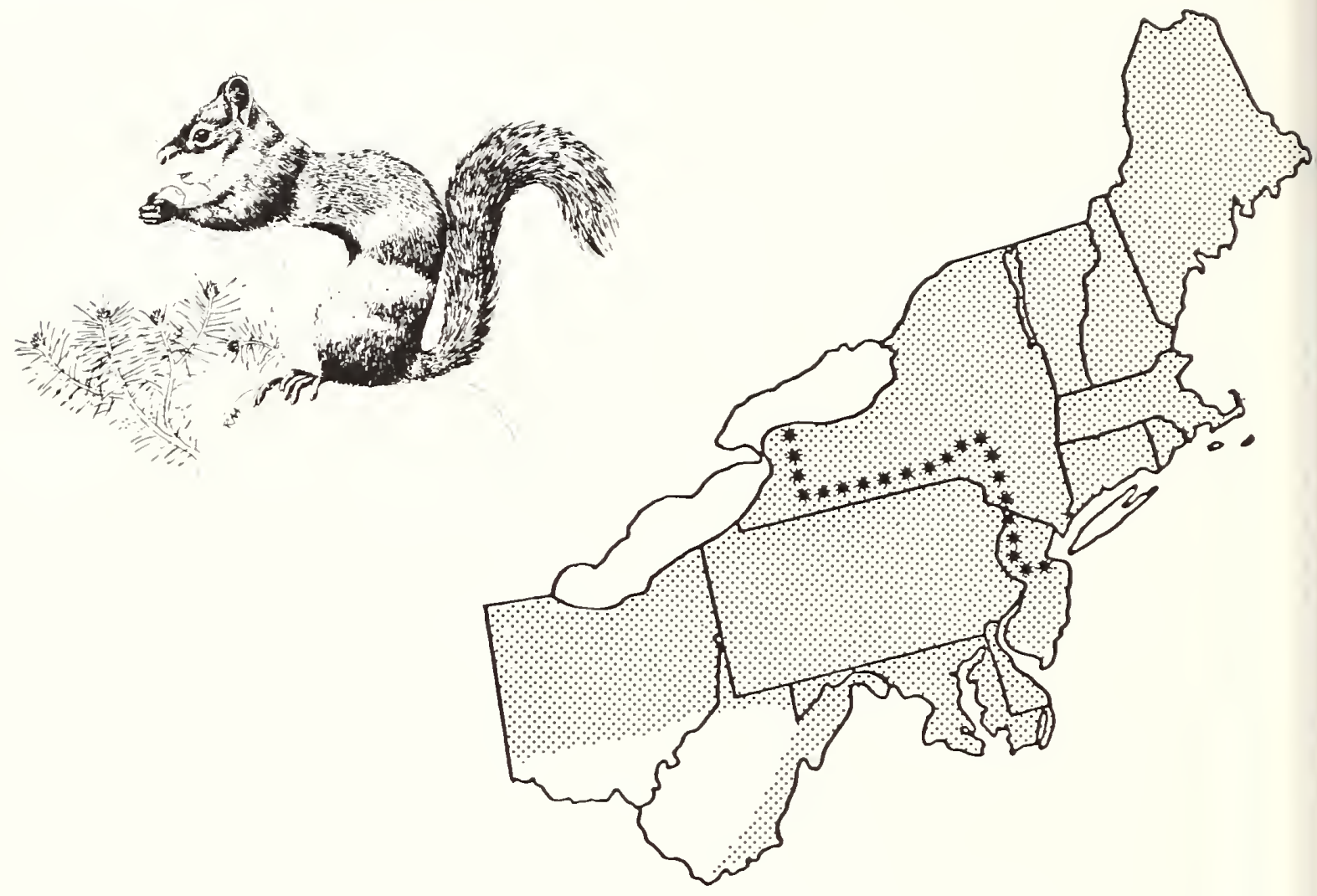

Range: Quebec west to Alaska south in the Appalachians to Tennessee and in the Rockies to New Mexico

Relative abundance in the Northeast: Common to uncommon

Habitat in the Northeast: Coniferous, mixed and occasionally deciduous forests, rural woodlots.

Special habitat requirements: Woodlands with mature trees, conifers preferred.

Reproduction

Age at sexual maturity: 1 year

Breeding period: January to September. Peak: Mid-February to March and June to July

Gestation period: 36 to 40 days

Young born: March to May, August to September

Litter size: 1 to 7 , typically 4 or 5

No. 1itters/year: 1 or 2

Home range: About 1 acre $(0.4 \mathrm{ha})$ when food is plentiful (Hamilton 1939b).

2.73 to 6.03 acres (1.1 to 2.4 ha) (Banfield 1974:139). Less than 200 yards $(182 \mathrm{~m}$ ) in diameter (Burt and Grossenheider 1976:121). Defends feeding and den sites. 
Food habits: Diurnal and crepuscular. Feeds on seeds of conifer cones, nuts, buds, sap, tender leaves, fruits, flowers, fungi, insects, birds' eggs and the young of small vertebrates. Caches food for winter use.

Economic status: Non-game

Comments: Prefers to nest in natural cavity or abandoned woodpecker hole. When unavailable, squirrels may construct globular leaf nests near top of tree or next to trunk or use ground burrows. They become inactive for short periods in winter to escape cold and storms.

Key natural history references: Klugh 1927, Hatt 1929, Hamilton 1939b, Layne 1954. 


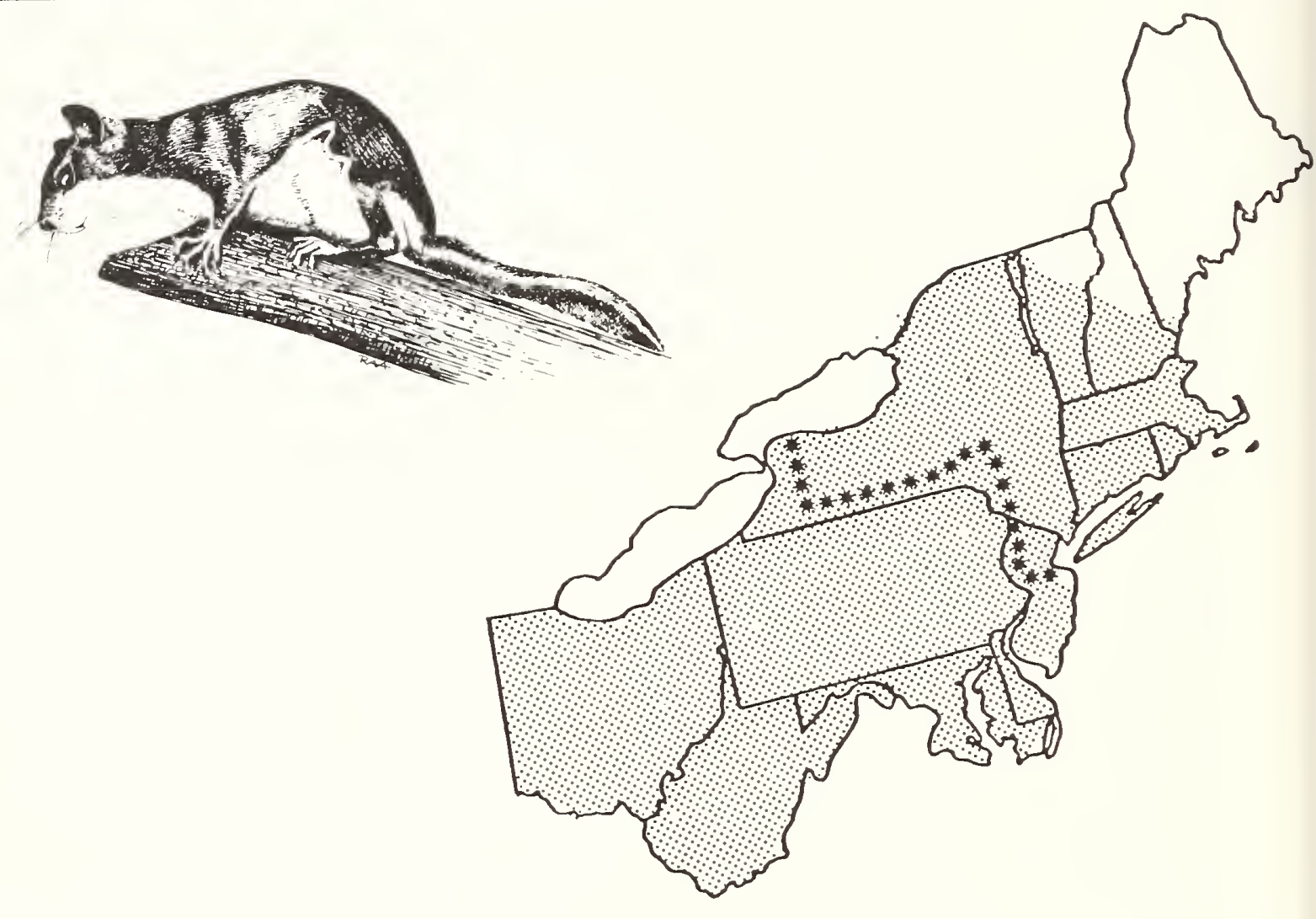

Range: Eastern North America from Nova Scotia west to the Great Lakes and south to East Texas and southern Florida.

Relative abundance in the Northeast: Common to uncommon

Habitat in the Northeast: Mature deciduous and mixed forests especially beech-maple, oak-hickory and poplar.

Special habitat requirements: Several nest sites per individual (Muul 1968), mature woodland with cavity bearing trees. Favors cavities with entrance diameters of 1.6 to 2 inches ( 40 to $50 \mathrm{~mm}$ ) (Dolan and Carter 1977).

Reproduction

Age at sexual maturity: About 6 months

Breeding period: Late February to early March; June to July Gestation period: About 40 days

Young born: April and May; July and August. Peaks: Aprit and August (Massachusetts)

Litter size: 2 to 6 , average 3 to 4

No. litters/year: 2 
Home range: Average 0.41 acre $(0.17 \mathrm{ha})$ for females (may defend entire home range) and 0.53 acre (0.21 ha) for males (no defense) in oak-maple habitat in New York (Madden 1974).

Sample density: Densities of up to 5 individuals/acre (12/ha) have been reported in woodland in New York (Sollberger 1943).

Food habits: Hickory and other nuts, acorns, seeds and fleshy fruits. A7so takes insects and occasionally birds' eggs and fledglings. Most carnivorous of the squirrels. Stores food in den for winter use.

Economic status: Non-game

Comments: Nocturnal feeders; highly sociable--several squirrels may occupy same den at once, especially in winter. Favors abandoned woodpecker holes for den sites. Active throughout the year except during extreme winter cold.

Key natural history references: Burt 1940, Sol1berger 1940 and 1943, Jordan 1948, Muu1 1968. 


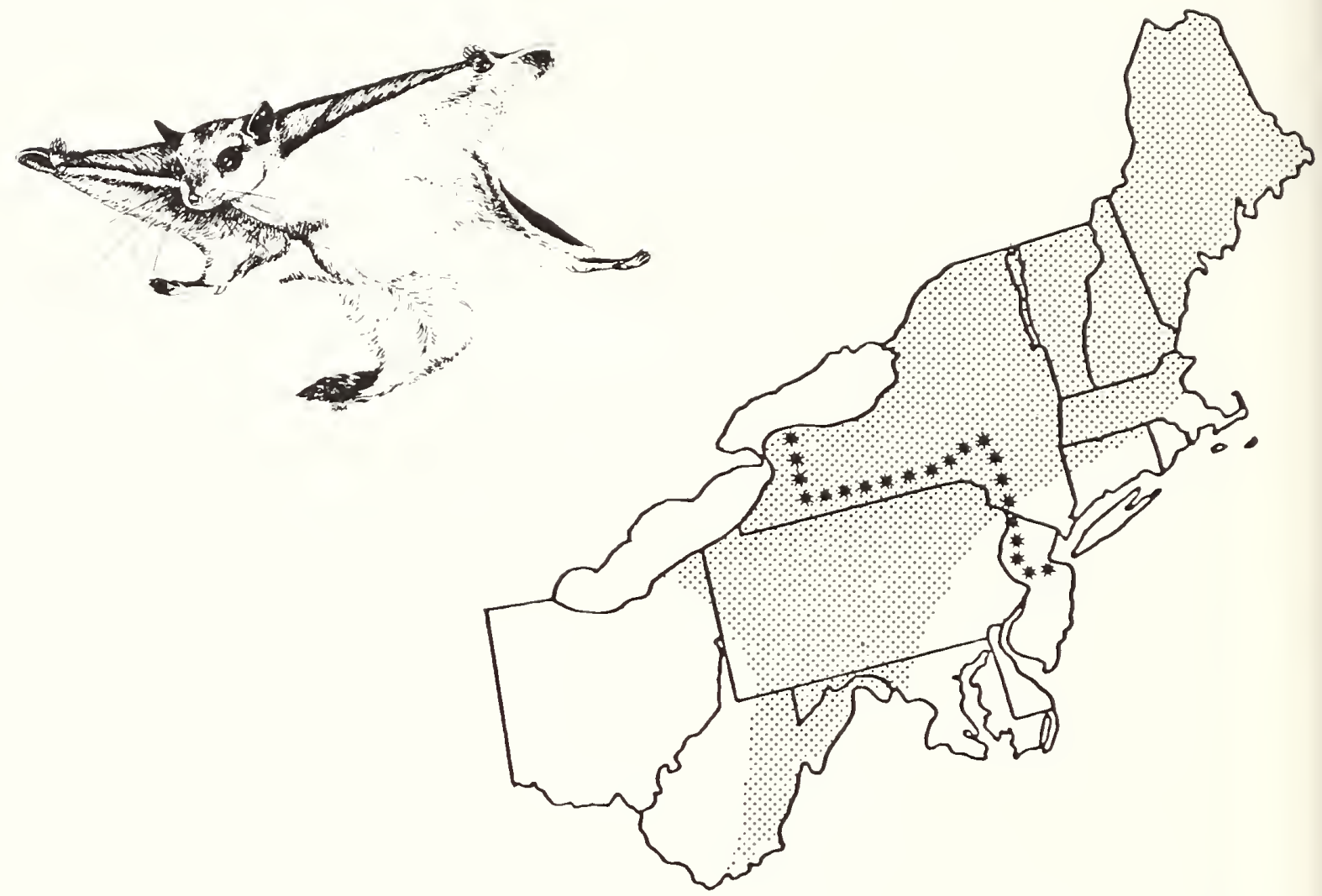

Range: Canada west to Alaska, south in the eastern United States to southern New England, and in the Appalachians to North Carolina. To the west the range extends south to North Dakota, Utah (Rocky Mountains) and northern California.

Relative abundance in the Northeast: Common to uncommon

Habitat in the Northeast: Forests of mixed mature conifers and deciduous trees; less often in purely hardwood forests. Favors cool, heavily wooded areas above 1000 feet $(305 \mathrm{~m})$ elevations.

Special habitat requirements: Mature trees, cavities for winter dens. Arboreal lichens for winter food.

Reproduction

Age at sexual maturity: Probably 6 months to 1 year

Breeding period: February to May and July

Gestation period: About 37 days

Young born: Late March to early July; late August or early September (Godin 1977:103)

Litter size: 2 to 6 , typically 4 or 5

No. litters/year: 1 or 2

Home range: Unknown 
Food habits: Nocturnal feeder. Eats a variety of nuts, especially acorns; also takes seeds, catkins, fruits, buds, insects, mushrooms, birds' eggs and nestlings. Caches food in tree cavities.

Economic status: Non-game

Comments: Summer nest may be constructed on a 1 imb next to tree trunk (usually a conifer). Winter nest is in a cavity, often an old woodpecker hole. Active throughout year except during extreme winter cold. Often highly social in winter dens.

Key natural history references: Cowan 1936, Banfield 1974, Godin 1977. 


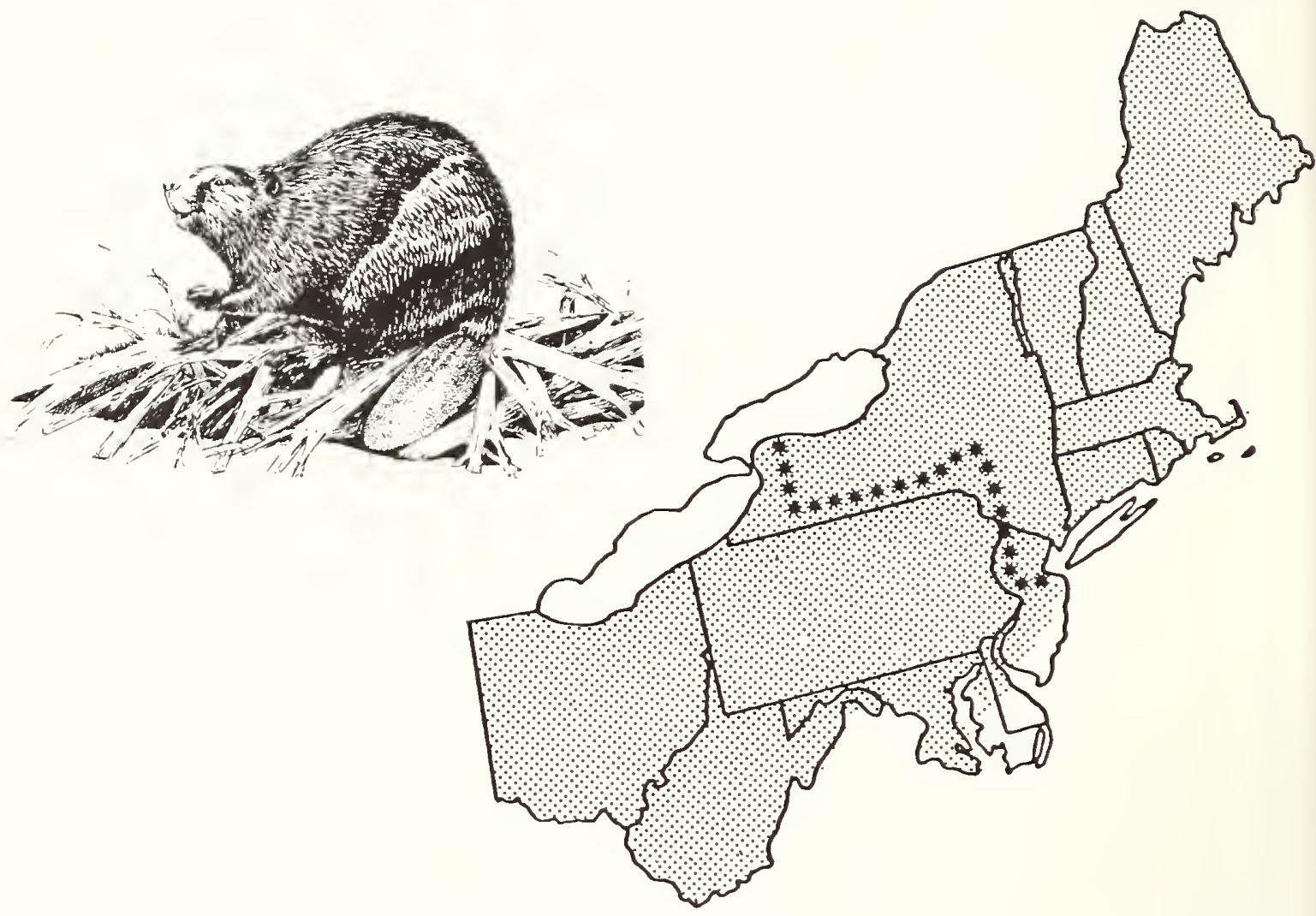

Range: Most of North America with the exception of the high arctic, parts of the southwestern United States, Florida and Mexico.

Relative abundance in the Northeast: Common

Habitat in the Northeast: Small to large slowly flowing brooks, streams or rivers that are usualiy, but not necessarily, bordered by woodland.

Special habitat requirements: Wetlands that provide an adequate food supply and sufficient water depths.

Reproduction

Age at sexual maturity: 1-1/2 to 2 years (Larson 1967)

Breeding period: Mid-January to mid-March

Peak: Mid-February

Gestation period: About 106 days

Young born: Mid-May to early June

Litter size: 1 to 9, typically 3 to 5 . Litter size may be related to type and amount of available food

No. 1itters/year: 1 (Huey 1956).

Home range: Beavers have been known to range in excess of 450 feet

$(137 \mathrm{~m})$ from water in search of food (Hiner 1938) but generality remain much closer to lodge. 
Food habits: Mainly a nocturnal feeder. Consumes bark of deciduous trees especially aspen, balsam poplar, alder, willow, birch and maple. Also takes herbaceous vegetation especially aquatics, and some grasses. Stores food under ice for winter use.

Economic status: Furbearer

Comments: Monogamous pair bond is life-long. Constructs dams to retain water and large lodge of mud and sticks to enclose den for raising of young and winter shelter or digs burrows in banks.

Key natural history references: Hodgdon and Larson 1973, Godin 1977, Jenkins and Busher 1979.

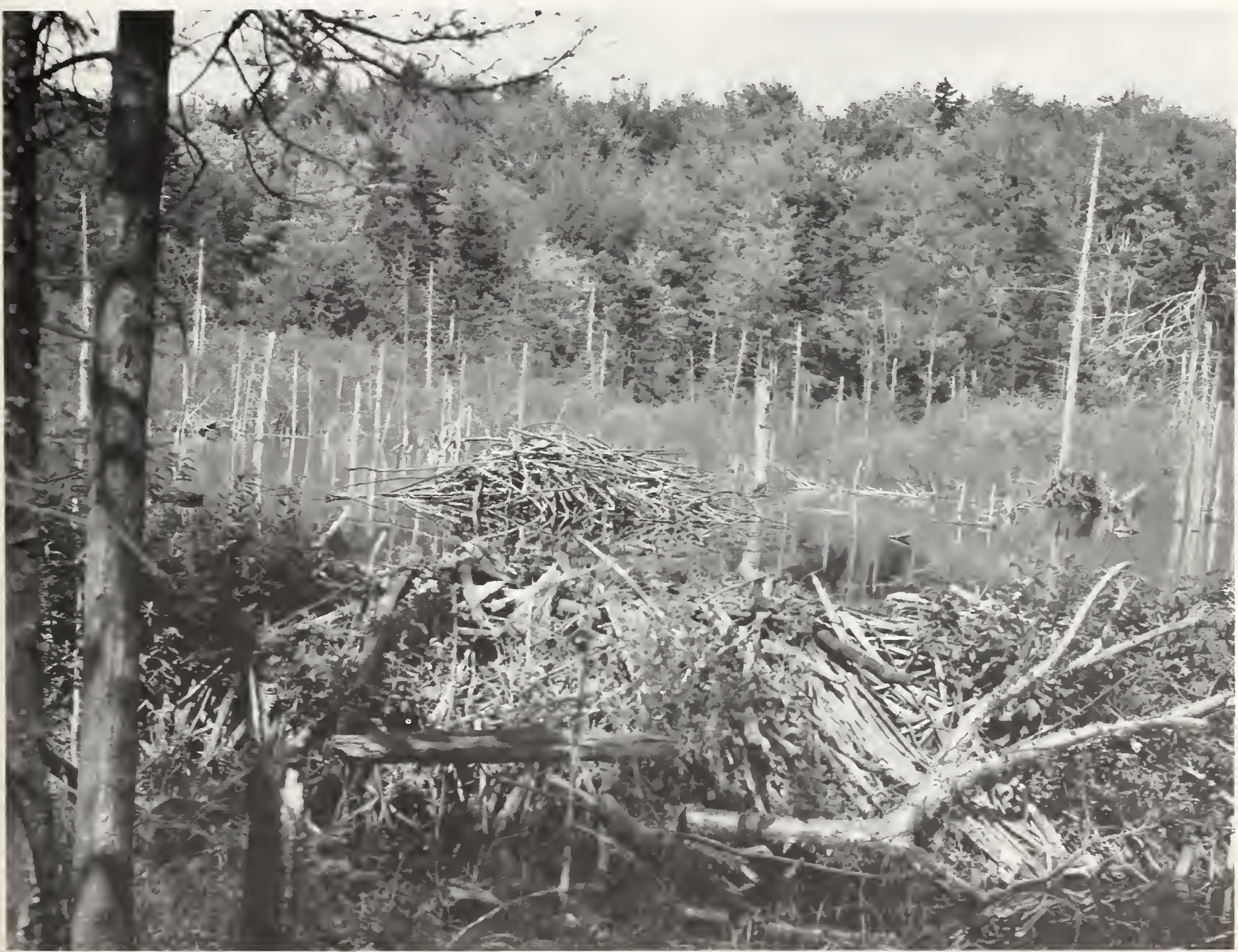



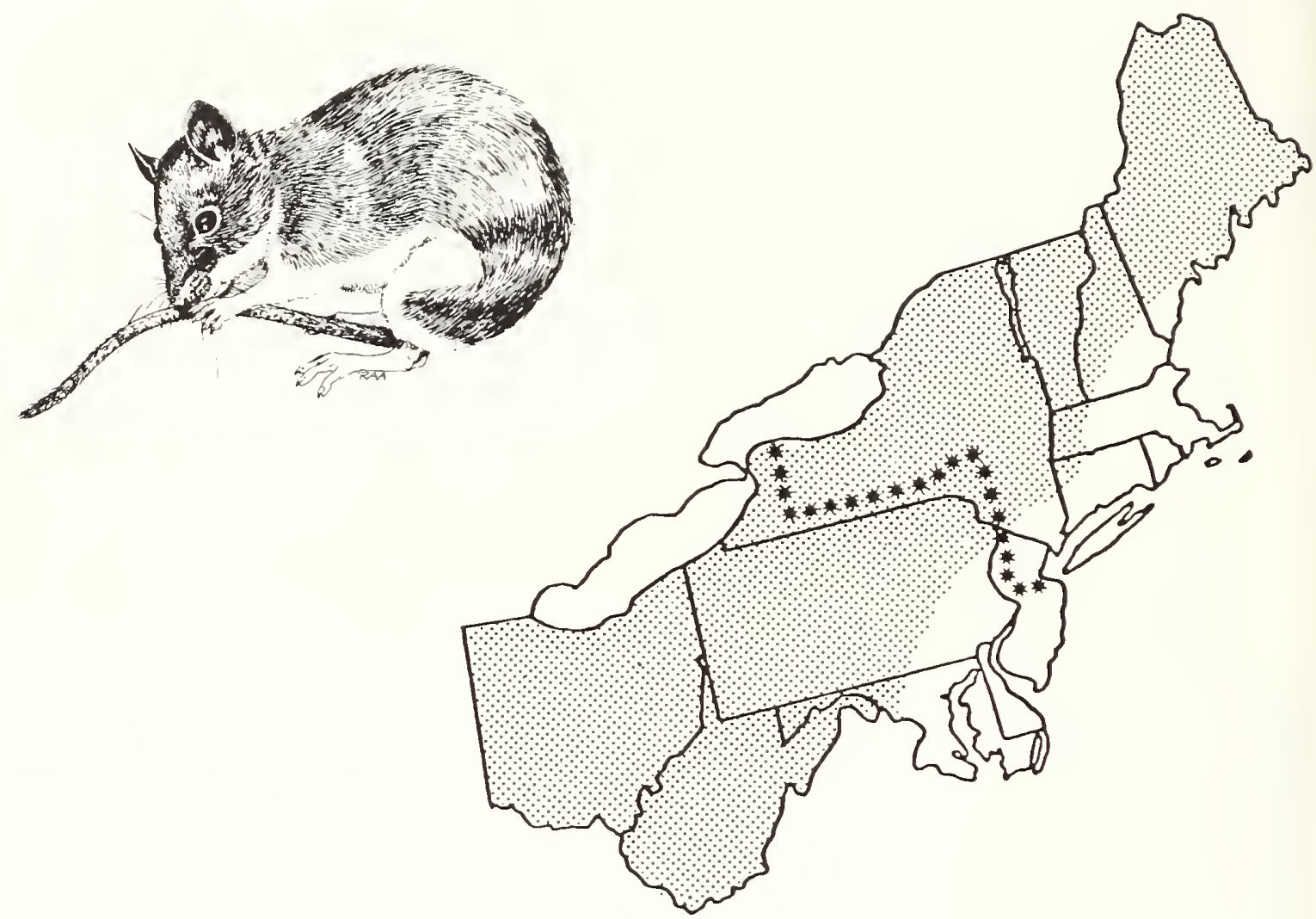

Range: Most of North America except northern Canada, western Mexico, the southeastern United States and the Atlantic coastal plain.

Relative abundance in the Northeast: Common

Habitat in the Northeast: Mainly occurs in interiors or along edges of coniferous or mixed forests, along field borders, stone walls, in out-buildings near areas with small trees and dense ground cover (Godin 1977:111). Uses recent forest clearcuts (Kirkland 1977b).

Reproduction

Age at sexual maturity: Females: 40 to 50 days

Breeding period: March through October

Males: about 60 days

Gestation period: About 23 days

Young born: April to October

Litter size: 3 to 7 , average 4

No. litters/year: 3 or 4 
Home range: Average 2.3 acres $(0.9 \mathrm{ha})$ for adult males and 1.4 acres (0.6 ha) for adult females in virgin hardwood forest in Michigan (Blair 1942). 0.10 to 0.31 acre $(0.04$ to $0.13 \mathrm{ha}$ ) for adult males and 0.12 to 0.25 acre $(0.05$ to $0.10 \mathrm{ha})$ for adult females (Manville 1949).

Sample density: Density normally varies from a low of one mouse/ 2 acres ( $1 / 0.8 \mathrm{ha})$ in spring to a high of $22 \mathrm{mice} / 2$ acres (22/0.8 ha) in autumn (Banfield 1974:165).

Food habits: Nuts, seeds, grains, fruits, mushrooms. A1so eats sma 11 invertebrates such as worms, snails, insect larvae and occasionally carrion. Caches food in fall for winter use.

Economic status: Non-game

Comments: Nocturnal. Active throughout the year except during severe cold spells or winter storms. Nests in a variety of places including stone walls, buildings, old burrows of smal1 mammals, under logs or in tree cavities.

Key natural history references: Blair 1942, K1ein 1960, King 1968, Choate 1973, Godin 1977. 


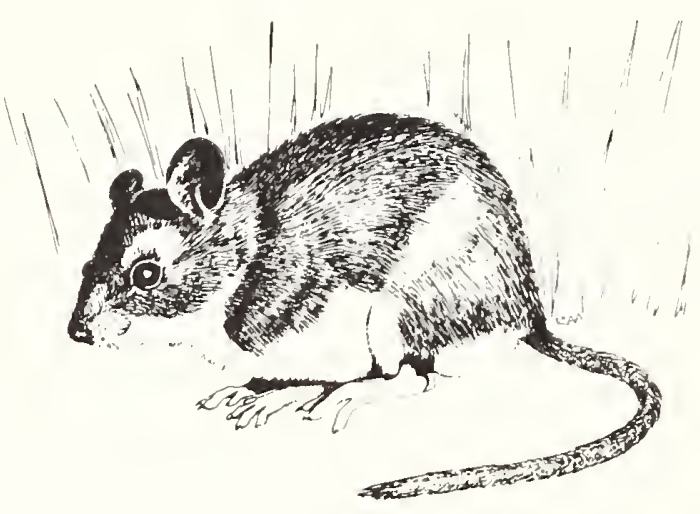


Food habits: Seeds, acorns, nuts, fruits, tender green plants, insects and small amounts of meat (carrion). Commonly stores food for future use.

Economic status: Non-game

Comments: Nests in a variety of places including stone walls, tree cavities, under stumps or logs or in buildings. Nocturnal and active in all seasons.

Key natural history references: Svihla 1932, Burt 1940, Snyder 1956, King 1968. 
Eastern woodrat

Rodentia

Neotoma floridana

Myomorpha

Cricetidae

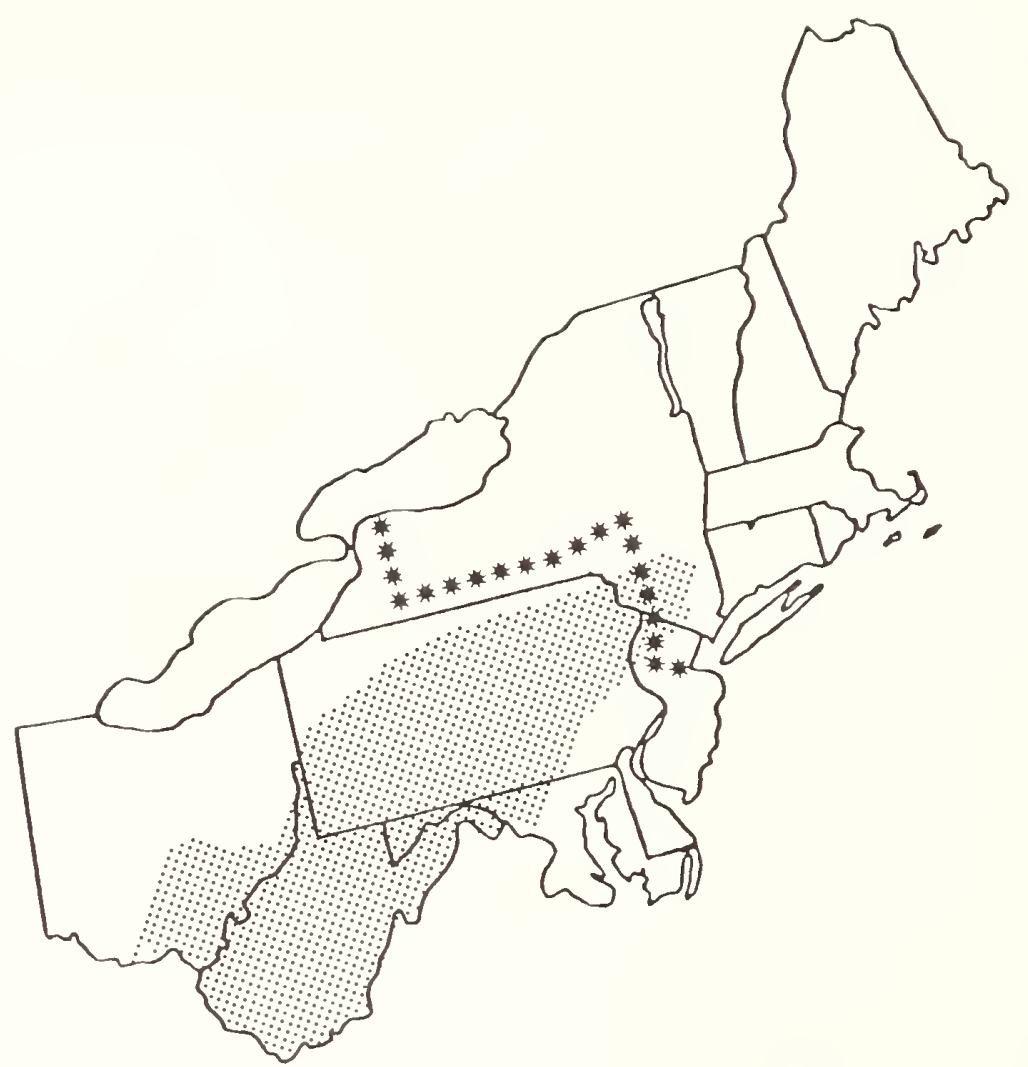

Range: Southeastern New York south through the Appalachians and Ohio River Valley to the Gulf Coast, west to East Texas. Also occurs in Colorado and southwestern South Dakota. Absent from much of Virginia and North Carolina, the southern tip of Florida, the north central states and the far West.

Relative abundance in the Northeast: Uncommon to rare

Habitat in the Northeast: Rocky cliffs, caves, outcrops, talus slopes or bare rocky inclines. Rarely uses abandoned buildings.

Special habitat requirements: Extensive rocky areas with boulders and crevices.

Reproduction

Age at sexual maturity: 1 year, possibly earlier (Poole 1940)

Breeding period: Spring to autumn

Gestation period: Probably 30 to 36 days (Poole 1940), 30 to 39 days (Pearson 1952)

Young born: Mid-March to September

Litter size: 1 to 3

No. litters/year: 2 or 3 
Home range: Seldom greater than 100 yards $(91 \mathrm{~m}$ ) in diameter (Burt and Grossenheider 1976:168). One individual was tracked in snow for a distance of 200 yards $(183 \mathrm{~m})$ in the Blue Ridge Mountains (Poole 1940). Goertz (1970) found that males had larger ranges ( 0.64 acre, 0.26 ha) than females $(0.41$ acre, $0.17 \mathrm{ha}$ ) in Oklahoma.

Food habits: Seeds, nuts, fruits, twigs, leaves, fungi. May cache food for winter use (Goodwin 1935:125).

Economic status: Non-game

Comments: Builds nest of sticks, plant fibers, leaves and debris in a rocky crevice among ledges or in cave or less commonly in abandoned building. Nocturnal. Active throughout the year.

Key natural history references: Goodwin 1935, Poole 1940, Pearson 1952, Rainey 1956, Goertz 1970. 

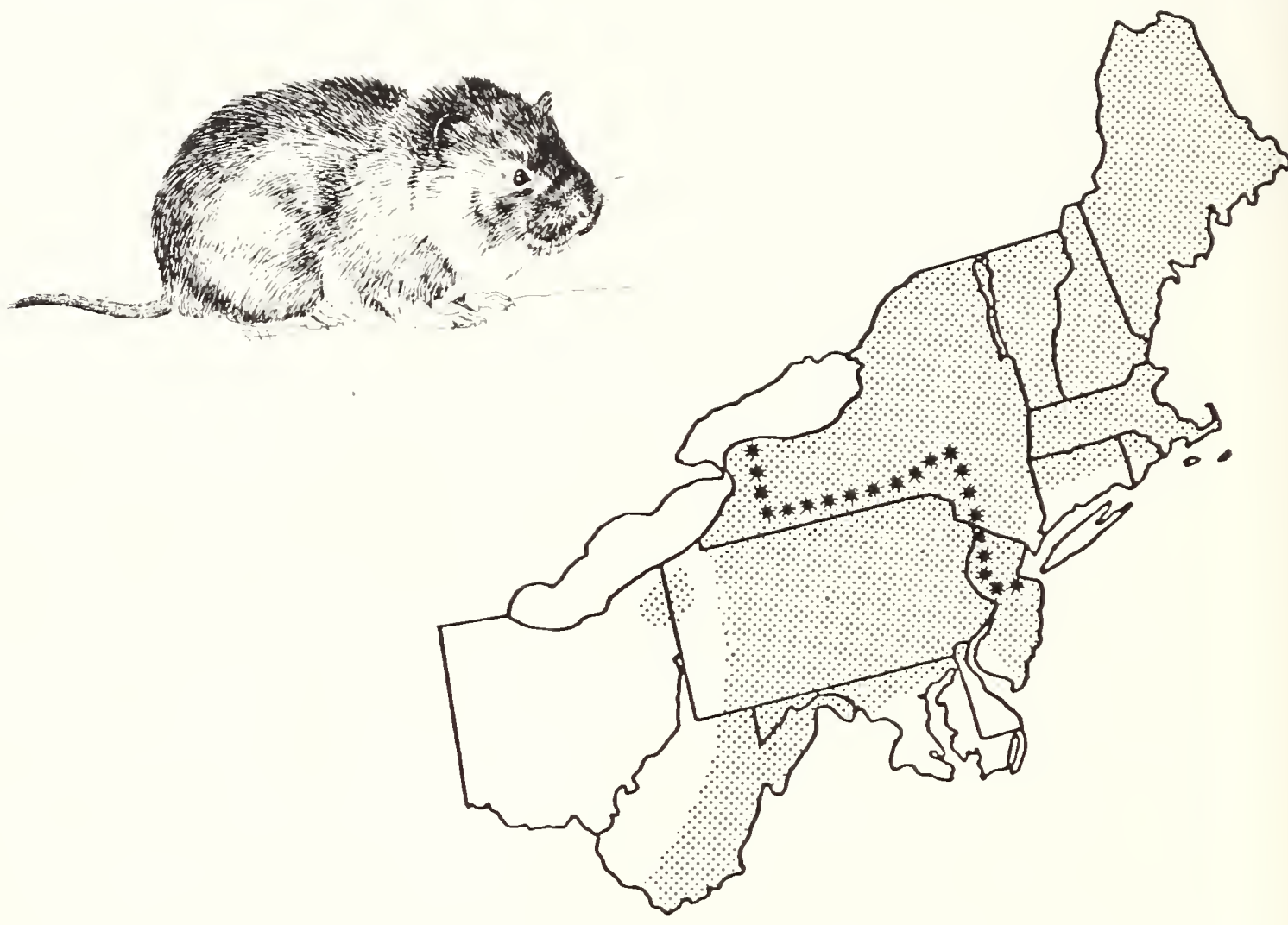

Range: Canadian Provinces south in the United States in the Appalachians to northern Georgia and in the Rockies to southwestern New Mexico. Also occurs in the northern border states.

Relative abundance in the Northeast: Common

Habitat in the Northeast: Cool moist deciduous, mixed or coniferous

forests among mossy rocks, logs, tree roots or other cover. Less commonly found near stone walls at woodland edges or near talus slopes. Favors damp situations in coniferous or mixed woods. Highest densities found in sub-climax communities (Cameron 1958:46). Uses young clearcuts in deciduous and coniferous woodlands (Kirkland 1978) and mixed forest (Lovejoy 1975).

Special habitat requirements: Water sources such as springs, brooks or bogs, debris cover (fallen trees, stumps, rocks, slash).

Reproduction

Age at sexual maturity: Possibly 3 or 4 months (B1air 1941:683).

Breeding period: Mid-January to late November

Peak: February to October

Gestation period: 17 to 19 days

Young born: February to December Litter size: 1 to 8 , typically 4 to 6

No. 1itters/year: Probably 2 or more 
Home range: About 0.25 acre (0.10 ha) (Burt and Grossenheider 1976:182); about 0.57 acre ( 0.23 ha) for one female and 3.56 acres ( 1.44 ha) for one male in virgin hardwood forest in northern Michigan (Blair 1941).

Food habits: Mainly green vegetation but also eats seeds, nuts, fungi, bark, insects and carrion.

Economic status: Non-game

Comments: Mainly nocturnal, active year-long. Commonly uses burrow systems of moles or other mamma 1s. Nests under logs, stumps, roots or snow (winter).

Key natural history references: Svihla 1930, Criddle 1932, Miller and Getz 1972 and 1973. 
Meadow vole

Rodentia

Microtus pennsylvanicus

Myomorpha

Cricetidae

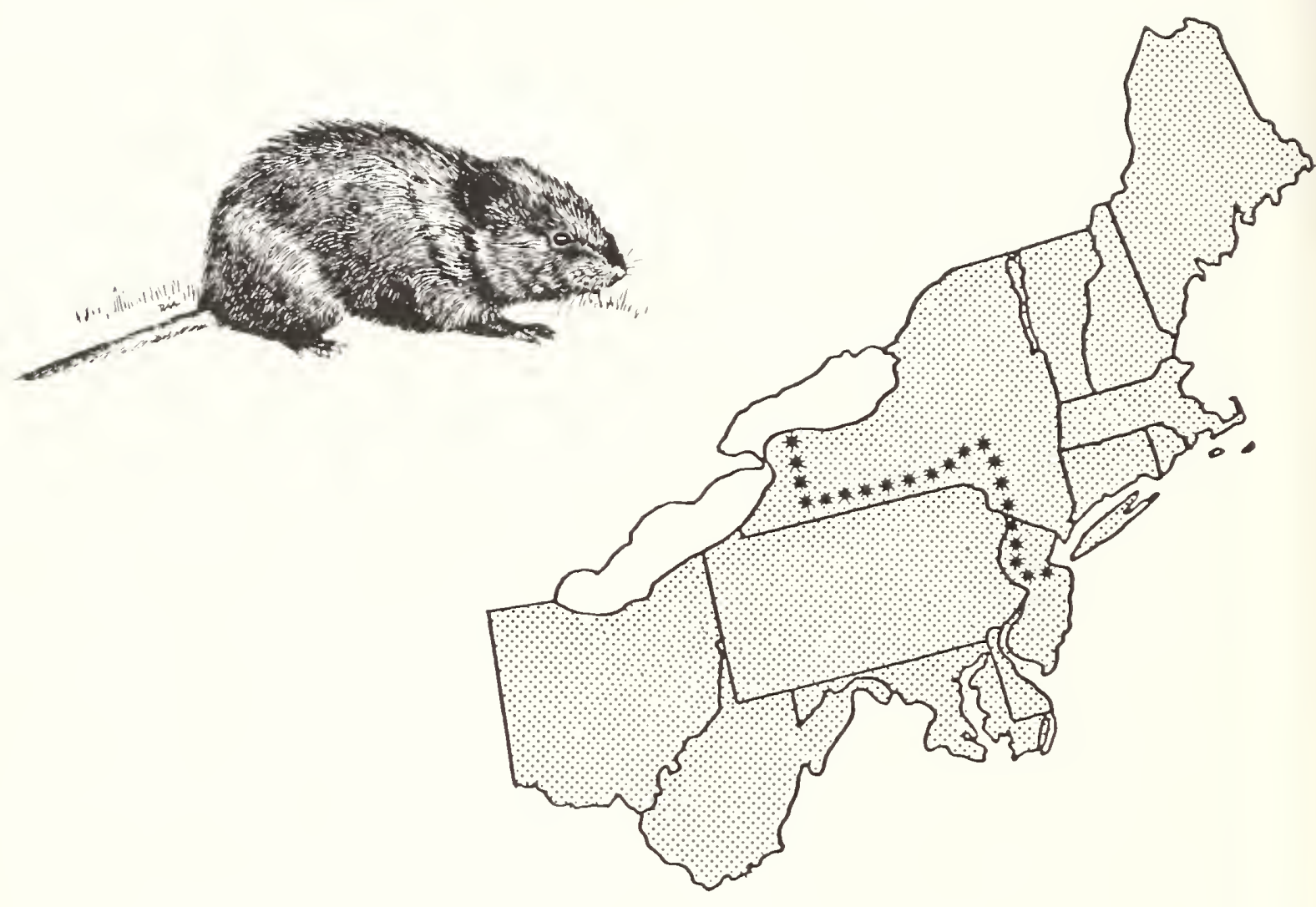

Range: Southern two-thirds of Canada and southern Alaska, south to Washington, northern New Mexico, northern Missouri and northern Georgia.

Relative abundance in the Northeast: Abundant

Habitat in the Northeast: Fields, pastures, orchards, freshwater and salt water marshes and meadows, borders of streams and lakes, open and wooded swamps, bogs; less commonly in open woods and clearcuts.

Special habitat requirements: Herbaceous vegetation, loose organic soils.

Reproduction

Age at sexual maturity: Females: about 25 days

Males: about 45 days.

Breeding period: Throughout the year, if snow provides

insulating cover. Peak: April to October

Gestation period: About 21 days

Young born: Throughout the year

Litter size: 1 to 9 , typically 4 or 5

No. 1itters/year: May produce 5 to 10 . Known to produce 17

(Hamilton 1941) 
Home range: Seldom exceeded 0.06 acre (0.02 ha) in New York in good habitat (Hamilton 1937). Sizes may range from 0.08 to 0.23 acre (0.03 to $0.09 \mathrm{ha})$ (Banfield 1974). Defensive behavior displayed during male encounters may indicate that they defend territories (Gets 1961b).

Food habits: Eats mainly vegetable material especially tender grasses, bulbs, cambium of roots and stems, seeds and grains. occasionally caches food when supply is abundant and takes small amounts of meat when available.

Economic status: Non-game. May damage commercially-grown trees by girdling trunk and roots.

Comments: Active day and night throughout the year. Builds extensive tunnel and runway systems. Nests under boards, rocks, logs and in other sheltered spots including tunnels. There is a cyclic fluxuation in populations of about four years (Hamilton 1937).

Key natural history references: Bailey 1924, Hamilton 1937, Blair 1940b, Get 1961b.

99 


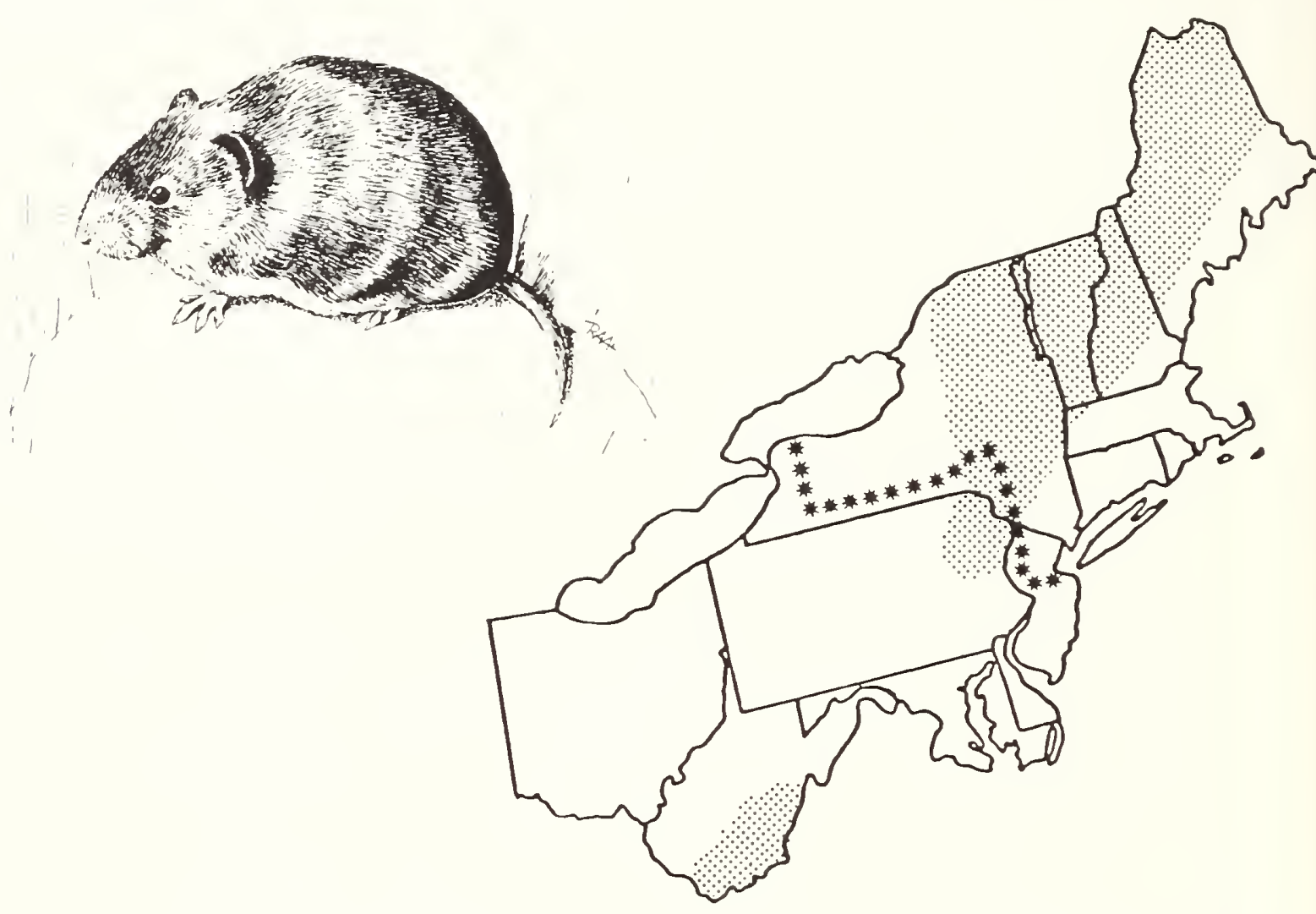

Range: Cape Breton Island and eastern Quebec west to northeastern Minnesota. The mountains of northern New England, south in the Appalachians to North Carolina.

Relative abundance in the Northeast: Unknown, possibly rare, but may be locally common in appropriate habitat.

Habitat in the Northeast: Coniferous and mixed forests at higher elevations. Favors cool, damp, moss-covered rocks and talus slopes in vicinity of streams. Kirkland (1977a) captured rock voles in clearcuts in West Virginia, habitat not previously reported for this species. Timm et al (1977) found voles using edge between boulder field and mature forest in Minnesota. They have been taken at a new low elevation (1509 feet, $460 \mathrm{~m}$ ) in the Adirondacks (Kirkland and Knipe 1979).

Special habitat requirements: Cool, moist, rocky woodlands with herbaceous groundcover and flowing water. 
Reproduction
Age at sexual maturity: Females and males are mature when body length exceeds $140 \mathrm{~mm}$ and $150 \mathrm{~mm}$, respectively, and total body weight exceeds $30 \mathrm{~g}$ for both sexes (Martin 1971). Females born in late spring produce litters in first summer (Timm et al 1977).

Breeding period: Late March to mid-October (Martin 1971) Gestation period: Unknown Young born: Early spring to fal1; peak: June Litter size: 1 to 7 , typically 3 or 4 No. litters/year: Up to 3

Home range: Unknown

Food habits: Bunchberry, wavy-leafed thread moss, blackberry seeds (Martin 1971). May browse on blueberry bushes (twigs and leaves), mushrooms and Clinton's 1ily. A captive subadult ate insects (Timm et al 1977). Appears to be diurnal with greatest feeding activity taking place in morning (Martin 1971). Less active in afternoon in northern Minnesota (Timm et a) 1977).

Economic status: Non-game

Comments: Occurs locally in small colonies throughout its range. Natural history information is lacking for this species. Habitat preferences appear to vary geographically.

Key natural history references: Burt 1957, Martin 1971, Banfield 1974, Kirkland 1977a, Timm et al 1977. 
Pine vole

Rodentia

Myomorpha

Microtus pinetorum

Cricetidae

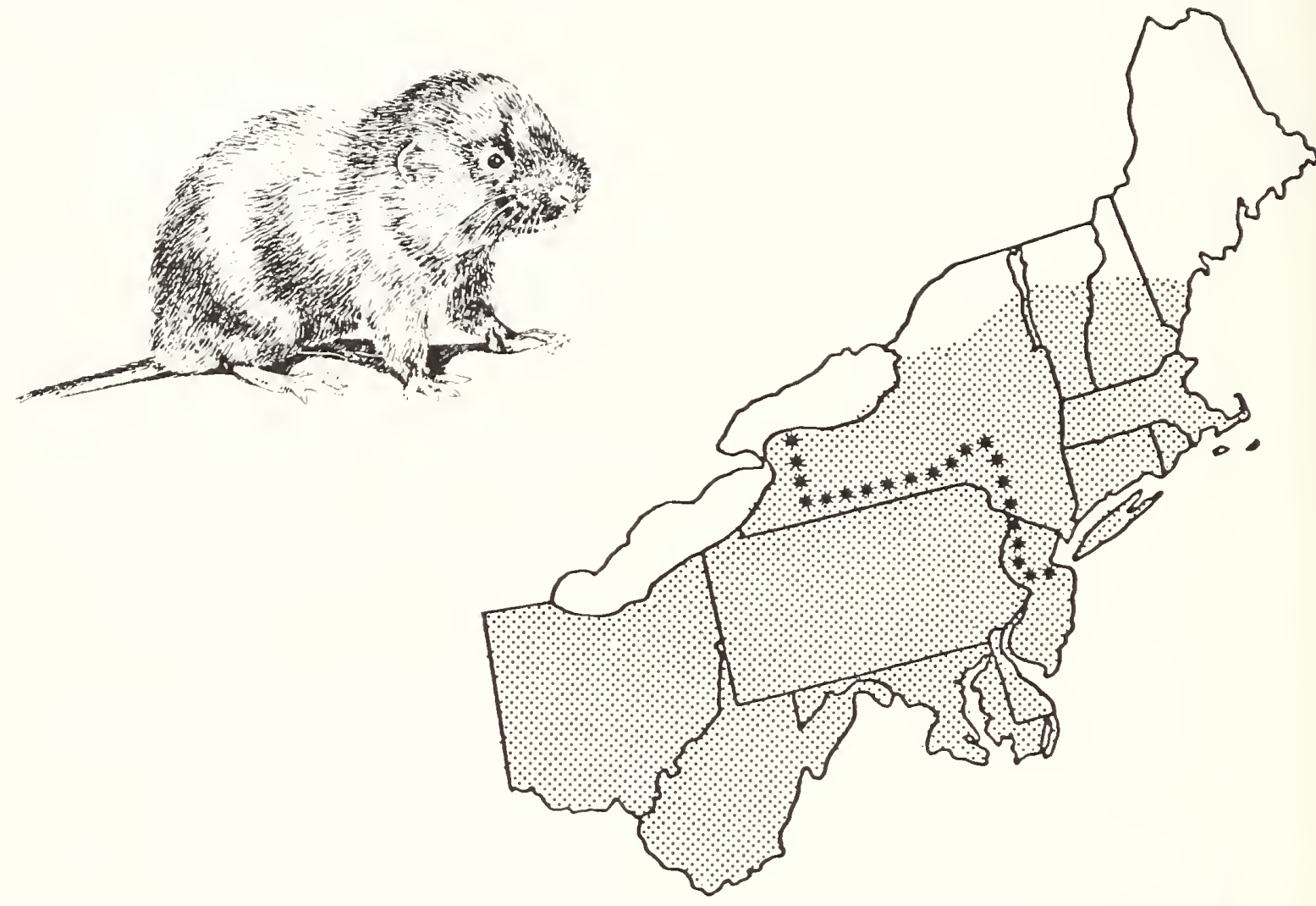

Range: Northcentral New England, west to central Wisconsin south to East Texas and northern Florida.

Relative abundance in the Northeast: Common to uncommon

Habitat in the Northeast: Deciduous forests, grasslands, meadows and orchards. Occurs in marshes and swamps but favors well-drained uplands.

Special habitat requirements: May require groundcover of leaves (duff) or grass; moist we17-drained soils.

Reproduction

Age at sexual maturity: 2 months (Hamilton 1938)

Breeding period: Mid-February to mid-November

Gestation period: About 24 days

Young born: Early March to early December

Litter size: 2 to 4

Home range: About 0.25 acre $(0.10 \mathrm{ha})$ in oak-hickory woods in Michigan (Burt 1940). Home ranges of voles in Connecticut had average maximum diameters of 30.7 yards $(33.7 \mathrm{~m})$ for females and 30 yards $(32.7 \mathrm{~m}$ ) for males (Miller and Getz 1969). 
Sample density: Densities ranged from 0 to 6 individuals/acre

(0 to 14.6/ha) in upland oak woods (Miller and Getz 1969).

Food habits: Subterranean tubers, roots and bulbs; seeds, nuts, fruits, bark and leaves. Often caches large amounts of food in burrows.

Economic status: Non-game. It may be a severe pest species in nurseries and orchards in the Northeast.

Comments: Highly fossorial spending much time digging tunnel systems and foraging below ground. Tunnels may be dug as deep as 12 inches $(30.5 \mathrm{~cm})$ but are general1y 3 or 4 inches ( 7 to $10 \mathrm{~cm}$ ) below ground surface. Nests are built under logs or rocks or in burrows well below ground. Active throughout the year.

Key natural history references: Hamilton 1938, Burt 1940, Benton 1955, Miller and Getz 1969. 


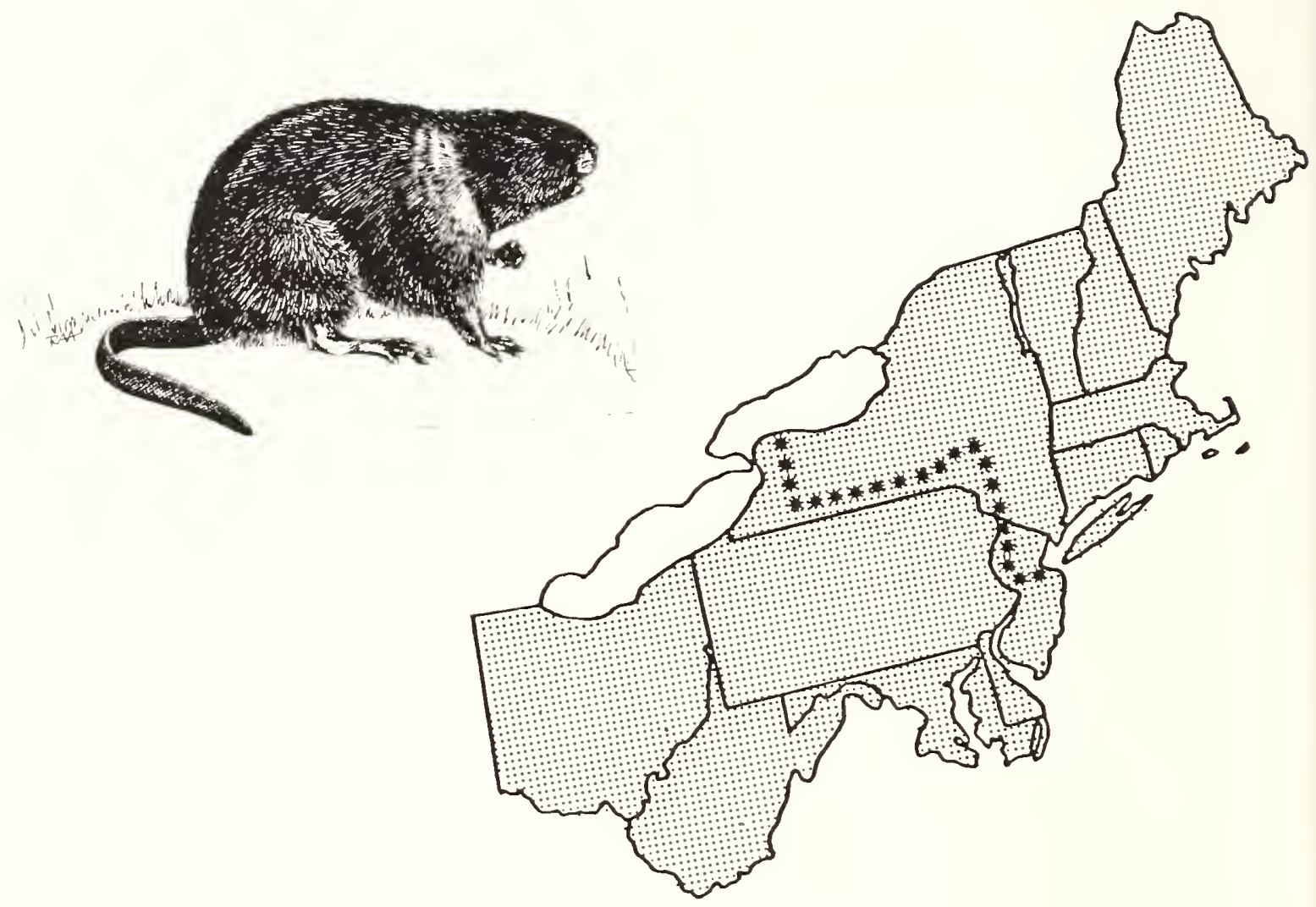

Range: Throughout most of Canada except portions directly east and northwest of Hudson Bay. In most of the United States except parts of California, Texas, South Carolina, Georgia, and all of Florida.

Relative abundance in the Northeast: Common to uncommon

Habitat in the Northeast: Marshes, shallow portions of lakes, ponds, swamps, sluggish streams, drainage ditches. Most abundant in areas with cattails.

Special habitat requirements: Wetlands with dense emergent vegetation and stable water levels.

Reproduction

Age at sexual maturity: Possibly 6 months, and perhaps as early as 4 months (Harvey Smith, pers. comm.)

Breeding period: Late February to August (Harvey Smith, pers. comm.)

Gestation period: 28 or 30 days (Godin 1977:133)

Young born: April or May and June or July; September and early October litters have been observed (Harvey Smith, pers. comm.)

Litter size: 1 to 8 , typically 5 or 6

No. 1itters/year: Average 3 (Harvey Smith, pers. comm.) 
Home range: Usually with in 200 yards $(182 \mathrm{~m}$ ) of den (Errington and Errington 1937). Females with young will defend nest site.

Food habits: A variety of aquatic plants especially cattails, reeds, pondweeds, bulrushes, and water 7 ilies, fresh water clams and other smali aquatic animals. Builds roofed feeding platforms near house.

Economic status: Furbearer

Comments: May construct a dome-shaped chamber of weeds over water [less than 2 feet $(0.6 \mathrm{~m})$ deep] for nest or may dig a den in stream or ditch bank. Mainly nocturnal but often seen in daylight. Active throughout the year. Populations tend to follow a ten-year cycle (Elton and Nicholson 1942).

Key natural history references: Johnson 1925, Shanks and Arthur 1952, Errington 1967 and 1963, Godin 1977. 


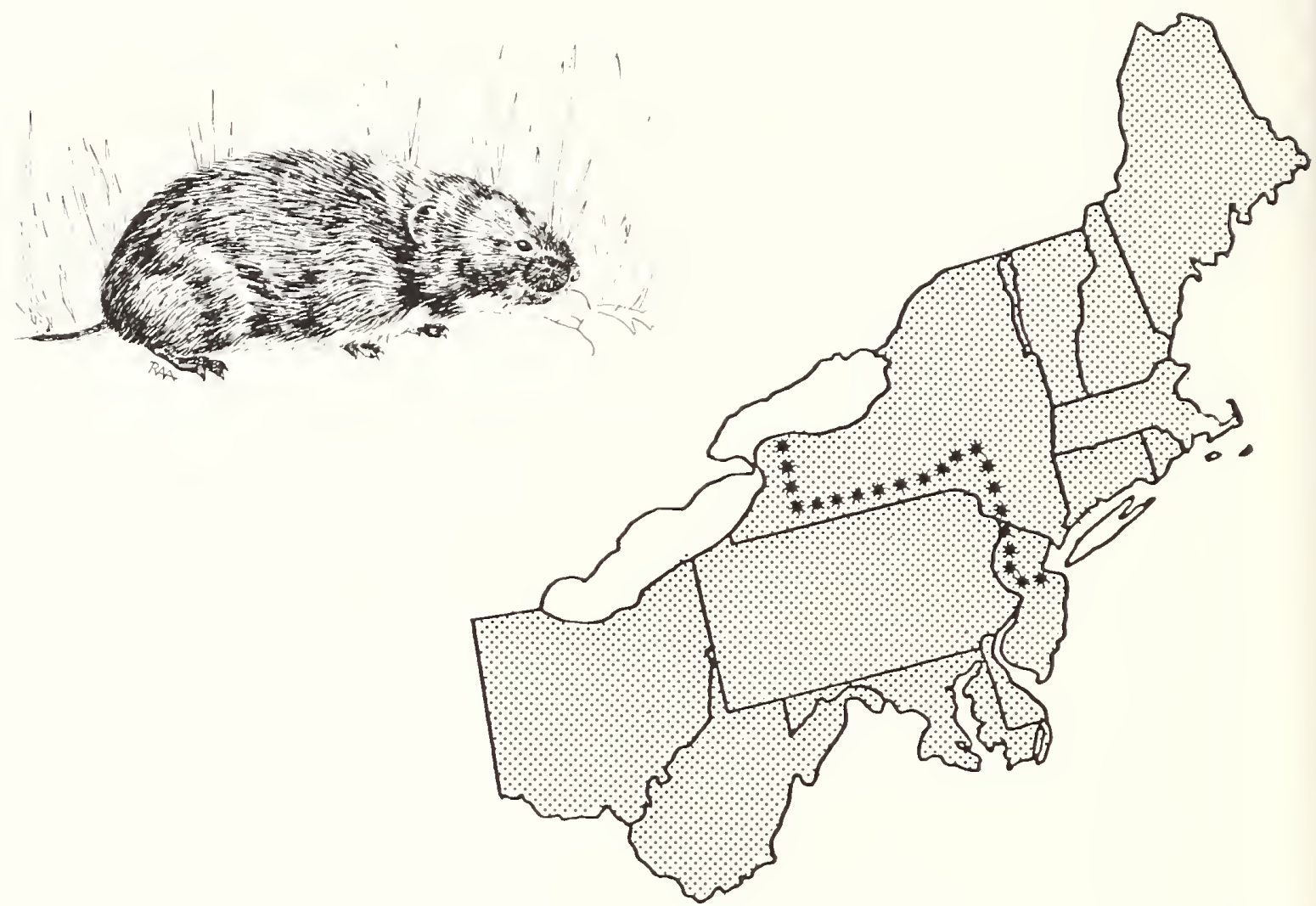

Range: Quebec west to Manitoba, south to Kansas, Arkansas, Virginia and Maryland.

Relative abundance in the Northeast: Uncommon, in very scattered colonies.

Habitat in the Northeast: Uses a variety of habitat from marshes, open meadows and orchards to moist deciduous and mixed forests.

Favors sphagnum bogs and deciduous woodlands with a thick layer of loose duff. Uses clearcuts and other small forest openings with adequate groundcover (McKeever 1952, Kirkland 1977b).

Special habitat requirements: Moist soils.

\section{Reproduction}

Age at sexual maturity: Unknown

Breeding period: Throughout the year. Peak: April to September.

Gestation period: 21 to 23 days

Young born: Throughout the year; most young are born between

May and September. In New Jersey, females

produced a litter every 67 days (average) in spring and summer (Conner 1959).

Litter size: 1 to 8 , typically 2 to 5 
Home range: 1 acre $(0.40 \mathrm{ha})$ for 1 individual in sphagnum bog with tamarack and black spruce forming a dense canopy (Buckner 1957). 0.20 to 0.50 acre (0.08 to $0.20 \mathrm{ha}$ ) (Banfield 1974:188). Females defend nest.

Food habits: Tender parts of herbaceous plants, especially leaves, stems and seeds of grasses and sedges, fruits. Occasionally takes fungi, bark and insects.

Economic status: Non-game

Comments: Tunnel systems are deep, 6 to 12 inches $(15$ to $30 \mathrm{~cm}$ ) below ground and complex with many side chambers for resting, feeding and storing of food. Surface runways serve as travel lanes. Winter nest may be located in burrow, summer nest may be on surface in tuft of grass. Active during the day and night at al1 seasons of the year. Life history is poorly known.

Key natural history references: Buckner 1957, Conner 1959, Godin 1977. 
Northern bog lemming

Rodentia

Myomorpha

Synaptomys borealis

Cricetidae

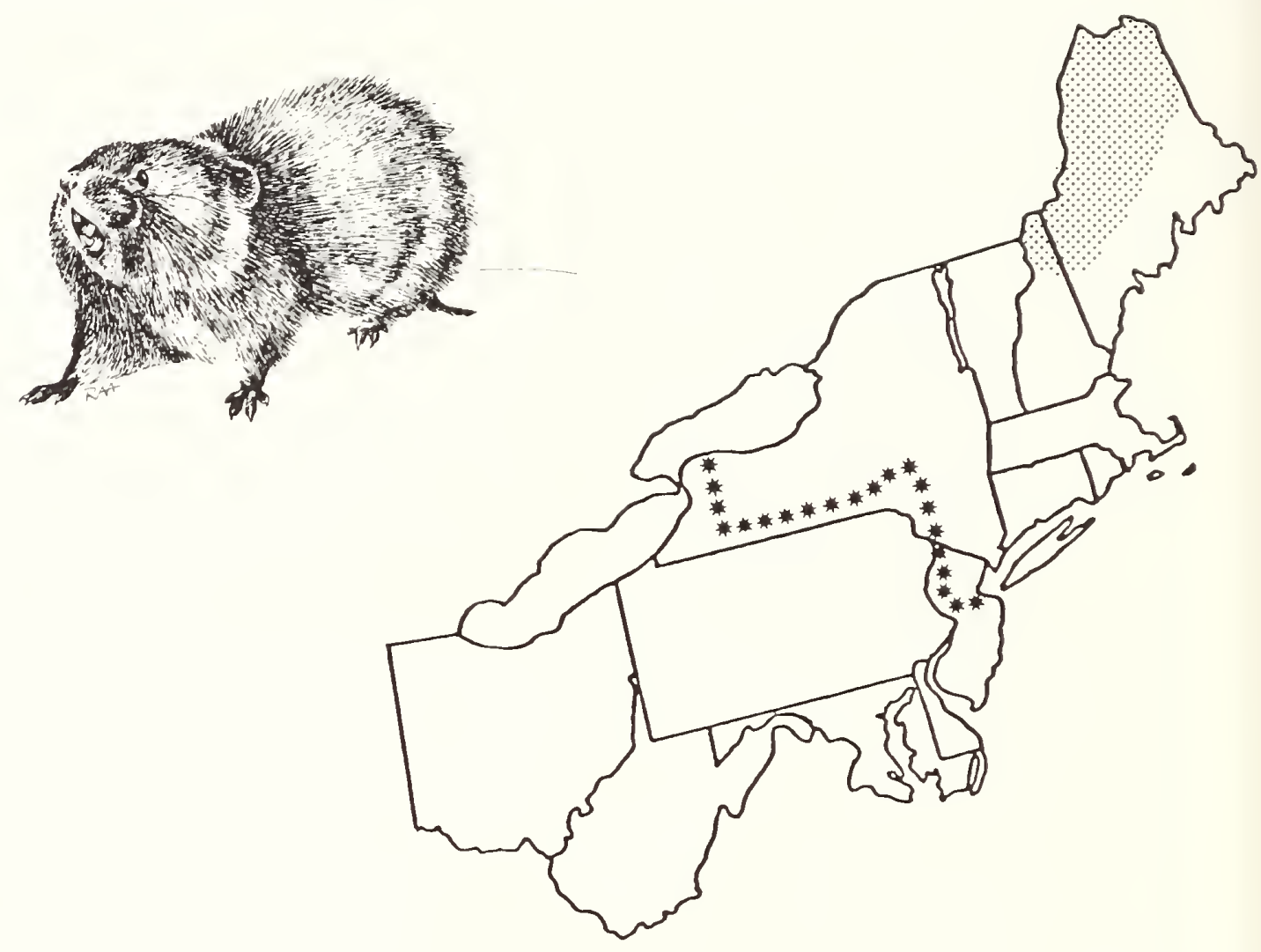

Range: Labrador west to central Alaska, south to Washington, southeastern Manitoba and northern New England.

Relative abundance in the Northeast: Rare and local

Habitat in the Northeast: Sphagnum bogs, damp weedy meadows, mossy spruce woods, hemlock and beech forests.

Special habitat requirements: Moist to wet, loose soils or leaf mold.

Reproduction

Age at sexual maturity: Unknown

Breeding period: Unknown

Gestation period: Unknown

Young born: May to August

Litter size: 4 to 8 , typically 4

Home range: Unknown

Food habits: Succulent parts of grasses and sedges, seeds, fungi.

Economic status: Non-game

Comments: Uses both deep burrows several inches below ground and shallow runways on surface. This species life history is poorly known.

Key natural history references: Banfield 1974, Godin 1977. 

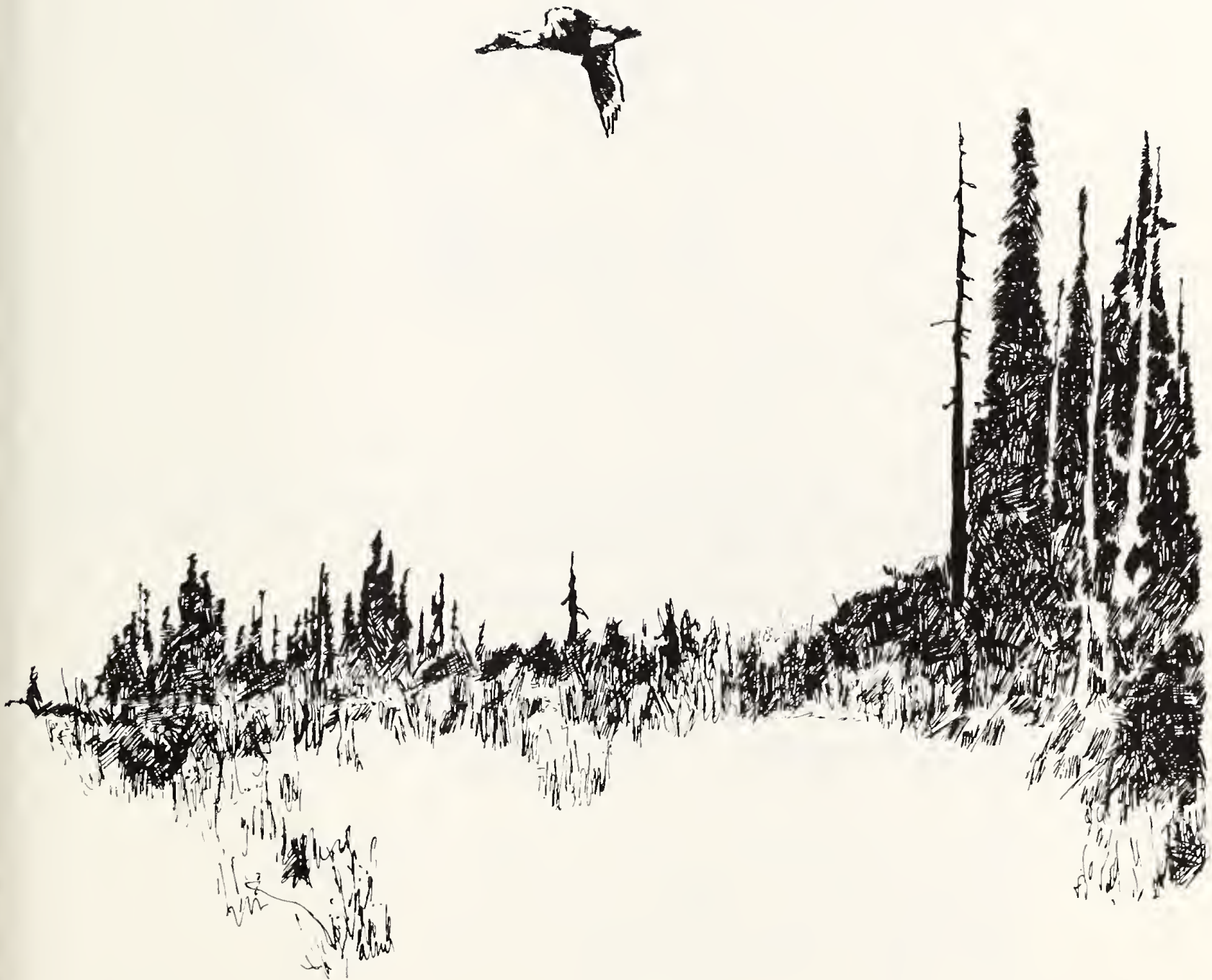
Black rat

Rodentia

Myomorpha

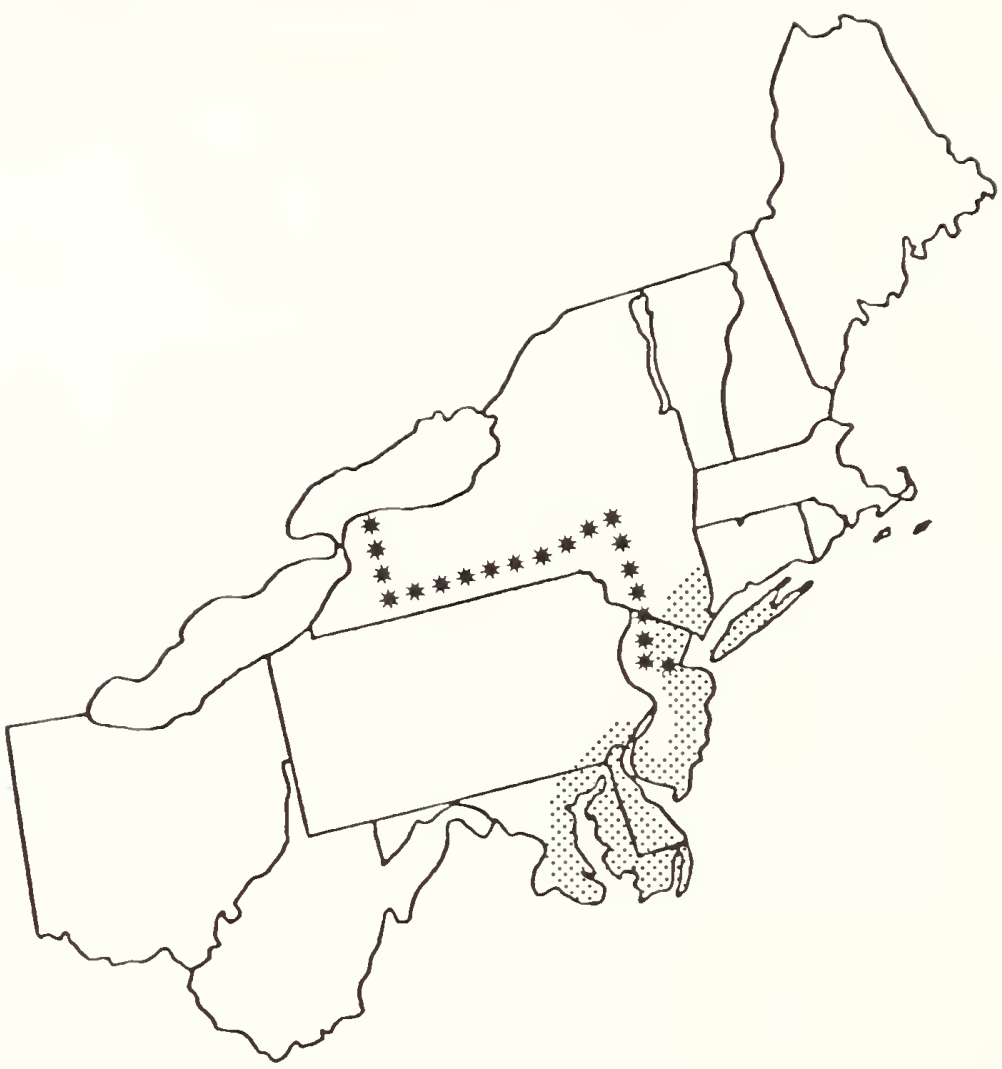

Range: Formerly in New England, may now inhabit southern coastal sections of the northeastern United States. Occurs mainly in seaport towns and cities in southeastern and northwestern U.S.

Relative abundance in the Northeast: Uncommon

Habitat in the Northeast: Spaces in walls and under floors of houses, barns, warehouses and other buildings. Favors areas that are wel1 above ground; rarely in burrows, cellars or sewers.

Special habitat requirements: Largest populations are associated with man-made structures, especially buildings.

Reproduction

Age at sexual maturity: Probably about 3 months

Breeding period: Probably throughout the year

Gestation period: About 21 days

Young born: Probably throughout the year

Litter size: 6 to 22, average 9

Food habits: Seeds, nuts, insects, fruits, garbage, carrion.

Economic status: Non-game. Destructive to stored food supplies and buildings. Transmits diseases. 
Comments: The Norway rat has probably replaced the black rat in New England. Where black rat and Norway rat ranges overlap, the black rat generally occupies the upper floors of buildings. Mainly nocturnal, active throughout the year.

Key natural history references: Banfield 1974, Godin 1977. 


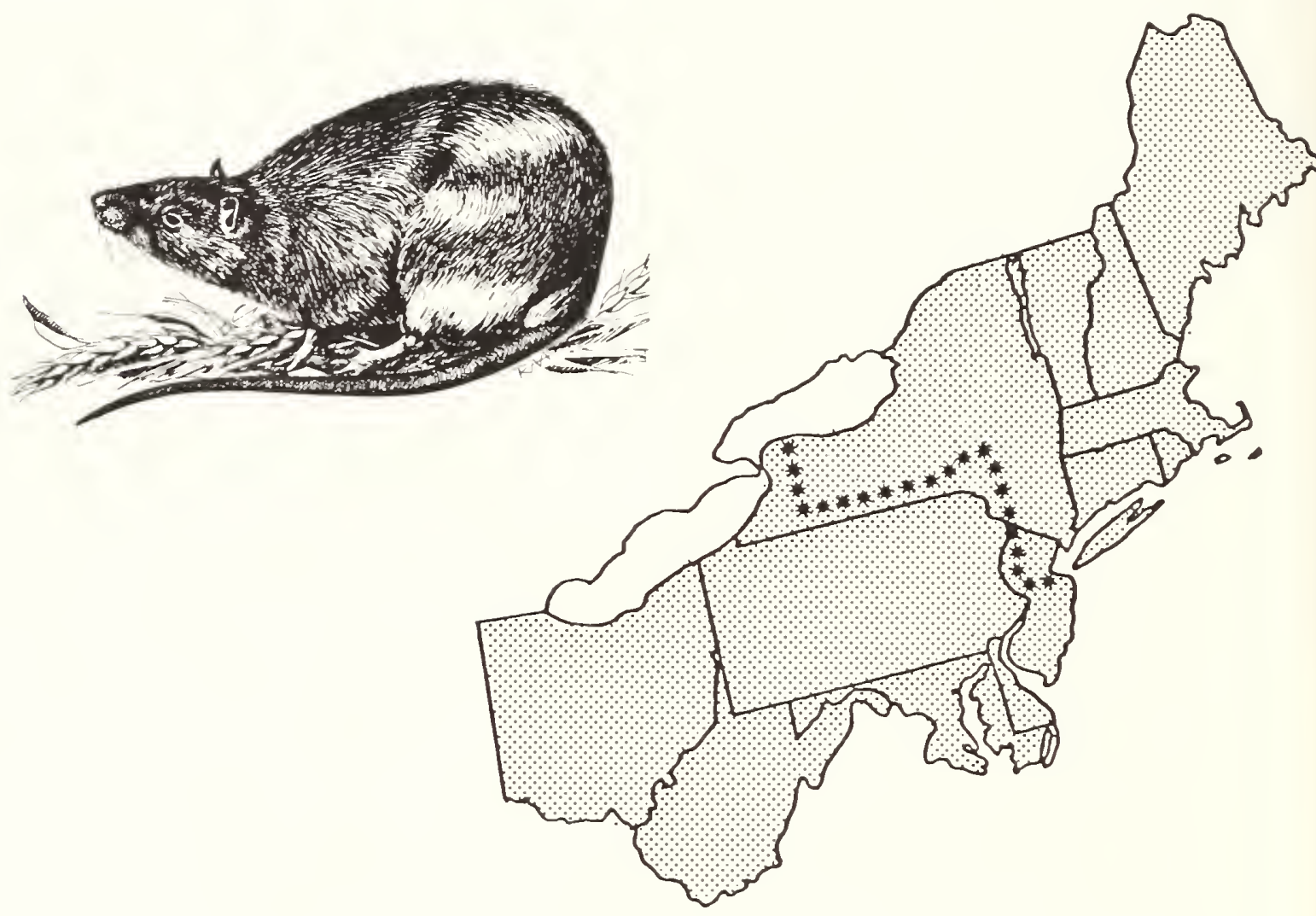

Range: Throughout most of North America with numbers varying with climate and habitat.

Relative abundance in the Northeast: Abundant

Habitat in the Northeast: Concentrates in areas where food is abundant such as waterfronts, farms, cities and dumps. They may also inhabit rural and suburban residences.

Special habitat requirements: Buildings, dumps or loose soil for digging burrows near food suppiy.

Reproduction

Age at sexual maturity: 80 to 85 days

Breeding period: Throughout the year

Peaks: Spring and Autumn

Gestation period: 21 to 22 days

Young born: In a 17 seasons of year

Litter size: 2 to 14 , average 9

No. Titters/year: 3 to 12 , average 6

Home range: About 25 to 50 yards (23 to $46 \mathrm{~m}$ ) in diameter (Banfield

1974:222). Movements were confined to an area 100 to 150 feet (30 to $46 \mathrm{~m}$ ) in diameter both in residential and farm areas (Davis 1953). 
Food habits: Omnivorous, taking fruits, vegetables, grains, carrion and fresh meats, garbage.

Economic status: Non-game. Probably the most economically important of the rodents because of the damage they cause to buildings and the diseases they spread to humans.

Comments: Colonial and closely associated with man. Active mainly at night throughout the year. May dig extensive burrow systems for nesting and escaping predators.

Key natural history references: Davis 1953, Calhoun 1962. 


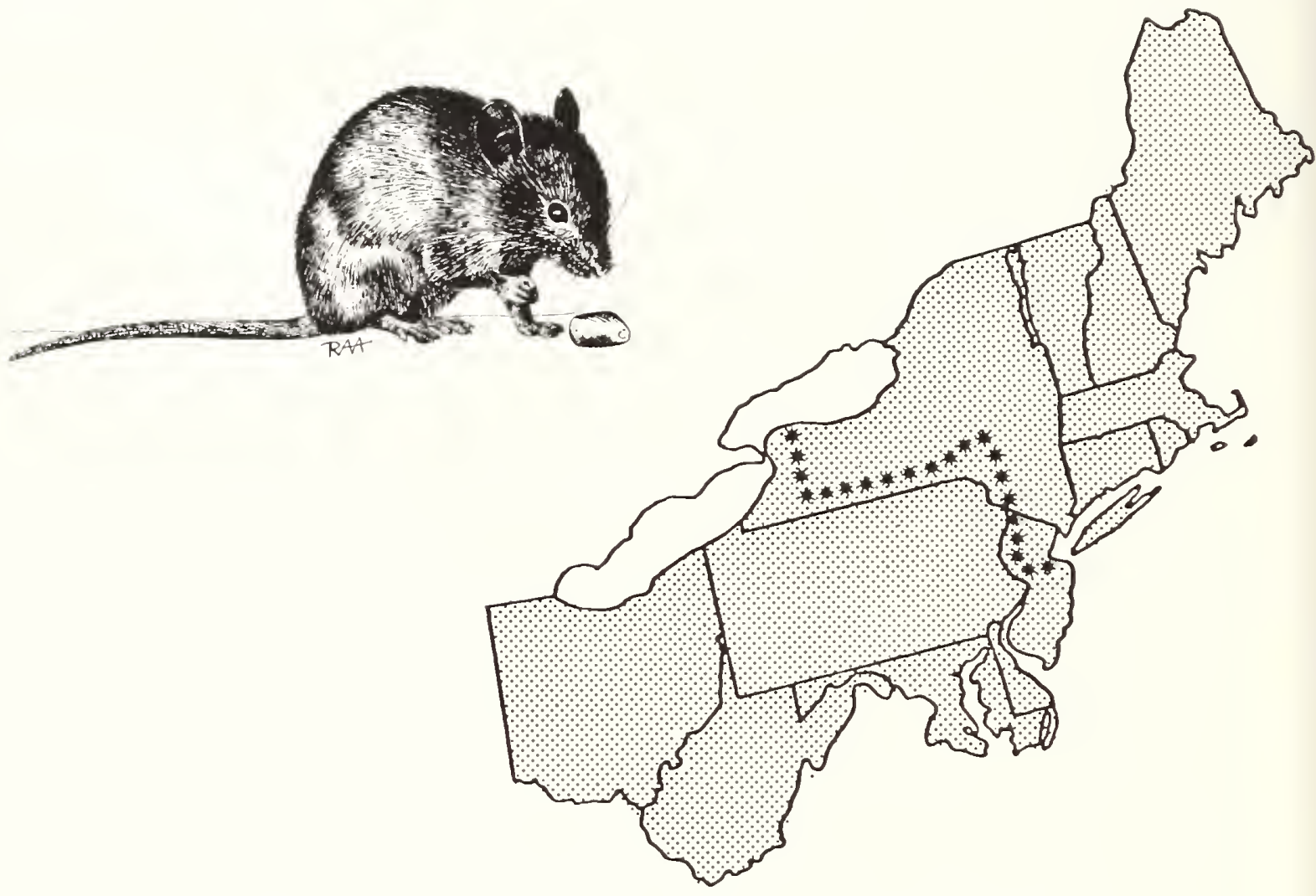

Range: Throughout North America from southern Canada to Mexico.

Relative abundance in the Northeast: Abundant

Habitat in the Northeast: Buildings, fields, corncribs, etc. Often burrows in fields and uses existing mouse runways during warm seasons of year and moves indoors to escape winter cold.

Special habitat requirements: Buildings in winter.

Reproduction

Age at sexual maturity: 8 weeks (females) (Godin 1977:142),

5 weeks (Banfield 1974:224)

Breeding season: Throughout the year

Peak: early spring to late summer

Gestation period: 19 to 21 days

Young born: Throughout the year

Litter size: 3 to 12 , typically 4 or 5

No. litters/year: 5 to 8, typically 6

Home range: Average $1560 \mathrm{ft} .{ }^{2}\left(145 \mathrm{~m}^{2}\right)$ for males and females (Lidicker 1966) in brush-grass habitat (on an island) with high population of Microtus. $3925 \mathrm{ft}^{2}$ ( $365 \mathrm{~m}^{2}$ ) in area with low (1 individual) Microtus population (Quadagno 1968). 
Sample density: Densities of 300 or more mice/acre $(741+/$ ha $)$ were reported on an island (Lidicker 1966).

Food habits: Fruits, grains, seeds, vegetables, plant roots, insects, almost any sweet or high protein food. Occasionally caches food.

Economic status: Non-game. Economically detrimental to man.

Comments: Mainly nocturnal, active throughout the year. Colonial and highly social--may construct communal nests.

Key natural history references: Lidicker 1966, Quadagno 1968, Godin 1977. 


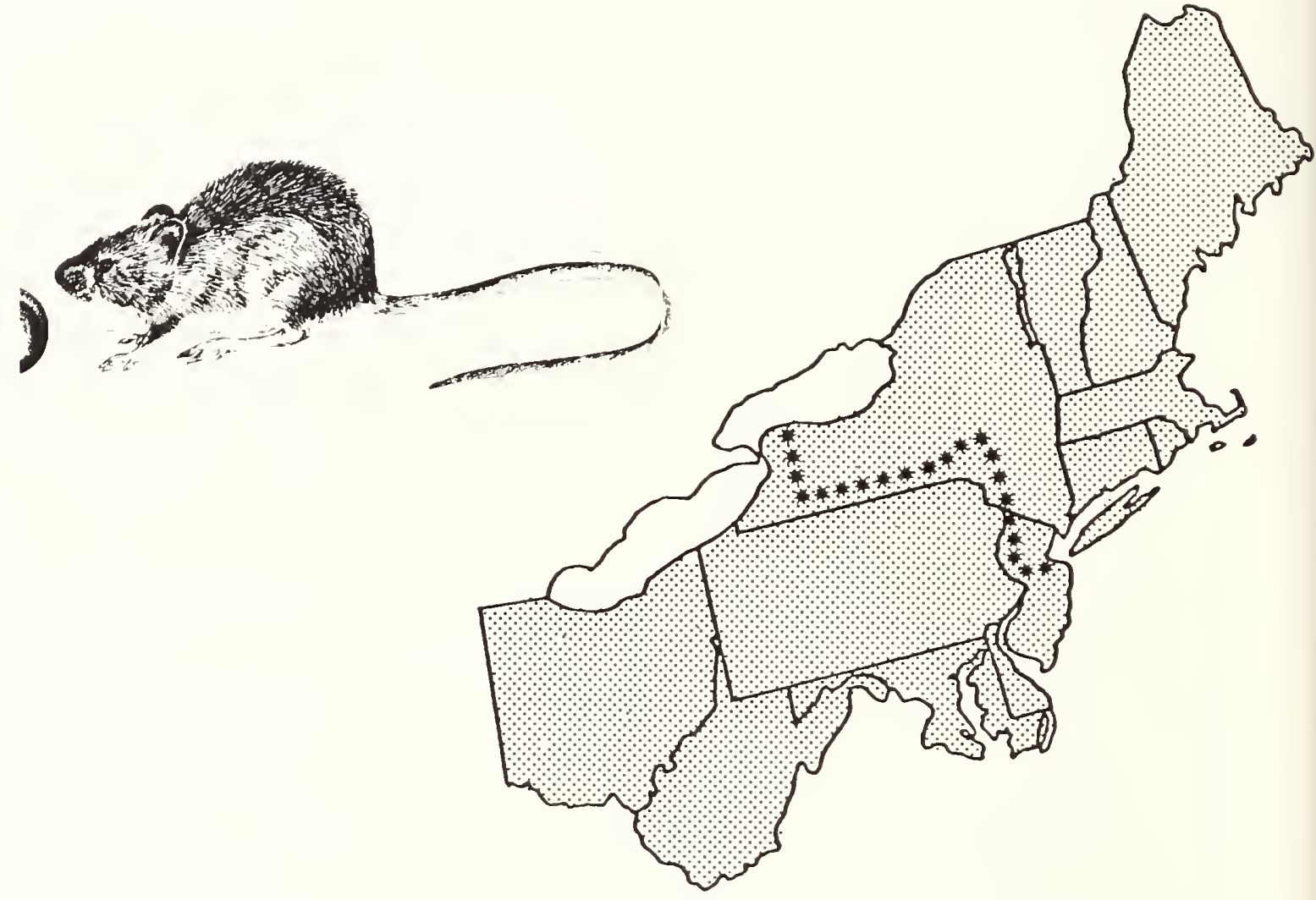

Range: Most of Canada, Alaska and the continental United States, south to northern Georgia and west to Colorado.

Relative abundance in the Northeast: Locally common

Habitat in the Northeast: Moist open grassy and brushy marshes and meadows, willow-alder thickets occurring along water courses, swamps and transition areas between lowlands and wooded uplands (deciduous and mixed), occasionally dry meadows. Appears to prefer areas with numerous shrubs and small trees.

Special habitat requirements: Herbaceous groundcover, loose soils for burrowing.

Reproduction

Age at sexual maturity: Less than 1 year. Young females of first litter may breed during first year (Quimby 1951).

Breeding period: Late April to early September

Peaks: early June, July and August

(Hamilton and Whitaker 1979:248)

Gestation period: 18 days

Young born: May to early October

Litter size: 2 to 8 , average 5 to 6

No. 1itters/year: 2 possibly 3 
Home range: Average 0.38 acre ( 0.15 ha) for females and average 0.43 acre (0.17 ha) for males in Itasca Park in Minnesota (Quimby 1951). Approximately 0.89 acre (0.36 ha) (average) for males and 0.92 acre ( $0.37 \mathrm{ha}$ ) (average) for females in grassy area in Michigan (Blair 1940C).

Food habits: Invertebrates, especially beetles and cutworms are taken in spring followed by seeds, fruits, nuts and subterranean fungi as summer progresses. Feeds on rootlets exposed by stream erosion (Cameron 1958:49).

Economic status: Non-game

Comments: Mainly nocturnal and solitary. Hibernates for longer periods in winter than most mammals (Go din 1977:144) in chambers 1 to 3 feet below ground, usually in a bank or hill (Banfield 1974:227).

Key natural history references: Sheldon 1934, Blair 1940c, Quimby 1951, Whitaker 1963a and 1972b.

117 
Woodland jumping mouse

Rodentia

Myomorpha

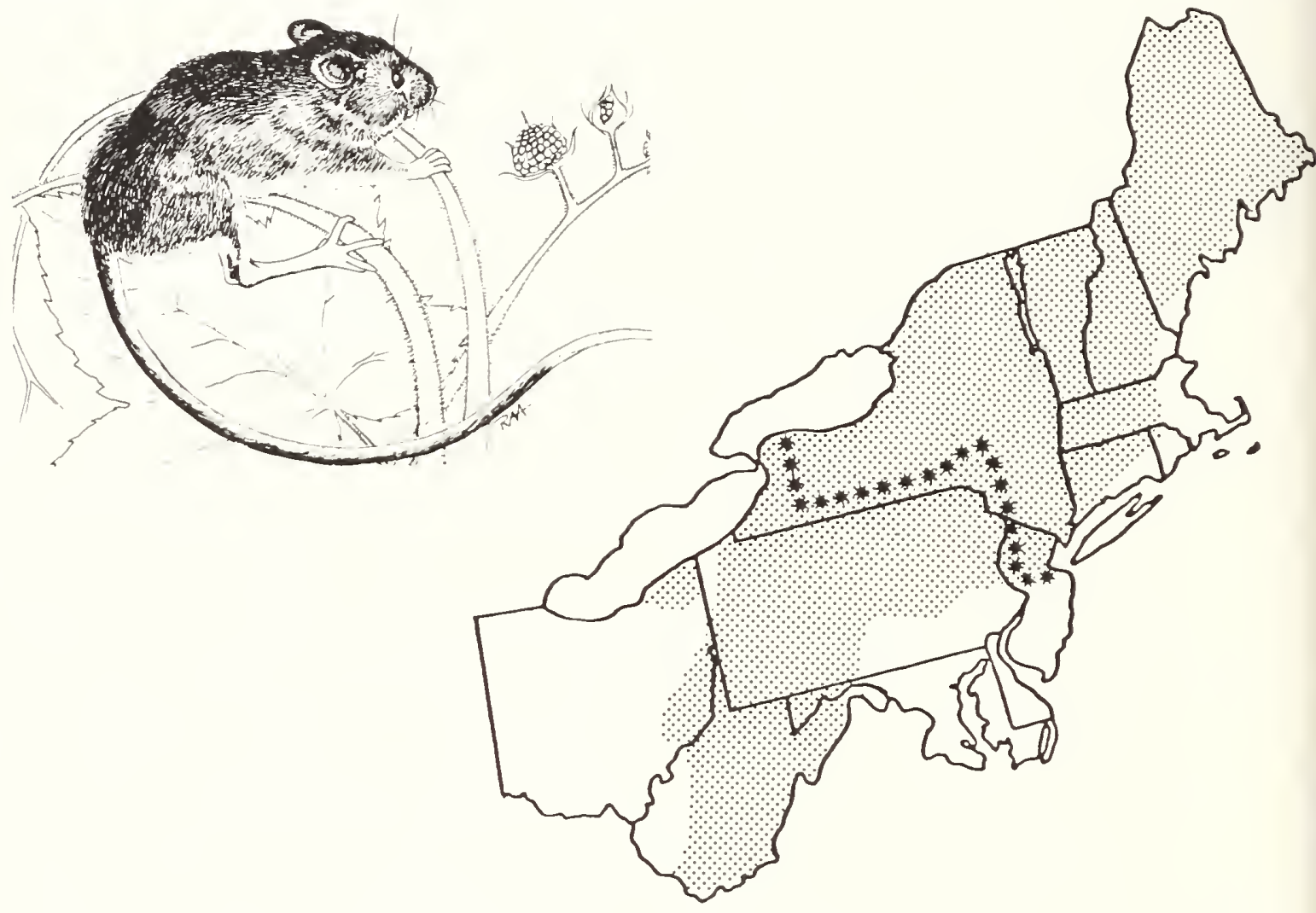

Range: Canadian maritime provinces south to northern New Jersey and western Maryland west to northeastern Ohio.

Relative abundance in the Northeast: Locally common

Habitat in the Northeast: Areas with herbaceous groundcover and low woody plants in both deciduous and coniferous forests, frequently in brush and herbaceous vegetation bordering streams, lakes or ponds. Uses recent clearcuts with herbaceous cover (Kirkland 1977b). Seldom ventures into bare open areas.

Special habitat requirements: Moist cool woodland, loose soils for burrowing, herbaceous cover (Whitaker and Wrigley 1972).

Reproduction

Age at sexual maturity: Possibly as early as 38 days (Layne

Breeding period: May to August and Hamilton 1954)

Gestation period: 21 to 25 days

Young born: Late May to late August. Occasionally a second

1itter born in September (Godin 1977:148)

Litter size: 1 to 8 , typically 5

No. 1itters/year: 1 or 2 
Home range: Average 8.96 acres ( $3.63 \mathrm{ha}$ ) for an adult male and 6.55 acres (2.65 ha) for an adult female (Banfield 1974:230). 1.0 to 6.5 acres $(0.40$ to $2.63 \mathrm{ha})$ for females and 1.0 to 9.0 acres ( 0.40 to 3.64 ha) for males in virgin hardwood forest in Michigan (BTair 1941).

Food habits: Tender parts of herbaceous plants, roots, fruits, underground fungi, seeds, insect larvae and adults. Does not cache food.

Economic status: Non-game

Comments: Nocturnal feeder, hibernates from October or November until April or May. Nest may be built in excavated chamber within burrow system usually about 4 inches $(10 \mathrm{~cm})$ below surface of ground or under log or stump.

Key natural history references: Sheldon 1934 and 1938, Hamilton 1935, Blair 1941, Preble 1956, Whitaker 1963b, Brower and Cade 1966, Wrigley 1972, Lovejoy 1973. 
Porcupine

Rodentia

Hystricomorpha

Erethizon dorsatum

Erethizontidae

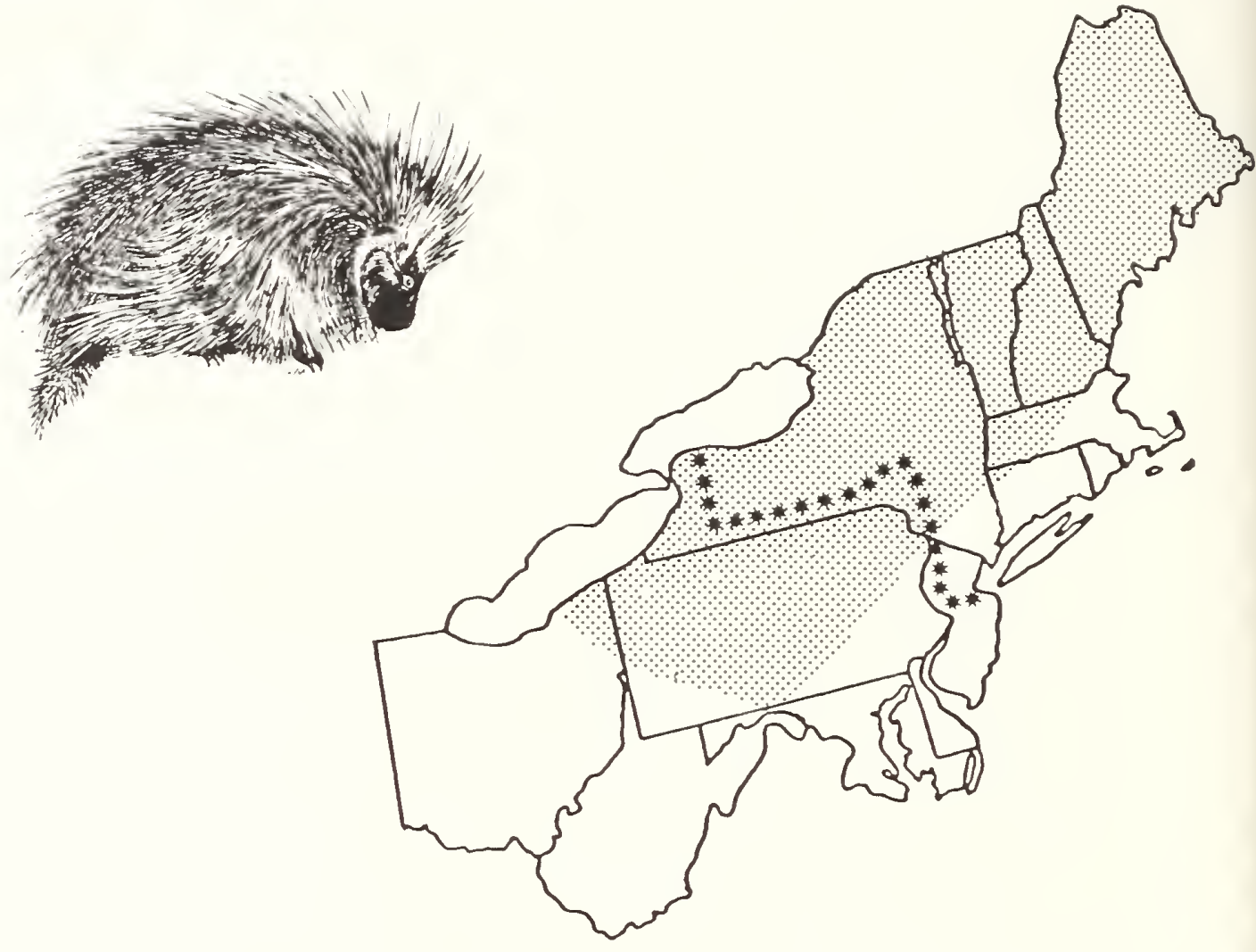

Range: Nova Scotia and Quebec west across boreal Canada to Alaska, south in the Appalachians to northern Virginia; in the Midwest to northern Minnesota and Wisconsin, and in the West to northwestern Texas, Arizona and eastern California.

Relative abundance in the Northeast: Common to uncommon

Habitat in the Northeast: Mixed or coniferous forests especially northern hardwood-hemlock, with adequate denning sites.

Special habitat requirements: Den sites in rock ledges or other protective places, trees.

Reproduction

Age at sexual maturity: 15 to 16 months

Breeding period: October through December, occasionally later

Gestation period: 205 to 217 days, average 210 days

Young born: April to June

Litter size: 1, rarely more

No. litters/year: 1

Home range: Winter ranges averaged 6 acres (2.4 ha) in New Hampshire (Faulkner and Dodge 1962) and 13.3 acres ( $5.4 \mathrm{ha}$ ) in the Adirondacks of New York (Shapiro 1949). Spring and summer ranges varied from 32 to 36 acres ( 13.0 to 14.6 ha) in conifer-hardwood forest in Minnesota (Marsha11, Gullion and Schwab 1962). 
Food habits: Herbaceous and woody vegetation. Eats large quantities of grasses, leaves, twigs, buds, mast and bark. Is especially fond of the bark of hardwood trees.

Economic status: Non-game. May damage commerically-grown trees or buildings.

Comments: Mainly nocturnal, remaining active throughout the year. Den may be in rocky cavern of ledge, in hollow log, abandoned building or abandoned fox or beaver den. Generally is solitary throughout the year.

Key natural history references: Curtis and Kozicky 1944, Shapiro 1949, Costel10 1966, Dodge 1967. 


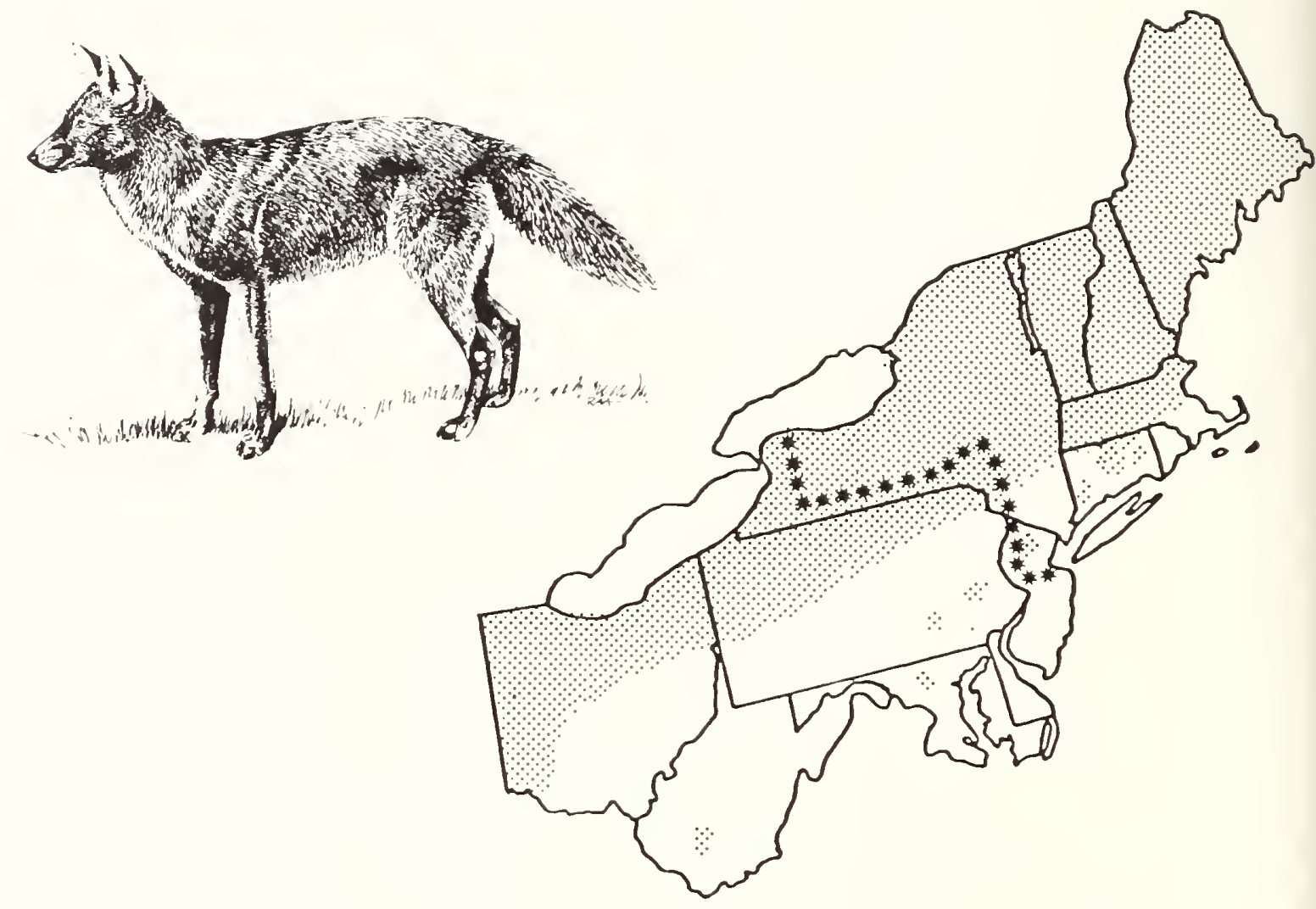

Range: New England (except Rhode Island), New York, northern Pennsylvania, northern Ohio, south to Texas and west to California.

Relative abundance in the Northeast: Uncommon

Habitat in the Northeast: Edges of second growth forests, open brushy fields, fallow agricultural land, forest openings created by fire or logging.

Winter habitat: Coyotes may concentrate in low-lying areas with abundant snowshoe hares and deer (Ozoga and Harger 1966).

Special habitat requirements: Open country for hunting, secluded den sites.

Reproduction

Age at sexual maturity: 1 to 2 years

Breeding period: February (in northern part of range)

Gestation period: 60 to 65 days

Young born: April or May

Litter size: 4 to 8 , occasionally more, typically 5 to 7 
Home range: Size may exceed an area 5 miles $(8 \mathrm{~km})$ in diameter depending on food supply and time of year (Godin 1977). Range sizes of radio-tracked individuals were greater for males (average $68 \mathrm{~km}^{2}, 26.3 \mathrm{mi}^{2}$ ) than females $\left(16 \mathrm{~km}^{2}\right.$, $6.3 \mathrm{mi}^{2}$ ) in Minnesota (Berg and Chesness 1978).

Sample density: The winter density of coyotes on an island in Lake Michigan was estimated at 1 animal/2 square miles $\left(5.2 \mathrm{~km}^{2}\right.$ ) (Ozoga and Harger 1966).

Food habits: Opportunistic feeders consuming mainly carrion, smal1 Tive vertebrates, invertebrates and vegetation. Winter food in the Northeast is mainly snowshoe hare and carrion of deer.

Economic status: Furbearer, game. Protected in some northeastern states.

Comments: Mainly crepuscular and nocturnal, hunting along or in small packs. Den is usually in an excavated burrow that is wellhidden by vegetation, a rock or stump.

Key natural history references: Stebler 1951, Ozoga and Harger 1966, Banfield 1974, Bekoff 1977 and 1978, Hilton 1978. 


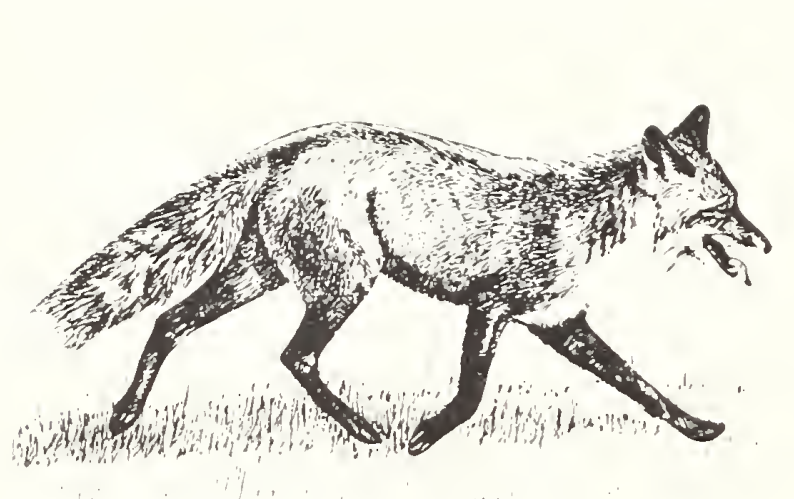

Canidae

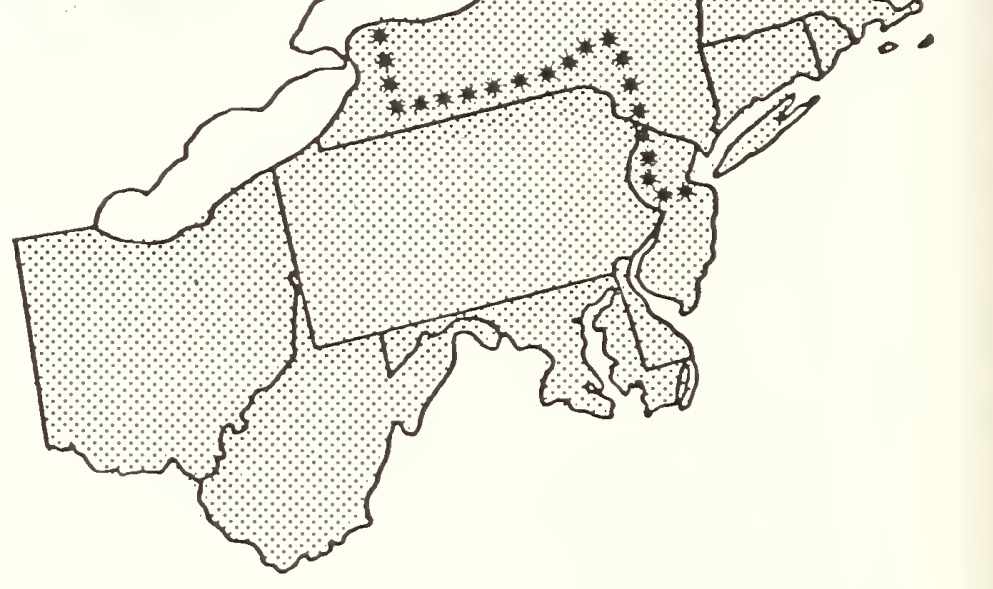

Range: North America from Baffin Island south to central Texas, excluding southeastern U.S., the west coast from Canada to California, the southwestern desert, and the Great Plains.

Relative abundance in the Northeast: Common to uncommon

Habitat in the Northeast: Found in a variety of habitats. A mixture of forest and open areas is preferred. Unbroken fields and dense forests avoided.

Special habitat requirements: Suitable den sites.

\section{Reproduction}

Age at sexual maturity: Winter after their birth

Breeding period: Mid-January to late February, sometimes extending to March. Peak: Late January

Gestation period: 51 to 56 days, average 53 days

Young born: March or April

Litter size: 1 to 10 , average 4 or 5 
Home range: Less than 3 miles $(4.8 \mathrm{~km}$ ) in diameter (Scott 1943, Storm 1965, Ables 1969, Sargeant 1972). Phillips et al (1972) found that $70 \%$ of the juvenile males on study areas in Iowa and I1linois and 30\% of the females moved more than 5 miles $(8 \mathrm{~km})$ from their natal ranges during their first year. Distances of 15 to 20 miles (24 to $32 \mathrm{~km}$ ) were common. Home range is shared by a male-female pair and seasonally by their pups (Scott 1943, Sargeant 1972).

Food habits: Opportunistic feeder consuming animals ranging from insects to smal1 mammals. Commonly takes birds, turtles, frogs, snakes and their eggs. Berries and fruits are eaten when available. Surplus food may be buried or cached under snow and marked with urine.

Economic status: Furbearer

Comments: May dig dens but prefers to use existing burrows for rearing young and escaping predators. Red fox dens may have an underground tunnel system 25 feet ( $8 \mathrm{~m}$ ) long or more (Godin 1977:203).

Key natural history references: Seton 1929, Seagears 1944, Godin 1977. 


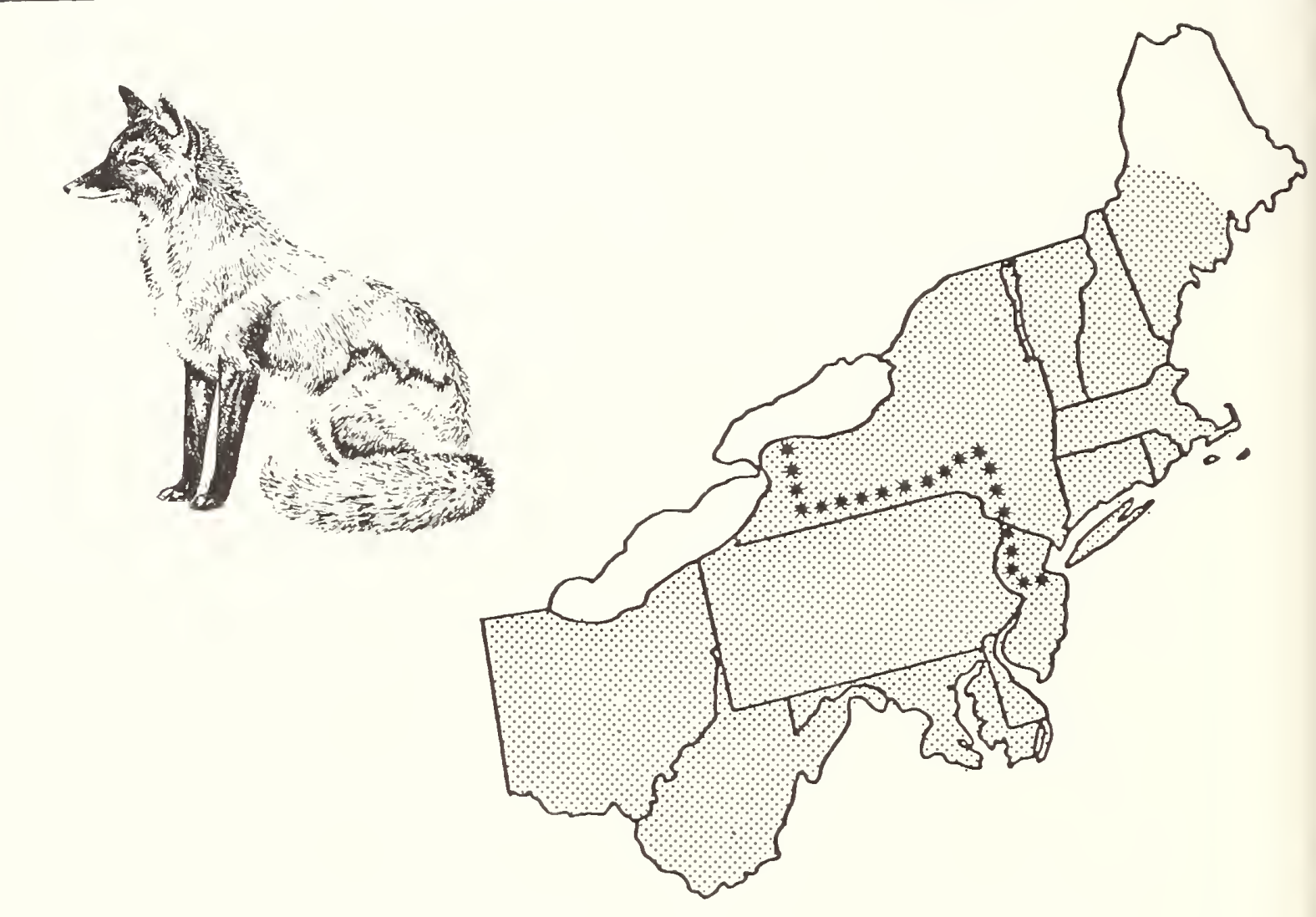

Range: Throughout the United States except Idaho, Montana, Wyoming, most of Washington, and the western plains south to Texas. Recently extended north to southeastern Canada.

Relative abundance in the Northeast: Common to uncommon. Presentiy is reoccupying range in New England.

Habitat in the Northeast: Dense northern hardwood or mixed forests. May inhabit thickets and swamps.

Special habitat requirements: Den sites such as hollow logs, tree cavities, rock crevices or cavities beneath deserted buildings, rarely in ground burrows.

Reproduction

Age at sexual maturity: First year after birth Breeding period: Mid-January to May

Peak: early March (1atitude dependent)

Gestation period: 51 to 63 days, average 53 days

Young born: March or April

Litter size: 2 to 7 pups, average 3 to 5 
Home range: Varies with food supply, disturbances, denning, and season. Range varies from a mile $(1.6 \mathrm{~km})$ wide during denning to 5 miles $(8 \mathrm{~km}$ ) in the fall (Godin 1977:206).

Food habits: Crepuscular and nocturnal. Chiefly small mammals but includes birds, reptiles and amphibians and their eggs. Acorns, insects, fruits and carrion are also eaten.

Economic status: Furbearer

Comments: Hunts prey and escapes enemies by climbing trees. The northward spread corresponds to that of the cottontail.

Key natural history references: Sullivan 1956, Burt and Grossenheider 1976, Godin 1977. 


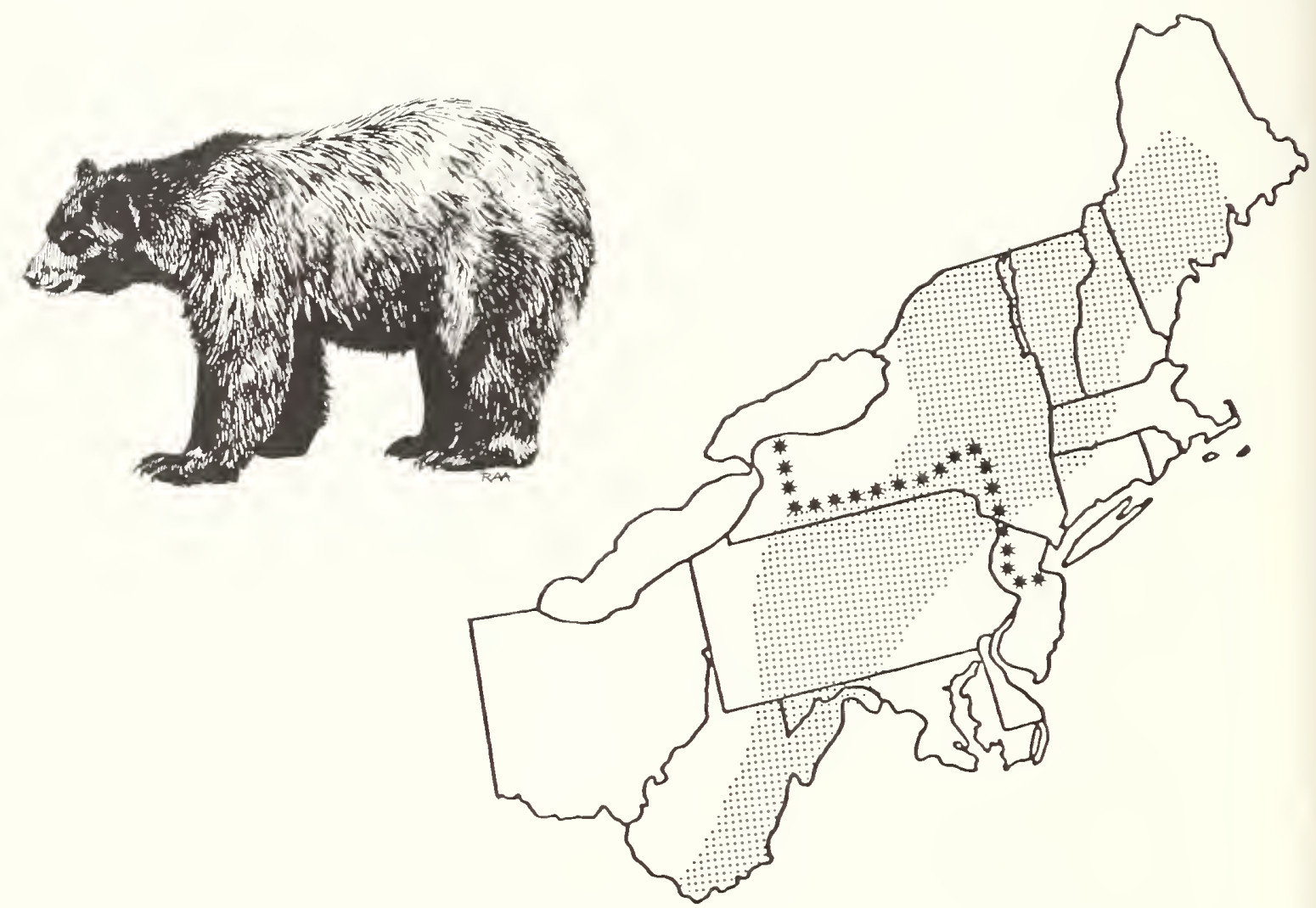

Range: Throughout Canada except the northern coast. In the U.S. it occurs in the Sierras, Idaho and Montana, south through the Rockies into Mexico, northern Great Lakes area, Ozarks, Gulf Coast, Florida and New England south through the Appalachians to northern Georgia.

Relative abundance in the Northeast: Common in north to uncommon farther south.

Habitat in the Northeast: Primarily in wilderness forests and swamps. Prefers mixed deciduous-coniferous woodlands with a thick understory.

Special habitat requirements: Den sites located under fallen trees, in hollow logs, rock ledges, slash piles or other protected areas.

$\underline{\text { Reproduction }}$

Age at sexual maturity: Females: $3-1 / 2$ years

Breeding period: Early June through mid-July

Peak: mid-June

Gestation period: 7 to 7-1/2 months, average 220 days

Young born: About February 1

Litter size: 1 to 5 , average 2 (varies with year and locality, females breed once every 2 years) 
Home range: Home range size varies with many factors and is presently unknown. There is probably a greater seasonal range in the male black bear than the female (Godin 1977:209). Most widely accepted range is a $15 \mathrm{mile}(24 \mathrm{~km})$ average radius for adult males and a somewhat smaller radius for females (Cahalane 1947).

Food habits: Onmivorous feeder consuming insects, especially grubs and ants under the bark of rotten logs and stumps, mice, frogs, fish, acorns and beechnuts, apples and numerous berries. Also takes carrion and garbage.

Economic status: Game

Comments: Nocturna 1. Trails are used repeatedly and prominent trees are often marked by either sex by clawing and ripping off bark. Several individuals may mark the same tree. Usually solitary except mother and cubs. Cubs are born during the winter while the female is in the den. At birth they weigh less than 1 pound $(448 \mathrm{~g})$ and are poorly developed. Female shares den with cubs the first winter after their birth. Both sexes are inactive (semi-hibernate) during coldest months of the year.

Key natural history references: Spencer 1961, Jonke1 and Cowan 1971, Banfield 1974, Burt and Grossenheider 1976, Cardoza 1976, Godin 1977. 


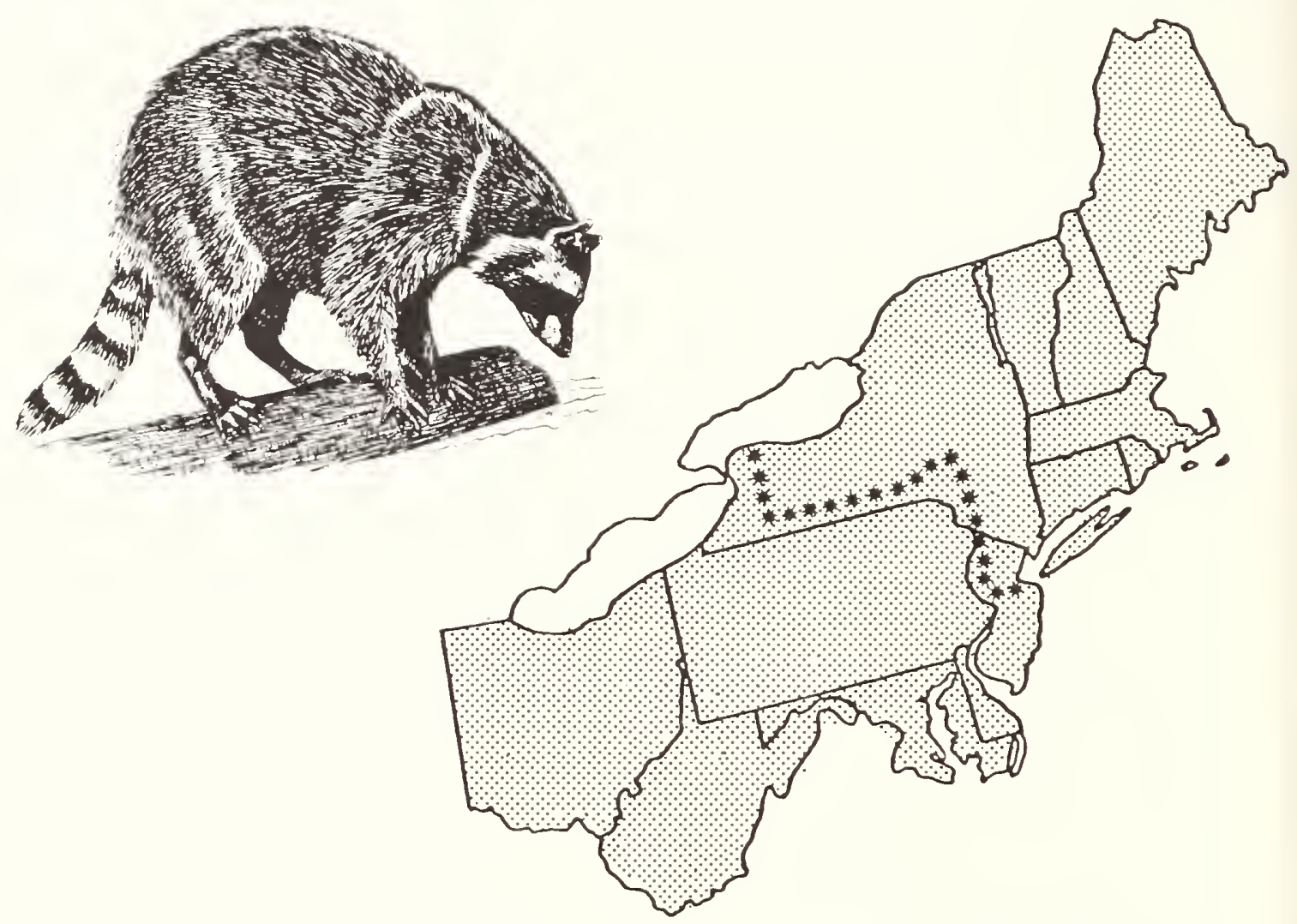

Range: Throughout most of southern Canada and the U.S. except for the deserts of the Southwest and higher elevations of the Rocky Mountains. Also occurs from Mexico to Panama.

Relative abundance in the Northeast: Common

Habitat in the Northeast: Wooded areas interrupted by fields and water courses. Not usually found in dense forests, commonly found in wetlands near human habitation.

Special habitat requirements: A den in any protected area from a culvert to an abandoned woodchuck burrow. Prefers hollow trees. Dens are usually located in trees 10 feet $(3 \mathrm{~m})$ or more above ground (Banfield 1974:314).

Reproduction

Age at sexual maturity: $50 \%$ of females breed as yearlings

(Stuewer 1942); remaining breed when two years old

Breeding period: Late January to mid-March

Gestation period: About 63 days

Young born: Late April to early May (if the female is not

fertilized, a second breeding cycle may begin

2 to 4 months later (Whitney and Underwood 1952). 
Litter size: 3 to 7 cubs, average 4

No. 1itters/year: 1

Home range: The home range is usually less than 2 miles $(1.6 \mathrm{~km}$ ) in diameter (Burt and Grossenheider 1976:51). Size varies with the individual, food availability and weather. Raccoons have traveled up to 165 miles $(264 \mathrm{~km}$ ) in 164 days (Lynch 1967).

Food habits: Omnivorous. Animal matter is the major food in spring and early summer. Fruits and seeds are eaten in summer, fall and winter. Crayfish, worms, insects, carrion, tender buds and shoots, grass and garbage are typical foods of the raccoon's diet.

Economic status: Game, forbearer

Comments: Primarily nocturnal, may be seen in daylight. Dormant through the winter remaining in dens but not hibernating. An entire family may den together. Expert climber.

Key natural history references: Hamilton 1936, Stuewer 1942, Godin 1977, Lotze and Anderson 1979.

131 


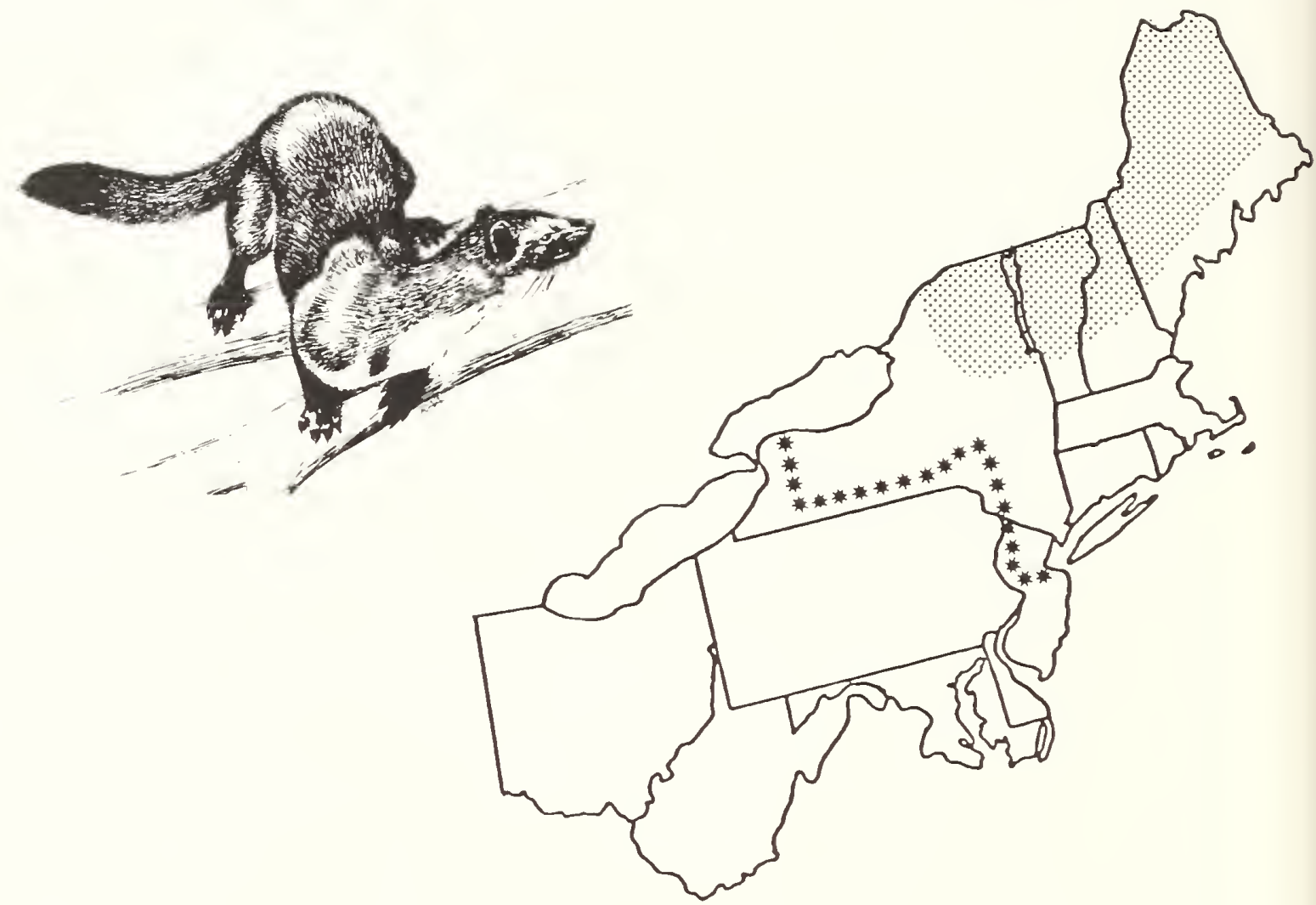

Range: Boreal forests of Canada to Alaska south in the Cascade-Sierra Nevada ranges, and the Rockies into New Mexico; extreme northern Minnesota and Wisconsin and northern New England and New York.

Relative abundance in the Northeast: Uncommon

Habitat in the Northeast: Coniferous forests of fir, spruce and hemlock, dense mixed hardwood-conifer forests, cedar swamps.

Special habitat requirements: Den sites (hollow trees or logs are most commonly used). Martens appear to have no permanent den site (God in 1977:217).

Reproduction

Age at sexual maturity: Females: 2 to 3 years old Males: 1 year

Breeding period: Mid-summer. Peak: July

Gestation period: 259 to 275 days, 27 day delayed implantation Young born: Early April to mid-May

Litter size: 1 to 5, typically 3 to 4 
Home range: Average home range is $1 \mathrm{mi}^{2}\left(2.6 \mathrm{~km}^{2}\right)$ for males and $0.25 \mathrm{mi}^{2}\left(0.65 \mathrm{~km}^{2}\right)$ for females (God in 1977:218). Adults have been found to range up to $15 \mathrm{mi}^{2}\left(39 \mathrm{~km}^{2}\right.$ ) (Marshail 1951). A seasonal altitudinal migration may occur in the mountains (Banfield 1974:316).

Food habits: Small mammals, especially red squirrels, chipmunks, voles and mice (staples). Snowshoe hare, grouse, smal1 birds and their eggs, insects and fruits are taken when available, and frogs, toads, reptiles and carrion are also eaten. Active night and day during all seasons.

Economic status: Furbearer, protected in some areas

Comments: Martens are easily trapped, which may partially explain their decline in the Northeast. Loss of habitat through logging, burning and land clearing are factors contributing to the range and population decrease (Godin 1977:217). Currently being reintroduced into the White Mountain National Forest of New Hampshire. This species is commonly called pine marten.

Key natural history references: Burt 1957, Banfield 1974, Burt and Grossenheider 1976, God in 1977. 


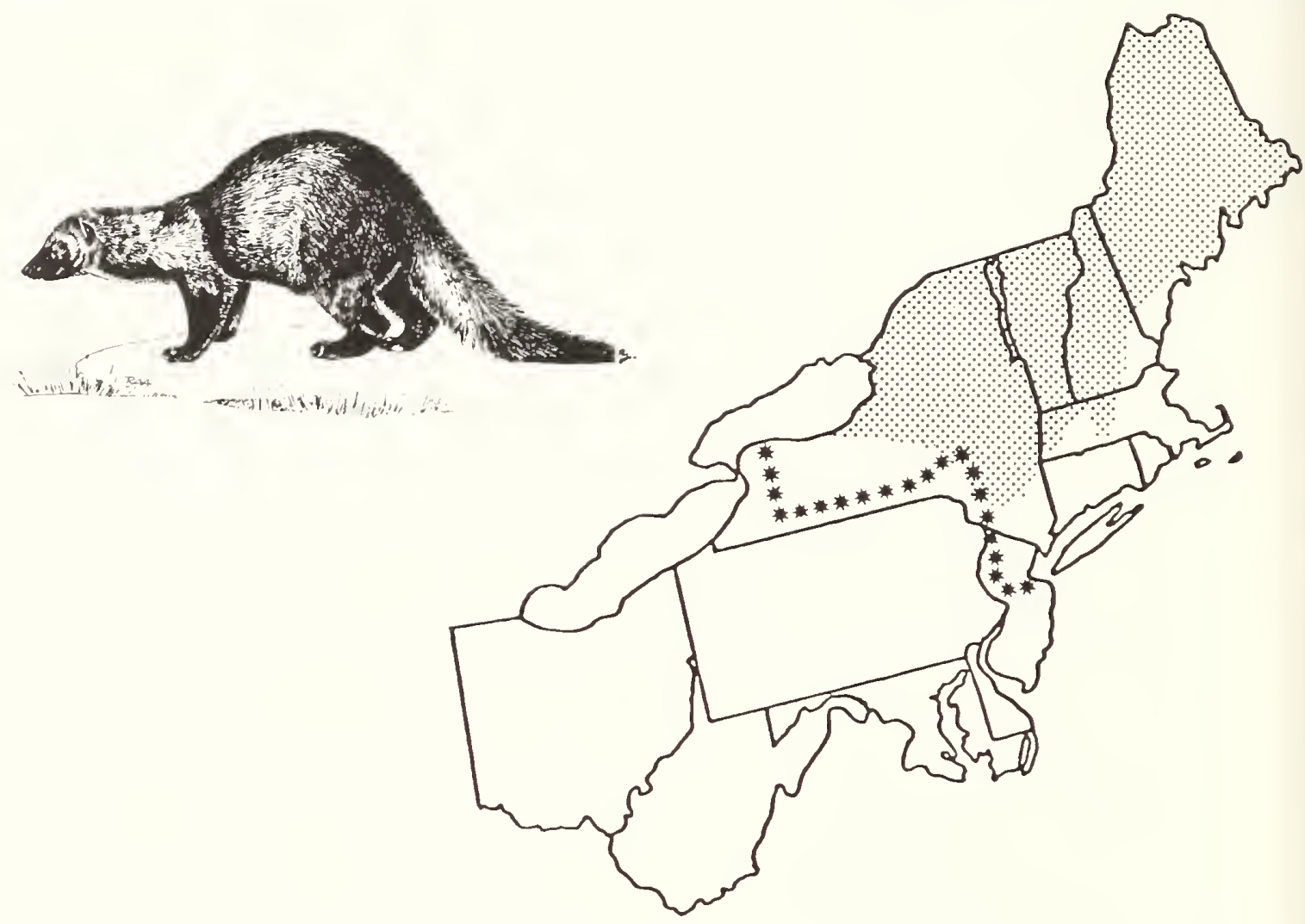

Range: Southeastern Labrador west to southeastern Alaska south in the Sierra Nevadas of California and the Rocky Mountains to Wyoming. Also in northern Minnesota, the Adirondacks of New York and the mountain ranges of New England. It is reoccupying former range in Northeast.

Relative abundance in the Northeast: Probably common to uncommon Habitat in the Northeast: Extensive forests of mixed hardwoods and conifers. Found less frequently in more open stands or burned areas. Favors wetlands (alder) and mixed softwood-hardwood forest types (Kelly 1977:77).

Special habitat requirements: Dens in hollow trees, logs, ground holes under large boulders or abandoned porcupine dens. Rarely digs burrow. Dens may be lined with leaves and are often used as temporary shelters during winter storms; does not hibernate.

Reproduction

Age at sexual maturity: Both sexes become mature before their twelfth month of age. Females produce first litter when 2 years old (Wright and Coulter 1967)

Breeding period: Late February to April

Peak: March 
Gestation period: About 51 weeks, with implantation delayed 9 to 10 months; average 51 weeks

Young born: March to early April

Litter size: 1 to 4 kits, average 3

Home range: Kelly (1978) found that yearly ranges averaged 4,747 acres

(1922 ha) and monthly ranges averaged 2,794 acres (1131 ha)

in northern New Hampshire. Home range size varied from 8 to

15 miles (12.8 to $24.0 \mathrm{~km}$ ) in diameter (Jackson 1961). Hunting circuits may be 60 miles $(96 \mathrm{~km}$ ) in length (Banfield 1974:319). Males range farther than females. Fishers commonly travel along ridges crossing smal1 streams to reach the next ridge (Coulter 1959).

Food habits: About $80 \%$ of the fisher's diet is mammals (Banfield 1974:319). They are opportunists taking shrews, mice, squirre1s, birds, toads, insects, berries, nuts and carrion. Porcupines are common and preferred prey of fishers.

Economic status: Furbearer, protected in some areas

Comments: Fishers are good climbers and are as agile in trees as on ground. Active both day and night, throughout the year.

Key natural history references: Burt 1957, Coulter 1966, Banfield 1974, Godin 1977, Ke17y 1977. 


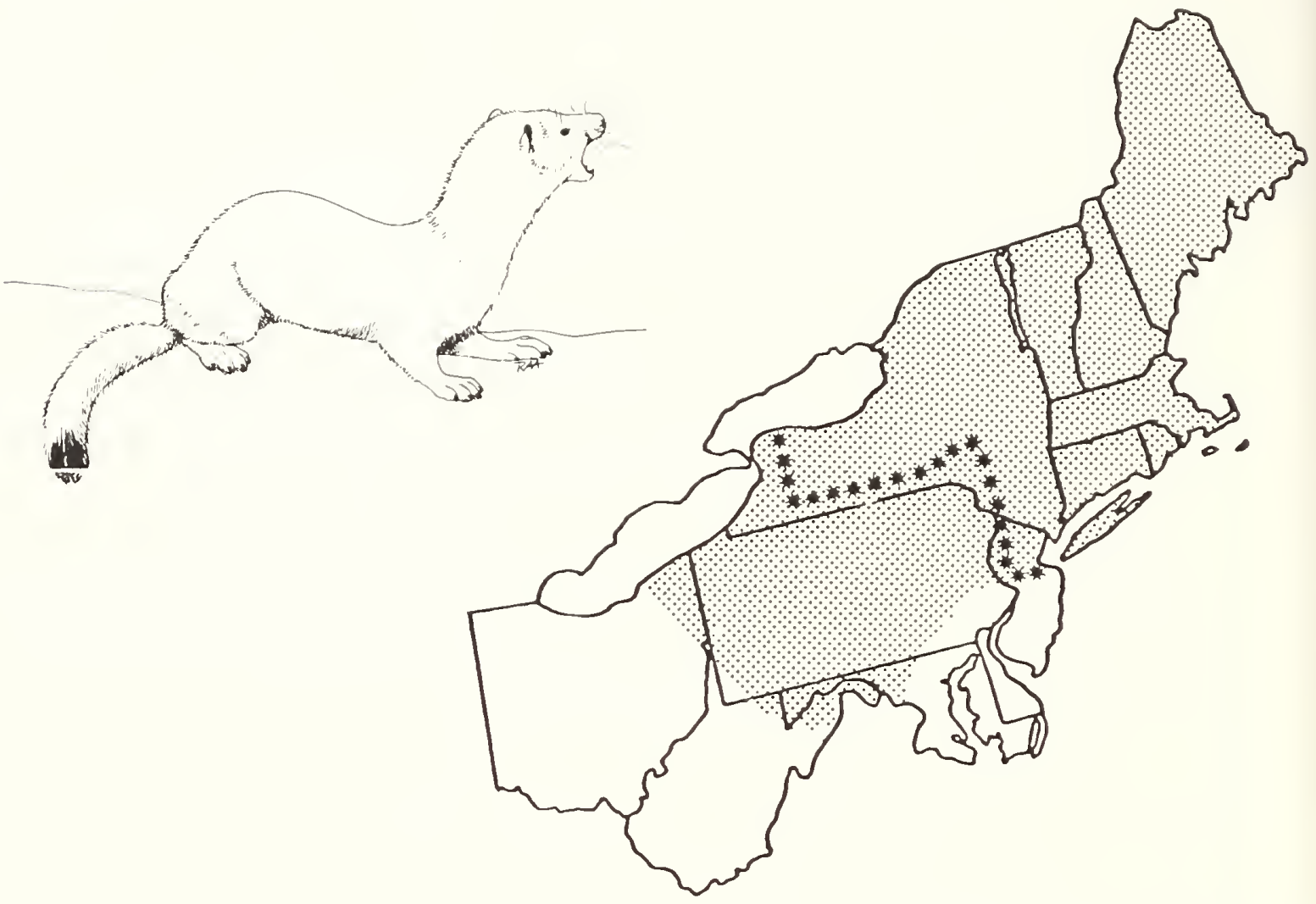

Range: Throughout Alaska and most of Canada, south in the U.S. to southern Pennsylvania and western Maryland, the Great Lakes region and the northwestern quarter of the country.

Relative abundance in the Northeast: Common to uncommon

Habitat in the Northeast: Wooded or open country with thickets, rock piles or other heavy cover; often close to watercourses.

Special habitat requirements: Small rodents, dense brushy cover.

Reproduction

Age at sexual maturity: Males: probably 1 year

Females: 3 or 4 months

Breeding period: July or August

(Jackson 1961:341)

Gestation period: Possibly 9 months (Hamilton 1933b),

Young born: Mid-April to early May about 255 days (Jackson 1961:341).

Litter size: 4 to 9 , typically 6 or 7

Home range: Approximately 30 to 40 acres (12.1 to 16.2 ha) under normal conditions but may extend for 2 or 3 linear miles (3.2 to $4.8 \mathrm{~km}$ ) per night during periods of food shortage (Jackson 1961:341). 
Sample density: May reach 20 individuals $/ \mathrm{mi}^{2}\left(8 / \mathrm{km}^{2}\right)$ in favorable habitat (Jackson 1961:341).

Food habits: Mice (staple), chipmunks, moles and shrews, occasionally birds and insects, and rarely snakes, frogs or fish.

Economic status: Furbearer

Comments: Den is usually below ground under fallen tree or stump but may also be in abandoned building, stone wall, hollow log or almost anywhere there is a small dry enclosure. Nocturnal and active throughout the year. Molts to white in winter throughout the Northeast.

Key natural history references: Hamilton 1933b, Hal1 1951, Jackson 1961. 


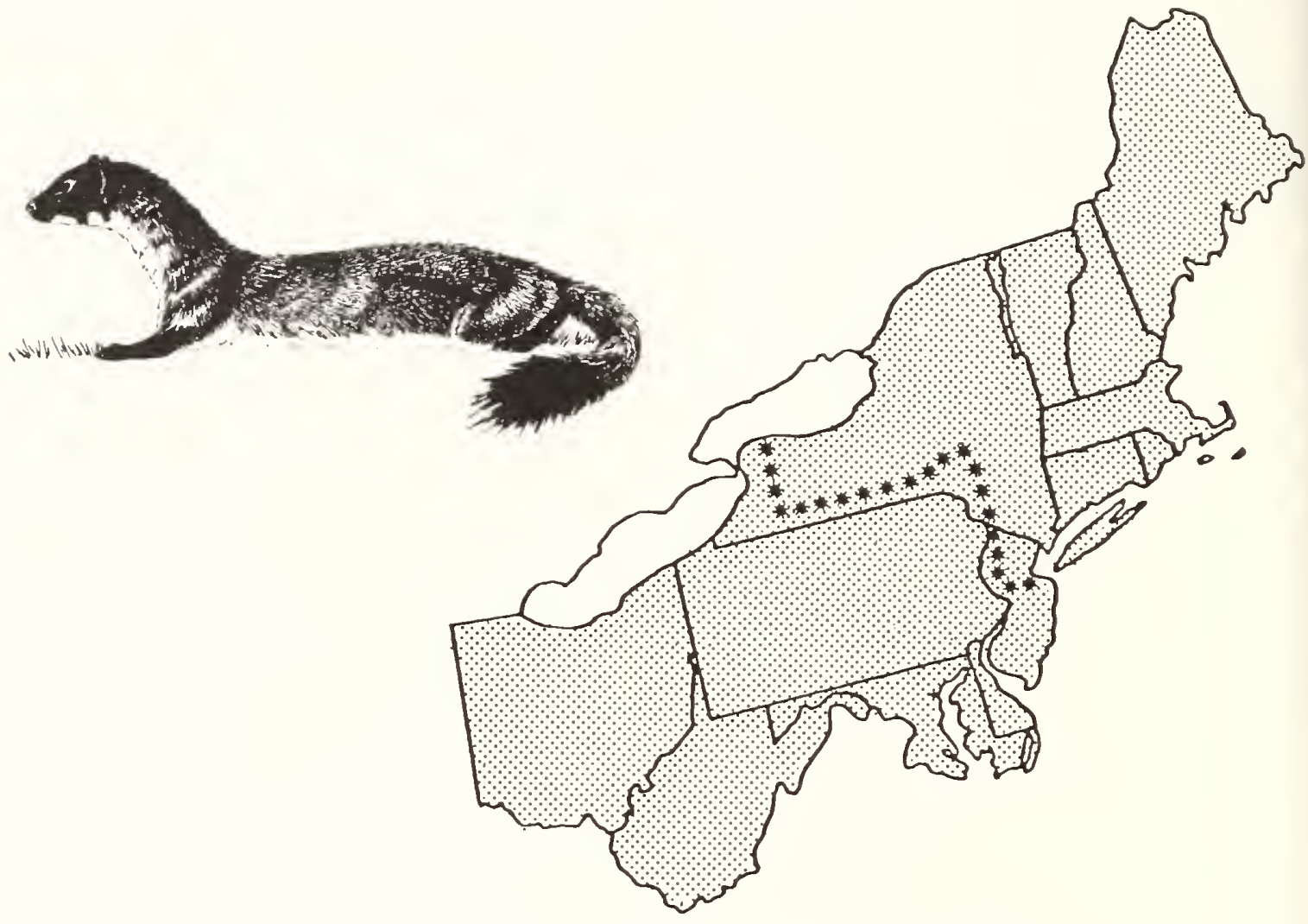

Range: Southern Canada to South America. Not found in the southwestern desert of the U.S., northwestern Mexico or the Baja Peninsula.

Relative abundance in the Northeast: Common to uncommon

Habitat in the Northeast: Open woods and woodland edges, grasslands, river bottomlands, fencerows. Found in elevations from sea level to the alpine tundra zone. Prefers to be near water.

Special habitat requirements: Uses previously excavated burrows or natural holes or crevices for dens.

Reproduction

Age at sexual maturity: Females: 3 to 4 months

Males: 1 year

Breeding period: July to August

Gestation period: 205 to 337 days, average 279 days (Wright 1942) (approximately 7-1/2 months delayed implantation)

Young born: April to May

Litter size: 1 to 12, average 6 to 9 (Wright 1948) 
Home range: Size varies with food availability and cover type. Studies in Wisconsin showed ranges of 30 to 40 acres

(12.1 to $16.2 \mathrm{ha}$ ) (Jackson 1961) and in Missouri, 400 acres (162 ha) (Schwartz and Schwartz 1959). About 300 acres (121.5 ha) in mixed agricultural-wooded-marsh habitat in southern Michigan. Average cruising radius was 0.3 miles $(0.5 \mathrm{~km})$ from den and the average daity distance traveled by one large male was 2 linear miles $(3.2 \mathrm{~km})$ (Quick 1944).

Food habits: Primarily small mammals; some birds, especially ground nesting species; few insects and an occasional snake. Sma 11 prey is eaten entirely. May climb trees to catch prey.

Economic status: Furbearer

Comments: Active year long; mainly nocturnal. Some individuals turn white in winter where climate is cold. Molting occurs from mid-October to mid-November and mid-February to mid-April.

Key natural history references: Hamilton 1933b, Ha11 1951, Banfield 1974, Burt and Grossenheider 1976, Godin 1977. 


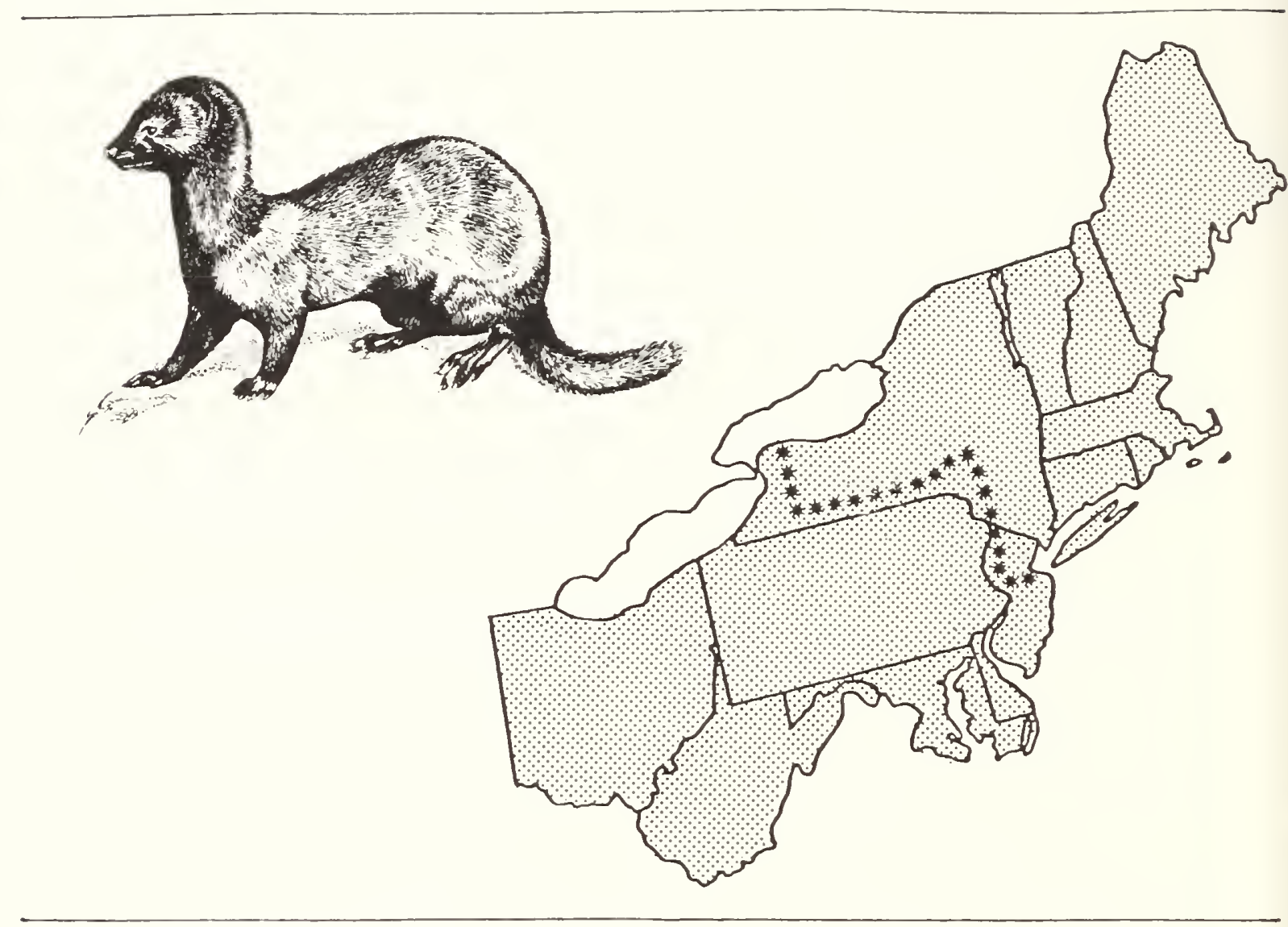

Mustelidae

Range: Canada (except high Arctic) west through Alaska and south throughout the U.S. (except the southwestern deserts).

Relative abundance in the Northeast: Common to uncommon

Habitat in the Northeast: Streambanks, lakeshores, and marshes.

Favors forested wetlands with abundant cover such as thickets, rocks or windfalls.

Special habitat requirements: Den sites inside hollow logs, natural cavities under tree roots or in burrows along stream, marsh or lake edges.

Reproduction

Age at sexual maturity: 10 months

Breeding period: Late February to early April

Peak: March (Mitche11 1961)

Gestation period: 40 to 75 days, average 51 days, 30 to 32

Young born: April or May day delayed implantation (Enders 1952)

Litter size: 2 to 10 kits, average 3 to 4 
Home range: The average range is 2 to 3 miles $(3.2$ to $4.8 \mathrm{~km}$ ) in diameter for males along river in Montana. Two females had home ranges of 19.3 and 50.4 acres ( 7.8 and 20.4 ha) in similar river habitat. Long distance travel is common along waterways, and in winter mink may swim under the ice. Home ranges often overlap between juveniles and adults (Mitchel 1961).

Food habits: Small mammals, particularly muskrats, voles, rabbits, fish, frogs, salamanders, crawfish, clams and insects. Trails prey by scent and often caches food.

Economic status: Forbearer

Comments: Molts twice a year. Mainly nocturnal, active year-long. Key natural history references: Mitchell 1961, Banfield 1974, Burt and Grossenheider 1976, Godin 1977.

141 


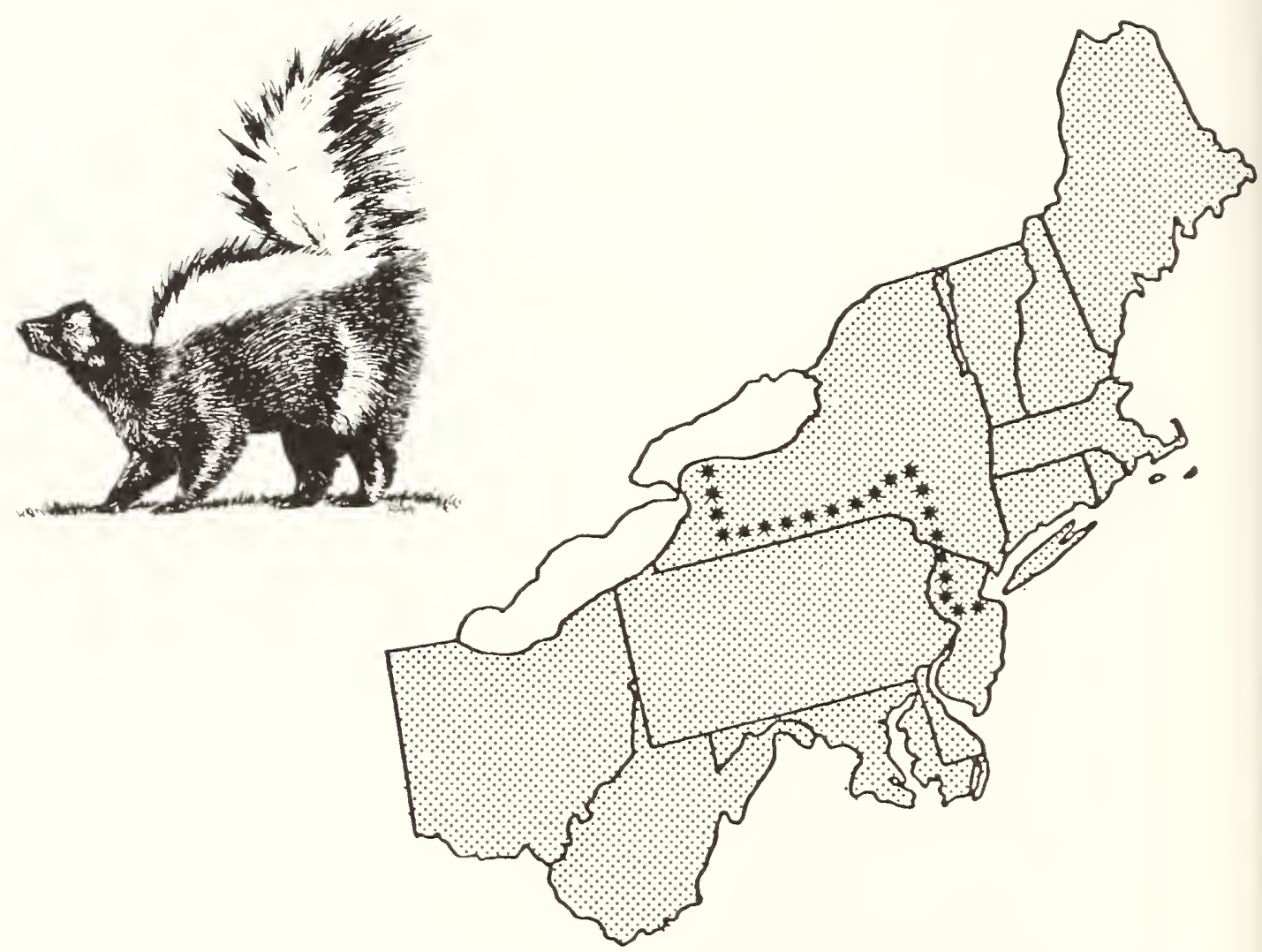

Range: Occurs throughout southern Canada, except coastal British Columbia and throughout the U.S. except the desert regions of the Southwest.

Relative abundance in the Northeast: Common

Habitat in the Northeast: Semi-open country, woods and meadows, agricultural lands, suburban areas and trash dumps. Occurs from sea level to timberline.

Special habitat requirements: Dens that may be under houses, stumps, in stone walls, rock cavities or abandoned burrows.

Reproduction

Age at sexual maturity: Spring following birth (Verts 1967). Breeding period: February to late March

Peak: Mid-February

Gestation period: 62 to 68 days

Young born: Late April to early June

Litter size: 2 to 10 kits, typically 6 or 7

Home range; Nightly movements between 0.25 and $0.50 \mathrm{mi}^{2}(0.6$ to 1.35 $\mathrm{km}^{2}$ ) increasing to 4 or $5 \mathrm{mi}^{2}\left(10.4\right.$ or $13 \mathrm{~km}^{2}$ ) at night during breeding season (Schwartz and Schwartz 1959). 
Sample density: 31 skunks $/ \mathrm{mi}^{2}\left(12 / \mathrm{km}^{2}\right)$ during autumn peak on a $1.13 \mathrm{mi}^{2}$ $\left(2.93 \mathrm{~km}^{2}\right)$ area of farmland, shrub and wooded ravine habitat in Pennsylvania (Jones 1939). $58 / \mathrm{mi}^{2}\left(22 / \mathrm{km}^{2}\right)$ in winter on good habitat in Michigan (Burt 1948:149).

Food habits: Omnivorous diet includes insects, snails, small rodents, birds eggs, fruits, grains, nuts, corn, grasses, buds, berries, garbage and carrion. In summer their diet may consist of as much as 43\% insects (Banfield 1974:339).

Economic status: Furbearer

Comments: Semi-hibernates during the winter months; young may remain in den with mother. Crepuscular or nocturnal, sometimes active during daylight hours.

Key natural history references: Verts 1967, Banfield 1974, Burt and Grossenheider 1976, Godin 1977. 


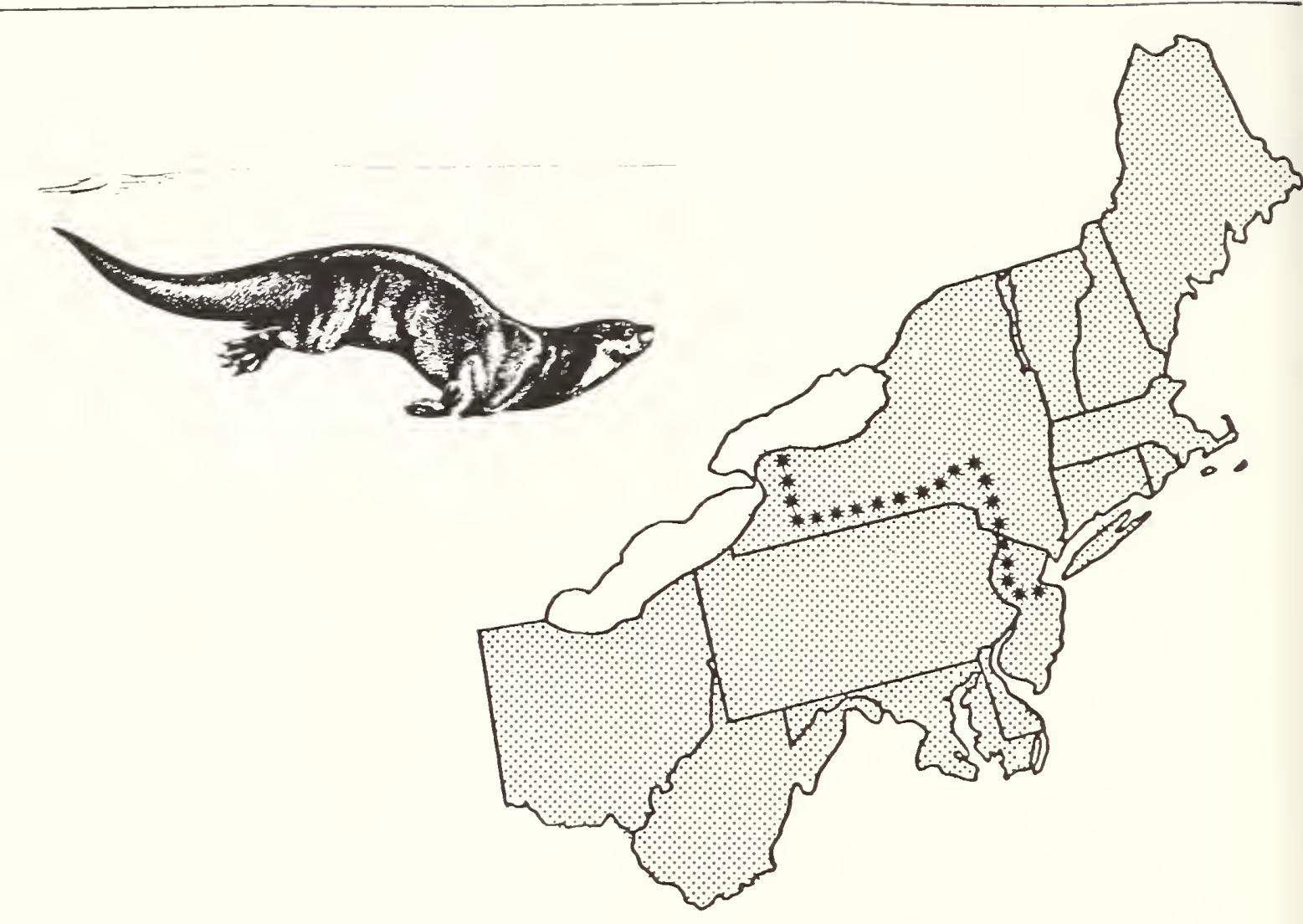

Range: Throughout all but northernmost portions of Canada and Alaska and in all states of the U.S. Does not occur in deserts or treeless regions.

Relative abundance in the Northeast: Uncommon, but probably more common than sightings and trapping would indicate.

Habitat in the Northeast: Borders of streams, lakes or other wetlands in forested areas.

Special habitat requirements: Body of water such as stream, pond, lake, river; suitable den sites.

Reproduction

Age at sexual maturity: Possibly 2 years (Hamilton and Eadie 1964) Breeding period: March or Apri1, followed by a 10 or 11 month delayed implantation

Gestation period: 9 to 12 months (Hamilton and Eadie 1964)

Young born: March or Apri1

Litter size: 1 to 5 , average 2 or 3

No. litters/year: 1 
Home range: 15 or more linear miles $(24 \mathrm{~km})$ (Burt and Grossenheider 1976), 20 or 30 linear miles ( 32 or $48 \mathrm{~km}$ ) for a pair or male but usually less than 1 mile $(1.6 \mathrm{~km})$ for females with young (Jackson 1961:384).

Food habits: Aquatic animals especially fish, frogs, crayfish, salamanders and turtles. Also takes snakes, small birds and earthworms.

Economic status: Furbearer

Comments: Mainiy nocturnal and active throughout the year. Den may be in crevice in rocky ledge, under fallen tree, in abandoned beaver lodge or muskrat house or in dense thickets bordering water. This species may be more common than sightings and pelts taken would indicate.

Key natural history references: Jackson 1961, Liers 1961, Hamilton and Eadie 1964. 
Range: Southern Canada south in the western mountains of the United States to South America, with remnant populations in Florida and possibly New Brunswick.

Relative abundance in the Northeast: Extirpated. No breeding population.

Habitat in the Northeast: Historically used a variety of habitat. If stragglers are present today, they probably inhabit remote mountain forests, swamps and wooded watercourses.

Special habitat requirements: Isolation from man. Requires abundant supply of deer for prey.

\section{Reproduction}

Age at sexual maturity: 2 or 3 years

Breeding period: Throughout the year (every 2 or 3 years) Gestation period: 3 months

Young born: Throughout the year (spring-born cubs have highest survival rates in the North)

Litter size: 1 to 5 , typically 2 or 3

Home range: May range 20 or 301 inear miles (32 to $48 \mathrm{~km}$ ) during hunting trips (Hamilton and Whitaker 1979:310). Home ranges in the Northeast are not known. Western home ranges may exceed $30 \mathrm{mi}^{2}\left(78 \mathrm{~km}^{2}\right)$ (Wright 1973).

Food habits: Nocturnal. Feeds on deer, foxes, beavers, porcupine, raccoons, skunks, rabbits and smaller mammals. Caches large prey.

Economic status: Protected in the Northeast.

Comments: There is little if any evidence of a breeding population in the northeastern U.S. A sparse population may exist in the southeastern states although evidence is not clear. There is a small population in Florida (Rainer Brocke, pers. comm.). Sightings in the Northeast have not been confirmed. Stragglers, if present, are probably escapees from zoos or people illegally keeping them as pets.

Key natural history references: Young and Goldman 1946, Hamilton and Whitaker 1979. 


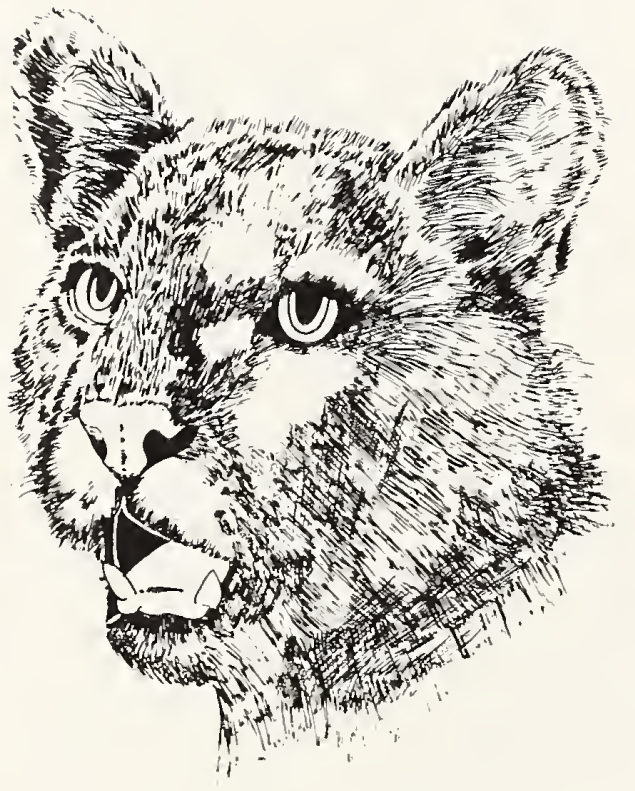




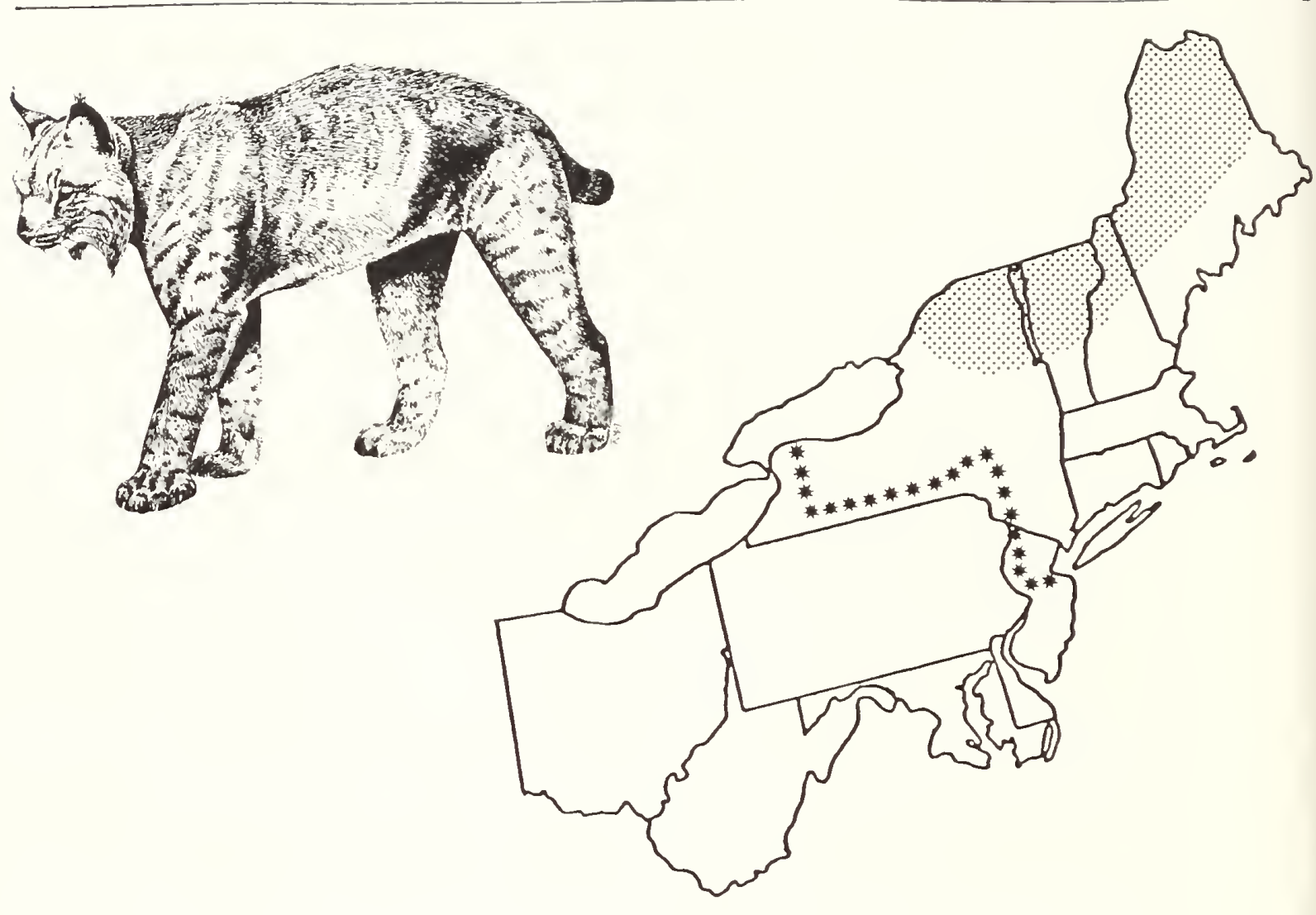

Range: Newfoundland west to Yukon Territory and Alaska south in the U.S. to northern Oregon, northern Wiscons in and northern New England.

Relative abundance in the Northeast: Uncommon to rare

Habitat in the Northeast: Interiors of extensive, unbroken forests we11 removed from man. Favors swamps or rocky areas.

Special habitat requirements: Secluded den sites, extensive forests. Reproduction

Age at sexual maturity: 1 year

Breeding period: January to February

Gestation period: About 62 days

Young born: March to April

Litter size: 1 to 4

No. litters/year: 1

Home range: About $5 \mathrm{mi}^{2}\left(13 \mathrm{~km}^{2}\right.$ ) during breeding season (Burt and Grossenheider 1976). 6 to $8 \mathrm{mi}^{2}\left(16\right.$ to $21 \mathrm{~km}^{2}$ ) with 2.6 mile $(4.2 \mathrm{~km}$ ) daily cruising radius (Banfield 1974:350). 
Food habits: Mainly snowshoe hares (staple), rodents and birds. Occasionally carrion of deer or caribou. Lynx populations fluctuate with snowshoe hare abundance reaching peak numbers about once every ten years.

Economic status: Forbearer

Comments: Mainly nocturnal and solitary; active throughout the year. Rears young in den which may be among rocks, under fallen tree, in a hollow log or other sheltered place.

Key natural history references: Saunders 1963a and 1963b, Siegler 1971, Banfield 1974, God in 1977.

149 


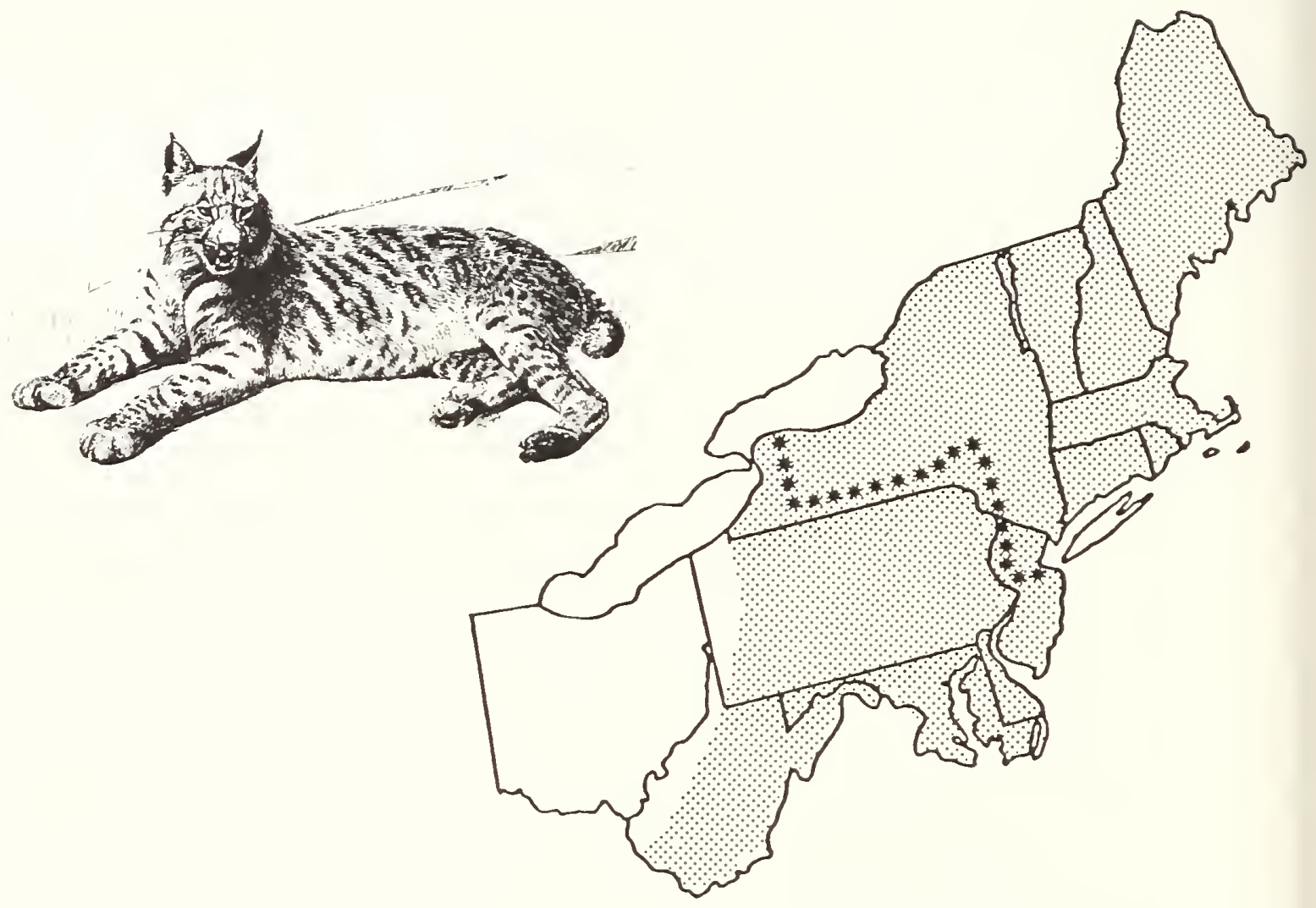

Range: Southern Canada south throughout the western half of the U.S. and through the eastern uplands and mountains. Also occurs along the Gulf Coast and in Florida.

Relative abundance in the Northeast: Common to uncommon

Habitat in the Northeast: Mixed deciduous-coniferous and hardwood forests and brushy and rocky woodlands broken by fields, old roads and farmland. Frequently found in cedar swamps and spruce thickets. Favors areas with thick undergrowth.

Special habitat requirements: Prefers to den in rock crevices, under windfalls or in hollow logs. The den is usually lined with dried grasses, leaves and moss.

Reproduction

Age at sexual maturity: Females mature within a year after birth. Males mature during second year (Crowe 1975)

Breeding period: Late February to March, sometimes extending into June

Gestation period: About 62 days

Young born: Late April to mid-May

Litter size: 1 to 4 kittens, average 2

No. litters/year: Second litter sometimes born in early August. May be regularly polyestrus in the southern portion of the range (Banfield 1974:353) 
Home range: 2 to 5 linear miles $(3.2$ to $8 \mathrm{~km}$ ) for nightly travel in Massachusetts (Pollack 1951). Ranges farther to find mates or follow prey. In Minnesota bobcats traveled 3 to 7 miles (4.8 to $11.2 \mathrm{~km}$ ) while hunting (Rollings 1945).

Food habits: Small mammals, especially snowshoe hares, cottontails, squirrels, mice, birds and their eggs. Carrion (untainted), snakes, fish, crustaceans, insects and some vegetation are also eaten. Most prey is taken by stalking.

Economic status: Furbearer, protected in some areas.

Comments: Favors established routes and uses scent posts. Solitary and elusive, mainly nocturnal but in winter is active during daylight. Avoids crossing bodies of water but can swim well (Godin 1977:241).

Key natural history references: Rollings 1945, Siegler 1971, Banfield 1974, McCord 1974, Godin 1977. 


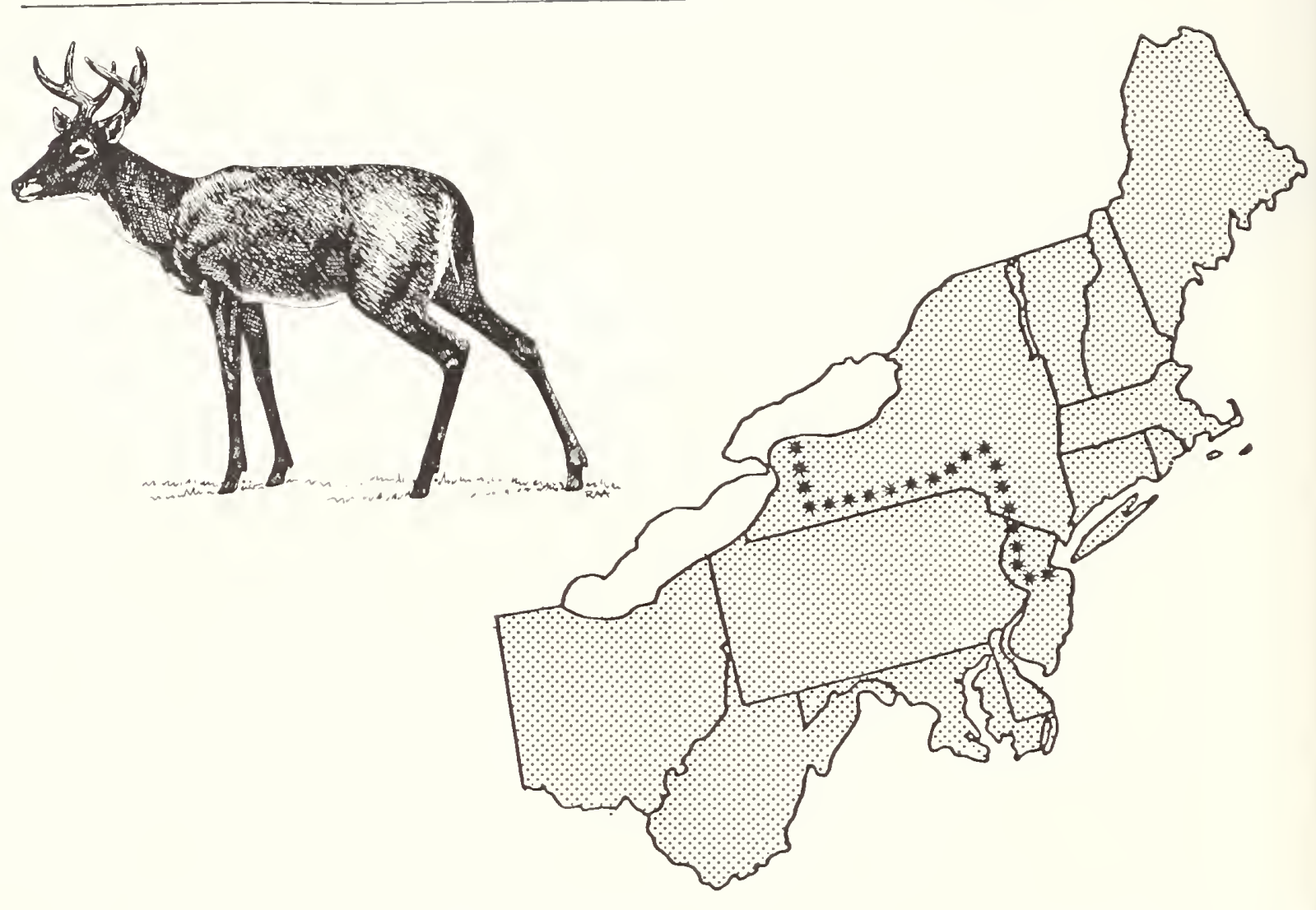

Range: Across southern Canada to central British Columbia and throughout the U.S., except for most of California, Nevada, Utah and western Colorado. Range extends into South America.

Relative abundance in the Northeast: Common

Habitat in the Northeast: Forest edges, swamp borders, areas interspersed with fields and woodland openings. During winter months when snow depth exceeds 16 inches $(40.6 \mathrm{~cm})$ deer wi1l "yard" in stands of conifers, forming a central resting area with trails packed through the snow.

Special habitat requirements: Dense cover, adequate browse.

\section{Reproduction}

Age at sexual maturity: Some females mate as yearlings, most males and females are mature at 18 months.

Breeding period: Late October to mid-December

Peak: November

Gestation period: 201 days

Young born: May and June with an extreme spread from March to September

Litter size: 1 to 4 fawns, average 2 
Home range: 2 to $3 \mathrm{mi}^{2}$ (5.2 to $7.8 \mathrm{~km}^{2}$ ) (Godin 1977). Size depends on the quality of the habitat. Home range may vary from 40 acres (16.2 ha) in excellent habitat to 300 acres (121.5 ha) in poor habitat (Banfield 1974:392).

Food habits: Mainly crepuscular. Deer browse on a variety of woody deciduous plants and some coniferous growth, feeding on twigs and stripping young bark. Also graze on grasses, herbs and mushrooms and grub for roots.

Economic status: Game

Comments: Gregarious, usually forming small groups. Family groups consisting of doe with her fawns and yearlings are common in the late fall.

Key natural history references: Taylor 1956, Banfield 1974, Godin 1977. 

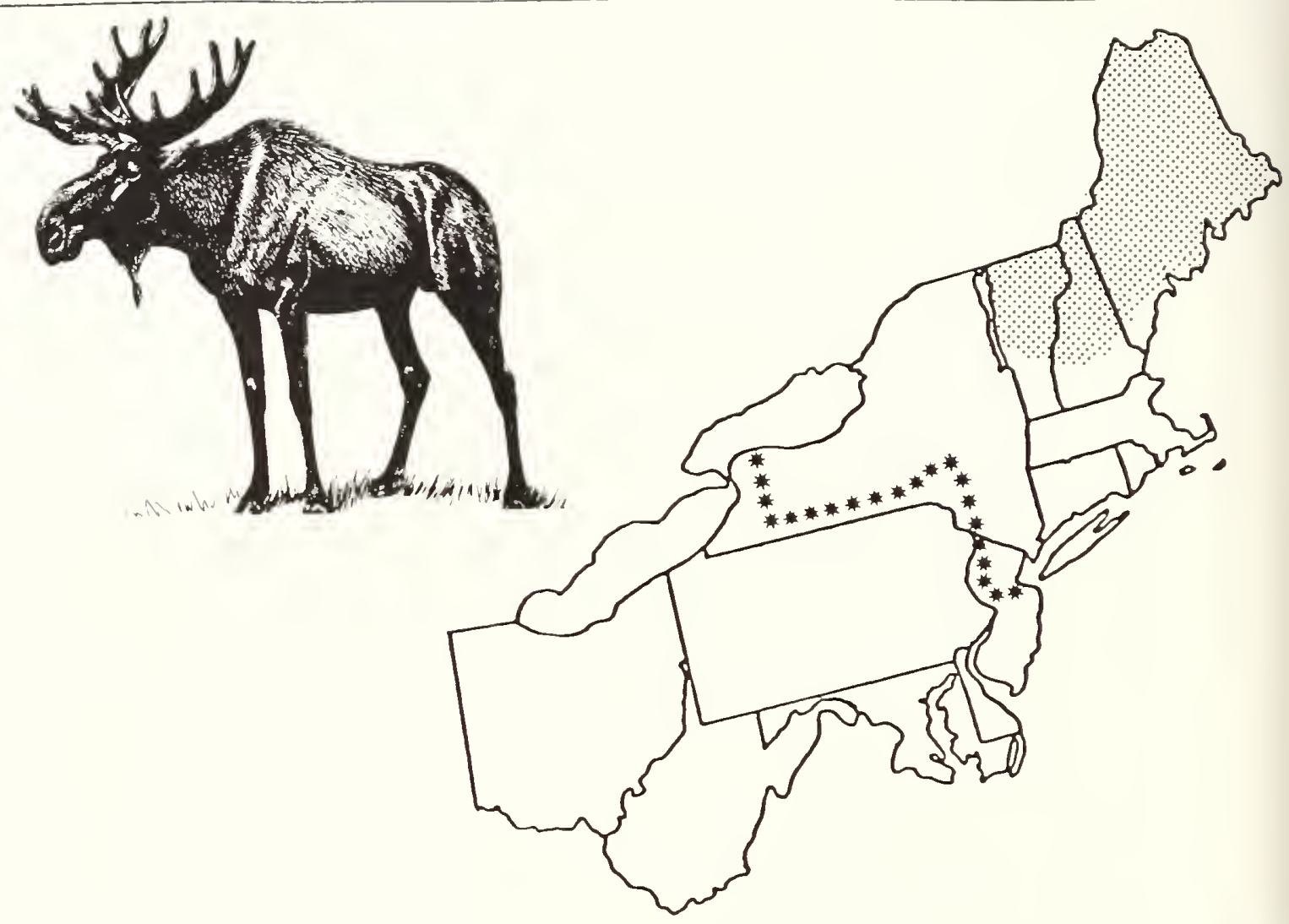

Range: Alaska, the southern half of Canada, northern New England and the northern Rockies into Utah.

Relative abundance in the Northeast: Locally common to uncommon Habitat in the Northeast: Second-growth forests interspersed with semi-open areas and swamps or lakes that offer cover and aquatic plants for food. Summers are spent near water; winters in drier mixed hardwood-conifer forests.

Special habitat requirements: Wetlands preferred in summer for relief from mosquitos and $f 1$ ies and for aquatic plant food items.

Reproduction

Age at sexual maturity: Some females may mature at 16 months and produce young in their second year (Peterson 1955:99). Most males probably mature at $1-1 / 2$ years but are unable to breed until 5 or 6 years old due to competition from older bulls.

Breeding period: Early September to late October

Peak: Mid-September

Gestation period: 240-246 days 
Young born: Late May to early June

Litter size: 1, rarely 2; average approximately 1.2

Home range: Probably a radius of 2 to 10 miles $(3.2$ to $16 \mathrm{~km}$ ) if adequate year-round food supply is available (Peterson 1955:113). Bul1s wi11 range farther during breeding season.

Sample density: In eastern North America, the average density is 1 moose $/ 5 \mathrm{mi}^{2}\left(13 \mathrm{~km}^{2}\right)$ over much of its range. 2 or more moose $/ \mathrm{mi}^{2}\left(0.8 / \mathrm{km}^{2}\right)$ approaches carrying capacity (Peterson 1955:202).

Food habits: During summer they prefer to feed in or near clearings, burns or shoreline areas where they browse on tender leaves, twigs and bark of deciduous trees and semi-aquatic and aquatic vegetation. They also graze on grasses, lichens, mosses, mushrooms and herbaceous plants. Winter diet is restricted to conifer (especially balsam fir) and hardwood twigs.

Economic status: Game

Comments: Populations are increasing in Maine and northern New Hampshire. Moose in mountainous regions generally seek lower elevations in autumn (Edwards and Ritcey 1956). They may gather together in yards during winter and congregate in $1 i 1 y$ ponds during summer months but are mainly solitary animals. They are most active at dawn and dusk.

Key natural history references: Murie 1934, Peterson 1955, Banfield 1974, Godin 1977. 


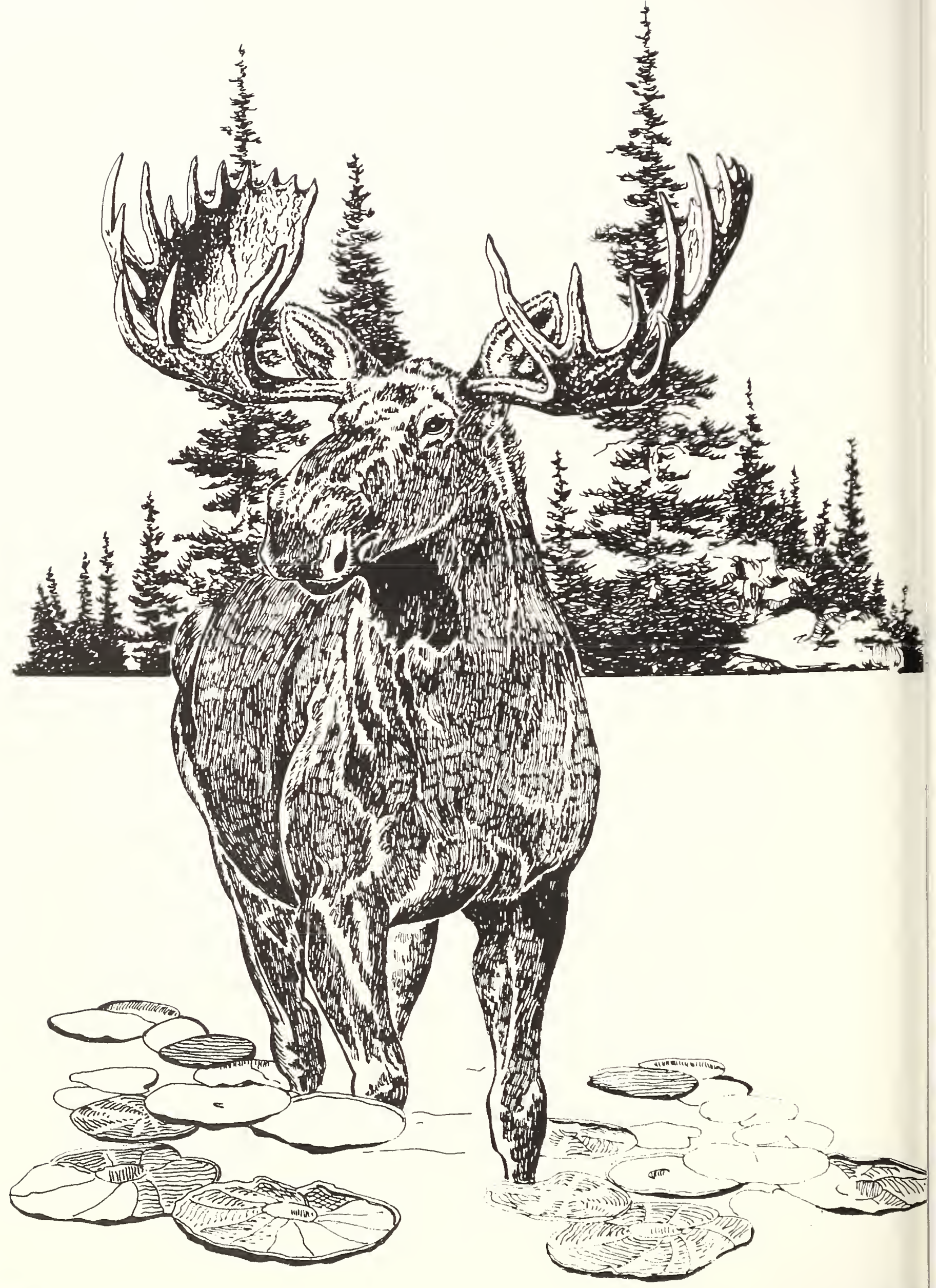




\section{REFERENCES}

Ables, E. D.

1969. Home range studies of red foxes Vuzpes vulpes. J. Mamm. 50 ( 1 ) : 108-120.

Adams, L.

1959. An analysis of a population of snowshoe hares in northwestern Montana. Ecol. Monogr. 29(2):141-170.

Aldous, C. M.

1937. Notes on the life history of the snowshoe hare. J. Mamm. $18(1): 46-57$.

Allen, E. G.

1938. The habits and life history of the eastern chipmunk (Tamias striatus Zysteri). New York State Mus. Bu11. 314:1-122.

Allen, J. M.

1954. Gray and fox squirrel management in Indiana. Indiana Dept. of Conserv. Pittman-Robertson Bu11. 1:1-112.

Anthony, E. L. and T. H. Kunz.

1977. Feeding strategies of the 1ittle brown bat, Myotis Lucifugus, in southern New Hampshire. Ecology 58(4):775-786.

Arlton, A. V.

1936. An ecological study of the common mole. J. Mamm. 17:349-371.

Bailey, $V$.

1924. Breeding, feeding, and other life habits of meadow mice Microtus. J. Agric. Res. 27(8):523-536.

Banfield, A. W. F.

1974. The mammals of Canada. Univ. of Toronto Press, Toronto. $438 \mathrm{p}$.

Barbour, R. W. and W. H. Davis.

1969. Bats of America. Univ. of Kentucky Press, Lexington. 286 p. 
Barbour, R. W. and W. H. Davis.

1974. Mammals of Kentucky. Univ. of Kentucky Press, Lexington. $322 \mathrm{p}$.

Bekoff, $M$.

1977. Canis Zatrans. Amer. Soc. Mammalogists. Mammalian Species No. 79:1-9.

Bekoff, M. (editor).

1978. Coyotes: biology, behavior and management. Academic Press, New York. 384 p.

Benton, A. H.

1955. Observations on the life history of the northern pine mouse.

J. Mamm. 36(1):52-62.

Berg, W. E. and R. A. Chesness.

1978. Ecology of coyotes in northern Minnesota. Pg. 229-247 In Coyotes: biology, behavior and management. (M. Bekoff, ed.), Academic Press, New York. 384 p.

Beule, J. D. and A. T. Studholme.

1942. Cottontail rabbit nests and nestlings. J. Wild1. Mgmt. $6(2): 133-140$.

Bider, J. R.

1961. An ecological study of the hare (Lepus americanus). Canadian J. Zoo1. 39(1):81-103.

Bishop, S. C.

1947. Curious behavior of a hoary bat. J. Mamm. 28(3):293-294.

Blair, W. F.

1940a. Notes on home ranges and populations of the short-tailed shrew. Ecology 21(2):284-288.

1940b. Home ranges and populations of the meadow vole in southern

Michigan. J. Wild1. Mamt. 4:149-161.

1940c. Home ranges and populations of the jumping mouse. Amer.

Midland Nat. 23(1):244-250. 
Blair, W. F.

1941. Some data on the home ranges and general life history of the short-tailed shrew, red-backed mouse and woodland jumping mouse in northern Michigan. Amer. Midland Nat. 25(3):681-685.

1942. Size of home range and notes on the life history of the woodland deer mouse and eastern chipmunk in northern Michigan. J. Mamm. 23(1):27-36.

Bogan, M. A.

1972. Observations on parurition and development in the hoary bat (Lasiurus cinereus). J. Mamm. 53(3):611-614.

Bronson, F. H. and 0. W. Tiemeier.

1958. Reproduction and age distribution of the black-tailed jackrabbit in Kansas. J. Wild1. Mgmt. 22(4):409-414.

Brower, J. E. and T. J. Cade.

1966. Ecology and physiology of Napaeozapus insignis Miller and other woodland mice. Ecology 47(1):46-63.

Buckner, C. H.

1957. Home range of Synaptomys cooperi. J. Mamm. 38(1):132.

Buckner, C. H. and D. G. H. Ray.

1968. Notes on the water shrew in bog habitats of southeastern Manitoba. Blue Jay 26(2):95-96.

Burt, W. H.

1940. Territorial behavior and populations of some small mammals in southern Michigan. Univ. of Michigan Mus. Zool. Misc. Publ. 45:1-58.

1948. Mammals of Michigan. Univ. of Michigan Press, Ann Arbor. 288 p.

1957. Mamma1s of the Great Lakes Region. Univ. of Michigan Press, Ann Arbor. 246 p. 
Burt, W. H. and R. P. Grossenheider.

1976. A field guide to the mammals. (Third edition). Houghton Mifflin Co., Boston. $289 \mathrm{p}$.

Cagle, F. R. and L. Cockrum.

1943. Notes on a summer colony of Myotis Zucifugus Zucifugus.

J. Mamm. 24(4):474-492.

Cahalane, V. H.

1947. Mammals of North America. Macmillan Co., New York. 682 p.

Calhoun, J. B.

1962. The ecology and sociology of the Norway rat. U.S. Dept.

Health, Educ. and Welfare. Public Health Service Pub1. 1008:1-288.

Cameron, A. W.

1958. Mammals of the islands in the Gulf of St. Lawrence. Nat.

Mus. Canada Bu11. No. 154. 165 p.

Cardoza, J.

1976. The history and status of the black bear in Massachusetts and adjacent New England states. Mass. Div. of Fish and Wildl. Research Bu11. No 18. 113 p.

Chapman, J. A., A. L. Harman and D. E. Samue1.

1977. Reproductive and physiological cycles in the cottontai1 complex in western Maryland and nearby West Virginia. Wildl. Monogr. No. 56. 73 p.

Choate, J. R.

1973. Identification and recent distribution of white-footed mice (Peromyscus) in New England. J. Mamm. 54(1):41-49.

Cockrum, E. L.

1952. Mammals of Kansas. Univ. of Kansas Publ., Mus. Nat. Hist. $7: 1-303$. 
Conaway, C. H.

1952. Life history of the water shrew (Sorex palustris navigator). Amer. Midland Nat. 48(1):219-248.

1958. Maintenance, reproduction and growth of the least shrew in captivity. J. Mamm. 39(4):507-512.

Conaway, C. H. and D. W. Pfitzer.

1952. Sorex palustris and Sorex dispar from the Great Smoky Mountains

National Park. J. Mamm. 33(1):106-108.

Connor, P. F.

1959. The bog 1emming Synaptomys cooperi in southern New Jersey.

Pub1. Mus. Michigan State Univ. Biol. Ser. 1:161-248.

1960. The smal1 mammals of Otsego and Schoharie Counties, New York.

New York State Mus. Sci. Serv. Bu11. 382:1-84.

1971. The mamma Is of Long Island, New York. New York State Mus.

and Sci. Serv. Bu11. 416:1-78.

Constantine, D. G.

1966. Ecological observations on lasiurine bats in Iowa. J. Mamm. $47(1): 34-41$.

Coste110, D. F.

1966. The world of the porcupine. J. B. Lippincott Co., Philadelphia.

Coulter, M. W.

1966. Ecology and management of fishers in Maine. Ph.D. diss.

Syracuse Univ., Syracuse, New York.

Cowan, I. McT.

1936. Nesting habits of the flying squirrel (GLaucomys sabrinus).

J. Mamm. 17(1):58-60.

Cowan, I. MCT. and C. J. Guiguet.

1965. The mammals of British Columbia. British Columbia Provincial Mus. Pub1. No. 11:1-141. 
Criddle, S.

1932. The red-backed vole (Clethrionomys gapperi Zoringi Bailey) in southern Manitoba. Canadian Field Nat. 46(8):178-181.

Crowe, D. M.

1975. Aspects of aging, growth and reproduction of bobcats in Wyoming. J. Mamm. 56(1):177-198.

Curtis, J. D. and E. L. Kozicky.

1944. Observations on the eastern porcupine. J. Mamm. 25(2):137-146.

Dalke, P. D.

1942. The cottontail rabbits in Connecticut. Conn. Geol. and Nat. Hist. Surv. Bull. No. 65. 97 p.

Dalke, P. D. and P. R. Sime.

1938. Home and seasonal ranges of the eastern cottontail in Connecticut. Trans. N. Amer. Wildl. Conf. 3:659-669.

Davis, D. E.

1953. The characteristics of rat populations. Quart. Rev. Biol. $28(4): 373-401$.

Davis, W. H. and H. B. Hitchcock.

1965. Biology and migration of the bat, Myotis Zucifugus, in New England. J. Mamm. 46(2):296-313.

Davis, W. H. and R. E. Mumford.

1962. Ecological notes on the bat (Pipistrelzus subflavus). Amer. Midland Nat. 68(2):394-398.

Dean, P. B. and A. deVos.

1965. The spread and present status of the European hare (Lepus europaeus hybridus) in North America. Canadian Field Nat. $79(1): 38-48$.

Dodds, D. G.

1965. Reproduction and productivity of snowshoe hares in Newfoundland. J. Wild1. Mgmt. 29(2):303-315. 
Dodge, W. E.

1967. The biology and life history of the porcupine, Erethizon dorsatum, in western Massachusetts. Ph.D. diss. Univ. of Massachusetts, Amherst.

Doebel, J. and B. McGinnes.

1974. Home range and activity of a gray squirrel population. J. Wild1. Mgmt. 38(4):860-867.

Dolan, P. G. and D. C. Carter.

1977. Glaucomys volans. Amer. Soc. Mammalogists. Mammalian Species, No. 78:1-6.

Druecker, J. D.

1972. Aspects of reproduction in Myotis volans, Lasionycteris noctivagans and Lasiums cinereus. Diss. Abstr. Int., $33 B(10): 5065$.

Eabry, H. S.

1970. A feasibility study to investigate and evaluate the possible directions of European hare management in New York. Federal Aid Pittman-Robertson Project W-84-R17.

Eadie, W. R.

1939. A contribution to the biology of Parascalops breweri.

J. Mamm. 20(2):150-173.

Eadie, W. R. and W. J. Hamilton, Jr.

1956. Notes on reproduction in the star-nosed mole. J. Mamm. $37(2): 223-231$.

Edwards, R. Y. and R. W. Ritcey.

1956. The migrations of a moose herd. J. Mamm. 37(4):486-494.

E11iott, L.

1978. Social behavior and foraging ecology of the eastern chipmunk (Tomias striatus) in the Adirondack Mountains. Smithsonian Contrib. to Zoo1. No. 265. 107 p. 
Elton, C. and M. Nicholson.

1942. Fluctuations in numbers of muskrat (Ondatra zibethica) in Canada. J. Animal Ecol. 11(1):96-126.

Enders, R. K.

1952. Reproduction in the mink. Proc. Amer. Philo. Soc. 96(6):691-755.

Errington, P. L.

1961. Muskrats and marsh management. Wildl. Mgmt. Inst., Univ. of Nebraska Press, Lincoln. 183 p.

1963. Muskrat populations. Iowa State Univ. Press, Ames, Iowa. $655 \mathrm{p}$.

Errington, P. L. and C. S. Errington.

1937. Experimental tagging of young muskrats for purposes of study. J. Wild1. Mgmt. 1(3-4):49-61.

Fall, M. W.

1971. Seasonal variations in the food consumption of woodchucks, Marmota monax. J. Mamm. 52(2):370-375.

Faulkner, C. E. and W. E. Dodge.

1962. Control of the porcupine in New England. New Hampshire's Conserv. Mag. 72:9-10, 18.

Fay, F. H. and E. H. Chandler.

1955. The geographical and ecological distribution of cottontail rabbits in Massachusetts. J. Mamm. 36(3):415-424.

Fitch, J. H. and K. A. Shump, Jr.

1979. Myotis keenii. Amer. Soc. Mammalogists. Mammalian Species No. $121: 1-3$.

Flyger, V. F.

1960. Movements and home ranges of the gray squirrel (Sciums carolinensis) in two Maryland woodlots. Ecology 41(2):365-369. 
Forbes, R. B.

1966. Studies of the biology of Minnesotan chipmunks. Amer. Midland Nat. 76:290-308.

Francq, E. N.

1969. Behavioral aspects of feigned death in the opossum (Didelphis marsupialis). Amer. Midland Nat. 81(2):556-568.

French, N. R.

1964. Analysis of reproduction in a black-tailed jackrabbit population. Proc. 16th Intern. Congr. Zoo1. 1:258.

French, N. R., R. McBride and J. Detmer.

1965. Fertility and population densities of the black-tailed jackrabbit. J. Wi1d1. Mgmt. 29(1):14-26.

Getz, L. L.

1961a. Factors influencing the local distribution of shrews. Amer. Midland Nat. 65:67-88.

1961b. Home ranges, territoriality and movement of the meadow vole. J. Mamm. 42(1):24-36.

Godin, A. J.

1977. Wild mammals of New England. Johns Hopkins Univ. Press, Baltimore. $304 \mathrm{p}$.

Goertz, J. W.

1970. An ecological study of Neotoma floridana in Oklahoma.

J. Mamm. 51(1):94-104.

Goodwin, G. G.

1935. The mammals of Connecticut. Conn. Geol. and Nat. Hist. Surv. Bu11. 53:1-221.

Griffin, D. R.

1940a. Migrations of New England bats. Harvard Univ. Mus. Compar. Zoo1. Bu11. 86:217-246. 
Griffin, D. R.

1940b. Notes on the life histories of New England cave bats.

J. Mamm. $21(2): 181-187$.

1945. Travels of banded cave bats. J. Mamm. 26(1):15-23.

Grizzel1, R. A., Jr.

1955. A study of the southern woodchuck, Marmota monax monax.

Amer. Midland Nat. 53(2):257-293.

Hal1, E. R.

1951. Mustela erminea. In American weasels. Univ. Kansas Publ., Mus. Nat. Hist. 4:87-167.

Hal1, J. S.

1956. Life history studies of the eastern pipistrel bat (Pipistrezzus subflavus) in Massachusetts. M.A. thesis, Univ. of Massachusetts, Amherst. $74 \mathrm{p}$.

1960. A life history and taxonomic study of Indiana bat, Myotis sodalis. Ph.D. diss., Univ. of Illinois. $135 \mathrm{p}$.

1962. A life history and taxonomic study of the Indiana bat, Myotis sodalis. Scientific Publ. No. 12. Reading, Pa. Public Mus. and Art Gallery. 68 p.

Hallett, J. G.

1978. Parascalops breweri. Amer. Soc. Mammalogists. Mammalian

Species No. 98:1-4.

Hamilton, W. J., Jr.

1931a. Habits of the short-tailed shrew (BZarina brevicauda Say).

Ohio J. Sci. 31(2):97-106.

1931b. Habits of the star-nosed mole (CondyZura cristata). J. Mamm.

$12(4): 345-355$.

1933a. The insect food of the big brown bat. J. Mamm. 14(2):155-156. 1933b. The weasels of New York: Their natural history and economic

status. Amer. Midland Nat. 14(4):289-344.

1935. Habits of jumping mice. Amer. Midland Nat. 16(1):187-200. 
Hamilton W. J., Jr.

1936. The food and breeding habits of the raccoon. Ohio J. Sci. 36:131-140.

1937. Activity and home range of the field mouse, Microtus pennsyzvanicus pennsyzvanicus Ord. Ecology 18(2):255-263. 1938. Life history notes on the northern pine mouse. J. Mamm. 19(2):163-170.

1939a. Activity of Brewer's mole (Parascolops breweri). J. Mamm. 20(3):307-310.

1939b. Observations on the life history of the red squirrel in

New York. Amer. Midland Nat. 22(3):732-745.

1940. The biology of the smoky shrew (Sorex fumeus fumeus Miller).

Zoologica 25(4):473-492.

1941. Reproduction of the field mouse (Microtus pennsylvanicus Ord).

Corne11 Univ. Agric. Exp. Sta. Mem. 237:1-23.

1944. The biology of the little short-tailed shrew (Cryptotis parva).

J. Mamm. 25(1):1-7.

1958. Life history and economic relations of the opossum (Didelphis marsupialis viginiana) in New York State. Cornell Univ. Agric.

Exp. Sta. Mem. 354:1-48.

Hamilton, W. J., Jr. and W. R. Eadie.

1964. Reproduction in the otter (Lutra canadensis). J. Mamm. $45(2): 242-252$.

Hamilton, W. J., Jr. and J. O. Whitaker, Jr.

1979. Mammals of the eastern United States. Cornell Univ. Press, Ithaca, New York. $346 \mathrm{p}$.

Hartman, C. G.

1953. Breeding habits, development and birth of the opossum.

Smithsonian Report for 1921. p. 347-363.

Harvey, M. J.

1967. Home range, movements and diet activity of the eastern mole (Scalopus aquaticus). Ph.D. diss., Univ. of Kentucky. 78 p. 
Haske11, H. S. and H. G. Reynolds.

1947. Growth, development, food requirements and breeding activity of the California jackrabbit. J. Mamm. 28(2):129-136.

Hatt, R. T.

1929. The red squirrel: Its life history and habits. Bu11. New York College Forestry. Roosevelt Wild Life Annals 2(1):1-140.

Haugen, A. 0 .

1942. Life history studies of the cottontail rabbit in southwestern

Michigan. Amer. Midland Nat. 28(1):204-244.

Hilton, H.

1978. Systematics and ecology of the eastern coyote. P. 209-228.

In Coyotes: Biology, behavior and management. (M. Bekoff, ed.). Academic Press, New York. 384 p.

Hiner, L. E.

1938. Observations on the foraging habits of beavers. J. Mamm. $19(3): 317-319$.

Hitchcock, H. B.

1949. Hibernation of bats in southeastern Ontario and adjacent

Quebec. Canadian Field Nat. 63(2):47-59.

1955. A summer colony of the least bat, Myotis subulatus Leibii

(Audubon and Bachman). Canadian Field Nat. 69(2):31.

Hodgdon, H. E. and J. S. Larson.

1973. Some sexual differences in behavior within a study of marked

beavers (Castor canadensis). Animal Behavior 21(1):147-152.

Huey, W. C.

1956. New Mexico beaver management. New Mexico Dept. Game and

Fish Bul1. 4:1-49.

Humphrey, S. R.

1978. Status, winter habitat and management of the endangered Indiana bat, Myotis sodalis. Florida Sci. 41(2):65-76. 
Humphrey, S. R. and J. B. Cope.

1976. Population ecology of the little brown bat, Myotis Iucifugus, in Indiana and north-central Kentucky. Amer. Soc. Mammalogists. Special Publ. No. 4. $81 \mathrm{p}$.

Humphrey, S. R., A. R. Richta and J. B. Cope.

1977. Summer habitat and ecology of the endangered Indiana bat, Myotis sodalis. J. Mamm. 58(3):334-346.

Ickes, R. A.

1974. Agonistic behavior and the use of space in the eastern chipmunk, Tamias striatus. Ph.D. diss., Univ. of Pittsburgh.

Jackson, H. H. T.

1961. Mammals of Wisconsin. Univ. of Wisconsin Press, Madison. $504 \mathrm{p}$.

Jameson, E. W., Jr.

1949. Some factors influencing the local distribution and abundance of woodland small mammals in central New York. J. Mamm. 30:221-235.

Jenkins, S. H. and P. E. Busher.

1979. Castor canadensis. Amer. Soc. Mammalogists. Mammalian Species No. 120:1-8.

Johnson, C. E.

1925. The muskrat in New York: Its natural history and economics. Roosevelt Wild Life Bul1. 3:199-320.

Johnston, J. E.

1972. Identification and distribution of cottontail rabbits in southern New England. M.S. thesis, Univ. of Connecticut.

Jones, H. W., Jr.

1939. Winter studies of skunks in Pennsylvania. J. Mamm. $20(2): 254-256$. 
Jonkel, C. J. and I. MCT. Cowan.

1971. The black bear in the spruce-fir forest. Wild1. Monogr. No. $27.57 \mathrm{p}$.

Jordan, J.S.

1948. A midsummer study of the southern flying squirrel. J. Mamm. $29(1): 44-48$.

Kel1y, G. M.

1977. Fisher (Martes pennanti). Biology in the White Mountains

National Forest and adjacent areas. Ph.D. diss., Univ. of Massachusetts, Amherst.

King, J. A. (editor).

1968. Biology of Peromyscus (Rodentia). Amer. Soc. Mammalogists. Special Pub1. No. 2. 593 p.

Kirkland, G. L., Jr.

1977a. The rock vole, Microtus chrotorshinus Miller (Mammalia:

Rodentia), in West Virginia. Annals Carnegie Mus.

No. $46(5): 45-53$.

1977b. Responses of smal1 mammals to the clearcutting of northern Appalachian forests. J. Mamm. 58(4):600-609.

1978. Initial responses of small mammals to clearcutting of Pennsylvania hardwood forests. Proc. Pennsylvania Acad. Sci. $52(1): 21-23$.

Kirkland, G. L., Jr., C. R. Schloyer and D. K. Hull.

1976. A novel habitat record for the long-tailed shrew, Sorex dispar Batchelder. Proc. West Virginia Acad. Sci. 48.

Nos. 2, 3, 4:77-79.

Kirkland, G. L., Jr. and C. M. Knipe.

1979. The rock vole (Microtus chrotorrhinus) as a transition zone species. Canadian Field Nat. 93(3):319-321. 
Kirkland, G. L., Jr. and H. M. Van Deusen.

1979. The shrews of the Sorex dispar group: Sorex dispar Batchelder and Sorex gaspensis Anthony and Goodwin. Amer. Mus. Novitates. No. 2675:1-21.

Klein, H. G.

1960. Ecological relationships of Peromyscus Zeucopus noveboracensis and $P$. maniculatus gracilis in central New York. Ecol. Monogr. 30(4):387-407.

Klugh, A. B.

1927. Ecology of the red squirre1. J. Mamm. 8(1):1-32.

Kunz, T. H.

1971. Reproduction of some vespertillionid bats in central Iowa. Amer. Midland Nat. 86:477-486.

1973. Resource utilization: temporal and spatial components of bat activity in central Iowa. J. Mamm. 54(1):14-32.

Larson, J. S.

1962. Notes on a recent squirrel emigration in New England.

J. Mamm. 43(2):272-273.

1967. Age structure and sexual maturity within a western Maryland beaver (Castor canadensis) population. J. Mamm. 48(3):408-413.

Lay, D. W.

1942. Ecology of the opossum in eastern Texas. J. Mamm. 23(2):147-159.

Layne, J. N.

1954. The biology of the red squirre1, Tomiasciums hudsonicus Zoquax Bangs, in central New York. Ecol. Monogr. 24(2):227-267. 1958. Notes on mammals in southern Illinois. Amer. Midland Nat. $60(1): 219-254$.

Layne, J. N. and W. J. Hamilton, Jr.

1954. The young of the woodland jumps in mouse, Napaeozapus insignis insignis Miller. Amer. Midland Nat. 52(1):242-247. 
Leftwich, B. H.

1972. Population dynamics and behavior of the eastern mole,

Scalopus aquaticus machrinoides. Univ. of Missouri, Columbia. 103 p. Diss. Abstr. Int. 34B(3):1324-5.

Lidicker, W. Z.

1966. Ecological observations on a feral house mouse population declining to extinction. Ecol. Monogr. 36(1):27-50.

Liers, E. E.

1951. Notes on the river otter (Iutra canadensis). J. Mamm. $32(1): 1-9$.

Llewellyn, L. M. and F. H. Dale.

1964. Notes on the ecology of the opossum in Maryland. J. Mamm. $45(1): 113-122$.

Long, C. A.

1972. Notes on habitat preference and reproduction in pygmy shrews (Microsorex). Canadian Field Nat. 86(2):155-160.

1974. Microsorex hoyi and Microsorex thompsoni. Amer. Soc.

Mammalogists. Mammalian Species No. 33:3-4.

Lotze, J. H. and S. Anderson.

1979. Procyon Zotor. Amer. Soc. Mammalogists. Mammalian Species No. 119:1-8.

Lovejoy, D. A.

1973. Ecology of the woodland jumping mouse (Napeozapus insignis) in New Hampshire. Canadian Field Nat. 87(2):145-149.

1975. The effect of logging on small mammal populations in New England northern hardwoods. Univ. Conn. Occasional Papers. Biol. Sci. Ser. 2(17):269-291.

Lynch, G. M.

1967. Long-range movement of a raccoon in Manitoba. J. Mamm. $48(4): 659-660$. 
McClure, H. E.

1942. Summer activities of bats (genus Lasiurus) in Iowa.

J. Mamm. 23(4):430-434.

McCord, C. M.

1974. Selection of winter habitat by bobcats (Lynx mufus) on the Quabbin Reservation, Massachusetts. J. Mamm. 55(2):428-437.

McDonough, J. J.

1960. The cottontail in Massachusetts. Mass. Div. of Fisheries and Game, Boston.

McKeever, S.

1952. The survey of West Virginia mammals. Conserv. Comm. West Virginia, Pittman-Robertson Project 22-TC. 126 p. mimeo.

McManus, J. L.

1971. Activity of captive Didelphis marsupialis. J. Mamm. $52(4): 846-848$.

1974. Didelphis viginiana. Amer. Soc. Mammalogists. Mammalian Species No. 40:1-6.

Madden, J.R.

1974. Female territoriality in a Suffolk County, Long Island population of Glaucomys volans. J. Mamm. 55:647-652.

Manville, R. H.

1949. A study of smal1 mammal populations in northern Michigan.

Univ. of Michigan, Misc. Pub1. Mus. Zoo1. 73:1-83.

Marsha11, W. H.

1951. Pine marten as a forest product. J. Forestry 49(12):899-905.

Marsha11, W. H., G. W. Gullion and R. G. Schwab.

1962. Early summer activities of porcupines as determined by radio-positioning techniques. J. Wild1. Mgmt. 26(1):75-79. 
Martin, R. L.

1971. The natural history and taxonomy of the rock vole, Microtus chrotorrhinus. Diss. Abstr. 32B:3079. Ph.D. diss., Univ. of Connecticut. $164 \mathrm{p}$.

Miller, D. H. and L. L. Getz.

1969. Life history notes on Microtus pinetomum in central Connecticut. J. Mamm. 50(4):777-784.

1972. Factors influencing the local distribution of the redback vole, Clethrionomys gapperi, in New England. Univ. Connecticut Occasional Papers. Biol. Sci. Ser. 2(9):115-138.

1973. Factors influencing the local distribution of the redback vole, Clethrionomys gapperi, in New England, II. Vegetation cover, soil moisture and debris cover. Univ. Connecticut Occasional Papers. Biol. Sci. Ser. 2(11):159-180.

Mil1s, R. S., G. W. Barrett and M. P. Farrel1.

1975. Population dynamics of the big brown bat (Eptesicus fuseus) in southwestern Ohio. J. Mamm. 56(3):591-604.

Mitche11, J. L.

1961. Mink movements and populations on a Montana river. J. Wild1.

Mgmt. 25(1):49-54.

Mock, 0. B.

1970. Reproduction of the least shrew (Cryptotis parva) in captivity. Ph.D. diss., Univ. of Missouri, Columbia.

Mohr, C. E.

1936. Notes on the least bats (Myotis subulatus leibii). Proc. Pennsylvania Acad. Sci. 10:62-65.

Murie, A.

1934. The moose of Isle Royale. Univ. of Michigan Mus. Zool. Misc. Pub1. 25:7-44. 
Muu 1, I.

1968. Behavioral and physiological influences on the distribution of the flying squirrel, Gzaucomys volans. Univ. of Michigan Mus. Zoo1. Misc. Pub1. 134:1-66.

Orr, R. T.

1950. Unusual behavior and occurrence of a hoary bat. J. Mamm. $31(4): 456-457$.

Ozoga, J. J. and E. M. Harger.

1966. Winter activities and feeding habits of northern Michigan coyotes. J. Wi 1d1. Mgmt. 30(4):809-818.

Pack, J., H. Mosby and P. Siegal.

1967. Influence of social hierarchy on gray squirrel behavior.

J. Wild1. Mgmt. $31(4): 720-728$.

Paradiso, J. L.

1969. Mammals of Maryland. N. Amer. Fauna Ser. No. 66. 193 p.

Pearson, P. G.

1952. Observations concerning the life history and ecology of the woodrat, Neotoma floridana floridana Ord. J. Mamm. 33(4):459-463.

Peterson, R. L.

1955. North American moose. Univ. of Tononto Press, Toronto. 280 p. 1966. The mammals of eastern Canada. Oxford Univ. Press, Toronto. $465 \mathrm{p}$.

Phillips, G. L.

1966. Ecology of the big brown bat (Chiroptera: Vespertilionidae) in northeastern Kansas. Amer. Midland Nat. 75(1):168-198.

Phillips, R. L., R. D. Andrews, G. L. Storm and R. A. Bishop. 1972. Dispersal and mortality of red foxes. J. Wild1. Mgmt. $36(2): 237-248$. 
Poole, E. L.

1940. A life history sketch of the Allegheny woodrat. J. Mamm. $21(3): 249-270$.

Pollack, E. M.

1951. Observations on New England bobcats. J. Mamm. 32(3):356-358.

Preble, N. A.

1956. Notes on the 1ife history of Napaeozapus. J. Mamm. 37(2):197-200.

Prince, L. A.

1941. Water traps capture the pygmy shrew (Microsorex hoyi) in abundance. Canadian Field Nat. 55(5):72.

Pringle, L. P.

1960. A study of the biology and ecology of the New England cottontail (SyIvizagus transitionaZis) in Massachusetts. M.S. thesis, Univ. of Massachusetts, Amherst.

Pruitt, W. 0., Jr.

1959. Microclimates and local distribution of small mammals on the George Reserve, Michigan. Univ. of Michigan Mus. Zool. Misc. Pub1. 109:1-27.

Quadagno, D. M.

1968. Home range size in feral house mice. J. Mamm. 49(1):149-151.

Quay, W. B.

1948. Notes on some bats from Nebraska and Wyoming. J. Mamm. $29(2): 181-182$.

Quick, H. F.

1944. Habits and economics of the New York weasel in Michigan. J. Wild1. Mgmt. 8(1):71-78.

Quimby, D. C.

1951. The life history and ecology of the jumping mouse, Zapus hudsonicus. Ecol. Monogr. 21(1):61-95. 
Rainey, D. G.

1956. Eastern wood rat, Neotoma floridana: Life history and ecology. Univ. of Kansas Mus. Nat. Hist. Pub1. 8:535-645.

Richens, V. B.

1974. Numbers and habitat affinities of smal1 mammals in northwestern Maine. Canadian Field Nat. 88(2):191-196.

Richmond, N. D. and W. C. Grimm.

1950. Ecology and distribution of the shrew, Sorex dispar, in Pennsylvania. Ecology 31(2):279-282.

Rollings, C. T.

1945. Habits, foods and parasites of the bobcat in Minnesota. J. Wild1. Mgmt. 9(2):131-145.

Ross, A.

1967. Ecological aspects of the food habits of insectivorus

bats. Proc. West. Found. Vertebr. Zoo1. 1(4):205-263.

Sargeant, A. B.

1972. Red fox spatial characteristics in relation to waterfow predation. J. Wild1. Mgmt. 36(2):225-236.

Saunders, J., Jr.

1963a. Food habits of the lynx in Newfoundland. J. Wildl. Mgmt. $27(3): 384-390$.

1963b. Movements and activities of the lynx in Newfoundland.

J. Wildl. Mgmt. 27(3):399-400.

Schwartz, C. W. and E. R. Schwartz.

1959. The wild mammals of Missouri. Univ. of Missouri Press, Columbia. $341 \mathrm{p}$.

Scott, T. G.

1943. Some food coactions of the northern plains red fox. Ecol. Monogr. 13(4):427-479. 
Seagears, $C$.

1944. The fox in New York. New York State Conserv. Dept., Albany. $85 \mathrm{p}$.

Seton, E. T.

1909. The hoary bat or great northern bat. In Life Histories of northern animals, 2:1191-1200. Scribner's Sons, New York.

1929. Lives of game animals. Doubleday, Doran and Co., Inc. Garden City, New York. 4 vols.

Shanks, C. E. and G. C. Arthur.

1952. Muskrat movements and population dynamics in Missouri ponds and streams. J. Wild1. Mgmt. 16(2):138-148.

Shapiro, J.

1949. Ecological and life history notes on the porcupine in the Adirondacks. J. Mamm. 39(3):247-257.

Sharp, W. M.

1960. A commentary on the behavior of free-ranging gray squirrels. Pennsylvania Coop. Wild1. Res. Unit Paper 101:1-13. Mimeo.

Sheidon, C.

1934. Studies on the life histories of Zapus and Napaeozapus in Nova Scotia. J. Mamm. 15(4):290-300.

1938. Vermont jumping mice of the genus Napaeozapus. J. Mamm. $19: 444-453$.

Short, H. L.

1961. Fall breeding activity of a young shrew. J. Mamm. 42(1):95.

Siegler, H. R.

1971. The status of wildcats in New Hampshire. P. 46-52. In Symposium on the native cats of North America. 36th N. A. Wild1. and Nat. Res. Conf. Portland, Oregon. 139 p.

Smith, N. B. and F. S. Barkalow, Jr.

1967. Precocious breeding in the gray squirrel. J. Mamm. 48(2):328-330. 
Snyder, D. P.

1956. Survival rates, longevity and population fluctuations in the white-footed mouse, Peromyscus Zeucopus, in southern Michigan. Univ. of Michigan Mus. Zool. Misc. Publ. 95:1-33.

Snyder, R. L. and J. J. Christian.

1960. Reproductive cycle and litter size of the woodchuck. Ecology $41(4): 647-656$.

Sollberger, D. E.

1940. Notes on the life history of the small eastern flying squirrel.

J. Mamm. 21(3):282-293.

1943. Notes on the breeding habits of the eastern flying squirrel (Glaucomys volans volans). J. Mamm. 24(2):163-173.

Spencer, A. W. and D. Pettus.

1966. Habitat preferences of five sympatric species of long-tailed shrews. Ecology 47(4):677-683.

Spencer, H. E., Jr.

1961. The black bear and its status in Maine. Augusta, Maine. Dept. of Inland Fisheries and Game, Bull. No. 4:1-55.

Stebler, A. M.

1951. The ecology of Michigan coyotes and wolves. Ph.D. diss., Univ. of Michigan. $198 \mathrm{p}$.

Storm, G. L.

1965. Movements and activities of foxes as determined by radio tracking. J. Wild1. Mgmt. 29(1):1-13.

Stuewer, F. W.

1942. Raccoons: Their habits and management in Michigan. Ecol. Monogr. 13(2):203-257.

Sullivan, E. G.

1956. Gray fox reproduction, denning, range and weights in Alabama. J. Mamm. 37:346-351. 
Svihla, A.

1930. Breeding habits and young of the red-backed mouse, Evotomys.

Papers Mich. Acad. Sci. Arts and Letters, 11:485-490.

1932. A comparative life history study of the mice of the genus

Peromyscus. Univ. of Michigan Mus. Zool. Misc. Publ. 24:1-39.

Taylor, W. P.

1956. The deer of North America. The white-tailed, mule and blacktailed deer, genus odocoileus, their history and management. Stackpole Co. and Wildl. Mgmt. Inst. $668 \mathrm{p}$.

Timm, R. M., L. R. Heaney and D. D. Baird.

1977. Natural history of rock voles (Microtus chrotorrhinus) in Minnesota. Canadian Field Nat. 91(2):177-181.

Uhlig, H. G.

1955. The gray squirrel: Its life history, ecology and population characteristics in West Virginia. Pittman-Robertson Project 31-R. West Virginia Conserv. Comm., Charleston, West Virginia.

Verts, B. J.

1967. The biology of the striped skunk. Univ. of I1linois Press, Urbana. $218 \mathrm{p}$.

Walker, E. P., F. Warnick, K. I. Lange, H. E. Vible, S. E. Hamlet, M. A. Davis and P. F. Wright.

1975. Mammals of the world. 2 vols. Johns Hopkins Univ. Press, Baltimore. $1500 \mathrm{p}$.

Whitaker, J. 0., Jr.

1963a. A study of the meadow jumping mouse, Zapus hudsonicus

Zimmerman, in central New York. Ecol. Monogr. 33(3):215:254.

1963b. Food, habitat and parasites of the woodland jumping mouse

in central New York. J. Mamm. 44(3):316-321.

1967. Hoary bat apparently hibernating in Indiana. J. Mamm. $48(4): 663$. 
Whitaker, J. 0., Jr.

1972a. Food habits of bats from Indiana. Canadian J. Zool. $50(6): 877-883$.

1972b. Zapus hudsonius. Amer. Soc. Mammalogists. Mammalian Species No. 11:1-7.

Whitaker, J. 0., Jr. and R. E. Mumford.

1972. Notes on occurrence and reproduction of bats in Indiana.

Proc. Indiana Acad. Sci. 81:376-383.

Whitaker, J. 0., Jr. and R. E. Wrigley.

1972. Napaeozapus insignis. Amer. Soc. Mammalogists. Mammalian Species No. 14:1-6.

Whitney, L. F. and A. B. Underwood.

1952. The raccoon. Orange, Conn. Practical Science Publ. Co.

Wimsatt, W. A.

1945. Notes on breeding behavior, pregnancy and parturition in some Vespertilionid bats of the eastern United States. J. Mamm. $26: 23-33$.

Wiseman, G. L. and G. O. Hendrickson.

1950. Notes on the life history and ecology of the opossum in southeast Iowa. J. Mamm. 31(3):331-337.

Wright, B. A.

1973. The cougar is alive and well in Massachusetts. Mass. Wildl. $24(4): 2-8,19$.

Wright, P. L.

1942. Delayed implantation in the long-tailed weasel (Mustela frenata), the short-tailed weasel (Mustela cicognani), and the marten (Martes americana). Anat. Record 83(3):341-353.

1948. Breeding habits of captive long-tailed weasels (Mustela frenata). Amer. Midland Nat. 39(2):338-344. 
Wright, P. L. and M. W. Coulter.

1967. Reproduction and growth in Maine fishers. J. Wildl.

Mgmt. $31(1): 70-86$.

Wrigley, R. E.

1972. Systematics and biology of the woodland jumping mouse,

Napaeozapus insignis. Illinois Biol. Monogr. 47. Univ. of

Chicago Press, Urbana. 117 p.

Wrigley, R. E., J. E. Dubois and H. W. R. Copeland.

1979. Habitat, abundance and distribution of six species of shrews in Manitoba. J. Mamm. 60(3):505-520.

Yahner, R. H.

1978. The adaptive nature of the social system and behavior in the eastern chipmunk, Tomias striatus. Beh. Ecol. and Sociobiol. 3:397-427.

Yates, T. L. and D. J. Schmidly.

1978. Scalopus aquaticus. Amer. Soc. Mammalogists. Mammalian Species No. 105:1-4.

Yerger, R. W.

1953. Home range, territoriality and populations of the chipmunk in central New York. J. Mamm. 34(4):448-458.

1955. Life history notes on the eastern chipmunk, Tomias striatus Zysteri Richardson, in central New York. Amer. Midland Nat. $53: 312-323$.

Young, S. P. and E. A. Goldman.

1946. The puma, mysterious American cat. Alierican Wildl. Inst., Washington, D. C. $358 \mathrm{p}$. 


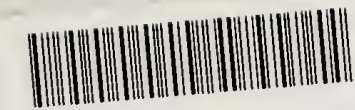 R0000 825450}

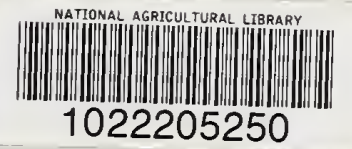



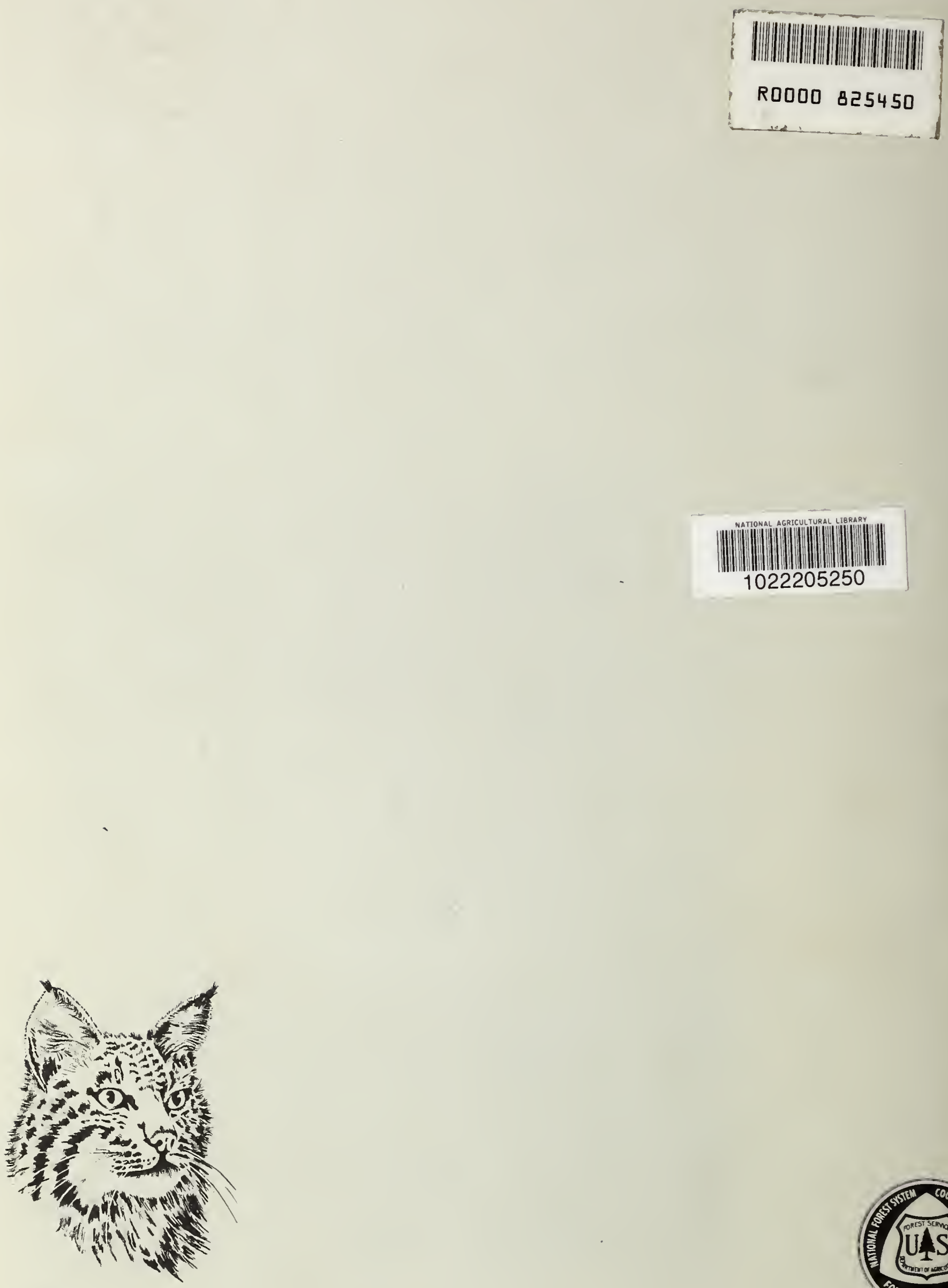